DEPARTMENT OF THE INTERIOR

UNITED STATES GEOLOGICAL SURVEY

CHARLES D. WALCOTT, DIRECTOR

\title{
CONTRIBUTIONS TO MINERALOGY
}

FROM THE

\section{UNITED STATES GEOLOGICAL SURVEY}

BY

F. W. CLARKE, W. F. HILLEBRAND, F. L. RANSOME, S. L. PENFIELD, WALDEMAR LINDGREN, GEORGE STEIGER, AND W. T. SCHALLER

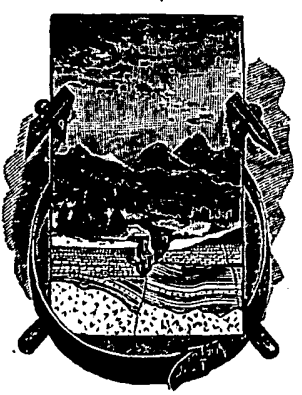

W A SHINGTON

GOVERNMENT PRINTING OFFICE

$1905^{\circ}$ 



\section{CONTENTS.}

Page.

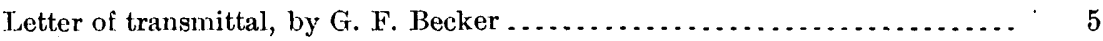

Prefatory note, by F. W. Clarke.............................. 7

On carnotite and associated vanadiferous minerals in western Colorado, by W. F. Hillebrand and F. Teslie Ransome

Some additions to the alunite-jarosite group of minerals, by W. F. Hillebrand

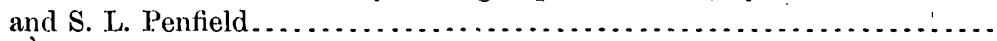
Minerals from the Clifton-Morenci district, Arizona, by Waldemar Lindgren

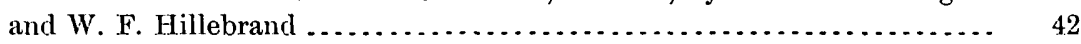

Two tellurium minerals from Colorado, by W. F. Hillebrand $\ldots \ldots \ldots \ldots \ldots \ldots \ldots$

Notes on lawsonite, by W. T. Schaller and W. F. Hillebrand . . . . . . . . . . 58

The composition of yttrialite, with a criticism of the formula assigned to

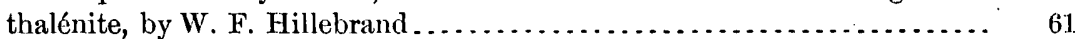

A pseudo-serpentine from Stevens County, Wash., by F. W. Clarke........ 69

On "californite," by F. W. Clarke and George Steiger .................. 72

The action of silver nitrate and thallous nitrate upon certain natural silicates,

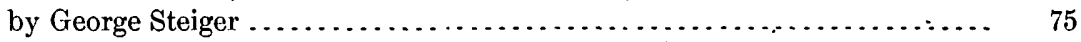

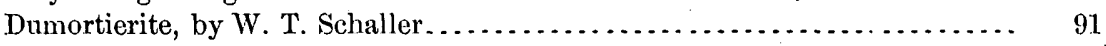

Mineralogical notes, by W. T. Schaller..........................

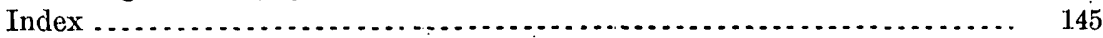




\section{IJLUSTRATIONS.}

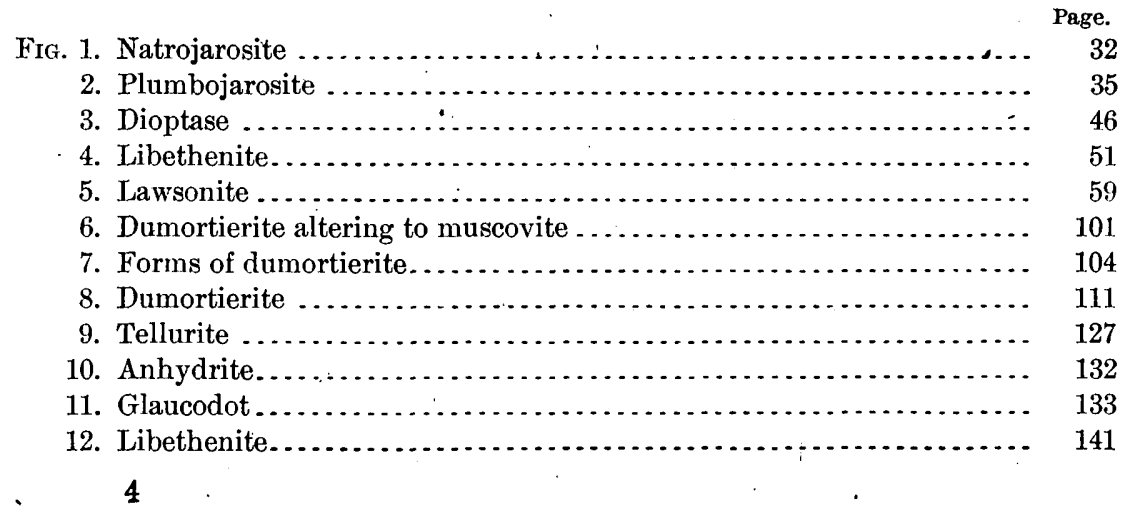




\title{
LETTER OF TRANSMITTAL。
}

\author{
Department of the Interior, \\ United States Geological Surver, \\ Washington, D. C., January 31, 1905.
}

SIR: I have the honor to transmit herewith a series of papers by various hands for publication as a bulletin. They represent mineralogical investigations incidental to geological researches and important to the progress of geology, and are here brought together for convenience of reference.

Very respectfully,

G. F. BECKER,

\section{Geologist in Charge Division of \\ Chemical and Physical Research.}

Hon. Charles D. Walcott,

Director United States Geological Survey. 



\title{
CONTRIBUTIONS TO MINERALOGY FROM THE UNITED STATES GEOLOGICAL SURVEY.
}

\author{
PREFA'TORY NO'TE.
}

By F. W. Clarke.

Although mineralogical research occupies a relatively small place among the many varied activities of the United States Geological Survey, it is by no means neglected. From time to time interesting material is collected by the field parties of the organization, and specimens deserving study are received from other sources. These are worked up, as opportunity offers, in the chemical laboratory of the Survey, sometimes independently and sometimes, as in the work reported in two of the memoirs here presented, in cooperation with the geologists by whom they were brought in. Occasionally assistance is received from investigators not connected with the Survey, and one such case is now represented by the joint paper of Doctor Hillebrand and Professor Penfield, of Yale University. In that instance the chemical work was done in Washington and the crystallographic measurements were made at New Haven.

Most of the papers contained in this bulletin represent investigations which are complete within themselves. The work done by $\mathrm{Mr}$. Steiger upon the silver and thallium derivatives of the zeolites, however, is to be regarded as one part of a series of researches upon the constitution of the silicates. Some parts of this series have been already published, and it is hoped that this work may be continued in the future. The field to be covered is enormous and progress within it is necessarily slow. Still, the results obtained so far are definite and significant, especially as they show a chemical plasticity among the silicates which was formerly unsuspected.

Some of the items of more than ordinary interest to be found within these pages are as follows: Three new mineral species-morencite, coronadite, and plumbojarosite-are described. Natrojarosite, 
although not' absolutely new, is now thoroughly established as a definite mineral. The true character of carnotite is shown in Doctor Hillebrand's research, and the same chemist has worked out more. fully than his predecessors the composition of yttrialite and its relations to other species. Mr. Schaller's very complete study of dumortierite is also worthy of especial mention, and his notes upon other minerals from California are but the first fruits of a much larger research which is already well under way. 


\section{ON CARNOTITE AND ASSOCIATED VANADIFEROUS MINERALS IN WESTERN COLORADO.}

By W. F. Hillebrand and F. L. Ransome.

\section{INTRODUCTION.}

By W. F. Hillebrani).

The rather widespread occurrence in western Colorado of considerable quantities of a canary-yellow ore of uranium has been known for a few years past. It has been marketed to the extent of a few tons, but its mineralogical nature was unknown or incorrectly surmised until 1899.

In the spring of that year a specimen of this ore first reached my hands through Dr. George P. Merrill, of the United States National Museum, and ras soon found to contain a mineral or minerals new to science. Within a week appeared the announcement by MM. C. Friedel and E. Cumenge ${ }^{t}$ of a new mineral, carnotite, a hydrous vanadate of uranium and potassium, obtained through $\mathrm{Mr}$. Poulot of Denver, from Roc Creek, Montrose County, Colo. Mr. Poulot had already identified vanadium in it. It was at once seen, despite certain differences in composition, that the two were identical.

According to the French authors the mineral is of simple composition, as above expressed, with only a little iron and mere traces of $\mathrm{Al}, \mathrm{Ba}, \mathrm{Cu}, \mathrm{Pb}$, and also, according to $\mathrm{M}$. and Mme. Curie, of the radio-active substances radium and polonium. The empirical formula $2 \mathrm{U}_{2} \mathrm{O}_{3}, \mathrm{~V}_{2} \mathrm{O}_{5}, \mathrm{~K}_{2} \mathrm{O}, 3 \mathrm{H}_{2} \mathrm{O}$, was assigned to it, some doubt attaching to the water.

Since then $I$ have been able to examine carnotite from several localities in western Colorado, finding in each case the same lack of agreement with the analyses of Friedel and Cumenge.

While I was engaged in this work my attention was called to certain more or less greenish sandstones from the vicinity of Placerville on the San Miguel River, San Miguel County, Colo., which were said to be highly vanadiferous and of considerable extent, and in which a zone

a Bull. Soc. Chim. de Paris (3), xxi, 328, 1899; Bull. Soc. Franc. Min., xxii, 26, 1899; Comptes Rendus, cxxviii, 532, 1899; Chemical News, $1 \times x x, 16,1899$. The papers as published in French differ slightly. 
a few inches thick was rather strongly impregnated with a yellow mineral resembling and probably identical with carnotite. This mineral appeared also scattered through the sandstone at other points in sporadic small patches, sometimes visible only by aid of a lens.

This occurrence led to the thought that the carnotite bodies farther west might also be associated with existing or dependent on preexistent vanadiferous sandstones. For the carnotite of Montrose and Mesa counties, as is stated by the French authors, occur's mixed in all proportions with quartz-sand grains, the remnants, beyond doubt, of former sandstone bodies, and it was soon recognized that in the carnotite bodies the vanadium existed in two conditions, the larger part by far as pentavalent vanadium in the easily soluble carnotite, and a smaller and sometimes hardly distinguishable portion as trivalent vanadium in a much less soluble silicate which was free from uranium.

It was hoped that, by a field reconnaissance, observations bearing on these points wouid be obtained and material assembled which would on analysis help to determine the nature and explain the association of these two entirely different classes of mineral substances.

The field and microscopical observations of Messrs. Ransome and Spencer are embodied in the pages immediately following these introductory remarks. Unfortunately their collections, except those from Placerville, came to hand so late that the chemical work on the more western occurrences has been confined to the carnotite bodies alone, specimens of which were already in my hands. Greenish sandstones have been observed by Messrs. Ransome and Spencer in those regions, but whether any of them are highly vanadiferous, or what their connection with the carnotite may be, remains yet unknown. The only two examined did not owe their color to vanadium. Meanwhile the chemical results thus far obtained will be found in the.concluding section of this paper.

In this place it is my pleasure to record my appreciation of the readiness with which the following gentlemen have supplied me with material for study: Messrs. Poulot and Voillequé of Denver, Mr. A. B. Frenzel of Placerville, and Mr. J. R. Duling of Paradox. These gentlemen have also not hesitated to give me all information at their disposal as to cccurrence and field relations of these interesting ore bodies.

\section{OCCURRENCE OF THE URANIUM AND VANADIUM ORES.}

\section{By F. L. Ransome. \\ GENERAL STATEMENT.}

In the autumn of 1899 , accompanied by Dr. A. C. Spencer, whose knowledge of the stratigraphy of the region was of great assistance, I made a hasty reconnaissance trip into the western portions of San Miguel, Montrose, and Mesa counties, near the Utah-Colorado 
line. The primary object of the expedition, in accordance with a suggestion from Mr. S. F. Emmons, was to investigate the copper deposits of La Sal Creek, Paradox and Sinbad valleys, and the vicinity, which had been the occasion of some mining excitement a few months before. A memorandum from Dr. W. F. Hillebrand, received just before starting, indicated that it would be well also to examine certain prospects on which some preliminary work had been done, looking toward the extraction of ores of uranium and vanadium. It is to these ores that the present notes are confined.

The most convenient way of reaching Paradox Valley was found to be the stage road, which, starting from Placerville, a settlement and station on the Rio Grande Southern Railroad, runs by way of Norwood, Shenandoah, and Naturita to Paradox, a distance of 60 or 70 miles. The region can also be reached from the west by way of Moab, in Utah.

The topography of the region west of Placerville is that characteristic of the "mesa country" of western Colorado and southeastern Utah. Broad stretches of plateau are intersected by steep-walled canyons and cliff-encircled valleys. The underlying rocks comprise the "Red Beds" of the Dolores formation " (Triassic), the La Plata formation (Jurassic), the McElmo formation (Jurassic), the Dakota sandstone (Cretaceous), and the Mancos shales (Cretaceous). Carboniferous rocks occur in Sinbad Valley, and a series of gypsum-bearing shales of unknown age is found in the bottoms of Sinbad and Paradox valleys, but as the ore deposits to be described all occur in the beds of the La Plata and McElmo formations, these older rocks need not again be referred to. The sediments making up these various formations lie usually nearly horizontal, but they are sometimes flexed and frequently faulted.

In all of the prospects examined the ore of uranium occurs in the form of the recently described bright-yellow carnotite. In one case this is intimately associated with a dull olive-green mineral which, according to Doctor Hillebrand, is either identical with, or very closely allied to, the vanadium-mica roscoelite. Deposits of one or both of these minerals occur widely scattered over San Miguel and Montrose counties, Colo., and in the Blue Mountain (Sierra Abajo) district of southeastern Utah; but only a few of the known deposits were personally examined.

\section{PLACERVILLE DEPOSITS.}

These are essentially vanadium deposits, and occur 4,500 feet nearly northeast of the railway station near Placerville, and about 1,000 feet above the San Miguel River. The lower 900 feet of the San Miguel

aThe formation names used in these notes are those adopted by Mr. Whitman Cross in the text of the Telluride folio (folio 57), of the U. S. Geological Survey. The reader is referred to this folio for fuller descriptions. 
canyon is cut in the characteristic "Red Beds" of the Dolores formation. Above the Dolores comes the La Plata sandstone in typical development, as described in the Telluride folio, viz, two heavy beds of lightcolored sandstone, separated by a much thinner bed of dark limestone. The roscoelite occurs as an impregnation in the lower bed of the La Plata sandstone, about 100 feet above the base, and just beneath the bed of dark limestone. All the beds at this point are practically horizontal. The dark green vanadiferous sandstone occurs in a nearly continuous band, approximately parallel to the bedding planes, and varying in thickness from a few inches up to 5 or 6 feet. This band extends along the sundstone cliffs for an estimated distance of about 2,000 feet. The roscoelite more or less thoroughly impregnates portions of the fine-grained sandstone which constitutes the mass of the bed. It sometimes makes up more than 20 per cent of the vanadif-. erous facies. Normally the sandstone of this lower bed of the La Plata is light buff in color, with patches, mottlings, and stripes of pale pink, the latter color being apparently due to small amounts of ferric oxide. But when richly impregnated with roscoelite this light-colored sandstone becomes dark olive-green, the contrast being most marked when the cliffs are wet. Although fairly continuous for the distance stated, this zone of vanadiferous sandstone is by no means regular. It varies much in thickness, and in one place splits into two or more branches. At some points two or more distinct streaks of roscoelitebearing sand were found at different horizons in the main sandstone bed. The carnotite is not nearly so abundant as the roscoelite at this locality. It occurs as minute yellow specks in the sandstone, and particularly as thin horizontal seams or streaks near the bottom of the vanadiferous zone.

The work thus far done on the several claims which have been located along these deposits is of the most superficial character. On the Canary claim Mr. A. B. Frenzel has run a tunnel, about 18 feet long, which exposes a typical section of the impregnated zone. The roof of the tunnel is formed by the under side of the bed of dark limestone previously referred to. This limestone is underlain by a few inches of sandy limestone which passes into the light-buff La Plata sandstone without break. The latter contains abundant calcite as a cement or matrix for the sand grains. At a distance of a foot below the limestone, the sandstone shows, on close inspection, numerous specks of carnotite and gives a qualitative reaction for vanadium (Hillebrand). Examined in thin section under the microscope, this portion of the bed shows a fine-grained homogeneous sandstone, in which well-rounded grains of quartz are held together by a rather abundant matrix of calcite. The calcite is crystallized as a fine granular aggregate and includes small indeterminable particles of various kinds. Many of the quartz grains, as seen in section, are entirely surrounded by calcite, and so isolated from adjacent grains. A pale 
lemon-yellow substance occurs sporadically in the section as an interstitial material between the quartz grains. This is probably the carnotite, which was seen as small, yellow specks in the hand specimen. It is very minutely crystalline, recalling the habit of some obscure chloritic aggregates in decomposed igneous rocks, and is too indistinct for successful optical study. Small crystal grains of zircon are scattered through the sandstone, and are readily concentrated in the residue after treating with hydrofluoric acid.

Within the next 2 feet below the zone where it exhibits the foregoing facies, the sandstone becomes pinkish in consequence of the presence of ferric oxide, and in this pinkish rock the lens fails to reveal any roscoelite or carnotite. But just below the pink zone the sandstone begins to show yellow and green specks. The latter especially become more numerous and larger, until at from 3 to 4 feet below the limestone the sandstone has a decided green tint. Farther downward this deepens, until near the floor of the tunnel the sandstone is a uniform deep olive-green. This green rock is rich in roscoelite (over 20 per cent) and shows many small yellow specks of carnotite. This is regarded as the first-class ore, and the chief value of the deposit is supposed to be in its vanadium, the uranium being very subordinate. In this respect the Placerville deposit differs from those on La Sal and Roc creeks, presently to be described, where the mineral sought for and occurring most abundantly is carnotite.

Thin sections of the green-spotted sandstone, when examined microscopically, resemble those of the light-buff sandstone just above it, as far as character of quartz grains and relative abundance of matrix are concerned. But the character of the matrix or cement is different. Calcite is much less abundant and its place is largely taken by roscoelite. This is grass-green in thin section, and might readily be mistaken for indistinct wisps and areas of chlorite. It sometimes forms a distinct envelope around the quartz grains, showing an indistinct foliated or fibrous structure, with the fibers normal to the surface of the grains.

The uniformly dark-green sandstone, richest in roscoelite, does not effervesce with acids and shows no calcite cement in thin section. The usual quartz grains are held together by roscoelite. This is crystalline, but the highest available powers show only an indistinct and minute foliation, such as may be observed in some very finely crystallized chlorites.

Close to the floor of the tunnel is a fairly regular, nearly horizontal streak of carnotite, varying in width, but usually less than an inch wide, and showing noticeable diminution in thickness in the face of the tunnel. This small seam is not solid carnotite, but is merely a zone in the sandstone impregnated with the bright-yellow uranium mineral. It is not nearly so continuous as the main vanadiferous belt, and was seen only at three or four places along the outcrop of the 
belt, which extends for a distance of about 2,000 feet. When this seam is closely examined it is seen that narrow bands rich in carnotite alternate with. green bands carrying mostly roscoelite. 'There is also usually present a seam of almost pure quartz, generally about an eighth of an inch in thickness, though often thicker. The microscope shows it to be a true quartzite, in which the original rounded detrital grains of quartz have been cemented by fresh quartz in optical continuity with the older granules. A similar quartzite occurs in the green vanadiferous sandstone above the carnotite, where it forms concretionary knots and nodules. It was not noted in the buff sandstone, however, where the cementing material is calcite.

Immediately below the carnotite seam there is a parting or "floor" in the sandstone, probably originally a very thin layer of shale, which forms the working floor of the tunnel. The sandstone below this floor is plainly impregnated for a short distance with roscoelite, but the thin shale seam is regarded as the practical bottom of the deposit.

The questions of the origin and actual extent of this deposit are closely related and are of much interest. Their discussion will be deferred until the other deposits visited have been described.

Some distance below the Placerville vanadium deposit a zone of green sandstone, presumably belonging to the Dolores formation, was observed. This color is a somewhat brighter green than that of the vanadiferous sandstone higher up the slope. As there are some copper prospects near by, from which ore has been taken, this was supposed to be a copper stain. Qualitative tests by Doctor Hillebrand show, however, that the color is due to a compound of chromium.

Similar green sandstones occur on the western side of Sinbad Valley in what is apparently the La Plata formation, and were originally supposed to be impregnated with roscoelite. Doctor Hillebrand's investigations, however, show that they too owe their color to some chromium mineral. These occurrences are interesting as showing that a green color in sandstones may result from various causes, and that even a bright green tint can not be taken as an infallible indication of copper.

\section{LA SAL CREEK DEPOSITS.}

These occur in the extreme western portion of Montrose County, southwest of Paradox, and about 6 miles up La Sal Creek from Cashin. They are reached by trails from Paradox Valley and from Cashin. The deposits are on the south side of La Sal Creek and about 700 feet above the stream. They occur for a distance estimated at more than a quarter of a mile, along the sandstone cliffs which descend from the mesa into the canyon of La Sal Creek, and only a few feet below the level of the mesa surface.

In the absence of continuous stratigraphic work, it is impossible to correlate certainly and finally the rocks on La Sal Creek with the divisions established by Cross and Spencer in the Telluride quadrangle, 
which lies just east of this area. It seems probahle, however, that the La Plata sandstone attains a much greater thickness in this portion of western Colorado than it does between Telluride and Placerville. The limestone bed, so characteristic a feature of the formation near Placerville and farther east, is not uniformly present in this western region, and the La Plata sandstone (Variegated beds, in part, of the Hayden survey) is not always readily differentiated from the underlying Dolores formation (Red Beds). For a vertical distance of about 400 feet above the bed of La Sal Creek the rock is a heavy-bedded, rather fine-grained, light-colored sandstone, which is considered by Doctor Spencer to be the La Plata. Above this come thinner-bedded sandstones, with some conglomerates and shales, which are included in the

- McElmo formation. It is in this upper series that the uraniferous deposits occur. All the beds are here approximately horizontal.

As revealed by numerous small openings near the crest of the bluff, the carnotite, which is the material here sought, is found chiefly in a massive bed of nearly white sandstone. Some of the ore, however, lies between the sandstone and a lower bed of light-gray shale. Although the prospecting openings all lie at about the same level along the cliffs, the deposit is not nearly so regular as the vanadiferous band near Placerville.

The carnotite of La Sal Creek occurs as irregular, bunchy "pockets" in the sandstone, or along the contact of the sandstone with the underlying shale. These have all the appearance of being impregnation deposits, the solutions carrying the uranium compounds having deposited the ore wherever they found ready passage through the rock-usually along bedding planes. No roscoelite was seen with the carnotite.

The most remarkable and interesting fact in regard to the La Sal Creek deposits is their very superficial character: The ore bodies are usually flat-lying streaks, a few inches thick, which grade above and below into the common light-buff sandstone, and which die out and disappear when followed into the hillside. In tunnels that run but a few feet underground the yellow impregnation of carnotite can be seen gradually to die out and to be succeeded by light-colored sandstone, showing no trace of the mineral. It is doubtful whether any appreciable quantity of carnotite occurs as much as 20 feet from the surface, on any of the locations, although this distance is given from memory and not from measurements on the ground. As before stated, the impregnation has usually taken place along bedding planes; it has also proceeded along surfaces of minor and superficial movement in the rocks. In one case it was observed that a portion of the overlying sandstone had moved upon the underlying shales, the disturbance being apparently a superficial one, of a kind commonly enough observed where massive beds rest on yielding shales on a steep hillside. In other words, the movement appeared to be directly related to the present topography. The carnotite was here deposited subsequent to 
the movement and had filled the small openings and dislocations in the shale caused by this very recent disturbance. It was reported that some of the best nests of ore had been found in "slide rock," i. e., rock which had slipped to some extent down the slope; but I was unable to verify this statement further than is indicated in the preceding description. There can be little doubt that the deposits of carnotite on La Sal Creek are not only very superficial in character but very recent in age.

\section{ROC CREEK DEPOSIT.}

The principal claim is the Copper Prince, owned by J. R. Duling, on the north side of Roc Creek, 3 or 4 miles above its mouth, and near the foot of the Miller trail to Paradox. It is reached by this trail from Paradox Valley, or by trail from Hydraulic on the Dolores River. This deposit is in the La Plata sandstone, according to Doctor Spencer's observations, and has been more extensively exploited than any other seen. The sandstone, which at this point is nearly horizontal, is cut by an east-west fault, the fault plane dipping north at about $70^{\circ}$. The amount and character of the throw could not be determined. It is probably less than 50 feet. The carnotite occurs in the hanging wall of the fissure as small irregular branches in a loose mass of crushed sandstone and also as an impregnation of some of the firmer portions of the bed. No roscoelite was seen. Several small tunnels have been run in on the hanging wall side of the fissure (which itself carries no vein or ore-body), but they had been securely closed by planking, and no examination of their inner ends could be made. I am thus unable to tell what changes the deposit would show if it could be followed inward from the surface. A few hundred pounds of picked carnotite ore has been shipped from this claim and is reported to have sold for $\$ 1.25$ a pound in Denver. This deposit is similar in character to others examined, except that in this case a well-defined fault has provided a zone of crushed and porous rock in the hanging wall, along which impregnation could take place. A few hundred feet farther west the crushed sandstone adjoining the fault has been impregnated with cupriferous solutions and is spotted with stains of the blue and green carbonates of copper.

\section{OTHER DEPOSITS.}

It is known that several carnotite claims have been located in Gypsum Valley in what is known as the Disappointment district. The impregnated sandstone is said to cap a hill and to constitute an extensive deposit, but it was not visited. Carnotite is also reported from the Blue Mountain district, but I have no personal knowledge of these occurrences. It seems highly probable that the material will be found widely distributed in the Mesozoic sandstones of western Colorado and eastern Utah, although perhaps nowbere in very extensive bodies. 


\section{ORIGIN OF THE DEPOSITS.}

That the bodies of carnotite and roscoelite were formed subsequently to the deposition of the sandstones is evident from the facts presented in the preceding pages. It is equally plain that the minerals could not have resulted from the alteration, in place, of other compounds of vanadium and uranium originally contained in the sands. The shape and position of the deposits indicate clearly that the ores have been brought to their present position by transportation. Moreover, the recency of the deposits and the fact that they are sometimes directly connected with faults and dislocations in the sandstones show that the vanadium and uranium compounds could not have been the original cementing material of the quartz grains, but in all probability they have locally replaced the calcite that acts as matrix to the ordinary light-colored sandstone in which the ore bodies occur. The deposits of roscoelite appear to be comparable to impregnations formed in sandstones by cuprifęrous solutions-such impregnations as may be seen at many places in this region, particularly on La Sal Creek near Cashin and in Sinbad Valley-whereby the sandstone becomes colored bright green with carbonate of copper. In these places, however, the copper appears to have been previously deposited in part as chalcocite. An analogy might also be drawn with the green chromiferous sandstone near Placerville, already referred to. In all these cases the actual sources of the materials which have been deposited by solutions in their present position are not known. Doctor Hillebrand has shown, ${ }^{a}$ however, that vanadium in small amounts is widely distributed in sandstones, limestones, and igneous rocks. : It is perhaps present in very small amounts throughout the sandstone, and the deposits described may simply represent a concentration of this material under certain favorable conditions of solution and redeposition.

In the absence of exploitation it is manifestly impossible to predict the probable shape and size of ore bodies formed in this manner. The roscoelite seen near Placerville appears, however, to be much more persiste at than the carnotite. There is no apparent reason why a mass of sandstone, impregnated with roscoelite, which is continuously exposed for several hundred feet along a cliff, should not extend for a considerable distance inward from the cliff face. The carnotite, on the other hand, appears to be of much more superficial occurrence, and its connection with the present surface of the ground is not yet fully understood. This would indicate that the carnotite results from a local concentration of material already existent in the sandstone, and the deposition of this material in the form of carnotite under conditions determined by proximity to the surface, and probably partly dependent upon a semiarid climate. 


\section{CHEMICAT ANALYSES AND DISCUSSION.}

By W. F. Hillebrand.

\section{GREEN COLORING CONSTITUENT OF PLACERVILLE SANDSTONE.}

As noted by Doctor Ransome, the greener the sandstone the greater has been the replacement of the calcareous cementing material by the crystalline vanadiferous mineral. Fortunately, the greenest available specimen was entirely free from carbonate, and this was used for analysis, 10 grams being taken for the main portion.

The green substance was but slightly attacked by cold acids and not rapidly by hot ones, nevertheless after from twelve to twenty-four hours' digestion on the water bath with diluted nitric acid the greenish color had been transferred to the liquid, the residue of sand was nearly white, and a rather voluminous separation of nongelatinous silica had taken place. The filtration and washing of the insoluble matter was accomplished without difficulty. The free silica in it was extracted by two or three digestions of fifteen minutes each on the water bath with sodium carbonate solution of 5 per cent strength. The flocculent matter had entirely disappeared and the sandy residue was collected in a Gooch crucible and washed with hot sodium carbonate solution, followed by very dilute nitric acid, and finally by alcohol, to prevent turbid filtration. Drying of the sand was effected by allowing the pump to draw air through the crucible until no further loss in weight resulted.

The water in the sand was then determined at $105^{\circ}$, at $300^{\circ}$, and above $300^{\circ}$. Similar water determinations having been made on the unattacked substance, the differences gave the water expelled at those temperatures from the soluble part.

The sodium carbonate solution was acidified, evaporated, and filtered, and the filtrate again evaporated, to recover the last of the silica. To this was added a very small portion which the nitric-acid extract of the sandstone held in solution. The sum represents the total silica of the decomposed portion of the sandstone.

The further analysis of the nitric solution presented difficulty - because of the vanadium it contained. It was carried out in a variety of ways, of which the following seemed to be most satisfactory:

Barium was first precipitated by sulphuric acid and subsequently separated from traces of lead, calcium, and vanadium. Hydrogen sulphide then threw out further traces of lead and copper with much sulphur from reduction of $\mathrm{V}_{2} \mathrm{O}_{5}$ to $\mathrm{V}_{2} \mathrm{O}_{4}$. After evaporation of the filtrate to reoxidize vanadium and iron, the alumina, iron, and trace of uranium with much vanadium were separted from the calcium, magnesium, and alkalies by three precipitations by ammonia solution. The combined filtrates were evaporated and ignited, the residue was transferred to a porcelain boat with nitric acid, evaporated therein to complete dryness, and exposed in a glass tube to a current of dry 
hydrochloric-acid gas, as recommended by Smith and Hibbs ${ }^{a}$ for the expulsion of vanadium from alkaline vanadates. The removal of vanadium being incomplete, the contents of the boat were again evaporated with nitric acid and again distilled, and these operations were repated till no further evidence of a brown distilate appeared. The boat now contained only magnesium and alkalies with a little calcium. The distillates, containing all the vanadium that was in the boat, had been collected in U-tubes charged with water, and were eventually obtained in sulphuric solution for further treatment by evaporating with sulphuric acid in porcelain.

The precipitate of $\mathrm{Al}_{2} \mathrm{O}_{3}$, etc., was dissolved in nitric acid, evaporated almost to dryness in platinum, and boiled with sodium-hydroxide solution. These operations were repeated on the precipitate after filtration. The iron and titanium thus purified were redissolved, precipitated by ammonia, weighed, redissolved by acid potassium sulphate, and the ferric iron was reduced by hydrogen sulphide and titrated with permanganate after boiling out the reducing agent. The titanium was then found colorimetrically by hydrogen peroxide.

The combined alkaline filtrates were heated with excess of ammonium nitrate to separate alumina from most of the vanadium. The precipitate was redissolved in nitric acid, reprecipitated by ammonia, then ignited and weighed and redissolved by acid potassium sulphate. The sulphuric solution was reduced by hydrogen sulphide, boiled and filtered from platinum sulphide, again boiled in a current of carbon dioxide, and titrated hot with permanganate. Sulphur dioxide gas was then introduced, boiled out in a current of carbon dioxide, and the titration repeated, this second result being taken as representing the $\mathrm{V}_{2} \mathrm{O}_{4}$ equivalent to the $\mathrm{V}_{2} \mathrm{O}_{5}$ that still contaminated the $\mathrm{Al}_{2} \mathrm{O}_{3}$. Deducting the $\mathrm{V}_{2} \mathrm{O}_{5}$ thus found from the combined weight of $\mathrm{Al}_{2} \mathrm{O}_{3}$ and $\mathrm{V}_{2} \mathrm{O}_{5}$ gave the $\mathrm{Al}_{2} \mathrm{O}_{3}$ of the soluble constituent of the sandstone.

The combined filtrates from the alumina were evaporated and ignited to remove ammoniacal salts; the residue was converted to sulphates and united with the earlier solution of vanadium sulphate. The vanadium in it was then determined precisely in the manner already described, and when added to that found with the alumina and calculated to $\mathrm{V}_{2} \mathrm{O}_{3}$ gave the total in the sandstone.

A check was made by dissolving the sandstone in hydrofluoric and sulphuric acids in a current of carbon dioxide and titrating the $\mathrm{V}_{2} \Theta_{3}$ with permanganate. The figure thus obtained was a trifle below that found as above detailed, and this is to be attributed to the presence of a very little vanadium as $\mathrm{V}_{2} \mathrm{O}_{5}$ in carnotite, and probably as a lead vanadate. All the uranium and most of the trifling amount of lead could be extracted by cold dilute nitric acid, showing that they were foreign to the green substance. 
It is preferable to regard iron as in the ferric rather than the ferrous state; otherwise an equivalent amount of vanadium would have to be considered as $\mathrm{V}_{2} \mathrm{O}_{5}$, for which there is no occasion. It is quite possible that the iron is in part, if not wholly, foreign to the green matter, for it would be surprising to find an exposed sandstone free from ferric oxide.

If the iron is disregarded as probably extraneous, the ratios given below afford the following empirical formula:

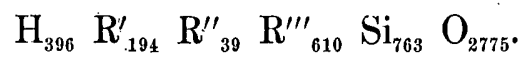

$$
\begin{aligned}
& \text { or, } \mathrm{H}_{396} \mathrm{R}_{104}^{\prime} \mathrm{R}_{39}^{\prime \prime} \mathrm{R}^{\prime \prime \prime}{ }_{610}\left(\mathrm{SiO}_{4}\right)_{555}\left(\mathrm{Si}_{3} \mathrm{O}_{8}\right)_{69} \text {. }
\end{aligned}
$$

Simplified, this is $\mathrm{H}_{40} \cdot \mathrm{R}^{\prime}{ }_{20} \mathrm{R}_{4}^{\prime \prime} \mathrm{R}_{{ }_{61}^{\prime \prime}} \mathrm{X}_{62.4} \cdot$

In view of the fact that the mineral is probably not perfectly pure and of the uncertainties affecting the amount of water to be considered, etc., the above affords a close approach to the typical phengitic muscovite formula, $\mathrm{H}_{2} \mathrm{KR}^{\prime \prime \prime}{ }_{3} \mathrm{X}_{3}$, in which $\mathrm{X}$ comprises the groups $\mathrm{SiO}_{4}$ and $\mathrm{Si}_{3} \mathrm{O}_{8}$.

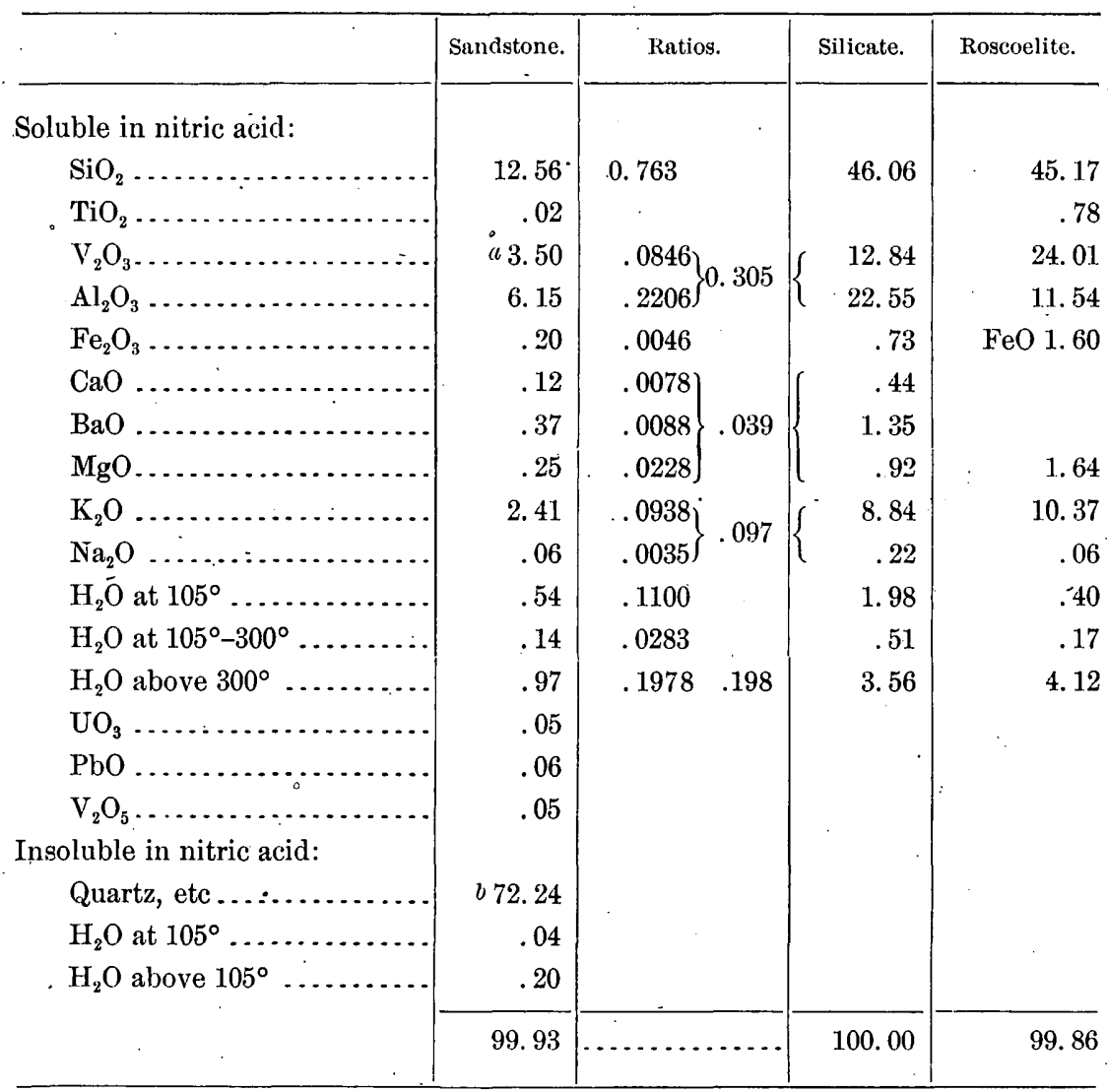

$a$ Oxidation by permanganate of the $\mathrm{HFl}$ and $\mathrm{H}_{2} \mathrm{SO}_{4}$ solution of the sandstone indicated 3.43 per cent $\mathrm{V}_{2} \mathrm{O}_{3}$ (mean of $3.50,3.32,3.48,3.43$ ).

$b$ Containing about 65 per cent $\mathrm{SiO}_{2}, 7$ per cent $\mathrm{Al}_{2} \mathrm{O}_{3}\left(\mathrm{Fe}_{2} \mathrm{O}_{3} \mathrm{TiO}_{2}\right)$ and about 0.3 per cent of zircon and other minerals not decomposed by repeated evaporations with $\mathrm{HFl}$ and $\mathrm{H}_{2} \mathrm{SO}_{4}$.

Traces of $\mathrm{Li}, \mathrm{Cu}, \mathrm{Mo}, \mathrm{Bi}$. No $\mathrm{Cl}, \mathrm{SO}_{3}$, or $\mathrm{P}_{2} \mathrm{O}_{5}$. 
An attempt to satisfactorily distribute the constituents among different chemical molecules would be futile, since, for instance, we do not know whether to ascribe the barium to a biotite or muscovite molecule, but the chose approach to the muscovite ratio leaves little room to doubt the character of the body. Notwithstanding the chloritic aspect of the mineral under the microscope, the analysis shows that it can not be a chlorite, and we have undoubtedly to do with a body closely related to the mica roscoelite, wherein, however, the percentage proportions of $\mathrm{Al}_{2} \mathrm{O}_{3}$ and $\mathrm{V}_{2} \mathrm{O}_{3}$ are reversed; thus affording a further striking example of the mutual replaceability of these two oxides.

For comparison, the latest analysis of roscoelite from Placerville, Cal., is included in the above table. Peculiar, though unimportant, is the coincidence that the only two known localities for this mineral should bear the name Placerville.

\section{GREEN SANDSTONE COLORED BY CHROMIUM.}

Other sandstones that were a much brighter green than the vanadiferous one were observed and collected by Doctor Ransome, both at Placerville and 60 miles distant in Sinbad Valley. The color suggested a salt of copper as its cause, but analysis showed it to be due to chromium. Time has not been found to determine the nature of this coloring body. It is very difficultly soluble, and thus presents greater hindrance to analysis than did the vanadium compound. It would be interesting to find that it is a micaceous mineral analogous to the one just described. Under the microscope it presents a chloritic appearance (Ransome). If opportunity offers, the problem of its nature may yet be attacked.

In still another greenish sandstone from the west bank of the Dolores River, near the mouth of La Sal Creek, analysis failed to show either vanadium or chromium.

\section{CARNOTITE ORES.}

\section{OPTICAL EXAMINATION.}

Dr. George P. Merrill has kindly submitted the following notes: .

The carnotite powder appears under the microscope in the form of exceedingly minute dust-like particles without crystal outlines and acting so faintly on polarized light as to at first seem almost amorphous. Much of the matter appears merely as a fine brownish clay, stained yellow by an amorphous pigment, but occasionally a well-defined fragment of a light-yellow translucent mineral is seen, which doubtless represents the vanadium compound in its condition of ideal purity.

Working over a considerable amount of the powder I have found occasional clusters of this yellow mineral in the form of flattened radiating crystals with pyramidal terminations which are without evident pleochroism, polarize only in dull colors, and give extinctions always parallel to the axis of elongation. These are so minute (not over $0.25 \mathrm{~mm}$. in length) and so thin that $I$. have never been able to find a crystal so oriented as to give an opportunity of determining its exact character, and I can only say that the general shape is such as to suggest a hexagonal mineral, though this is by no means certain. 


\section{CHEMICAL EXAMINATION OF CARNOTITE ORES.}

The chemical problems involved in the analysis of the carnotite ores were peculiarly intricate. Ideal material was quite unobtainable and mechanical separation was impossible. The first specimen received happened to be of higher grade than any of the subsequent ones, containing about 5 per cent of sand grains and showing only very faint delicate reddish tracings, indicative of some foreign iron mineral. In mass it was of a beautiful canary-yellow color and easily broken down by pressure. Other specimens were more coherent, the degree depending altogether on the extent to which the sandstone had been impregnated and altered, and they sometimes showed more of the peculiar reddish admixture.

A fact only suspected in making the first analysis was confirmed by subsequent work on lower-grade ores, namely, that the vanadium existed in two conditions, in entirely distinct minerals, the greater part by far as pentavalent vanadium in the easily soluble carnotite, and a smaller, much less soluble portion, almost vanishing in the purest ores, in the trivalent state as a constituent of a silicate free from uranium. This observation explained the statement of Messrs. Poulot and Voillequé that they had found the low-grade ores relatively richer in vanadium, as compared with uranium, than the high-grade ores.

While the carnotite dissolves at once in cold dilute nitric acid, unfortunately the vanadiferous silicate is not quite insoluble, hence arose an important difficulty in the way of arriving at the true composition of the carnotite. It is true that in one case the silicate has been analyzed (p. 30), but it would be unsafe to correct the carnotite analysis on that basis. Moreover, the analyses were not all made on the same plan; some are less complete than others; they can not in some respects be rigidly compared with one another.

As to the carrying out of the analysis, various procedures were tried and no one was found which gave altogether satisfactory results as to each constituent, though many could be determined with the usual degree of accuracy. The difficulty was due mainly to vanadium and the small amount of phosphoric acid usually present. These two constituents were likely to be found in different precipitates and could not be separated from them at one stroke. Their complete removal from other bodies was at times impossible, and the weight of the latter had then to be corrected for these residual amounts.

Two entirely different lines of attack were open. One, that of Friedel and Cumenge, described in their paper on carnotite, had already been used with apparent success. It depends on rendering the vanadium insoluble in water by evaporating the nitric acid solution to dryness. Water extracts the alkalies and uranium without 
dissolving the vanadium, iron, or aluminum. Repetition of this proc ess yielded Friedel and Cumenge satisfactory results. They recommended washing with water containing ammonium nitrate.

The other method involved the quantitative removal of vanadium by dry hydrochloric acid gas in the manner already described (pp. 18-19). Smith and Hibbs had shown that this method is perfect for alkaline pyrovanadates and it was hoped that it might succeed even with such complex mixtures as those under consideration. The distillations were made on the crude ore and also on the nitric acid solution after filtration from the insoluble matter and evaporation to thorough dryness. The action is immediate in the cold, copious red-brown vapors coming off and condensing in part as a dark red liquid in the tube. But repeated distillations and the application of heat were required to effect complete removal of the vanadium accompanied by the arsenic and molybdenum. After each distillation the contents of the boat had to be evaporated with nitric acid. The blue and green colorations apparent on adding this acid showed that the hydrochloric acid gas had reduced a good deal of the vanadium to a lower state of valence, and in this condition it was incapable of forming the volatile body.

A somewhat more satisfactory separation sometimes resulted when this distillation method was combined with that of Friedel and Cumenge by subjecting both the evaporated uranium nitrate solution and the residue insoluble in water to the action of hydrochloric acid gas.

The distillates obtained by either way were evaporated with sulphuric acid, the arsenic and molybdenum were separated by hydrogen sulphide, and the vanadium was then titrated by permanganate at a temperature near boiling and again after reduction by sulphur dioxide gas. In one or two cases when the temperature of distillation had been high and it was feared some iron had passed over, the distillates were evaporated in porcelain with nitric acid, transferred to a platinum crucible, evaporated therein with sulphuric acid, and fused with sodium carbonate. The aqueous extract was then treated as above for arsenic, molybdenum, and vanadium.

The mode of separation practiced by Friedel and Cumenge, while perhaps adequate for technical purposes in ores free from phosphorus, ${ }^{a}$ does not in my hands give perfect satisfaction even then. It is impossible to prevent a little of the vanadium, also of the iron and aluminum, from going with the uranium, and on the other hand a little uranium may stay with the vanadium. Again when the vanadic acid

\footnotetext{
$a$ With even only half a per cent of $\mathrm{P}_{2} \mathrm{O}_{5}$ many times that amount of $\mathrm{UO}_{3}$ is rendered insoluble in water after evaporation to dryness with nitric acid. The compound formed is of a lemon-yellow color, which is musked by the separated vanadic acid until this has been removed by ammonia. This insoluble body was treated as follows in order to arrive at the $\mathrm{P}_{2} \mathrm{O}_{5}$ and $\mathrm{UO}_{3}$ it contained. After solution in nitrite acid the phosphorus was precipitated by ammonium molybdate, and from the flltrate the uranium by three precipitations by ammonia.
} 
is extracted from the residue by ammonia, as prescribed by Friedel and Cumenge, a little of the other constituents of the residue accompany the vanadium into solution.

If the combination of the two methods is used, it is better, after the vanadium has been removed by distillation, to treat the two residues separately at first instead of to unite them at once. Full details of this treatment are unnecessary and would unduly extend this paper. Suffice it to say that from the uranium portion the little iron and aluminum present are separated by ammonium sulphide and carbonate, and after removal of the latter and acidification the uranium can be thrown down by ammonium sulphide, and then by at least two precipitations by ammonia, or far better, by precipitating the neutral hydrochloric solution by freshly precipitated and alkali-free mercuric oxide at boiling heat, as prescribed by Alibegoff. ${ }^{a}$ As pointed out by von Foullon and also by Alibegoff, contrary to certain still widely disseminated statements, ammonium sulphide does not afford a good separation of uranium from calcium. This is perhaps especially true if the solution contains any phosphorus. Again, contrary to another statement, it seems perfectly possible to separate uranium completely. from alkalies by a few ammonia precipitations.

The finally ignited and weighed $\mathrm{U}_{3} \mathrm{O}_{8}$ was redissolved in nitric acid, filtered; if necessary $\left(\mathrm{SiO}_{2}, \mathrm{Al}_{2} \mathrm{O}_{3}, \mathrm{Fe}_{2} \mathrm{O}_{3}\right)$, and divided into two parts, one of which was tested for the very little $\mathrm{P}_{2} \mathrm{O}_{5}$ usually present, and the other for vanadium by conversion into sulphate, reduction by sulphur dioxide gas, and titration by very dilute permanganate solution.

ANALYSES OF CARNOTITE ORES.

I. Copper Prince claim, Roc Creek, Montrose County, Colo.

According to the donor of the specimen, Mr. J. R. Duling, I- $a$ is from the same lot as that from which Mr. Poulot obtained the specimens afterwards analyzed by Friedel and Cumenge.

II. Yellow Boy claim, La Sal Creek, Montrose County, Colo.

III. Yellow Bird claim, La Sal Creek, Montrose County, Colo.

The last two claims belong to the same group and the ore is from the same "blanket" (Voillequé).

$I-b$ and II- $b$, the first analyses made, are not strictly comparable with the other analyses, since they represent the effect of warm dilute hydrochloric acid, whose greater action is shown by the nearly complete solution of the ferruginous admixture. Cold, dilute nitric acid was used for the other analyses.

a Ann. Chem. u. Phar., vol. 233, 1886, p. 133; Zeit für anal. Chemie, vol. 26, 1887, p. 632. 


\begin{tabular}{|c|c|c|c|c|c|c|}
\hline \multirow[t]{2}{*}{ • } & \multicolumn{3}{|c|}{ I. } & \multicolumn{2}{|c|}{ II. } & \multirow{2}{*}{ III. } \\
\hline & a. & $b$. & $c$. & $a$. & $b$. & \\
\hline Insoluble.. & a 7.10 & $b 8.34$ & c 19.00 & $d 10.33$ & $(e)$ & $(f)$ \\
\hline $\mathrm{UO}_{3} \ldots \ldots \ldots \ldots$ & 54.89 & 52.25 & 47.42 & 54.00 & 52.28 & 20.51 \\
\hline $\mathrm{V}_{2} \mathrm{O}_{5} \ldots \ldots \ldots \ldots$ & 1.8. 49 & 18.35 & 15. 76 & 18.05 & 17.50 & 7.20 \\
\hline $\mathrm{P}_{2} \mathrm{O}_{5} \ldots \ldots \ldots \ldots$ & .80 & .35 & .40 & .05 & trace & none \\
\hline $\mathrm{As}_{2} \mathrm{O}_{5} \ldots \ldots \ldots \ldots$ & trace & $\cdot .25$ & none & none & none & none \\
\hline $\mathrm{Al}_{2} \mathrm{O}_{3} \ldots \ldots \ldots \ldots$ & .09 & $(?)$ & .08 & .29 & $(?)$ & $.08 ?$ \\
\hline $\mathrm{Fe}_{2} \mathrm{O}_{3} \ldots \ldots \ldots$ & .21 & 1. 77 & .72 & .42 & 3.36 & .25 \\
\hline $\mathrm{CaO} \ldots$. & 3.34 & 2.85 & 2.57 & 1.86 & 1.85 & 1. 64 \\
\hline $\mathrm{SrO}$.. & .02 & $(?)$ & (?) & trace & trace & $(?)$ \\
\hline $\mathrm{BaO}$ & .90 & .72 & .65 & 2.83 & 3.21 & .29 \\
\hline $\mathrm{MgO}$ & .22 & .20 & .24 & .14 & .17 & .07 \\
\hline $\mathrm{K}_{2} \mathrm{O} \ldots \ldots \ldots$ & $6.52^{\circ}$ & 6.73 & 6.57 & 5.46 & 5.11 & 1.51 \\
\hline $\mathrm{Na}_{2} \mathrm{O} \ldots \ldots \ldots \ldots$ & .14 & .09 & .07 & .13 & $.02 ?$ & .01 \\
\hline $\mathrm{Li}_{2} \mathrm{O} \ldots \ldots \ldots$ & trace & $(?)$ & $(?)$ & trace & $(?)$ & $(?)$ \\
\hline $\mathrm{H}_{2} \mathrm{O}$ at $105^{\circ} \ldots$ & 2.43 & 2.59 & 1.85 & 3. 16 & 4.52 & 1.85 \\
\hline $\mathrm{H}_{2} \mathrm{O}$ at $350^{\circ} \ldots$ & 2. 11 & 3.06 & 2.79 & 2.21 & 3.49 & II. 64 \\
\hline $\mathrm{H}_{2} \mathrm{O}$ above $350^{\circ} \ldots$ & none & none & none & none & $\ldots \ldots \ldots$ & h. 19 \\
\hline $\mathrm{PbO} \ldots . . . . . . .$. & .13 & .25 & .18 & .07 & $\ldots \ldots \ldots$ & .09 \\
\hline $\mathrm{CuO} \ldots \ldots \ldots$ & .15 & .20 & .22 & trace & $\ldots \ldots \ldots$ & trace \\
\hline $\mathrm{SO}_{3} \ldots \ldots$ & none & .12 & .18 & none & $\ldots \ldots \ldots$ & none \\
\hline $\mathrm{MoO}_{3} \ldots \ldots \ldots \ldots$ & .18 & .23 & .18 & .05 & $\ldots \ldots \ldots$ & .04 \\
\hline $\mathrm{SiO}_{2} \ldots \ldots \ldots \ldots$ & .15 & .06 . & .13 & .20 & $\ldots \ldots$ & .07 \\
\hline $\mathrm{TiO}_{2} \ldots \ldots \ldots$ & .03 & .10 & $(?)$ & $(?)$ & . $\ldots \ldots \ldots$ & $\cdot 06 ?$ \\
\hline \multirow[t]{2}{*}{$\mathrm{CO}_{2} \ldots \ldots \ldots$} &. .56 & .33 & none & none & & \\
\hline & 98.46 & 98.84 & 99.01 & 99.25 & & \\
\hline
\end{tabular}

a Containing $0.54 \mathrm{H}_{2} \mathrm{O}, 0.09 \mathrm{~V}_{2} \mathrm{O}_{3}$.

$b$ The insoluble matter had the following composition: $\mathrm{SiO}_{2}, 5.18 ; \mathrm{V}_{2} \mathrm{O}_{3}, 0.21 ; \mathrm{P}_{2} \mathrm{O}_{5}, 0.09 ; \mathrm{K}_{2} \mathrm{O}, 0.26$; $\mathrm{Na}_{2} \mathrm{O}, 0.04 ; \mathrm{H}_{2} \mathrm{O}, 105^{\circ}, 0.56,350^{\circ}, 0.32,+350^{\circ}, 0.48 ; \mathrm{Al}_{2} \mathrm{O}_{3}, \mathrm{TiO}_{2}, \mathrm{Cr}_{2} \mathrm{O}_{3}$ etc., by diff., 1.20 . The $\mathrm{SO}_{3}$ of this ore is not combined with $\mathrm{BaO}$, for it is wholly extracted by dilute acids. Once in solution the acid used is sufficient to prevent its immediate precipitation as $\mathrm{BaSO}_{4}$ by union with some of the barium present. The same holds true for the $\mathrm{SO}_{3}$ of $\mathrm{I}-c$.

$c$ This material was obtained by floating off the finer matter, allowing it to settle, collecting on a Gooch filter, and drying it in a current of air drawn through the crucible. The insoluble matter held in addition to 16.41 quartz and silicates (including $0.39 \mathrm{~V}_{2} \mathrm{O}_{3}$ and a little $\mathrm{UO}_{3}$ ), $\mathrm{H}_{2} \mathrm{O}, 105^{\circ}, 0.83 ; 300^{\circ}$, $0.73 ;+300^{\circ}, 1.03$; total $\mathrm{H}_{2} \mathrm{O}, 2.59$.

$d$ Containing $0.16 \mathrm{~V}_{2} \mathrm{O}_{3}$ and $1.90 \mathrm{H}_{2} \mathrm{O}$.

$e$ The insoluble matter contained besides quartz and silicates: $0.25 \mathrm{~V}_{0} \mathrm{O}_{3}, 0.21 \mathrm{~K}_{2} \mathrm{O}, 0.05 \mathrm{Na} \mathrm{O}$.

$f$ This analysis was made purposely on a relatively poor ore, furnished by Messrs. Poulot and Voillequé, with the object of determining, if possible the composition of the vanadiferous silicate which it contained (see p. 30). The data for calculating the $\mathrm{H}_{2} \mathrm{O}$ values of both analyses are as follows:

\begin{tabular}{|c|c|c|c|}
\hline$\cdot$ & Ore. & $\begin{array}{l}\text { After extrac- } \\
\text { tion of carno- } \\
\text { tite by cold, } \\
\text { dilute nitric } \\
\text { acid. }\end{array}$ & $\begin{array}{l}\text { After extrac- } \\
\text { tion of resi- } \\
\text { due by hot } \\
\text { nitric acid, } \\
\text { sodium car- } \\
\text { bonate, etc. }\end{array}$ \\
\hline \multirow[t]{2}{*}{ 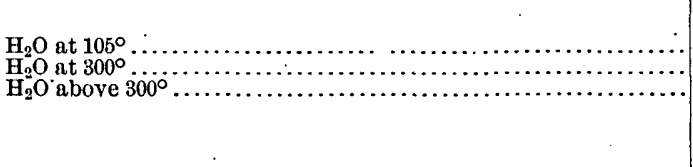 } & $\begin{array}{r}(a) \\
3.53 \\
2.11 \\
.83\end{array}$ & $\begin{array}{r}\text { (b) } \\
1.68 \\
.47 \\
.64\end{array}$ & $\begin{array}{r}\text { (c) } \\
0.02 \\
.03 \\
.02\end{array}$ \\
\hline & $-\quad 6.47$ & 2.79 & .07 \\
\hline
\end{tabular}

$a-b$ furnishes the values for the carnotite as shown in analysis III; $b-c$ gives those for the less soluble silicate (p. 30).

$g$ At $300^{\circ}$.

$h$ Above $300^{\circ}$ 
It will be noted that a somewhat marked deficiency appears in most of the analyses, the cause of which is quite unknown. Great care was exercised in most cases and especially in those which show the greatest loss. It seems hardly possible that any serious constant loss of a known constituent should have occurred, but the only alternative demands the presence of an element or elements unnoticed and which can not have been weighed with the known constituents. The researches of M. and Mme. Curie have shown that these ores contain traces of radio-active elements, precipitated the one by hydrogen sulphide; the other by sulphuric acid. Their presence, however, in quantity sufficient to account for the observed losses in the above analyses, especially when 10 grams of ore were operated on, could not possibly have escaped observation. To whatever cause it may be due, this loss alone suffices to render somewhat uncertain any calculations based on the analytical figures, though if the loss is to be ascribed to uranium or vanadium the ratios would not be sufficiently affected to obscure any simple relations that might exist. ${ }^{a}$

Another difficulty is the impossibility of knowing what constituents to exclude and what to include in deducing molecular ratios. It is certain that most if not all of the iron is foreign to the yellow body. It is probable that phosphorus is likewise so, since its extraction by dilute acids does not keep pace with that of the uranium and vanadium. It may possibly be in combination with the iron, in part at least. The alumina doubtless is derived from the vanadiferous silicate which seems to exist in all the ores and which is not quite insoluble in cold dilute acids. If so, a small portion of the vanadium, potassium, magnesium, and water are to be attributed to this mineral, but a general correction based on the analysis of this compound (see p. 30) would not be justifiable. Its application leads to nothing definite, even in the case of the particular ore No. III, from which the silicate analyzed was derived.

In the following tables are given first the recalculated analyses and then the molecular ratios. All those constituents have been excluded which pretty certainly do not belong to the carnotite, but small portions of some of those retained are unquestionably extraneous. In two cases (I- $a$ and $\mathrm{I}-b$ ) a certain proportion of lime has been arbitrarily excluded equivalent to the acid anhydrides $\mathrm{CO}_{2}, \mathrm{MoO}_{3}$, and $\mathrm{SO}_{3}$, less what is needed to offset $\mathrm{PbO}$ and $\mathrm{CuO}$.

a According to Dr. Harry C. Jones, of Johns Hopkins University, who very kindly undertook to examine a specimen of the Copper Prince ore for rare gaseous elements, helium is not present. Faint hydrogen lines were observed, the source of which was ascribed to water vapor. Other lines, due probably to hydrocarbons, were fairly strong, but the specimen had been long enough exposed in our laboratory and elsewhere to have accumulated enough dust to account for them. 
CARNOTITE ANALYSES RECALCULATED.

\begin{tabular}{|c|c|c|c|c|c|c|}
\hline & I- $a$. & $\mathrm{I}-b$ & I-c. & II- $a$. & II $-b$. & III. \\
\hline $\mathrm{V}_{2} \mathrm{O}_{5} \ldots \ldots$ & 20.72 & 21.09 & 20.12 & 20.54 & 19.85 & 20.62 \\
\hline $\mathrm{P}_{2} \mathrm{O}_{5} \ldots \ldots$ & .90 & .40 & .51 & .06 & 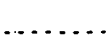 & $\ldots$ \\
\hline $\mathrm{As}_{2} \mathrm{O}_{5} \ldots \ldots$ & 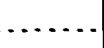 & .29 & & & & \\
\hline $\mathrm{UO}_{3} \ldots \ldots$ & 61.53 & 60.06 & 60.55 & 61.44 & 59.31 & 58.75 \\
\hline $\mathrm{CaO} \ldots \ldots$ & 3.03 & 2.77 & 3.28 & 2.11 & 2.10 & 4. 70 \\
\hline $\mathrm{BaO}(\mathrm{SrO}) \ldots$ & 1.03 & .83 & .83 & 3. 22 & 3.64 & .83 \\
\hline $\mathrm{MgO} \ldots . .$. & .25 & .23 & .31 & .16 & .19 & .20 \\
\hline $\mathrm{K}_{2} \mathrm{O} \ldots \ldots$ & 7.31 & 7.73 & $8 ., 39$ & 6.21 & 5.80 & 4.33 \\
\hline $\mathrm{Na}_{2} \mathrm{O} \quad \ldots .$. & .15 & .10 & .09 & .15 & .02 & .03 \\
\hline $\mathrm{H}_{2} \mathrm{O}-105^{\circ}$ & 2.72 & 2.98 & 2.36 & 3.59 & 5. 13 & 5.30 \\
\hline \multirow[t]{2}{*}{$\mathrm{H}_{2} \mathrm{O}+105^{\circ}$} & 2.36 & 3.52 & 3.56 . & 2.52 & 3.96 & 5. 24 \\
\hline & 100.00 & 100.00 & 100.00 & 100.00 & 100.00 & 100.00 \\
\hline
\end{tabular}

MOLECULAR RATIOS.

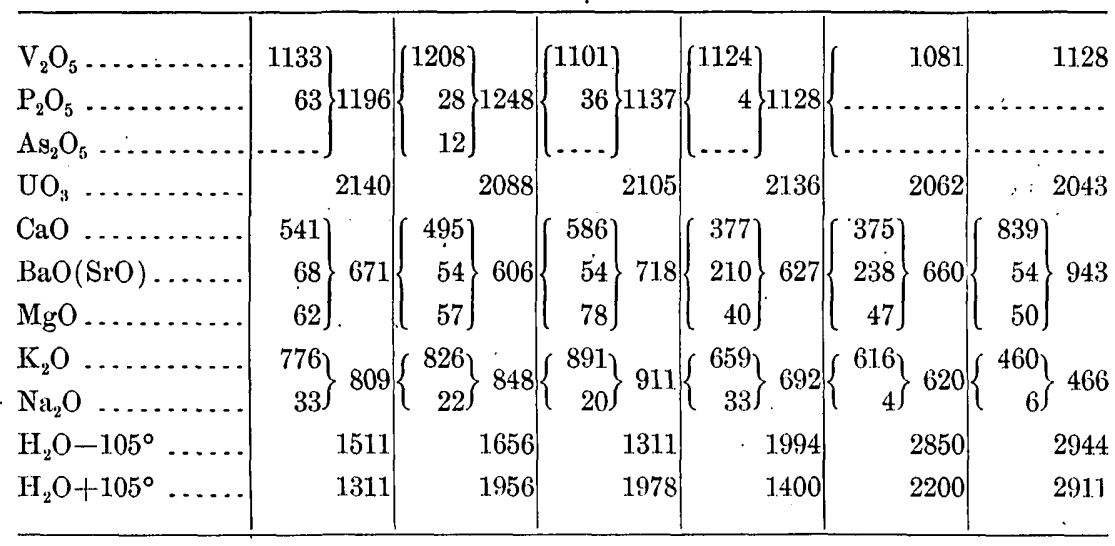

These ratios lead to the following empirical formulas, in which only the water given off above $105^{\circ}$ is considered. Since the water is wholly removable below $350^{\circ}$ it is regarded as water of crystallization and not of. constitution.

\begin{tabular}{|c|c|c|c|c|c|c|}
\hline & $\mathbf{R}^{\prime}$. & $\mathbf{R}^{\prime \prime}$. & $\mathrm{R}^{\mathrm{v}}$. & $\mathrm{U}$. & 0. & $\mathrm{H}_{2} \mathrm{O}$. \\
\hline $\mathrm{I}-a \ldots \ldots \ldots \ldots$ & 1618 & 671 & 2392 & 2140 & 13880 & 1311 \\
\hline $\mathrm{I}-b \ldots$ & 1696 & 606 & 2496 & 2088 & 13958 & 1956 \\
\hline $\mathrm{I}-c \ldots$ & 1822 & 718 & 2274 & 2105 & 13629 & 1978 \\
\hline II- $a \ldots$ & 1384 & 627 & 2256 & 2136 & 13367 & 1400 \\
\hline II $-b \ldots \ldots$. & 1240 & 660 & - 2162 & 2062 & 12871 & 2200 \\
\hline III $\ldots . . . .$. & 932 & 943 & 2256 & 2043 & 13178 & 2911 \\
\hline
\end{tabular}


If it be assumed that the bivalent elements offer the most accurate determinations, the above ratios may be reduced to the following simpler terms on that basis:

\begin{tabular}{|c|c|c|c|c|c|c|}
\hline & $\mathrm{R}^{\prime}$ & $\mathrm{R}^{\prime \prime}$ & $R^{v}$ & U. & 0. & $\mathrm{H}_{2} \mathrm{O}$ \\
\hline I- $a$. & 2.41 & 1 & 3. 56 & 3. 19 & 20.68 & 1.95 \\
\hline $\mathrm{I}-b$. & 2.80 & 1 & 4.12 & 3.45 & 23.03 . & 3.23 \\
\hline I-c : & 2.54 & 1. & 3.17 & 2.93 & 18.98 & 2.75 \\
\hline II $-a$ & 2.21 & 1. & 3.60 & 3.41 & 21.32 & 2. 23 \\
\hline $\mathrm{II}-b$ & 1.88 & 1 & 3.27 & 3.12 & 19.50 & 3.33 \\
\hline III . & .99 & 1. & 2.39 & 2.16 & 13.98 & 3. 09 \\
\hline
\end{tabular}

The results, however, show a great lack of agreement and wide variation. It is plain that no probable formula can be calculated for the yellow body. The variations are of such a nature as to indicate in the plainest manner that it is a mixture of several substances.

So detailed a discussion as the foregoing would hardly have been justified, in view of the negative conclusions arrived at, but for the fact that Messrs. Friedel and Cumenge in their paper announced a simple formula for the body examined by them and gave it the specific name carnotite. Their published analyses are as given below, from which they have excluded considerable sand and traces of barium, aluminum, lead, copper, and radio-active bodies as present in excessively small quantities. They make no mention of calcium and admit that their values for water are open to doubt. The formula deduced by them is $2 \mathrm{U}_{2} \mathrm{O}_{3},{ }^{a} \mathrm{~V}_{2} \mathrm{O}_{5}, \mathrm{~K}_{2} \mathrm{O}, 3 \mathrm{H}_{2} \mathrm{O}$.

\begin{tabular}{|c|c|c|c|c|c|}
\hline & \multicolumn{4}{|c|}{ Found. } & \multirow{2}{*}{ Calculated. } \\
\hline & 1. & 2. & 3. & 4. & \\
\hline $\mathrm{U}_{2} \mathrm{O}_{3} a \ldots \ldots \ldots \ldots \ldots \ldots$ & 64.70 & 62.46 & & & 63.54 \\
\hline $\mathrm{V}_{2} \mathrm{O}_{5} \ldots$ & 20.31 & 19.95 & & & 20.12 \\
\hline $\mathrm{K}_{2} \mathrm{O} \ldots \ldots \ldots \ldots \ldots$ & 10.97 & 11.09 & & $\therefore$ & 10. 37 \\
\hline $\mathrm{H}_{2} \mathrm{O} \ldots \ldots \ldots \ldots$ & & & 5.29 & 4.81 & 5.95 \\
\hline \multirow{2}{*}{$\mathrm{Fe}_{2} \mathrm{O}_{3} \ldots \ldots \ldots$} & .96 & .65 & & ....... & $\therefore \ldots$ \\
\hline & & & & & 99.98 \\
\hline
\end{tabular}

a old notation, equivalent to the-modern $\mathrm{UO}_{3}$.

It appears from these analyses that Messrs. Friedel and Cumenge by great good fortune obtained a variety of samples of the pure potassium compound, free from calcium and without appreciable admixture of 
barium. This is very remarkable in view of the fact that all the ores from different localities, examined by me show large admixture of calcium or barium salts or both, even that which is certified to have come from the same lot as that from which their material was taken. The French authors give a brief outline of their methods of analysis. That one which afforded them the best results would involve the weighing of any calcium present as sulphate along with the potassium, on the assumption that the presence of that element had been overlooked. It is much to be desired that a reanalysis of their material should be made, if there is any of it still available, in order to clear up the doubt connected with the first analysis.

In the light of the evidence herein set forth, the existence of a distinct mineral species having the composition claimed for carnotite can by no means be considéred as established.

\section{AVERAGE QUALITY OF MARKETED ORE.}

As these carnotite ore bodies are being exploited for the market, it is of some interest to know the average quality of each commercial lot. A carefully prepared sample representing several tons of ore was received from one of the commercial houses of Denver and was found to carry 11.49 per cent of uranium counted as $\mathrm{U}_{3} \mathrm{O}_{8}$, and 6.40 per cent of vanadium counted as $\mathrm{V}_{2} \mathrm{O}_{5}$. Over one-sixth of the vanadium existed, however, in the trivalent state, not as a constituent of the yellow body, but doubtless of a silicate like the one whose composition is given on page 30 .

COMMERCIAL ASSAY.

The commercial assay of these ores has presented difficulties to the technical chemist, the results being sometimes very discordant.

As to uranium, this is not surprising. The methods that have probably been commonly employed will give varying results, according to the contents of the ore in phosphorus and alkaline earths. Possibly the old Patera process, described in most text-books on analytical chemistry, might be made to serve, with modifications called for by the large amount of vanadium present.

The assay for vanadium presents little difficulty and does not require much time. The ore is fused with sodium carbonate, leached with water, and the fusion repeated on the residue. The combined filtrates are acidified by sulphuric acid, arsenic and molybdenum are precipitated in the hot solution by hydrogen sulphide, whereby the $\mathrm{V}_{2} \mathrm{O}_{5}$ is reduced to $\mathrm{V}_{2} \mathrm{O}_{4}$. After filtration and expulsion of hydrogen sulphide by boiling, the vanadium is titrated in hot solution by permanganate. It is then reduced by sulphur dioxide gas, and after boiling this out the titration is repeated. The results are exact, and they are not affected by the uranium that may be present. 


\section{COMPOSITION OF VANADIFEROUS SILICATE IN CARNOTITE ORE.}

As already mentioned, the ores contain a vanadiferous silicate free from uranium. To the end of ascertaining its composition, if possible, ore No. III (p. 25), from the Yellow Bird claim, low in carnotite, but relatively rich in vanadium, was treated as follows:

The carnotite from 10 grams was extracted by cold, dilute nitric acid, and the well-washed residue, consisting of coarse sand and an utterly amorphous mud, by 4 per cent sodium carbonate solution to get rid of the small amount of silica presumably. set free, but not dissolved by the acid. This amounted to 0.35 per cent in duplicate determinations, and together with 0.06 per cent in the acid solution, or 0.41 per cent in all, may serve as a maximum figure by which to gage the action of the cold acid on the silicate or silicates in the ore. The residue was then digested for several hours with warm nitric acid of about 1.2 specific gravity until, as shown by a companion test, its action had ceased. It was then filtered, washed, and digested with 5 per cent sodium carbonate solution to dissolve the copious deposit of silica. The final residue was collected in a Gooch crucible, washed with sodium carbonate, followed by dilute nitric acid to remove all alkali, then by alcohol to prevent turbidity in the filtrate, and dried by suction of the pump. In it the water was determined at different temperatures; also its general composition. ${ }^{a}$ From the sodium carbonate filtrate the silica was obtained by two evaporations and filtrations; also the trifling amount held by the acid solution. This latter was then fully analyzed and the complete results follow:

\begin{tabular}{|c|c|c|c|}
\hline & $\begin{array}{l}\text { Per cent in } \\
\text { ore. }\end{array}$ & $\begin{array}{c}\text { Per cent cal- } \\
\text { culated to } \\
100 .\end{array}$ & Ratios. \\
\hline $\mathrm{SiO}_{2} \ldots \ldots \ldots$ & 6.48 & 43.94 & 0.7275 \\
\hline $\mathrm{Al}_{2} \mathrm{O}_{3} \ldots \ldots \ldots \ldots$ & $b 2.445$ & 16.58 & $0.1622)$ \\
\hline $\mathrm{V}_{2} \mathrm{O}_{3} \ldots \ldots \ldots \ldots \ldots \ldots \ldots \ldots$ & $c .965$ & 6.54 & $.0434\} .2426$ \\
\hline 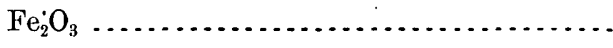 & $d .875$ & 5.93 & $.0370)$ \\
\hline $\mathrm{CaO} \ldots \ldots \ldots$ & .035 & .24 & $.0043\}$ \\
\hline $\mathrm{MgO} \ldots \ldots \ldots \ldots \ldots \ldots \ldots \ldots$ & $e .654$ & 4.43 & $.1099\} \cdot 1142$ \\
\hline $\mathrm{K}_{2} \mathrm{O} \ldots \ldots \ldots \ldots \ldots \ldots \ldots \ldots \ldots \ldots \ldots \ldots \ldots \ldots \ldots \ldots \ldots$ & .546 & 3.70 & $.0393\} \quad 0430$ \\
\hline 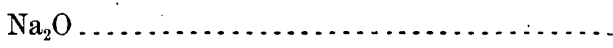 & .03 & .20 & $.0037\}^{.0430}$ \\
\hline $\mathrm{H}_{2} \mathrm{O}$ at $105^{\circ} \mathrm{C} \ldots \ldots \ldots \ldots \ldots \ldots \ldots \ldots \ldots$ & $f 1.66$ & 11. 26 & .9222 \\
\hline 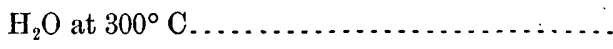 & $f .44$ & 2.98 & .1655 \\
\hline \multirow[t]{2}{*}{ 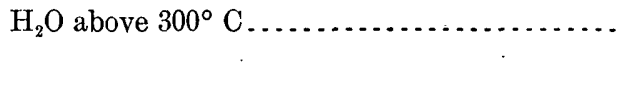 } & $f .62$ & 4.20 & .2333 \\
\hline & 14. 75 & 100.00 & \\
\hline
\end{tabular}

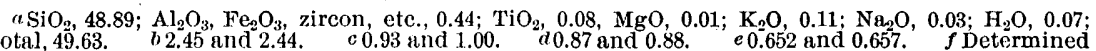
total, 49.63 . $b 2.45$ and 2.44 . $\quad c 0.93$ and 1.00 . d $\quad 0.87$ and 0.88 . $e 0.652$ and 0.657.
on a separate portion of the same powdered sample. See p. 25 , footnote, for data.

Also traces of titanium, manganese, and lithium. 
On the improbable assumption that the iron is to be wholly included, and regarding only the water given off above $300^{\circ}$, the following ratios result:

$$
\mathrm{H}_{467} \mathrm{R}_{86}^{\prime} \mathrm{R}_{114}^{\prime \prime} \mathrm{R}^{\prime \prime \prime}{ }_{485} \mathrm{Si}_{727} \mathrm{O}_{2573}
$$

which become, if the iron is excluded,

$$
\mathrm{H}_{467} \mathrm{R}_{86}^{\prime} \mathrm{R}^{\prime \prime}{ }_{114} \mathrm{R}^{\prime \prime \prime}{ }_{411} \mathrm{Si}_{727} \cdot \mathrm{O}_{2462} \text {. }
$$

These figures, while strongly suggesting definite ratios between certain of the constituents, do not under the circumstances warrant the deduction of a formula, nor do they lead to the same conclusion as in the case of the green cementing material of the sandstone at Placerville. The phengite-muscovite ratio of that is not apparent here; yet it is not at all unlikely that a mineral like the one from Placerville is present, but contaminated with some other. In fact it would be surprising to find anything but a mixture in sandstones so thoroughly altered. The very existence of such vanadiferous transition products is itself highly interesting, and these tedious analyses were not therefore made in vain. The mud-like amorphous character of this material precludes any hope of aid from the microscope in solving the question of its homogeneity.

\section{SUMMARY.}

The body called carnotite is probably a mixture of minerals, the exact nature of which analysis fails to reveal. Instead of being the pure uranyl-potassium vanadate, it is to a large extent made up of calcium and barium compounds. Intimately mixed with and entirely obscured by it is an amorphous substance-a silicate or mixture of silicates-containing vanadium.in the trivalent state probably replacing aluminum.

The deposits of carnotite, though distributed over a wide area of country, are for the most part, if not altogether, very superficial in character and of recent origin.

The green coloring and cementing material of certain sandstones near Placerville, Colo., is a cryptocrystalline alumino-vanadio-potassium silicate resembling roscoelite, but with the percentage proportions of $\mathrm{Al}_{2} \mathrm{O}_{3}$ and $\mathrm{V}_{2} \mathrm{O}_{3}$ reversed. It constitutes over 25 per cent of portions of the sandstone, and contains nearly 13 per cent of $\mathrm{V}_{2} \mathrm{O}_{3}$, the latter amounting in the maximum case observed to 3.5 per cent of the sandstone..

As yet (1900) these highly vanadiferous sandstones have been found only at Placerville, where it is intended to work them for vanadium. Carnotite is associated with them in only trifling amount.

Other sandstones noticed owe their bright green color to chromium.

In yet another case where the color was dull green this was not due to either chromium or vanadium. 


\section{SOME ADDITIONS TO THE ALUNITE-JAROSITE GROUP OF MINERALS.}

By W. F. Hillebrand and S. L. Penfieid.

Two new varieties of jarosite will be described in the present paper. One is from Nevada, and was collected by Mr. H. W. Turner, of the. United States Geological Survey, and sent to the Survey laboratory at Washington for identification; the other is from New Mexico, and was sent by Mr. J. H. Porter, of Denver, Colo., to the mineralogical laboratory of the Sheffield Scientific School. Except for slight differences in color the two minerals look exactly alike, each

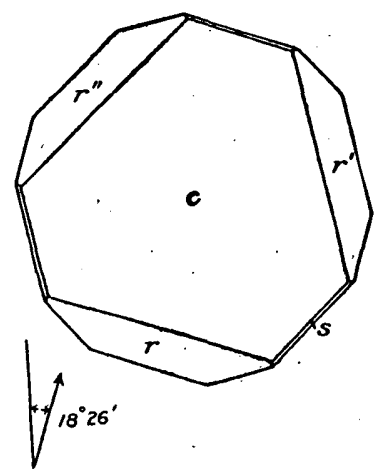
consisting of minute, isolated, tabular crystals, which, as may be seen with the microscope, are composed of combinations of a rhombohedron with largely developed basal planes. By chance it happened that the present writers discovered that they were both engaged in the investigation of compounds belonging eridently to the same group, and it was decided to bring the results together into one paper.

\section{NATROJAROSITE.}

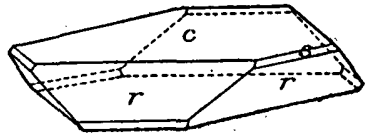

Fig. 1.-Natrojarosite.

The material collected by Mr. Turner was obtained on the east side of Soda Springs Valley, Nevada, on the road from Sodaville to the Vulcan copper mine. It consists of a glistening powder, made up of perfect crystals having the habit shown in fig. 1, although generally only one rhombohedron, $r$, is present instead of two, as shown in the figure. The largest crystals observed were $0.15 \mathrm{~mm}$. wide and $0.025 \mathrm{~mm}$. thick, and the general average would not be over half that size. In spite of their minuteness, however, it was possible to measure the angles of the crystals with the reflection goniometer, the chief difficulty arising not so much from their small size as from the vicinal character of the basal planes. After repeated trials a crystal was 
found having a fairly good basal plane, and from this crystal the following angles were obtained:

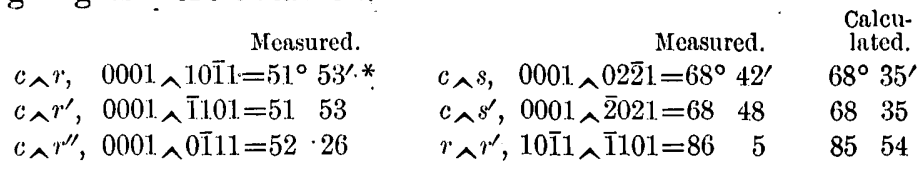

The crystals belonged to the rhombohedral division of the hexagonal system, and the angle $c \wedge r, 51^{\circ} 53^{\prime}$, which is probably very nearly correct, has been assumed as fundamental, and from it the following axial ratio has been calculated:

$$
c=1.104 \text {. }
$$

That the axial ratio as given is very near the truth is shown by the fact that the measurements of $c \wedge s$ and $r \wedge r$ do not vary many minutes from the calculated values; while on a number. of other crystals, measurement of the angle $c \wedge r$, though varying considerably, was found to be not far from $52^{\circ}$. The angles of $c \wedge r$ and $r \wedge r^{\prime}$ of the ordinary potassium jarosite are $55^{\circ} 16^{\prime}$ and $90^{\circ} 45^{\prime}$, respectively.

Under the microscope the crystals exhibit normal optical properties. With a high-power lens and convergent light the thicker crystals show the dark crioss and the beginnings of the first ring of the interference figure. The birefringence is negative. The color of single crystals, when seen under the microscope in transmitted light, is golden yellow. Many of the crystals show numerous brown inclusions. The color shown by a mass of the crystals is yellowish brown, and the material glistens, owing to reflections from the basal planes of the minute crystals.

The material used for the chemical analysis was the purest that could be obtained, although crystals containing the brownish inclusions just mentioned could not be avoided, and there were occasional brown ferruginous particles mixed with the crystals. The specific gravity of the material was found to be 3.18 at $30.5^{\circ} \mathrm{C}$. The results of the analysis by Hillebrand are as follows:

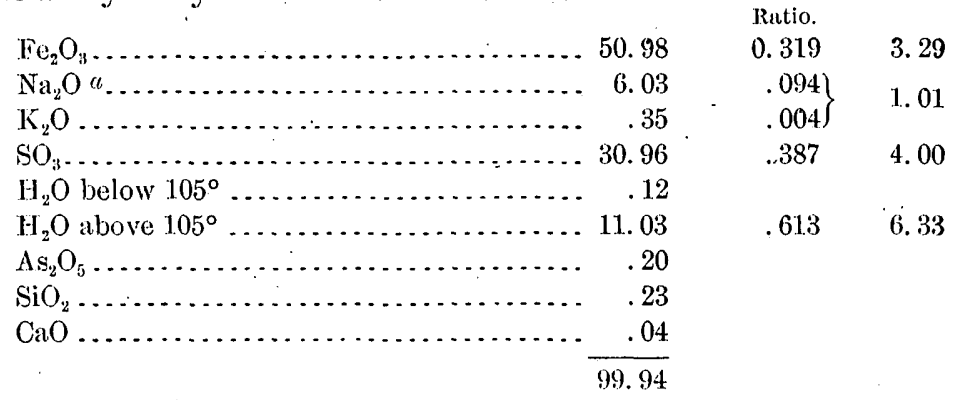

a Of the soda 0.22 per cent is not extracted by hot water after full ignition of the mineral, and hence muy belong to a feldspar or some other foreign mineral. Only 5.81 per cent is assumed to belong to the jacosite and used in deriving the molecular valuę:

Bull. 262-05-3 
The ratio of $\mathrm{Fe}_{2} \mathrm{O}_{3}: \mathrm{Na}_{2} \mathrm{O}: \mathrm{SO}_{3}: \mathrm{H}_{2} \mathrm{O}$ is evidently $3: 1: 4: 6$ as in ordinary jarosite, where the alkali is potash instead of soda. The slight excess of $\mathrm{Fe}_{2} \mathrm{O}_{3}$ and $\mathrm{H}_{2} \mathrm{O}$, as indicated by the ratio, is evidently due to some ferric hydroxide; probably the dark ferruginous impurities seen under the microscope are in part responsible for this, and there are also traces of some arsenate and silicate present. By attributing the excess of $\mathrm{Fe}_{2} \mathrm{O}_{3}$ and $\mathrm{H}_{2} \mathrm{O}$ to impurities, it is found that 94 per cent of the material analyzed may be regarded as pure natrojarosite, as indicated below:

\begin{tabular}{|c|c|c|}
\hline . & $\begin{array}{l}\text { After deducting impuri- } \\
\text { ties. }\end{array}$ & $\begin{array}{c}\text { Theory for } \\
\mathrm{Na}_{2} \mathrm{Fe}_{h}[\mathrm{OH}]_{12} \\
{\left[\mathrm{SO}_{4}\right]_{4} .}\end{array}$ \\
\hline $\mathrm{Fe}_{2} \mathrm{O}_{3} \ldots \ldots$. & 46.43 or 49.39 & 49.49 \\
\hline 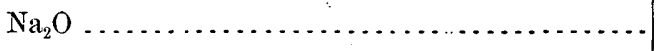 & 5.81 or 6.18 & 6.39 \\
\hline $\mathrm{K}_{2} \mathrm{O} \ldots \ldots \ldots \ldots$ & .35 or $\quad .37$ & \\
\hline 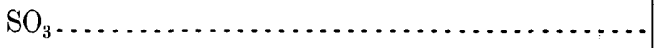 & 30.96 or 32.94 & 32.99 \\
\hline \multirow[t]{2}{*}{$\mathrm{H}_{2} \mathrm{O} \ldots \ldots \ldots \ldots \ldots$} & 10. 45 or 11.12 & 11. 13 \\
\hline & 94.00 or 100.00 & 100. 00 \\
\hline
\end{tabular}

That 6 per cent of impurities should be present in a crystalline powder such as was analyzed is not surprising when it is taken into consideration that it would require something like 2,500,000 crystals to make one gram of material, the estimation being based on the assumption that the crystals are $0.10 \mathrm{~mm}$. in axial diameter and 0.02 mm. thick, which is certainly above their average size.

Among the specimens from Cooks Peak, New Mexico, sent to the Sheffield laboratory by Mr. Porter, were some masses of a rather firmly cemented aggregate of minute crystals of a mineral of the jarosite group. The specimens are of a brownish-yellow color, and have in places the glistening appearance of a mica-schist. They also look as though they had been subjected to pressúre and had been somewhat sheared. The material is rather easily crushed, and the powder, when examined with the microscope, exhibits the proprieties of the natrojarosite just described. The crystals are associated with a little limonite and quartz, and pure material for analysis could not be obtained. Only a partial analysis, therefore, was undertaken with the following results:

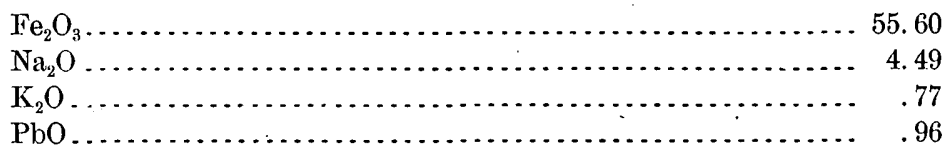

$\mathrm{SO}_{3}$ and $\mathrm{H}_{2} \mathrm{O}$ were present but not determined. The results are sufficient to indicate that the material is essentially natrojarosite. 


\section{PLUMBOJAROSITE.}

This material is from Cooks Peak, New Mexico. It occurs as a glistening, crystalline powder and as loosely cohering masses which may easily be crushed by pressure between the fingers. The crystals are very symmetrical, and are exactly like those of natrojarosite (fig. 1 ), although generally only one rhombohedron, $r$, is present. On the average the crystals are a trifle smaller and noticeably thinner than those of natrojarosite. A number of crystals were measured on the reflecting goniometer, the chief difficulty arising rather from the vicinal character' of the faces than from their small size. One unusually large crystal, $0.28 \mathrm{~mm}$. broad and $0.015 \mathrm{~mm}$. thick, was finally found, having the development shown in fig. 2, which is unusual, for generally $r(10 \overline{1} 1)$ and not $s(02 \overline{2} 1)$ is the prevailing rhombohedron. Fortunately the crystal was so taken up on a minute point of wax that the measurement of $s \wedge s$ in three rhombohedral zones was possible. The results of five measturements of $s$ sover the upper and lower pole edges varied between $109^{\circ} 5^{\prime}$ and $109^{\circ} 30^{\prime}$, the average being $109^{\circ} 16^{\prime}$; while

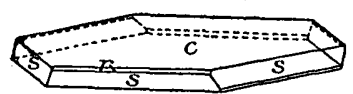

FIG. 2,-Plumbojarosite. six measurements over the middle edges varied between $70^{\circ} 10^{\prime}$ and $71^{\circ} 00^{\prime}$, the average being $70^{\circ} 36^{\prime}$. The average of the two supplementary values gives $s \wedge s, 2 \overline{2} 01 \wedge 02 \overline{2} 1=109^{\circ} 20^{\prime}$, which has been assumed as fundamental, and from it the following axial ratio has been calculated:

$$
c=1.216 \text {. }
$$

On the crystal from which the foregoing measurements were obtained the basal plane was vicinal and hence no reliable measurements of $c_{\wedge} s$ could bë had from it. On a number of other crystals, however, the angle of $c_{\wedge} r$ was measured with varying. results, the variation resulting from the uncertainty of the reflections from the basal planes. Four measurements of $c \wedge r$, which were recorded in the notebook as derived from the best reflections, varied between $54^{\circ} 15^{\prime}$ and $54^{\circ} 44^{\prime}$, the average being. $54^{\circ} 30^{\prime}$, while $c_{\wedge} r, 0001 \wedge 10 \overline{1} 1$, by calculation from the fundamiental measurement, is $54^{\circ} 32^{\prime}$. Hence it may be assumed that the axial ratio as established is reasonably exact. The calculated. value of $r \wedge r, 10 \overline{1} 1 \wedge \overline{1} 101$, is $89^{\circ} 42^{\prime}$.

In polarized light the crystals exhibit normal optical properties and negative birefringence. Being on the average thinner than crystals of natrojarosite, it is seldom that, with the highest powers and convergent light, even the beginning of the first ring of the uniaxial interference figure is visible. Individual crystals show under the microscope in transmitted light a golden-yellow color. A mass of crystals has the appearance of a glistening dark-brown powder, the color being decidedly darker than that of natrojarosite. 
The analysis of the mineral was made on the very best material, having a specific gravity of 3.665 at $30^{\circ} \mathrm{C}$. The results are surprising, and were wholly unlooked for, since it is found that this jarosite contains lead in the place of alkalies. The results by Hillebrand are as follows:

\begin{tabular}{|c|c|c|c|c|c|c|}
\hline & I. & II. & III. & IV. & Mean. & Ratio. \\
\hline $\mathrm{Fe}_{2} \mathrm{O}_{3} \ldots \ldots$ & 42.36 & 42.38 & 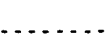 & & 42.37 & $0.265\}_{3}$ \\
\hline $\mathrm{Al}_{2} \mathrm{O}_{3} ? \leftrightarrow \ldots \ldots \ldots$ & .12 & .08 & 0.11 & $\ldots \ldots$ & . .10 & $.001\}^{3}$ \\
\hline $\mathrm{PbO} \ldots \ldots \ldots$ & 19.69 & 19.99 & 19.89 & 19.79 & 19.84 & $.089 \quad 1.05$ \\
\hline $\mathrm{K}_{2} \mathrm{O} \ldots \ldots \ldots$ & .17 & $\ldots \ldots$. & & & .17 & \\
\hline $\mathrm{Na}_{2} \mathrm{O} \ldots \ldots \ldots \ldots \ldots$ & b. 21 & & & & b. 21 . & ... \\
\hline $\mathrm{SO}_{3} \ldots \ldots \ldots \ldots$ & 27.05 & 27.07 & & & 27.06 & $.338 \quad 4.00$ \\
\hline $\mathrm{H}_{2} \mathrm{O}$ below $105^{\circ} \ldots$ & .02 & $\ldots \ldots$ & & & .02 & $\ldots$ \\
\hline $\mathrm{H}_{2} \mathrm{O}$ above $105^{\circ} \ldots \ldots$ & 9.59 & 9.49 & & & 9.54 & $.530 \quad 6.27$ \\
\hline $\mathrm{SiO}_{2} \ldots \ldots \ldots \ldots$ & .56 & .51 & .47 & & .51 & \\
\hline $\mathrm{CuO}$ & .27 & .27 & 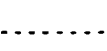 & & .27 & \\
\hline $\mathrm{CaO} \ldots \ldots, \ldots$ & .05 & 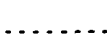 & & & .05 & \\
\hline \multirow[t]{2}{*}{$\mathrm{MgO} \ldots \ldots \ldots \ldots \ldots$} & .01 & ......... & & & .01 & \\
\hline & & & & & 100.15 & \\
\hline
\end{tabular}

a The presence of alumina was not definitely proved. The figures here given are the differences between. the several weights of the ammonia precipitates and those of the ferric iron in them, as determined by permanganate after reduction by hydrogen sulphide.

$b$ Probably somewhat high.

The ratio of $\mathrm{Fe}_{2} \mathrm{O}_{3}: \mathrm{PbO}: \mathrm{SO}_{3}: \mathrm{H}_{2} \mathrm{O}$ is very close to $3: 1: 4: 6$, indicating that the mineral is a variety of jarosite, and the slight excess of $\mathrm{Fe}_{2} \mathrm{O}_{3}, \mathrm{H}_{2} \mathrm{O}$, and $\mathrm{PbO}+$ alkalies may be accounted for by assuming that slight impurities are present, partly ferric hydroxide, in part some lead salt, and perhaps a soluble silicate, as shown by the complete solubility of the silica in acids. Assuming that the ratio is exactly $3: 1: 4: 6$, it is found that 4.36 per cent of impurities are present, and the remaining 95.64 per cent may then be regarded as plumbojarosite, as follows:

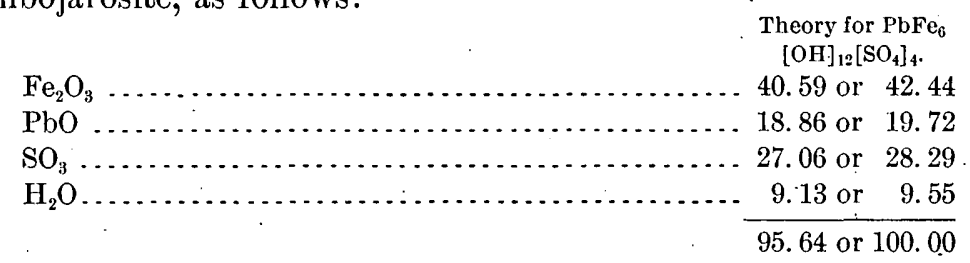

Since it took probably $2,500,000$ crystals of natrojarosite to make 1 gram of material, it certainly must have taken fully $4,000,000$ to make a gram of plumbojarosite, for the crystals of the latter mineral, though somewhat heavier, are decidedly thinner than those of the former; hence the presence of 4.5 per cent of impurities in such a crystalline product is not to be wondered at. 


\section{JAROSITE AND ALUNITE.}

As may be seen from the published analyses of these minerals, the alkali metal they contain is almost always potassium, though sodium is at times present. The formulas assigned to the two minerals are therefore $\mathrm{K}_{2} \mathrm{O}+3 \mathrm{Fe}_{2} \mathrm{O}_{3}+4 \mathrm{SO}_{3}+6 \mathrm{H}_{2} \mathrm{O}$ and $\mathrm{K}_{2} \mathrm{O}+3 \mathrm{Al}_{2} \mathrm{O}_{3}+4 \mathrm{SO}_{3}+6 \mathrm{H}_{2} \mathrm{O}$, which may be variously expressed, as will be indicated later.

A mineral corresponding to natrojarosite of this article, though containing a little potash, has been described by W. P. Headden ${ }^{a}$ from the Buxton mine, Lawrence County, S. Dak. The crystals are described as scales, consisting of a combination of base and rhombohedron. The material analyzed was evidently somewhat impure, as quartz and some $\mathrm{As}_{2} \mathrm{O}_{5}$ are reported. $\mathrm{As}$ the $\mathrm{As}_{2} \mathrm{O}_{5}$ evidently does not belong to jarosite, the assumption may be made that some scorodite, $\mathrm{FeAsO} \mathrm{O}_{4} \cdot 2 \mathrm{H}_{2} \mathrm{O}$, is present, and the results of Headden's analysis may then be interpreted as follows:

\begin{tabular}{|c|c|c|c|c|}
\hline- & $\begin{array}{l}\text { Original } \\
\text { analysis. }\end{array}$ & $\begin{array}{l}\text { Scorodite } \\
\text { and quartz. }\end{array}$ & Natrojarosite. & Ratio. \\
\hline $\mathrm{Fe}_{2} \mathrm{O}_{3} \ldots \ldots$ & 46.27 & 1.60 & 44.67 or 50.10 & 3.13 \\
\hline $\mathrm{Na}_{2} \mathrm{O} \ldots \ldots ; \ldots \ldots$ & 4.35 & $\cdots \cdots$ & 4.35 or 4.86 & \\
\hline $\mathrm{K}_{2} \mathrm{O} \ldots \ldots$ & 1.47 & $\ldots .$. & 1.47 or 1.65 & 1.04 \\
\hline $\mathrm{CaO} \ldots$ & $.39 \cdot$ & ..... & .39 or .44 & \\
\hline $\mathrm{SO}_{3} \ldots \ldots \ldots \ldots \ldots \ldots \ldots$ & 28.46 & ...... & 28.46 or 31.93 & 4.00 \\
\hline $\mathrm{H}_{2} \mathrm{O} \ldots \ldots \ldots \ldots$ & 10.55 & .72 & 9.83 or 11.02 & 6. 13 \\
\hline $\mathrm{As}_{2} \mathrm{O}_{5} \ldots, \ldots \ldots \ldots \ldots \ldots \ldots$ & 2.36 & 2.36 & & \\
\hline \multirow[t]{2}{*}{ Quartz...$\ldots \ldots \ldots \ldots \ldots \ldots \ldots$} & 6.10 & 6. 10 & $\cdot$ & $\ldots \ldots$ \\
\hline & 99.95 & 10.78 & 89.17 or 100.00 & \\
\hline
\end{tabular}

Thus, assuming the presence of 4.68 per cent of scorodite and 6.10 of quartz, and deducting them, the remainder agrees very closely with natrojarosite, giving a good ratio, very near $3: 1: 4: 6$.

Alunite containing considerable soda has been described by Whitman Cross ${ }^{b}$ from Rosita Hills, Colorado, and by E. B. Hurlburt ${ }^{c}$ from Red Mountain, Colorado, and analyses of both minerals show about. equal percentages of $\mathrm{K}_{2} \mathrm{O}$ and $\mathrm{Na}_{2} \mathrm{O}$, or a molecular ratio of $\mathrm{K}_{2} \mathrm{O}: \mathrm{Na}_{2} \mathrm{O}=4: 7$. The occurrence, therefore, of sodium in the jarositealunite group is in accordance with previous observations, but the case is quite different with lead. As far as the present writers are aware, this is the first instance on record where lead has been observed isomorphous with the alkali metals. It is interesting to note that the alunite from Red Mountain, Colorado, occurs as a crystalline powder, the crystals being exactly like those of natrojarosite and plumbojaro- 
site, except that they are a trifle smaller and white, or colorless, when . seen under the microscope.

From a chemical standpoint the most interesting feature of the new minerals is the light they throw upon the isomorphism of potassium, sodium, and lead. Ordinarily, even potassium and sodium are not isomorphous, as shown by the fact that their simple salts seldom crystallize in the same form. Although $\mathrm{KCl}$ and $\mathrm{NaCl}$ both crystallize in cubes, it is not certain that both salts belong to the same group of the isometric system. It has been shown, for example, by etching; that $\mathrm{KCl}$ crystallizes like $\mathrm{NH}_{4} \mathrm{Cl}$ in the plagihedral group of the isometric system, while the etchings produced on halite seem to indicate that it crystallizes in the normal group. Again, at Stassfurt, Germany, sylvite and halite both occur crystallized side by side upon the same hand specimen, instead of mixing as isomorphous molecules. Even in such complex molecular compounds as the feldspars, the potassium and sodium salts crystallize as orthoclase and albite, rather than as isomorphous mixtures. Lastly, potassium has a strong tendency to form alums, which is not shared by sodium. In contrast to these differences in chemical nature, we have in the jayosite-alunite group of minerals not only the alkali-metals, potassium and sodium, but, what seems still more remarkable, lead, playing the same rôle in the compounds, and yielding crystals which are. surprisingly alike in all their physical properties. The writers can at present offer no other reason for the isomorphism in the group of minerals under consideration than that the alkalies and lead play so small a rôle, and the remaining constituents so prominent a part in the complex chemical molecules, that the latter control or dominate the crystallization by virtue of what may be called their mass effect.

The alunite from Red Mountain, described by Hurlburt, was analyzed in the Sheffield mineralogical laboratory under the direction of one of the present writers, and it was found that water was first expelled from the compound at a rather high temperature, thus indicating that the mineral contains hydroxyl and no water of crystallization; accordingly it was shown that the seemingly complex formula of the mineral, expressed by the ration $\mathrm{Al}_{2} \mathrm{O}_{3}: \mathrm{K}_{2} \mathrm{O}: \mathrm{SO}_{3}: \mathrm{H}_{2} \mathrm{O}=3: 1$ : $4: 6$, may be much simplified to $\mathrm{K}\left[\mathrm{Al}(\mathrm{OH})_{2}\right]_{3}\left[\mathrm{SO}_{4}\right]_{2}$. In the light of the present investigation it now seems best to abandon the above simple formula and adopt one containing double the number of atoms, in order to make clear the isomorphism between $\mathrm{K}_{2}, \mathrm{Na}_{2}$, and $\mathrm{Pb}$. The formulas of the minerals of the group would then be expressed as follows:

Alunite ............................... Natroalunite.................. Na $2\left[\mathrm{Al}(\mathrm{OH})_{2}\right]_{6}\left[\mathrm{SO}_{4}\right]_{4}$ or $\mathrm{Na}_{2} \mathrm{Al}_{6}[\mathrm{OH}]_{12}\left[\mathrm{SO}_{4}\right]_{4}$

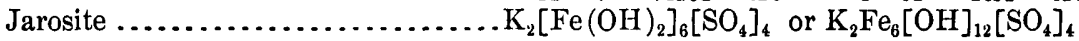
Natrojarosite ..................... $\mathrm{Na}_{2}\left[\mathrm{Fe}(\mathrm{OH})_{2}\right]_{6}\left[\mathrm{SO}_{4}\right]_{4}$ or $\mathrm{Na}_{2} \mathrm{Fe}_{6}[\mathrm{OH}]_{12}\left[\mathrm{SO}_{4}\right]_{4}$ Plumbojarosite ................... 
In the case of the lead compound one atom of lead, and in the other's two atoms of either potassium or sodium, are combined in complex molecules containing fifty other atoms; hence that the complex of fifty atoms, to the right of the $\mathrm{K}_{2}, \mathrm{Na}_{2}$ and $\mathrm{Pb}$ in the foregoing formulas, should control or dominate crystallization by virtue of mass effect, and condition an isomorphism between such unlike elements as sodium, potassium, and lead is not so surprising as would at first appear.

Having adopted the double formulas, as given above, there are numerous ways of writing developed formulas, of which the following are perhaps the simplest and most satisfactory:

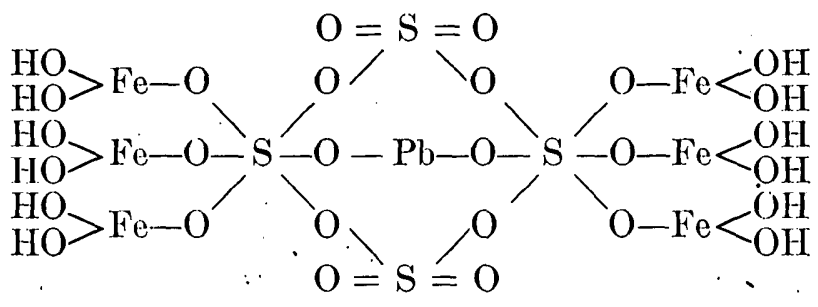

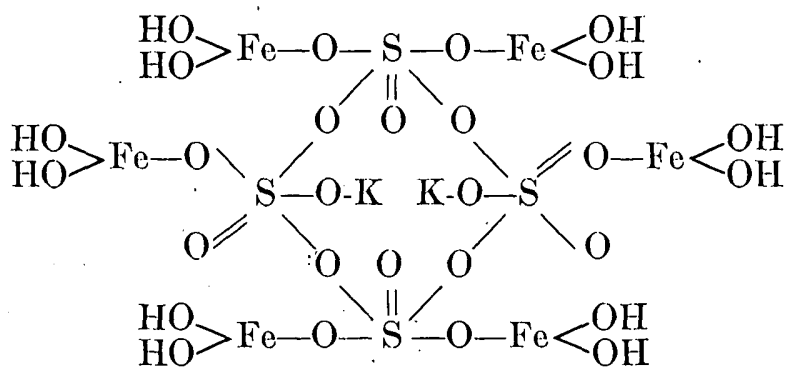

It is interesting to note that although $\mathrm{K}_{2}, \mathrm{Na}_{2}$ and $\mathrm{Pb}$ play so small a rôle in the alunite-jarosite molecules, the substitution of $\mathrm{Na}_{2}$ for $\mathrm{K}_{2}$ is attended by a marked variation in the angles of the crystals, greater, in fact, than is generally observed in isomorphous replacements. That alunite and jarosite containing potash would be nearly alike in their angles is expected, since crystals of corundum and hematite are surprisingly alike, as shown by the following comparison:

\begin{tabular}{|c|c|c|c|}
\hline & $\begin{array}{l}\text { Axinl } \\
\text { length. }\end{array}$ & $r \wedge r^{\prime}$ & $c \wedge r$ \\
\hline & & & \\
\hline Corundum, $\mathrm{Al}_{2} \mathrm{O}_{3} \ldots \ldots \ldots \ldots \ldots \ldots \ldots . . . .$. & 1.3630 & 9356 & $57 \quad 34$ \\
\hline Hematite, $\mathrm{Fe}_{2} \mathrm{O}_{3} \ldots \ldots \ldots \ldots \ldots \ldots \ldots \ldots \ldots \ldots \ldots \ldots \ldots \ldots \ldots \ldots$ & .1 .3656 & $94 \quad 00$ & $57 \quad 37$ \\
\hline
\end{tabular}


The relations of the minerals of the alunite-jarosite group are as follows:

\begin{tabular}{|c|c|c|c|c|}
\hline & $\begin{array}{l}\text { Axinl } \\
\text { length. }\end{array}$ & $r_{\wedge} r^{\prime}$ & $c_{\wedge} r$ & Birefringence. \\
\hline Alunite ..... & 1.. 252 & $\begin{array}{cc}\circ & \prime \\
90 & 50\end{array}$ & $\begin{array}{cc}0 & 1 \\
55 & 19_{3}^{2}\end{array}$ & Positive. \\
\hline Jarosite.......... & 1. 245 & $90 \quad 45$ & $55 \quad 16$ & Negative. \\
\hline Natrojarosite . . . . . . . & 1. 104 & $85 \quad 54$ & 51.53 & Do. \\
\hline Plumbojarosite ............ & 1.216 & $89 \quad 42$ & $54 \quad 32$ & Do. \\
\hline
\end{tabular}

From the foregoing table it is seen that the substitution of sodium for potassium in jarosite has brought about greater variation in the angles of the crystals than the substitution of the bivalent metal lead for potassium.

The three minerals, natrojarosite, plumbojarosite, and the Na-Kalunite from Red Mountain, are very interesting when studied together as microscopic mounts, the crystals being practically alike in size and development, and illustrating very beautifully on the one hand the isomorphism of aluminum and iron, on the other the isomorphism of potassium, sodium, and lead. The three substances must have formed under like conditions, and it is believed that they are solfataric products, formed under the combined action of heat and pressure. Being difficultly soluble, they have formed, like many precipitates, as fine crystalline powders.

The three products just mentioned, when heated in closed tubes, behave alike; they suffer no change on gentle heating, but when the temperature is sufficiently high to decompose the chemical molecules, the crystals break up into fine powder or dust, which is carried along by the escaping vapors and deposited for a considerable distance along the sides of the tubes. In addition to water, $\mathrm{SO}_{2}$ and $\mathrm{SO}_{3}$ are copiously given off during decomposition. In the case of natrojarosite, and the same would doubtless hold true for the Na-K-alunite, it is found that after ignition one-fourth of the sulphate radicle has been retained by the alkali metal, and may be extracted by water. In the case of plumbojarosite, bowever, all of the sulphate radicle is expelled by ignition, doubtless because the ferric-oxide present serves to decompose any lead sulphate which might have a tendency to form. Anglesite, $\mathrm{PbSO}_{4}$, when heated alone in a closed tube suffers no decomposition, but when finely triturated with limonite and heated, acid water is given off. Finely powdered natrojarosite and plumbojarosite are slowly but completely soluble in boiling hydrochloric acid. Plumbojarosite when fused with-sodium carbonate on charcoal yields globules of lead and a coating of lead oxide. 
It has seemed to the writers best to designate the new compounds described in this article as natrojarosite and plumbojarosite, the names signifying their relation to a well-known species. Other members of this group will doubtless be found, and the name "natroalunite" might be employed to designate the two varieties of alunite from Colorado mentioned on page 37, where the proportion of the soda to the potash molecule is $7: 4$. It is highly probable that a series of alunite-jarosite compounds could be made artificially.

It is with pleasure that the writers acknowledge their indebtedness to Messrs. Turner and Porter for calling attention to the interesting compounds described in this article. 


\title{
MINERALS FROM THE CLIFTON-MORENCI DIST'RIC'T', ARIZONA.
}

\author{
By W. Lindaren and W. F. Hillebrand.
}

In 1902 an examination was made of the Clifton-Morenci sopper district in Arizona. Study of the collections proved the presence of several interesting minerals, a brief account of which is here given. The copper deposits at Clifton and Morenci consist partly of irregular or tabular bodies of oxidized ores in Paleozoic limestones, partly of chalcocite ores connected with fissure veins in a granite-porphyry or in the same limestones.

\section{CORONADITE.}

On the dump of a small shaft on the west end of the Coronado vein, three-fourths of a mile west of Horseshoe shaft, fairly large amounts of a dark metallic mineral were found intimately intergrown with quartz and decomposing into limonite. The vein at this end shows no copper minerals, but is said to contain some gold, and its surface ores are reported to have been worked in an arrastre in the early days of the camp. In color this mineral is black and its structure is delicately fibrous. The hardness is about 4 and the streak black with brownish tinge.

A thin section proves it to be opaque, and in reflected light its fibrous and homogeneous structure is well brought out. It cements angular quartz grains and its secondary nature is clearly indicated. In general aspect it is not unlike psilomelane. A preliminary examination showed that it contained the oxides of lead and manganese. As it did not seem to correspond to any known mineral species, an analysis was made, after a partial mechanical separation. The results were as follows:

Long-continued efforts to procure pure material for analysis by the use of heavy solutions were not attended with success. The ultimate product of specific gravity, 5.246 at $22^{\circ}$, yielded on decomposition by hydrochloric acid a residue of from 6 to 7 per cent, which consisted mainly of silica, with a small amount of alumina, etc. Its presence would not have mattered much had it been quite indifferent to acids, but its partial solubility, as shown by the varying amounts undissolved on different trials, and similar varying amounts of alumina and perhaps 
other minor ingredients found in solution, renders the calculation of molecular ratios not altogether certain in all cases. The composition as found is:

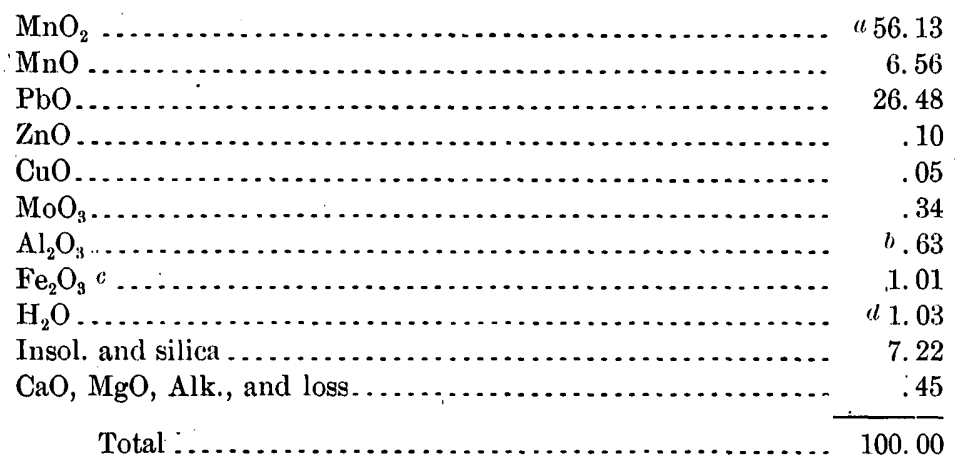

The material available did not permit the quantitative determination of the vanadium, which may be present in rather more than a mere trace, but neither it nor the phosphorus can influence materially the ratios given below. The vanadium would be effective in two ways: (1) by requiring a base for its neutralization, if existing as an acid constituent, and (2) by liberating chlorine when acted on by hydrochloric acid, and thus affecting the values found for peroxide oxygen. If the iron exists in the ferrous state, it too would affect the values found for the peroxide oxygen, and consequently for both the oxides of manganese. Assuming it to so exist and applying the proper corrections, also deducting from the lead oxide an equivalent for the molybdenum, assuming its existence as molybdate of lead, the following are the results:

\begin{tabular}{|c|c|c|}
\hline $\mathrm{MnO}_{2}$ & $\begin{aligned} 56.68 \div 87.0 & =0.6515 \\
6.11 \div 71.0 & =.0861)\end{aligned}$ & $=3.00$ \\
\hline $\mathrm{PbO} \ldots$ & $26.96 \div 222.9=.1165$ & \\
\hline $\mathrm{FeO} \ldots$ & $.91 \div 72.0=.0126\}$ & $0.217=1.00$ \\
\hline $\mathrm{ZnO} \ldots$ & $.10 \div 81.0=.0012$ & \\
\hline $\mathrm{CuO} \ldots \ldots \ldots \ldots$ & $.05 \div 79.0=.0006$ & \\
\hline $\mathrm{H}_{2} \mathrm{O} \ldots \ldots \ldots \ldots \ldots$ & $1.03 \div 18.0=.0572$ & $=.264$ \\
\hline
\end{tabular}

a Mean of 56.10 and 56.16. Total $\mathrm{Mn}$ as $\mathrm{MnO}$ from $\mathrm{MnSO}_{4}, 52.38$ per cent. Peroxide oxygen, 10.31 per cent.

$b$ With a little $\mathrm{TiO}_{2}, \mathrm{P}_{2} \mathrm{O}_{5}$, and $\mathrm{V}_{2} \mathrm{O}_{5}$.

$c$ State of oxidation not known.

d Nothing at $100^{\circ}$, only 0.14 per cent below $200^{\circ}$. 
If the mineral is to be regarded as anhydrous, the comparatively simple formula $\mathrm{R}^{\prime \prime}\left(\mathrm{Mn}_{3} \mathrm{O}_{7}\right)$ " satisties the above ratio, and it may be written structurally.

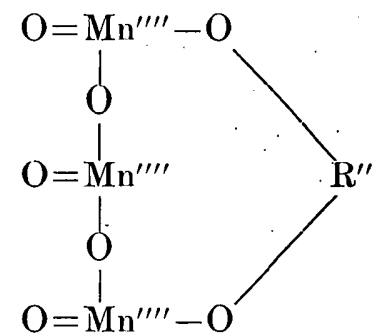

in which $\mathrm{R}^{\prime \prime}=\mathrm{Pb}^{\prime \prime}$ or $\mathrm{Mn}^{\prime \prime}$. This is to be regarded as a saturated salt of one of the numerous possible derivatives of ortho-manganous acid that may be derived from it by removal of water, in the present case as follows:

$$
3 \mathrm{H}_{4} \mathrm{MnO}_{4}-5 \mathrm{H}_{2} \mathrm{O} \doteq \mathrm{H}_{2} \mathrm{Mn}_{3} \mathrm{O}_{7}
$$

An acid of the same empirical formula would result by removal of two molecules of water from three of metamanganous acid, $\mathrm{H}_{2} \mathrm{MnO}_{3}$.

It is probably best to rest for the present content with the above relatively simple formula and to regard the water found as due to incipient alteration. But if the water is to be considered as wholly or in part essential, and furthermore constitutional-and this may very well be the proper view to take-then the formula becomes much more complex, namely, $\mathrm{R}_{4}{ }^{\prime \prime} \mathrm{H}_{2}\left(\mathrm{Mn}_{12} \mathrm{O}_{29}\right)$, when none of the water is allotted to the foreign matter. This formula is still referable graphically to a more highly condensed manganous acid, and a number of isomers would be possible.

Such intricate formulas as this should not cause the least surprise, however unlikely they may at first appear to be. The great number of manganites in varying degrees of saturation and hydration observed in nature and prepared artificially, some of them of even greater complexity than the above, are certainly not all mixtures of only a few simply constituted molecules. A very short study of the graphic formula corresponding to the above empirical formula $\mathrm{R}_{4}{ }_{4} \mathrm{H}_{2}\left(\mathrm{Mn}_{12} \mathrm{O}_{29}\right)$ will show what a vast number of closely related bodies are theoretically producible by hydrating the molecule step by step or by adding to or reducing the number of bivalent atoms or substituting for them those of another valence. Similar varieties in great number would be derivable from other condensed manganous acids of both higher and lower orders, and it is plain that because of the very slight differences in percentage composition between many of them it is almost as hopeless to expect analysis to reveal the exact empirical formula in the majority of cases as it is for the enormously complex albuminous 
bodies of organic chemistry. This is especially true because in so many cases the mineral manganites described are far from being homogeneous species. They are either mixtures of -two or more of these closely related coniplex molecules or else are contaminated by foreign bodies. It is not surprising, then, that so many compounds of uncertain formula that may be regarded as salts of manganous acid have been prepared in the laboratory or are found in nature. From the known tendency of these bodies to form under laboratory conditions which may very well be repeated in their general character in nature, it is to be expected that a vast number of mineral manganites should exist, and it ought rather to excite surprise than otherwise. if two or more are not formed simultaneously from the same solution. This, together with inherent difficulties of analysis, would offer a simple explanation of the fact that so few of the analyses made lead to rational formulas. If formed from solution, their original state might well be one of hydration either as regards water of crystallization or of constitution. The temperature at which the water is expelled in the present case indicates constitutional water.

Our search of the literature has not revealed a native manganite carrying a high percentage of lead, although artificial compounds have been prepared. For this reason, and because of its distinctly crystalline character, the present mineral seems worthy of a specific name. The one we propose is coronadite, after the famous explorer of that portion of the American continent from which the Territories of New Mexico and Arizona have been formed.

\section{CHALCOCITE.}

The cuprous sulphide $\left(\mathrm{Cu}_{2} \mathrm{~S}\right)$ is very common in the Clifton district; in fact, it constitutes at present the principal valuable mineral in the ores. It occurs chiefly intergrown with pyrite, in the altered porphyry, as disseminated grains or as solid seams or veins which rarely exceed 2 or 3 feet in thickness. It is never crystallized but has ordinarily an earthy or sooty appearance and black color; scratching with a knife reveals its semisectile character and metallic luster. In a few small massive veinlets the normal metallic luster and dark-gray color appear on fractures; a fibrous or columnar structure of the mineral is known on small seams in shale from the Montezuma mine. The mineral prefers porphyry, and the great bodies of ore now worked all occur in this rock; but it is not entirely unknown from the irregular deposits in limestone generally carrying cuprite and copper carbonates. A partial analysis of massive chalcocite from the Montezuma mine, Morenci, gave 96 per cent $\mathrm{Cu}_{2} \mathrm{~S}$ and 2.4 per cent $\mathrm{FeS}_{2}$, the latter probably mechanically admixed.

The chalcocite is everywhere, in this district, a secondary mineral 
formed by the replacement of pyrite by means of descending solutions of cupric sulphate. The deposition of the mineral was accompanied by the formation of quartz, chalcedony, and kaolin. In the porphyry the chalcocite ore along the veins begins 100 to 200 feet below the surface and continues to a depth of 400 feet, or even more, when it is usually replaced by pyrite, chalcopyrite, and zinc blende.

\section{WILLEMITE.}

This rare silicate of zinc $\left(\mathrm{Zn}_{2} \mathrm{SiO}_{4}\right)$ was found by $\mathrm{Mr}$. Boutwell in the form of very small grayish crystals on a fragment of garnet rock in the Modoc open cut, on the north side of Modoc Mountain. These crystals were identified by Messrs. Pirsson and Penfield, of Yale University, who state that the stout hexagonal prisms look exactly like those from the original locality at Moresnet.

\section{CALAMINE.}

Small transparent orthorhombic crystals of calamine $(\mathrm{ZnOH})_{2} \mathrm{SiO}_{3}$ were identified on a specimen of decomposed garnet rock from the Shannon mine, just above the lime quarry.

\section{DIOPTASE.}

The silicate of copper, dioptase $\left(\mathrm{H}_{2} \mathrm{CuSiO}_{4}\right)$ has been found at only a few localities. Very beautiful specimens, which, however, are by

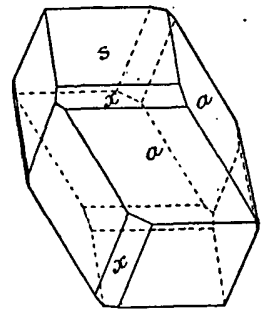

Fig. 3.-Dioptase. no means common, have long been known from the classic locality, the Kirghese Steppes, Russia, and more recently from the French Kongo State, Africa. Dioptase is seldom found in the United States, the only recorded occurrences being at the Bon Ton mines, Chase Creek, near Clifton, Ariz., noted by R. C. Hills, ${ }^{i}$ and from near Riverside, Pinal County, Ariz., noted by W. B. Smith. ${ }^{b}$ Well crystallized specimens of this mineral were found on an old dump of the Stevens group of mines, on the west side of Chase Creek, near Garfield Gulch. They occurred in a small chimney of chrysocolla ore in limestone, now worked out, and the locality is believed to be the same as that described by Mr. Hills. The dioptase crystals were submitted to Prof. S. L. Penfield, who remarks on them as follows:

The crystals, measuring from 1 to $2 \mathrm{~mm}$. in diameter, occur closely grouped together, lining cavities in a brown ferruginous gangue impregnated with amorphous green material which is probably chrysocolla. The color of the dioptase is a beautiful emerald-green. The habit of the crystals, shown by the accompanying figure, is that which is most commonly observed and is especially characteristic for dioptase; prism of the second order $a(11 \overline{2} 0)$, terminated chiefly by the rhombohedron of the first order $s(02 \overline{2} 1)$ and wiih small faces of the rhombohedron of the third order $x$ 
(1341.). As is common on this species, the prismatic faces are vicinal and the $s$ and $x$ faces are striated parallel to their mutual intersection edges; hence the crystals are not suited for giving accurate measurements of the angles with the reflection goniometer. One crystal was measured, and the angles of one of the rhombohedral zones, given below, are sufficiently close to the calculated values to establish the identity of the forms.

$$
\begin{array}{lrrrr} 
& & \text { Measured. } & \text { Calculated. } \\
\text { a. } x, & 11 \overline{2} 0 & 13 \overline{4} 1=28^{\circ} 55^{\prime} & 28^{\circ} 48^{\prime} \\
s s^{\prime}, & 02 \overline{2} 1 & \overline{2} 021=83^{\circ} 48^{\prime} & 84^{\circ} 33^{\prime} \\
s^{\prime} a^{\prime \prime}, & \overline{2} 021 & \overline{1} 120=48^{\circ} 18^{\prime} & 47^{\circ} 43^{\prime}
\end{array}
$$

By crushing some of the material, embedded in oil under a cover glass, and examination in convergent polarized light, occasional fragments were found which gave a normal uniaxial interforence figure, with numerous rings indicating high birefringence. The character of the birefringence was found to be positive. Thus in all of its crystallographic and optical relations the material studied is like typical dioptase from other localities.

\section{) CHRYSOCOLLA.}

This mineral $\left(\mathrm{CuSiO}_{3}+n \mathrm{H}_{2} \mathrm{O}\right)$ occurs very commonly in the oxidized part of the deposits, but does not, except in some cases, constitute an important ore. On the whole, it is more abundant in the deposits in porphyry and granite than in those contained in limestone. The usual bluish green or dirty green colors and conchoidal fracture characterize it. It occurs in seams or coatings at many of the mines-abundantly in the Mammoth mine on contact fissure between porphyry and limestone; at several prospects on the Stevens group in Chase Creek near Garfield Gulch; in the Terazas fissure vein in porphyry, near Metcalf; at the Metcalf mines and many of the prospects between that place and Morenci; at the Modoc open cut, Morenci. Technical analyses of chrysocolla ore from Terazas mine by the Arizona Copper Company gave-

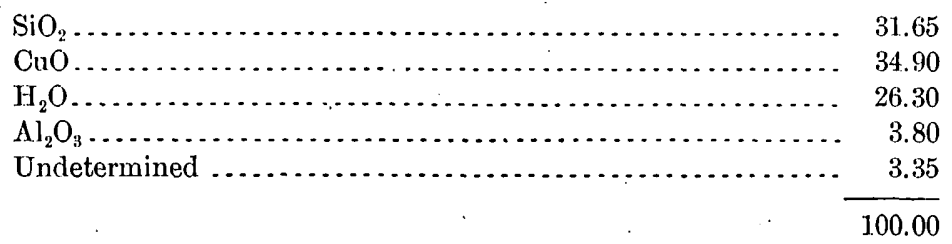

Normal chrysocolla should have 34.2 per cent $\mathrm{SiO}_{2}, 45.2$ per cent $\mathrm{CuO}$, and 20.5 per, cent $\mathrm{H}_{2} \mathrm{O}$, but the analyses show great divergency, many probably being mixtures. Moreover, what has been called chrysocolla probably includes two mineral species.

The optical characteristics of chrysocolla seem imperfectly known. Dana states that it is cryptocrystalline, while many other text-books, notably one issued in 1902 by Professor Miers, call it "amorphous."

In most cases the mineral indeed seems cryptocrystalline with bluishgray colors of interference, but this is by no means universal.

Chrysocolla from the Modoc open cut appears as mammillary crusts 
of bluish-green color on "copper-pitch ore." The latter is isotropic and undoubtedly a distinct mineral from the chrysocolla, of brown color in varying tints, some of it opaque and showing evidence of concentric deposition. On top of the chrysocolla are thin crusts of quartz and some calcite. The chrysocolla has three different structural forms, as seen under the miscroscope: (1) The dominant mass is a cryptocrystalline to microcrystalline aggregate of particles with high birefracting index; (2) very fibrous and felted aggregates of same substance giving undulatory effects between crossed nicols and medium high colors; (3) fibrous crusts on top of 1, or also in thin layers between masses of 1 , the individuals having such a remarkably parallel orientation that the aggregate of them appears almost like single crystals between crossed nicols, with black shadows sweeping across them when the table is turned. The extinction is parallel to the fibers, double refraction strong, about like augite, character negative. The same optical characteristics were repeatedly observed in thin sections of chrysocolla from Metcalf and other places. Reniform deposits were sometimes noted, the center of cryptocrystalline material coated with coarsely fibrous and highly birefringent material.

Sections from the Coronado and Metcalf mines often showed pseudomorphs of pyrite consisting of a shell of limonite with kernel of fibrous chrysocolla.

The observations of Jannettaz ${ }^{a}$ on chrysocolla from Boleo, Baja California, Mexico, led to the same results as described above, but seem generally to have been overlooked by editors of text-books.

\section{COPPER-PITCH ORE.}

Under this old German name is described a dark brown to black substance, sometimes dull but generally with glassy to resinous luster; hardness about 4; streak dark brown. It occurs among the products of oxidation of the deposits in limestone, as at the Detroit and Longfellow mines and Modoc open cut at Morenci, and is associated with azurite, malachite, and chrysocolla, often inclosing these minerals or replacing in branching veinlets, together with azurite, a shale-like mass, probably largely composed of kaolin. In thin section it is sometimes opaque, but often also translucent, gradual transitions obtaining in the same section, and occurs in irregular or concretionary masses, often containing small embedded crystals of a doubtful mineral, possibly a silicate of zinc. Between crossed nicols the translucent mineral always proves entirely isotropic and, except for varying depth of color and the small crystals mentioned, entirely homogeneous. 
A rough preliminary analysis of selected pitch black material from the Detroit mine gave

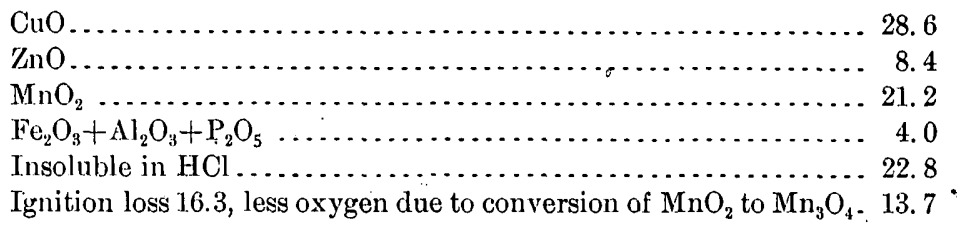

98.7

Similar material surmounted by crusts of chrysocolla from the Modoc open cut contained much $\mathrm{MnO}_{2}$, with a good deal of $\mathrm{CuO}$ and $\mathrm{ZnO}$, and is thus evidently the same substance. Manganese is largely but not certainly wholly present as $\mathrm{MnO}_{2}$. The insoluble portion consists of silica, is wholly separated by acid without need of evaporation, and is nearly all soluble in dilute potassium hydroxide. It is not possible to say whether silica is in combination or as opal, but it can not be present in any other form.

Most of these copper-pitch ores, known from many districts, have been described as impure chrysocolla. As shown by the optical characteristics, they are not, however, a mixture, and they certainly do not contain any chrysocolla, the characteristics of which are very different. They probably represent a series of closely related compounds, the chemistry of which has not yet been fully elucidated. Prof. G. A. Koenig ${ }^{a}$ describes a similar mineral with the same isotropic character from Bisbee, and names it melanochalcite. Its composition is different, since it contains

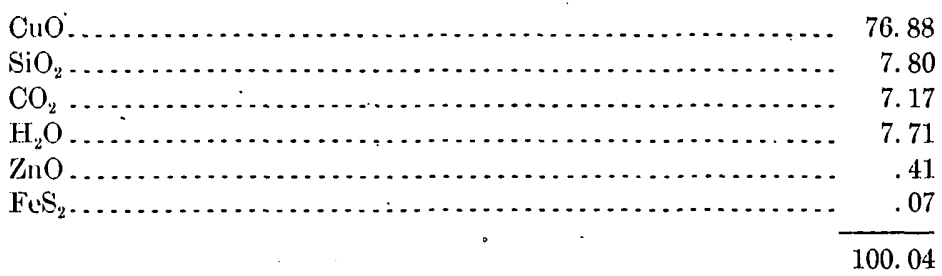

Professor Koenig considers it most probably a basic salt of an orthosilico-carbonic acid. No carbon dioxide was found in the Morenci minerals. In conclusion it would seem that the chemistry of these copper-pitch ores would bear further examination.

\section{MORENCITE.}

In a lime shale on the intermediate level of the Arizona Central mine, Morenci, 200 feet below the surface, brownish or greenish spreading mases were found, containing brownish yellow, silky fibrous seams. The inclosing matcrial consists largely of the same material 
as the seams, but impure and mixed with a little chlorite and pyrite. The whole bears evidence of being a product of oxidation of some contact metamorphic mineral.

The fibrous mineral on the seams forms a felted aggregate as seen under the microscope, but it is well individualized and contains few impurities except a little pyrite and chlorite. The minute fibers are brownish yellow and slightly pleochroic, being darker when parallel to the principal section (opposite the behavior of biotite); the birefringence is strong and extinction strictly parallel to the fibers. No mineral corresponding to this has been described, but, although its individual character is beyond doubt, the analysis does not lead to a satisfactory formula. The material for the analysis was picked out carefully under the lens and examined under the microscope it proved satisfactorily pure.

The analysis afforded the results of the first column of figures below. In deducing the molecular ratios of the second column there has been deducted sufficient lime to form apatite with the phosphoric oxide.

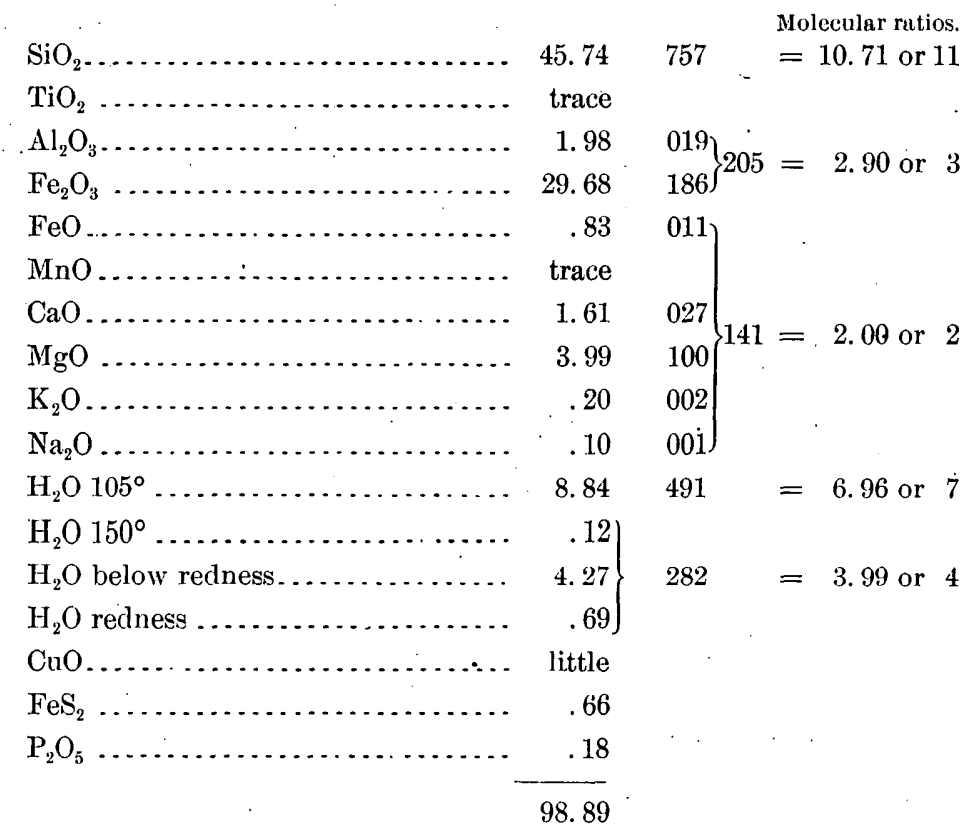

It would seem from the temperatures at which the water is driven off that this must exist in two conditions, and that four-elevenths of it must be held more securely than the remaining seven-elevenths. The attempt to account for four molecules of water as constitutional, however, led to no simple or seemingly probable formula, whereas if. all water is excluded the ratio is that of a metasilicate- $\mathbf{R}_{2}{ }_{2} \mathbf{R}^{\prime \prime \prime}{ }_{6}$ $\left(\mathrm{SiO}_{3}\right)^{\prime \prime}{ }_{11}$. On the other hand, to include the whole of the water as essential to the silicate molecule, for which there is little ground in 
view of the ease with which most of it is expelled, leads to an orthosilicate ratio- $\mathrm{R}_{22}^{\prime} \mathrm{R}_{2}{ }_{2} \mathrm{R}^{\prime \prime \prime}{ }_{6}\left(\mathrm{SiO}_{4}\right)^{\prime \prime \prime \prime}{ }_{11}$.

On the whole, considering also the bad summation of the analysis, it is more rational to regard the mineral as a hydration product of an original metasilicate molecule than to attempt to construct a complex formula which could have but a very doubtful value. As the mineral is not a mixture, but is optically well individualized, we have, after some hesitation, thought best to designate it by the name morencite, derived from the locality in which it was found.

\section{LIBETHENITE.}

This hydrous, basic phosphate of copper $\left(\mathrm{H}_{2} \mathrm{Cu}_{4} \mathrm{P}_{2} \mathrm{O}_{10}\right)$ was found 30 feet below the adit level of the Coronado lode, in the main shoot. It is a matter of interest to record its occurrence, for this rare mineral has never before been noted in the United States. It occurs in small crystals, less than $1 \mathrm{~mm}$. in length, deposited in cavities and seams.in a quartzite gangue. The mineral was identified by Prof. S. L. Penfield, who also kindly measured and figured the crystals. Professor Penfield describes the occurrence as follows:

The only associated minerals are occasional clusters of minute quartz crystals and small tufts of radiated malachite needles. The color of the libethenite varies from light to dark olive-green, depending upon the size of the crystals. The habit of the crystals, as shown by the accompanying illustration, is a combination of the prism $m(110)$ and brachydome $e(011)$, which is exactly like that commonly observed on libethenite from foreign localities. On an occasional crystal

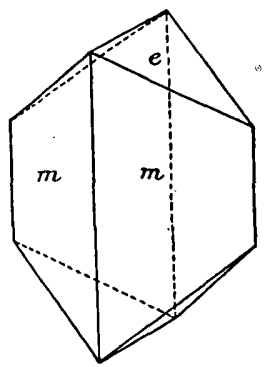

Fig. 4-Libethenite. the brachypinacoid $b(010)$ was also observed. Although the crystals are brilliant, the faces are generally vicinal and give uncertain or multiple reflections of the goniometer signal. The best reflections were obtained from the faces of the dome $e$, and three measurements of $e \quad e^{\prime}, 011 \quad 0 \overline{1} 1$ gave $69^{\circ} 52^{\prime}, 70^{\circ} 18^{\prime}$, and $70^{\circ} 14^{\prime}$. The last measurement, obtained from the best reflections, is close to the value, $70^{\circ} 8^{\prime}$, obtained by Rose. The best measurements of the prismatic angle gave $m \wedge m^{\prime \prime \prime}$, $110 \wedge 1 \overline{1} 0=87^{\circ} 11^{\prime}$, which, considering the vicinal character of the prismatic faces, is reasonably close to the value of Rose, $87^{\circ} 40^{\prime}$, as given in Dana's Mineralogy. A small crystal resting on a prismatic face, when examined in convergent polarized light, showed an optical axis nearly in the center of the field, with the dark bar running at right angles to the vertical axis, thus indicating that the optical axes are in the plane of the base, as determined by Des Cloizeaux. The presence of copper, water, and phosphoric anhydride was determined by chemical tests.

A more detailed search would probably reveal small quantities of phosphates from other mines near Morenci. They are certainly not abundant. 


\section{BROCHANTITE.}

This basic sulphate of copper $\left(\mathrm{H}_{6} \mathrm{Cu}_{4} \mathrm{SO}_{10}\right)$ is usually supposed to be one of the rarer minerals. It was, however, discovered at a few places near Metcalf and Morenci, in well-developed crystals, and this led to a systematic microscopic examination of the green ores, hitherto supposed to be malachite. The result was surprising, as the mineral was proved to be of extremely common occurrence, mostly intergrown with malachite, which had effectively masked its presence. It is believed that a careful examination of many so-called malachites from other districts will disclose the overlooked importance of brochantite as a copper ore.

Brochantite is frequently crystallized in the short but stout rhombic prisms combined with dome and brachypinacoid characteristic of the species. Needle-shaped and flat crystals are more rare. The crystals are usually of small size and frequently microscopic. It occurs as lighter or darker emerald-green crusts on limonite or sericitized porphyry from the red ore body in the Shannon mine, from the Metcalf mines and many other places; as fine-grained aggregates in altered porphyry at the Shannon mine, near the surface, constituting valuable ore with as much as 30 per cent copper; from croppings of the King vein, filling seams and coating porphyry fragments as flat pieces or even foils with almost pearly luster; from the croppings of the Copper Queen mine between Morenci and Metcalf, here as flat stellar aggregates of bluish green foils; at many places near Morenci, as, for instance, Copper Mountain and Montezuma mines, at the latter locality replacing chalcocite. It would probably not be found absent from any mine. in the district containing oxidized copper ores. Malachite often develops later than the brochantite.

On the whole, the mineral is most abundant in fissure veins in porphyry, though also occurring in the irregular deposits in limestone.

Brochantite has an excellent cleavage parallel to the brachy pinacoid. The macropinacoid is the axial plane and the acute bisectrix is seen emerging in cleavage foils. Pleochroism very slight. Birefringence much lower than malachite, about equal to that of augite. This, as well as the absence of twins, distinguishes brochantite from malachite. The reaction for sulphuric acid is of course a valuable aid.

\section{SPANGOLITE.}

This peculiar mineral $\left(\mathrm{H}_{18} \mathrm{Cu}_{6} \mathrm{AlClSO}{ }_{19}\right)$, essentially a highly basic chloro-sulphate of copper and aluminum, was discovered and described by Prof. S. L. Penficld ${ }^{a}$ about fifteen year's ago. The specimen came from some point within 200 miles of Tombstone, Ariz., and probably 
from one of the great copper camps of the Territory. Somewhat later: it was identified by Prof. H. A. Miers on two specimens from Cornwall, England, but the American locality has not yet been found. It is, therefore, a matter of interest to record its discovery on some specimens from the Metcalf mine of the Arizona Copper Company, taken from the workings in the great open cut not more than 100 feet below the surface. These specimens consist of white sericitized graniteporphyry, in part silicified, and traversed by veinlets and irregular masses of cuprite; the cuprite contains native copper and is covered by crusts of malachite, brochantite, and chrysocolla. A soft and scaly bluish-green coating on the chrysocolla proved to consist of microscopical hexagonal crystals or cleavage foils, remaining dark between crossed nicols. The mineral was identified as spangolite, a determination in which Professor Penfield concurred. No measurable crystals were found, and the mineral is very inconspicuous. It is difficult, if not impossible, to obtain material entirely free from other minerals.

Selected bluish flakes from this specimen gave tests for water, and the sulphate and chlorine ions, besides copper. There was too little of this pure material to permit of a test for alumina, but the mixed copper minerals composing the greater part of the specimen showed the presence of this body. It seems therefore probable on these grounds alone that the bluish flakes are spangolite. Vanadium, phosphorus, and arsenic are absent.

The closed-tube reactions of the mixed copper minerals are very striking. Water is given off first. Then appear's suddenly a white sublimate $\left(\mathrm{AlCl}_{3}\right.$ ? $)$ near the assay, which seems to form or at once change to minute colorless drops. This deposit can be driven slowly up the tube, followed at its lower, sharply defined edge by dark yellowbrown drops $\left(\mathrm{CuCl}_{2}\right.$ ? $)$, which on cooling solidify to greenish crystalline aggregates, and the part of the tube between them and the assay shows under the lense delicate feathery crystallizations like frost markings on window panes. Down in the flame the glass becomes colored red $\left(\mathrm{Cu}_{2} \mathrm{O}\right.$ ?) and in pirts yellow. On charcoal the blowpipe flame is colored azure blue and at the same time green.

In order to compare the above closed-tube behavior with that of undoubted spangolite, a small fragment of the latter, offered by Professor Penfield, was tested. It gave water and then a white sublimate like the one above mentioned, followed by a dark olive-brown liquid, which on cooling passed through lighter sbades of color and solidified as a bright green ring. In general this behavior is very like that of the mixture under examination from Clifton.

\section{GERHARDTITE.}

The cliffs of granite-porphyry in the deeply eroded Chase Creek Canyon at Metcalf in many places show a conspicuous and extensive . bright green coating of some copper mineral, which, no doubt, is 
formed by the trickling of atmospheric waters over and through rocks containing a small percentage of copper. This is not surprising, for porphyry in this vicinity is altered throughout by quartz cementation and disseminated cupriferous pyrite. This "green paint," as it is frequently called, is not soluble in water, and more closely examined consists of small dark-green, roughly mammillary forms, coating the rock to a thickness of a few millimeters. Examination by the microscope fails to reveal any recognizable mineral in the cryptocrystalline mass.

Chemical examination led to the interesting result that the copper minerals present consist of a nitrate and a chloride, neither of which has been found elsewhere in the mines of the district. Detrital grains and some silica seem associated with these compounds. The nitrogen seems difficult to account for in the absence or scarcity of animal substances which might have yielded it. Possibly it is contained in the porphyry.

The closed-tube reactions of the copper minerals forming the mixture on this specimen are as stiriking in.their way as those of the mixture containing spangolite, described elsewhere. Water first appears, then brownish nitrous vapors, followed by a sublimate which is not very volatile, becomes black on further heating but on cooling yellow-brown. The glass at the bottom of the tube is often yellowbrown when cold. After some hours the sublimate nearly disappears or becomes greenish from absorption of water. If the water which condenses in the upper part of the tube on first applying heat is driven out by the flame; and the mouth of the tube is held in the flame, this is colored deep green by a volatile copper compound (chloride?). On charcoal the flame is azure blue and at the same time green. Vanadium is absent.

The mixture contains presumably the basic nitrate gerhardtite $\left(\mathrm{H}_{6} \mathrm{Cu}_{4} \mathrm{~N}_{2} \mathrm{O}_{12}\right)$ and a chloride which is perhaps atacamite. Spangolite, the chloride, can hardly be present, for the slight amóunt of $\mathrm{SO}_{3}$ shown by test does not seem sufficient to account for the large amount of chloride.

The only place from which gerhardtite has previously been identified is at Jerome mines in the central part of Arizona, associated with cuprite and malachite. It was discovered there by Messr's. H. L. Wells and S. L. Penfield. 


\title{
TWO 'IELLUURIUM MINERALS FROM COLORADO.
}

\author{
By W. F. Hillebrand.
}

\section{EMMONSITE (?) FROM A NEW LOCALITY.}

Messrs. F. L. Ransome and Waldemar Lindgren, of the Geological Survey, collected, in the W. P. H. mine at Cripple Creek, a green mineral which has been observed in other mines there, and which on examination in the laboratory showed close resemblance to the emmonsite described by the writer nearly twenty years ago." It differed from it, however, in outward appearance by assuming mammillary forms instead of crystalline plates. In its optical properties, so far as they were determinable, there is perhaps no positive disagreement with those reported for emmonsite. Mr. W. T. Schaller reports as follows:

There are two cleavages, one paralled to $b(010)$ and another parallel to a form in the orthozone. Axial plane parallel to $b(010)$. $\mathrm{Bx}_{\mathrm{a}}$ perpendicular to a cleavage face in the orthozone. 'The extinction on the clinopinacoid is inclined $25^{\circ}$ to $30^{\circ}$ to the vertical axis. $2 \mathrm{E}$ is approximately $40^{\circ}$. Double refraction medium, and the mineral nonpleochroic.

The gangue in which the specimens were found is granite and schist, close to their contact with a porphyritic breccia, in a vein pocket, at a distance of about 150 feet from the surface. Associated with it was very rich native gold ore and also tellurite, though neither of these was apparent on the few specimens that came to the laboratory.

Like emmonsite, the mineral melts at a low heat to a red-brown liquid, but, unlike it, gives on stronger heating only tellurous oxide with no trace of selenium or selenious oxide. Analysis confirmed the absence of selenium. Its density, too, differs from that of emmonsite, if the determinations in both cases on scanty material are to be depended on. After allowing for gangue, the original emmonsite was judged to have a density of at least 5 , while that of the present mineral is but little above 4.53 , after allowing for 24.44 per cent of gangue, consisting mainly of quartz, and to which the specific gravity of quartz was assigned.

In its appearance the present mineral would seem to resemble durdenite more than emmonsite, but the marked difference in water 
content differentiates it sharply from that mineral, durdenite yielding. over 10 per cent.

After deducting 22.44 per cent of gangue containing over 90 per cent of silica, three portions of from 0.15 to 0.20 gram net weight each gave the following results:

\begin{tabular}{|c|c|c|c|c|c|}
\hline & 1. & 2. & 3. & Mean. & Rutios. \\
\hline $\mathrm{TeO}_{2} \ldots \ldots \ldots \ldots$ & 70.83 & 71.80 & 70.20 & 70.71. & 3.16 \\
\hline $\mathrm{Fe}_{2} \mathrm{O}_{3} \ldots \ldots \ldots \ldots$ & 22.67 & 22.81 & 22.79 & 22.76 & 1. 00 \\
\hline $\mathrm{H}_{2} \mathrm{O}$ at $100^{\circ} \ldots \ldots \ldots \ldots$ & 4.68 & 482 & .21 & .21 & $\ldots \ldots \ldots$ \\
\hline $\mathrm{H}_{2} \mathrm{O}$ above $100^{\circ} \ldots \ldots \ldots \ldots$ & 4.08 & 4.82 & & 4.54 & 1. 77 \\
\hline $\mathrm{P}_{2} \mathrm{O}_{5} \ldots \ldots \ldots \ldots \ldots \ldots$ & ...... & .34 & - & .34 & $\ldots \ldots \ldots$ \\
\hline $\mathrm{Al}_{2} \mathrm{O}_{3} \ldots \ldots \ldots \ldots$ & $\ldots \ldots$ & .58 & .54 & .56 & 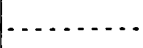 \\
\hline \multirow[t]{2}{*}{$\mathrm{SiO}_{2}$, etc. $a \ldots$} & & & $\cdots$ & .88 & . \\
\hline & & & $\cdots$ & 100.00 & $\ldots$. \\
\hline
\end{tabular}

a Includes alkalies, traces of magnesia and gold, and a small amount of a metal or metals precipitable by hydrogen sulphide whose identity could not be established.

Allowing the alumina to offset the $\mathrm{P}_{2} \mathrm{O}_{5}$, though it may belong to a soluble silicate or to the tellurite, and a small portion of iron be demanded for the $\mathrm{P}_{2} \mathrm{O}_{5}$, the ratios given in the final column result. They are as unsatisfactory as those afforded by the original emmonsite, which were for $\mathrm{Fe}_{2} \mathrm{O}_{3}$ to $\mathrm{TeO}_{2}, 1: 3.65$ in the original description and 1:3.75:1.82 for $\mathrm{Fe}_{2} \mathrm{O}_{3}: \mathrm{TeO}_{2}: \mathrm{H}_{2} \mathrm{O}$ if the supplementary determinations in Am. Jour. Sci., vol. 40, p. 81, 1899, are accepted. The presence of tellurite in association with the green mineral suggests a possible explanation of the failure to obtain a simple ratio, though such contamination was not noted in the material analyzed nor on the neighboring gangue. If this explanation is correct, however, the variation from the original emmonsite ratio becomes still more marked. Provisionally, the mineral may be regarded as emmonsite.

The above results are given in some detail, notwithstanding their inconclusiveness, because of the importance of accumulating data regarding the as yet small but interesting group of ferric tellurites, and inciting collectors and mining men to careful search for and preservation of further material for more extended study.

Thus far emmonsite, durdenite, and an unnamed mineral from Cripple Creek, described by Knight in Proc. Colorado Sci. Soc., vol. 5, p. 66, and affording likewise unsatisfactory ratios, comprise the list of natural ferric tellurites, the formula of no one of which can be regarded as established beyond question. 


\section{TETRADYMITE.}

Specimens received in the Survey laboratory from Mr. H. B. Trader and said to come from some locality near Whitehorn, Fremont County, proved to be tetradymite. They showed the mineral in masses of considerable size, which, although manifesting the eminent cleavage of tetradymite, were devoid of distinct evidences of crystal form. The specific gravity at $20^{\circ} \mathrm{C}$. was 7.816. Analysis afforded the following results:

\begin{tabular}{|c|c|c|c|c|c|}
\hline & 1. & 2. & 3. & Mean. & Atomic ratio. \\
\hline $\mathrm{Bi} \ldots . .$. & 52.00 & 52.30 & 52.13 & 52.14 & $0.2498=2.0$ \\
\hline $\mathrm{Te} . . . . . .$. & 46.62 & $468 ?$ & & 46. 62 & $.3651)$ \\
\hline Se.......... & a. 20 & 40.82 & & .20 & $.0025\}=2.98$ \\
\hline S.......... & .13 & .14 & & .14 & .0044 \\
\hline $\mathrm{Fe}_{2} \mathrm{O}_{3} \ldots \ldots \ldots \ldots \ldots$ & .22 & & & .22 & $\ldots \ldots \ldots$ \\
\hline \multirow[t]{2}{*}{ Insoluble ........... } & .15 & & .......... & .15. & $\cdots \cdots$ \\
\hline & & & & 99.47 & \\
\hline
\end{tabular}

a Approximate. 


\section{NOTES ON LAWSONI'TE.}

\section{By W. T. Schaller and W. F. Hillebrand.}

Crystals of lawsonite are very simple in their combinations, the common forms being the prism, base, and brachydome. Two habits occur-tabular crystals with $\{001\}$ and $\{110\}$ and crystals with the forms $\{110\}$ and $\{011\}$. The brachypinacoid and the brachydome $\{041\}$ also occur: A large number of crystals from the typical locality in Marin County, Cal., were collected by the writer and carefully examined with a hand lens for any additional forms. Only two new forms were determined.

The forms observed on the six crystals measured are:

$$
\begin{array}{rl}
c=0=001 & d=01=011 \\
b=0 \infty=010 & e=04=041 \\
m=\infty=110 & r=2=221 \\
& s=3=331
\end{array}
$$

\begin{tabular}{|c|c|c|c|c|c|c|c|c|c|c|c|}
\hline \multirow{2}{*}{ No. } & \multirow{2}{*}{ Letter. } & \multicolumn{2}{|c|}{ Symbol. } & \multicolumn{4}{|c|}{ Measured. } & \multicolumn{4}{|c|}{ Calculated. } \\
\hline & & Gidt. & Miller. & & & $\rho$ & & & & & \\
\hline 1 & $c$ & 0 & 001 & & & & $0 \dot{2}$ & $\begin{array}{c}\circ \\
\ldots\end{array}$ & ' & $\begin{array}{l}\circ \\
0\end{array}$ & \\
\hline 2 & $b$ & $0 \infty$ & 010 & 0 & 00 & 90 & 00 & 0 & $00^{\circ}$ & 90 & 00 \\
\hline 3 & $m$ & $\infty$ & 110 & 56 & 22 & 90 & 00 & 56 & 22 & 90 & 00 \\
\hline 4 & $d$ & 01 & 011 & 0 & 09 & 36 & 36 & 0 & 00 & 36 & 27 \\
\hline 5 & $e$ & 04 & 041. & 0 & 00 & 71. & 18 & 0 & 00 & 71 & 18 \\
\hline 6 & $r$ & 2 & 221. & 56 & 27 & 69 & 10 & 56 & 22 & 69 & $2 \bar{\gamma}$ \\
\hline 7 & $s$ & 3 & 331. & 56 & 22 & 76 & 21. & 56 & 22 & 75 & 58 \\
\hline
\end{tabular}

The angles measured, with those calculated for these forms, are quoted in the table following: 
The new pyramid $r=2=\{221\}$ is present on two crystals, the faces giving good reflections. Fig. 1 shows one crystal on which this form occurs.

The new pyramid $s=3=\{331\}$ is present on only one crystal and but one face of the form occurs. The relative size of the face is about the same as that of the preceding pyramid. The reflection was fair.

The brachydomes are usually deeply striated, rendering it difficult to determine with certainty any domes present. On two crystals reflections were obtained from two faces, measurements of which agree with the angles calculated for the form $\{034\}$. The form is rather uncertain and is not included with the others.

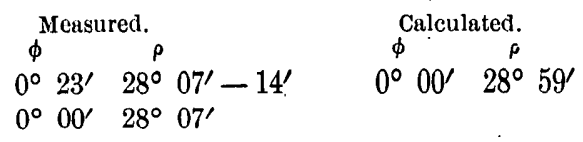

The combinations observed on the crystals measured are shown in the following table:

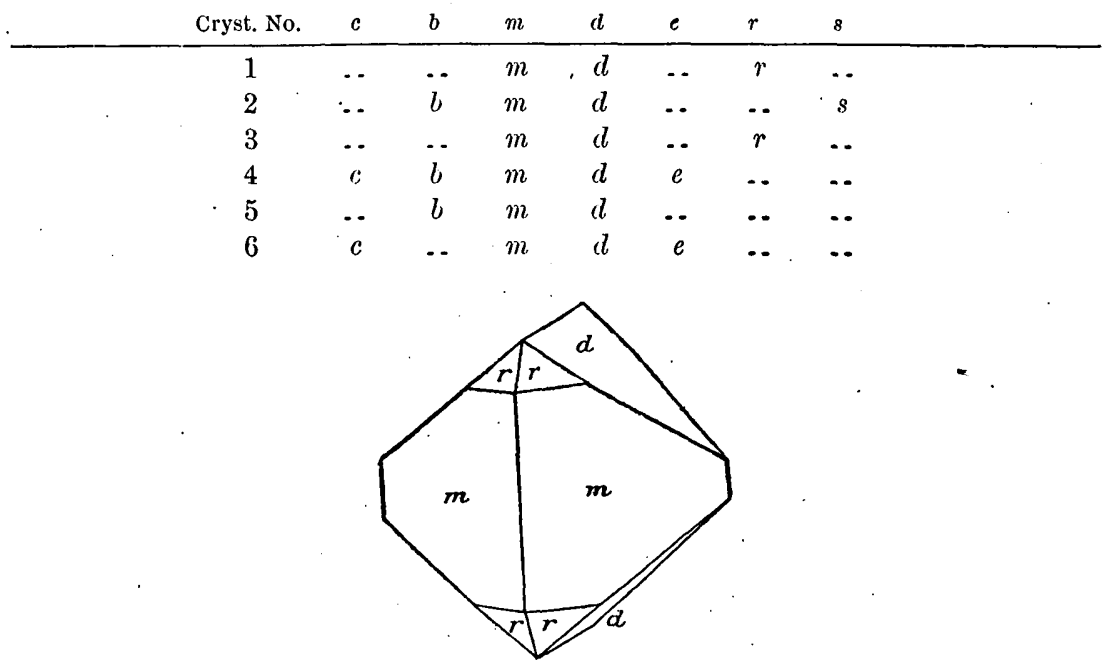

Fig. 5.-Lawsonite.

The following table is a calculation of the two new forms corresponding to the tables given in Goldschmidt's Winkeltabellen.

\begin{tabular}{|c|c|c|c|c|c|c|c|c|c|c|c|c|}
\hline No. & $\begin{array}{l}\text { Let- } \\
\text { ter. }\end{array}$ & $\begin{array}{c}\text { Sym- } \\
\text { bol. }\end{array}$ & $\begin{array}{l}\text { Mil- } \\
\text { lér. }\end{array}$ & $\phi$. & $\rho$. & $\xi_{0}$. & $\eta_{0}$. & $\xi$. & $\eta$ & $\underset{(x: y) .}{\stackrel{x}{x}}$ & $y$. & $\begin{array}{c}d= \\
\operatorname{tg} \rho .\end{array}$ \\
\hline 6 & $r$ & 2 & 221 & $\begin{array}{cc}\circ & 1 \\
56 & 22\end{array}$ & $\begin{array}{cc}\circ & 1 \\
69 & 27\end{array}$ & $\begin{array}{cc}\circ & \prime \\
65 & 45\end{array}$ & $\begin{array}{cc}\circ & 1 \\
55 & 54\end{array}$ & $\begin{array}{cc}\circ & 1 \\
51 & 13\end{array}$ & $\begin{array}{cc}\circ & 1 \\
31 & 14\end{array}$ & 2.2204 & 1.4770 & 2.6667 \\
\hline 7 & $s$ & 3 & 331 & $\begin{array}{ll}56 & 22\end{array}$ & 7558 & $73 \quad 17$ & 6542 & 5353 & $32 \quad 30$ & 3.3306 & 2.2155 & 4.0001 \\
\hline
\end{tabular}


Material carefully purified by the Thoulet solution followed by repeated electromagnetic extraction, and having then a specific gravity of 3.121 at $25^{\circ}$, gave the following results on analysis: ${ }^{a}$

\begin{tabular}{|c|c|c|c|}
\hline . & & $\begin{array}{l}\text { Molecular } \\
\text { ratio. }\end{array}$ & $\begin{array}{l}\text { Calculated for } \\
\text { the formula } \\
\mathrm{H}_{4} \mathrm{CaAl}_{2} \mathrm{Si}_{2} \mathrm{O}_{10} \text {. }\end{array}$ \\
\hline $\mathrm{SiO}_{2} \ldots \ldots$ & 38.45 & 1.98 & 38.34 \\
\hline $\mathrm{TiO}_{2}$ & .38 & & \\
\hline $\mathrm{Al}_{2} \mathrm{O}_{3} \ldots \ldots \ldots \ldots \ldots \ldots \ldots \ldots$ & 31.35 & & \\
\hline $\mathrm{Fe}_{2} \mathrm{O}_{3} \ldots \ldots \ldots \ldots \ldots \ldots \ldots \ldots \ldots$ & .86 & .97 & 32.44 \\
\hline $\mathrm{FeO} \ldots \ldots \ldots \ldots \ldots \ldots \ldots \ldots \ldots \ldots$ & .10 & & \\
\hline $\mathrm{MnO} \ldots \ldots \ldots \ldots$. & faint tr. & & \\
\hline $\mathrm{CaO} \ldots \ldots \ldots$ & 17.52 & & \\
\hline $\mathrm{MgO} \ldots \ldots$. & .17 & 1.00 & 17.80 \\
\hline 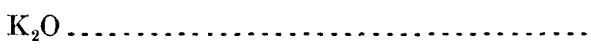 & .23 & $\therefore$ & \\
\hline 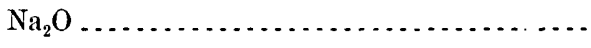 & .06 & & \\
\hline $\mathrm{H}_{2} \mathrm{O}$ (ignition) $\ldots \ldots \ldots \ldots \ldots \ldots \ldots \ldots \ldots$ & 11.21 & 1.95 & 11.42 \\
\hline Total ... & 100.33 & & 100.00 \\
\hline
\end{tabular}

Titanium is not considered in the ratio because probably present as an inclusion of rutile or titanite. If the latter, the ratio would perhaps approximate still more closely to the theoretical than it does. The agreement with the formula deduced by Ransome and Palache from their rather widely differing analyses is very satisfactory. The behavior of the mineral before the blowpipe is somewhat different from that given by those authors, or rather their statement needs amplification. On first applying the flame a splinter appears to fuse easily, as stated, and there is formed a blebby glass, or on larger splinters a porous sinter, but this fusing is only momentary, and it requires the highest heat attainable, under which the fragment emits quite an intense light, to produce a further softening and rounding of the edges. If a rather large splinter is held in the flame of the blowpipe, or in a small flame of a blast lamp, a very sudden and marked exfoliation is observed, but even the extruded points and edges do not fuse completely in the highest attainable heat. The semifused surface, however, appears dark on cooling, sometimes nearly black where the heat was most intense. In producing this exfoliation, if care is taken to apply the flame but for a moment, it has been noticed that a singularly shaped excrescence may shoot out from a point of the surface.

aConcerning this purified material, Doctor Ransome reports as follows:

"I should say the material is as pure as it is possible to get it. The grains are all lawsonite, but vary in individual purity. Some are perfectly clear. Others have minute inclusions, which appear in most cases to be solid particles but are too minute for identification. One of them, however, was suggestive of rutile. Some of the grains are slightly clonded with a yellowish stain which the microscope is unable to resolve into distinct particles. There are apparently a few fluid inclusions also." 


\title{
THE COMPOSITION OF YTTRIALITE, WITH A CRITICISM OF THE FORMULA ASSIGNED T'O THALÉNITE.
}

\author{
By W. F. Hillebrand.
}

In a paper describing the new yttrium silicate thalénite, ${ }^{a}$ the author, C. Benedicks, casts doubt on the formula assigned by Hidden and Mackintosh $^{b}$ to their mineral yttrialite from Llano County, Tex., for which they deduced the formula $\mathrm{R}_{2} \mathrm{O}_{3} 2 \mathrm{SiO}_{2}$ or $\mathrm{R}_{2} \mathrm{Si}_{2} \mathrm{O}_{7}$, in which $\mathrm{R}_{2} \mathrm{O}_{3}$ includes the sesquioxide equivalents of very considerable percentages of monoxides and dioxides. Benedicks would assign yttrialite to a group of which rowlandite is the prototype and to which he believes thalénite and kainosite belong, these being either plain basic salts of $\mathrm{H}_{6} \mathrm{Si}_{2} \mathrm{O}_{7}$ of the type $\mathrm{R}^{\prime \prime} \mathrm{R}^{\prime \prime}{ }_{4} \mathrm{Si}_{4} \mathrm{O}_{15}$ or derivatives in which the fifteenth oxygen atom is replaced by its equivalent in fluorine (rowlandite) or $\mathrm{CO}_{3}$ (kainosite), as showh below.

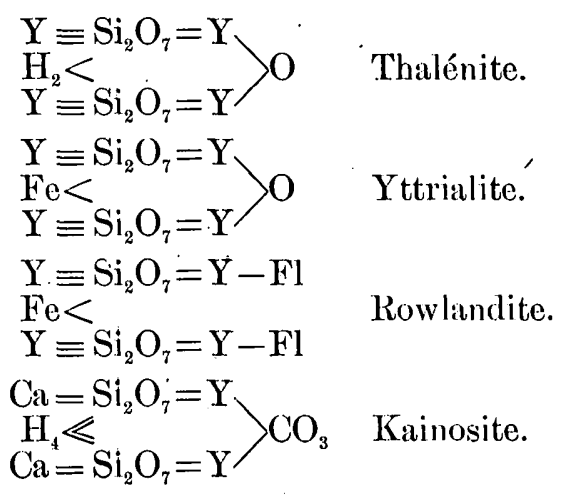

Benedicks says:

Dem Yttrialit, von Hidden and Mackintosh beschrieben, sollte die Formel $\mathrm{R}_{2} \mathrm{O}_{3}$, $2 \mathrm{SiO}_{2}$ zukommen, worin $\mathrm{R}$ hauptsïchlich Ytter- und Thorerde ist. Dabei wird aber ca. $4 \%$ Eisenoxydul in der Analyse vernachlïssigt. Wird dies nebst etwas Kalk und Bleioxyd mitgerechnet, so bekommt man die Formel $\mathrm{Fe}^{\prime \prime} \mathrm{O}, 2 \mathrm{R}_{2} \mathrm{O}_{3}, 4 \mathrm{SiO}_{2}$, analog mit der des Thalénits, welche besser die Zusammensetzung des Yttrialits wiedergibt, obgleich die Ubereinstimmung gar nicht gut ist. 
It is, however, not true that Hidden and Mackintosh neglected to take account of the ferrous iron, etc., of their analysis. It was regarded in the derivation of their enpirical formula $\mathrm{R}_{2} \mathrm{Si}_{2} \mathrm{O}_{7}$. How wholly unwarranted was the substitution by Benedicks of his formula for yttrialite is shown by the molecular ratio for $\mathrm{RO}: \mathrm{R}_{2} \mathrm{O}_{3}: \mathrm{SiO}_{2}$, which he gives as 1:2:4 instead of 1:3.25:7.42, as calculated by me from Mackintosh's figures, wherein for a sound reason I have converted his $\mathrm{UO}_{3}$ into $\mathrm{UO}_{2}$, thus throwing it with the $\mathrm{ThO}_{2}$, where it naturally belongs. The agreement is indeed "gar nicht gut."

Benedicks has made the grave mistake of counting Mackintosh's monoxide bases a second time, thus making a basic salt $\mathrm{R}^{\prime \prime} \mathrm{R}^{\prime \prime \prime}{ }_{4} \mathrm{Si}_{4} \mathrm{O}_{15}$ instead of the normal one $\mathrm{R}^{\prime \prime \prime}{ }_{4} \mathrm{Si}_{4} \mathrm{O}_{14}$, to which Mackintosh's results closely conform.

\section{DISCUSSION OF BENEDICKS'S FORMULA FOR THALENITE.}

Moreover, in the light of the data furnished by Benedicks himself it can not be admitted that the formula $\mathrm{H}_{2} \mathrm{Y}_{4} \mathrm{Si}_{4} \mathrm{O}_{15}$ for thalénite is established.

Water was determined by him according to Penfield's method, ${ }^{a}$ but without any hint as to the particular modification employed. If, as seems probable, the water expelled from the mineral was caused to recondense in the cooler part of the ignition tube, the latter being then weighed, and again after driving the condensed water out, two serious sources of error have to be considered: (1) The $\mathrm{CO}_{2}$ present in the mineral, which would count in part as water unless a very careful correction was made, as provided for by Penfield. No mention is made by Benedicks of any such correction. (2) Nitrogen and helium are said to comprise 1.4 per cent of the mineral by weight. If so, these would introduce an error in the above water determination of contrary sign to that due to $\mathrm{CO}_{2}$, and if the proportion of helium were large this error might be of very considerable magnitude.

In an appendix to his paper. Benedicks gives an analysis of what he considers to be a very pure form of thalénite. He makes no comparison of this with his earlier analysis, nor does he deduce a molecular ratio, which I find to be $1: 2.6: 5.15$, or $1: 3.03: 6.02$ if small amounts of lime, magnesia, and soda are neglected, instead of $1: 2: 4$, as required by his formula. There being no $\mathrm{CO}_{2}$ in this purer material, the value for water (if determined as above surmised) may be supposed to bc affected only by the error due to nitrogen and helium. It will be seen that the neglect to regard lime, magnesia, and soda in his second analysis affects the ratio very seriously. .This neglect may be justified in figuring on his first analysis because of an approximate balancing by $\mathrm{CO}_{2}$, but it would be by no means so in the other, in spite of the very satisfactory ratio obtained and leading to the empirical formula 
$\mathrm{R}^{\prime \prime} \mathrm{R}^{\prime \prime \prime}{ }_{6} \mathrm{Si}_{6} \mathrm{O}_{22}$, which is susceptible of a variety of interpretations. It may represent a basic salt of diorthosilicic acid $\mathrm{R}^{\prime \prime} \mathrm{R}^{\prime \prime \prime}{ }_{5}\left(\mathrm{R}^{\prime \prime \prime} \mathrm{O}\right)^{\prime}\left(\mathrm{Si}_{2} \mathrm{O}_{7}\right)_{3}$ or of metasilicic acid $\mathrm{R}^{\prime \prime} \mathrm{R}^{\prime \prime \prime}{ }_{2}\left(\mathrm{R}^{\prime \prime \prime} \mathrm{O}\right)^{\prime}{ }_{4}\left(\mathrm{SiO}_{3}\right)_{6}$, or possibly even of other acids.

Finally, if the values for nitrogen and helium are really anywhere near so great as given, an additional argument against the validity of his formula is furnished. For in the light of Kohlschütter's recent researches ${ }^{a}$ and my own less conclusive work of a much earlier date, ${ }^{b}$ it is in the highest degree probable that nitrogen and helium are not occluded in uraninite and other minerals, but are in chemical combination. Now, if this is so, in a mineral containing as much as 1.4 per cent of nitrogen by weight, this must, quite irrespective of its form of combination, play so important a rôle in the molecule as to utterly invalidate any formula based on calculations from which it is omitted. If the above percentage is made up in large part of helium, its effect, because of its low atomic weight, must be vastly greater than that of nitrogen.

Until light is thrown on the nature of the combinations these two gases form in minerals, no very positive conclusions can be reached as - to the formulas to be assigned to those minerals which contain them in more than traces.

\section{CHEMICAL INVESTIGATION OF YT'PRIALITE.}

At the earnest request of Mr. W. E. Hidden, the discoverer of yttrialite, I undertook to reanalyze the mineral in order if possible to settle definitely the question of its composition. This seemed especially desirable since a large quantity of very fine material was available.

The appearance and behavior of the mineral agreed in all respects except one with those of the original description. ${ }^{c}$ It is there stated that the strongly ignited mineral is insoluble in acid. This is a mistake, for when powdered its solubility in hydrochloric acid is even then perfect, although not rapid.

Careful examination of thin sections under the microscope showed a condition that augured ill for decisive analytical results despite the apparently fine quality of the large specimens. Distinctly foreign mineral fragments were as good as absent except for insignificant coatings of a white alteration product, presumably a carbonate; but considerable shading was apparent in the slides, indicative of alteration or intimate contamination in the mass of the mineral itself. However, after treatment with hot dilute hydrochloric acid (wherehy much yttritlite was dissolved) followed by dilute sodium carbonate, the

a Ann. der Chem., 317, 1901, p. 158.

b Bull. U. S. Geol..Survey No. 78, 1891, pp. 76-78.

cAm. Jour. Sci., ser. 3, vol, 38, 18899, p. 477. 
clear glassy residue appeared to be improved in appearance and the specific gravity of two samples, each composed of small grains uniform in size for each sample, had risen from 4.596 and 4.590 to 4.654 at $232^{\circ} \mathrm{C}$. and 4.646 at $26^{\circ} \mathrm{C}$., respectively. The two sizes were then mixed, giving one sample of about $4.65 \mathrm{sp}$. gr. at $25^{\circ} \mathrm{C}$. That of the unpurified material analyzed by Mackintosh was 4.575.

Qualitative tests showed the absence of zirconium, glucinum, and aluminum and the presence of a little more than a trace of fluorine, of a very little carbon dioxide, besides some other gases which were set free by treatment with acids and by fusion with an alkali carbonate.

Silica was separated by two evaporations with hydrochloric acid; lead was then thrown out by hydrogen sulphide.

The earths when finally collected together free from all iron, manganese, uranium, titanium, phosphorus, calcium, and magnesium, were ignited and weighed. No filtrate from a precipitate of earth oxalates was ever regarded as free from earths till after evaporating, igniting, and retesting. This is a needed precaution in all similar analyses.

The combined earths were dissolved in nitric acid and evaporated to dryness. A,saturated solution of potassium sulphate was poured upon the dry mass, which wholly dissolved but almost at once began to deposit double sulphates. Solid potassium sulphate was then added in crystals. After twenty-four hours the precipitate was collected on a filter and washed with the precipitant solution. Twice was this precipitation repeated after first dissolving the double salts in acid, precipitating by potassium hydroxide, washing, redissolving in nitric acid, and evaporating. Then only was the extraction of the yttriumerbium group practically complete. From the combined filtrates the soluble earths were thrown out, reconverted into nitrates, and again treated with potassium sulphate, whereby a little further insoluble matter was obtained. Yttrium-erbium oxides obtained from the oxalates gave a light-colored mixture of $265.6 \mathrm{Mol}$. W. (108.8 At. W.), which furnished a pink nitrate solution showing the erbium absorption bands strongly marked, with very faint indications of the strongest band of the didymium components.

The insoluble sulphates were converted into chlorides and thrice treated with potassium hydroxide and chlorine to precipitate thorium and cerium. From the filtrates the soluble earths were recovered and subjected to a repetition of this treatment. Their oxides after purification were light dirty brown when heated over the Bunsen flame, but grayish white when blasted. Their Mol. W. was 335.5 (At. W. 143.7); their nitrate solution was pink and gave the characteristic didymium component absorption bands altogether free from those of the erbium. constituents. 
Cerium and thorium were separated by a combination of the ammonium oxalate and thiosulphate methods. The weighed thoria was pure white, the ceria of a pale salmon color.

The condition of the uranium was shown by its precipitability as tetrafluoride on dissolving the mineral in hydrofluoric acid. This reaction afforded a ready means of estimating with exactness the ferrous iron by permanganate after rapidly filtering off the fluorides precipitated in an atmosphere of carbon dioxide. Solution of the mineral in a sealed tube with dilute sulphuric acid allowed of finding the oxygen value of both $\mathrm{UO}_{2}$ and $\mathrm{FeO}$ by permanganate. The result thus found for $\mathrm{UO}_{2}$ agreed marvelously well with that calculated from the $\mathrm{U}_{3} \mathrm{O}_{8}$ found gravimetrically in a separate portion.

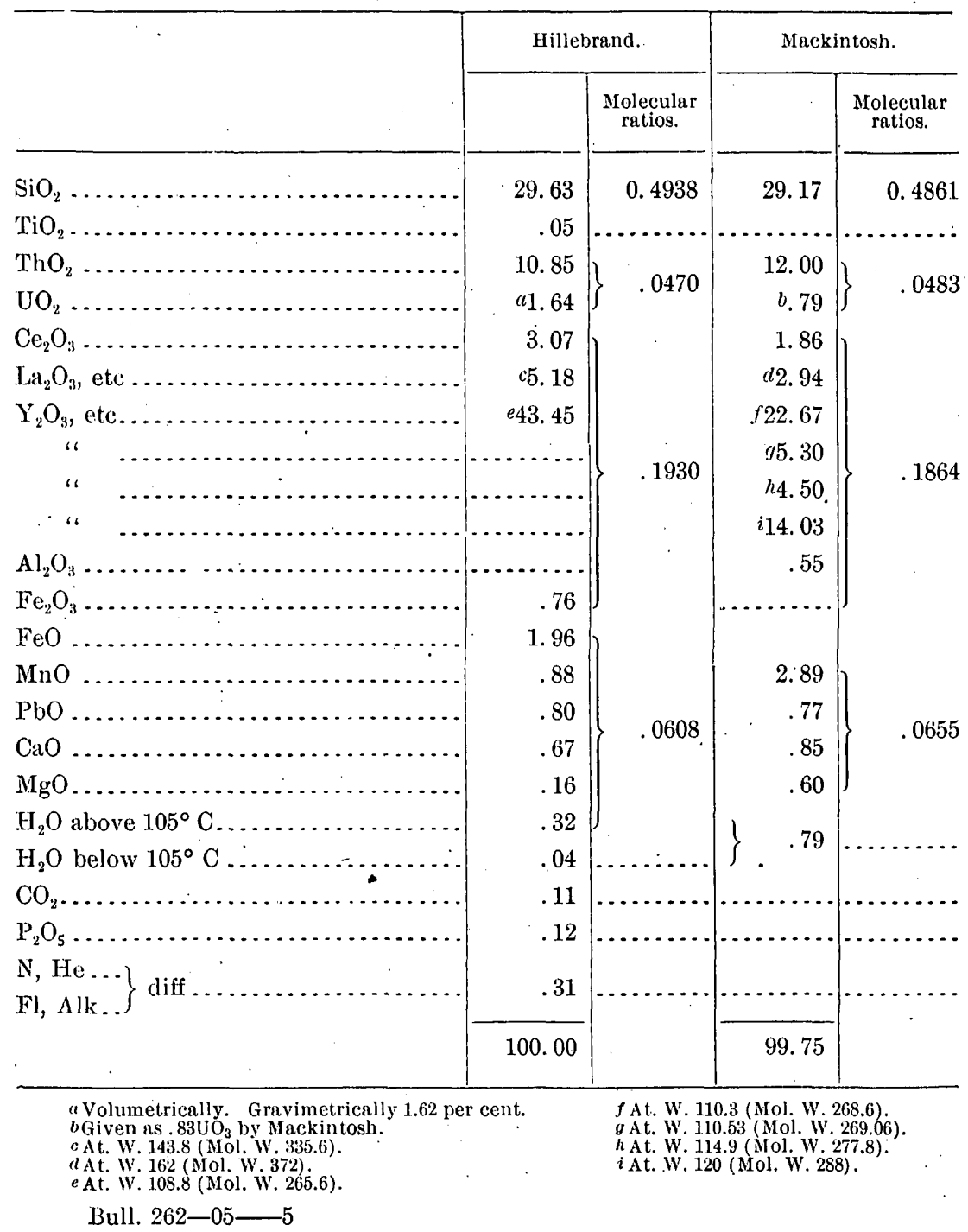


Nitrogen (?) and helium (?) were obtained quantitatively by fusing the mineral with sodium-potassium carbonate in a current of carbon dioxide and collecting the gases in a nitrometer over potassium hydroxide. The volume was between one and two cubic centimeters per gram of yttrialite. The gases were not further examined.

The analysis is.given above, together with that of Mackintosh for: comparison.

The ratios of Mackintosh's analysis as calculated above by me are certainly wrong in so far as they are affected by the value for iron, which he assumed to be wholly ferrous. If corrected in accordance with the statement of my analysis, or, what amounts to the same thing for the purpose of illustration and is simpler, if my ratio is altered to conform to his statement for $\mathrm{RO}$ and $\mathrm{R}_{2} \mathrm{O}_{3}$ bases, it becomes .0644: .1882-a very close agreement.

It is altogether probable that Mackintosh's separations of the earths were not so far reaching as mine, and this belief is borne out by the differences in the experimental molecular weights for the lanthanum and yttrium groups, mine being more in accordance with what might be expected and, moreover, agreeing almost exactly with those which were found by me for rowlandite in 1893, namely, 336.8 and 266.2 respectively. ${ }^{a}$

It is of course impossible to say what disposition should be made of the small amounts of firmly held water, phosphorus, carbon dioxide, fluorine, and alkalies. The ratios of my analysis are', therefore, to a slight extent incorrect, but probably not enough to influence any conclusions that may be drawn. One thing is apparent, that the preliminary purification by acid has had no pronounced effect on the composition of the mass acted on, otherwise Mackintosh's and my analyses should show far greater differences in the main constituents.

The crude empirical formulas deducible from the ratios of the two analyses are nearly

$$
\begin{array}{lllll}
\text { Hillebrand } \ldots \ldots \ldots \ldots & \mathrm{R}^{\prime \prime}{ }_{61} & \mathrm{R}^{\prime \prime \prime}{ }_{386} & \mathrm{R}^{\prime \prime \prime \prime}{ }_{47} & \left(\mathrm{Si}_{2} \mathrm{O}_{7}\right)_{247} \\
\text { Mackintosh … } \ldots \ldots \ldots \ldots & \mathrm{R}^{\prime \prime}{ }_{65} & \mathrm{R}^{\prime \prime \prime}{ }_{373} & \mathrm{R}^{\prime \prime \prime \prime}{ }_{48} & \left(\mathrm{Si}_{2} \mathrm{O}_{7}\right)_{243}
\end{array}
$$

a The three minerals gadolinite, yttrialite, and rowlandite occur in Llano County in most in timate association, suggestive of close community of origin, a suggestion which is emphasized by the marvelous agreement for gadolinite and yttrialite, not only in the relative proportions of the trivalent

\begin{tabular}{|c|c|c|c|}
\hline & $\mathrm{Ce}_{2} \mathrm{O}_{3}$ & $\mathrm{La}_{2} \mathrm{O}_{3}$, etc. & $\mathrm{Y}_{2} \mathrm{O}_{3}$, etc. \\
\hline Gadolinite (Genth) ........ & 2.65 & 5.22 & 44.35 \\
\hline Do.......................... & 2.66 & 5.01 & 4.45 \\
\hline Gadolinite (Eakins) ..................... & 2.62 & 5.22 & 41.55 \\
\hline Yttrialite (Hillebrand) .................... & 3.07 & 5.18 & 43.45 \\
\hline Rowlandite (Hillebrand) $\ldots \ldots \ldots \ldots \ldots \ldots \ldots \ldots \ldots$ & 5.06 & 9.34 & 47.70 \\
\hline
\end{tabular}
earth metals but in their absolute amounts as well.

This concordant testimony of three annlysts may be regarded as strong evidence of the correctness of the earth separations made by them in these cases. Nearly the same relation is showu by the trivalent earth-metals of rowlandite, as seen in the table above. 
there being a slight deficiency of oxygen atoms in each case for the radical $\mathrm{Si}_{2} \mathrm{O}_{7}$, which is increased by allowing for the $\mathrm{CO}_{2}$ and $\mathrm{P}_{2} \mathrm{O}_{5}$.

In so far then as the character of the acid radical is concerned the results of Mackintosh's analysis are fully confirmed, and there is absolutely no ground for accepting Benedicks's basic formula, which, as I have already shown (p. 62), is based on a palpable error. But the ratios are not at all such as to lend themselves to ready resolution into isomorphous salts of the acid $\mathrm{H}_{6} \mathrm{Si}_{2} \mathrm{O}_{7}$. By doing quite unwarranted violence to the analytical data the above formulas might be reduced to

$$
\mathrm{R}^{\prime \prime} \quad \mathrm{R}_{6}^{\prime \prime \prime} \mathrm{R}^{\prime \prime \prime \prime} \quad\left(\mathrm{Si}_{2} \mathrm{O}_{7}\right)_{4}
$$

which can be readily represented structurally as a single complex moleoule or as a mixture of molecules like $3 \mathrm{R}^{\prime \prime \prime}{ }_{2} \mathrm{Si}_{2} \mathrm{O}_{7}+\mathrm{R}^{\prime \prime} \mathrm{R}^{\prime \prime \prime} \mathrm{Si}_{2} \mathrm{O}_{7}$. In neither case, however, is the type of the rowlandite molecule approached, which requires an altogether different ratio of monoxide, dioxide, and trioxide bases; nor, if the second be accepted, is it at all clear that the two molecules would be mineralogically equivalentthat is, isomorphous.

An alternative hypothesis is to regard the mineral as a mixture containing the anhydrous thorite molecule. Proceeding on this assumption and deducting all thorium and uranium and the proper amounts of silicon and oxygen, the crude empirical formulas become

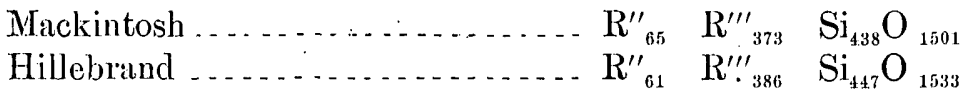

which may be interpreted as basic salts of metasilicic acid:

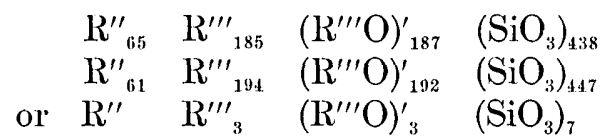

this last being easily susceptible of symmetrical representation in graphic form.

On the whole, I prefer to leave the constitution of yttrialite unsettled until further evidence can be gathered, either from analyses of allied minerals or from yttrialite itself of more certain purity than any that has yet been discovered.

It must not be forgotten that the gases other than $\mathrm{CO}_{2}$ contained in the mineral may be the cause of the inability to arrive at satisfactory conclusions in the case of this and all other minerals which contain them, as I have already pointed out on page 63 .

My excuse for such a lengthy publication on a matter still unsettled is the desire to prevent general acquiescence in the grouping under one type of minerals which can by no means be regarded as proved to belong to that type, and to which yttrialite certainly does not belong. 


\section{SUMMARY.}

The empirical formula of Hidden and Mackintosh for yttrialite is confirmed, and it is shown that the basic formula of Benedicks rests on error and has no standing.

The formula of Hidden and Mackintosh is not, however, susceptible of representation as a simple salt of the acid $\mathrm{H}_{6} \mathrm{Si}_{2} \mathrm{O}_{7}$. On the purely hy pothetical assumption of admixture of anhydrous thorite, the remaining constituents afford ratios conforming quite closely to those of a basic metasilicate $\mathrm{R}^{\prime \prime} \mathrm{R}^{\prime \prime \prime}{ }_{3}\left(\mathrm{R}^{\prime \prime \prime} \mathrm{O}\right)_{3}^{\prime}\left(\mathrm{SiO}_{3}\right)_{7}$.

It is shown for two reasons fully discussed that the formula proposed by Benedicks for thalénite is to be regarded as doubtful. 


\title{
A PSEUDO-SERPEN'IINE FROM STEVENS COUN'TY, WASHING'ION,
}

\author{
By F. W. Clatke.
}

In the course of an investigation upon the ornamental stones of Stevens County, Wash., Mr. R. W. Thatcher and Prof. Elton Fulmer, of the State Agricultural Experiment Station, examined a supposed serpentine which proved to have quite anomalous composition. To the unaided eye the rock was ordinary serpentine of a typical yellowish green color; it was fairly homogeneous, and capable of receiving a fine polish. Incomplete analyses, however, by both of the above-named chemists showed that it was not serpentine, and as I had been consulted with regard to the interpretation of the data; a sample was sent to me for more exhaustive study.

According to Prof. S. Shedd of the Washington Agricultural College, who is conducting the investigation, the rock is from the quarry of the United States. Marble Company, 12 miles north and west from Valley, a station on the Spokane Falls and Northern Railroad. It outcrops on the face of a high bluff at an elevation of about 4,070 feet above sea level, and forms a wedge-shaped mass cutting across the mountains in a direction $5^{\circ}$ west of north. The adjacent rocks are slates, which lie conformably upon a very coarsely crystalline, dark, almost black, magnesian carbonate. The "serpentine" itself varies a good deal in color, and a series of samples in the United States National Museum show that the output of the locality is far from uniform. They range from a white carbonate, through various intermediate mixtures of the verde antique type, to material which appears to be ordinary serpentine. The latter, however, as shown by the serpentine under consideration, is distinctly laminated in structure, and exhibits a splintery fracture. An analysis by Mr. George Steiger gave the following results:

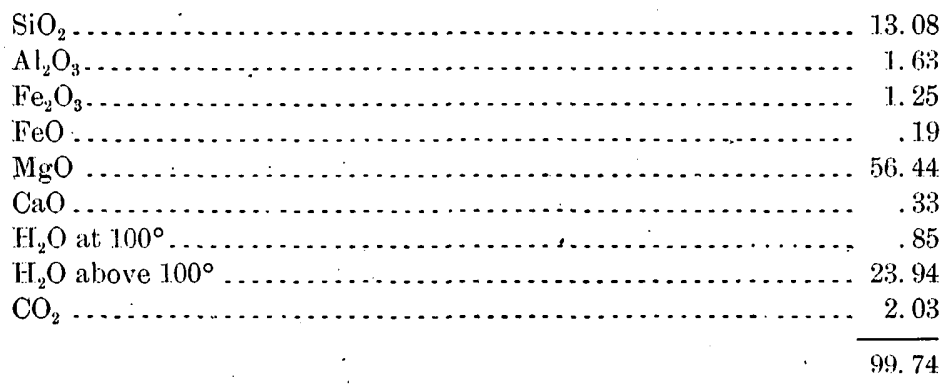


These figures at once suggest a probable admixture of brucite with the serpentinous material, and a microscopic examination by Mr. J. S. Diller tends to confirm this supposition.

According to $\mathrm{Mr}$. Diller the specimen is mainly composed of three minerals, $a, b$, and $c$. The first two have nearly equal indices of refraction, but differ widely in birefringence. The mineral $a$ is the most abundant. In transmitted light it is colorless, but between crossed nicols it exhibits brilliant colors. The mineral $b$ is pale green, and intermingled with $a$. Its birefringence yields weak colors, quite characteristic of chlorite. In quantity it is less than one-fourth of $a$.

Mineral $e$ is granular, in scattered grains and irregular groups with a high index of refraction and a birefringence which suggests a carbonate, but it does not effervesce with a dilute acid. It amounts to not more than 5 per cent of the whole. Mineral $b$ is certainly chlorite, and $a$ may be brucite or possibly serpentine.

By applying Mr. Diller's observations to the analysis of the rock, the proximate composition of the latter may be deduced; although certain assumptions must be made. The carbonate present is probably hydromagnesite, for that species is a frequent associate of brucite. The composition of the chlorite is unknown, but it may be interpreted as essentially clinochlore, and as proportional to the ferric oxide and alumina. So much assumed, the analysis gives the following approximate results expressing the composition of the specimen:

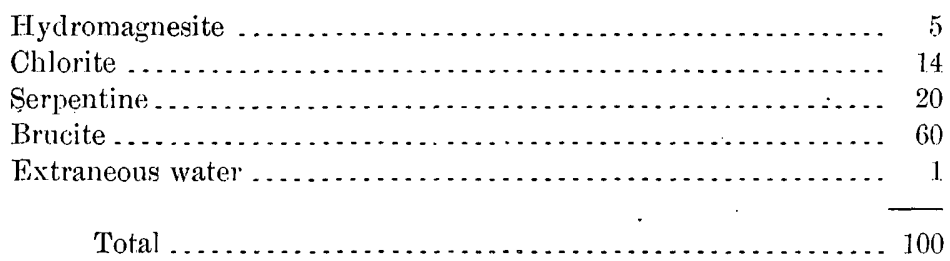

In this, four minerals appear instead of three, but the microscopic examination did not attempt to discriminate between the brucite and the serpentine.

In order to obtain evidence confirmatory of the foregoing conclusions, a few experiments were made, tending toward fractional determinations. Upon digesting the powdered rock for two hours with cold, dilute nitric acid (10 per cent by volume), 1.32 per cent of $\mathrm{Fe}_{2} \mathrm{O}_{3}+\mathrm{Al}_{2} \mathrm{O}_{3}$ and 47.29 per cent $\mathrm{MgO}$ went into solution. In a similar experiment with cold, 20 per cent acetic acid, $0.69 \mathrm{Fe}_{2} \mathrm{O}_{3}+\mathrm{Al}_{2} \mathrm{O}_{3}$ and 45.64 $\mathrm{MgO}$ were extracted. Brucite dissolves readily in acids of the indicated strength, but some chlorite was evidently attacked as well. I also found that ordinary serpentine was quite appreciably acted upon by weak acetic acid. These experiments, then, merely show that the rock contains a large amount of magnesium in a very easily soluble 
condition, the quantity equivalent to 60 per cent of brucite being 41.4 . The results are in harmony with the conclusions already reached, and belp to support them, although accurate fractional determinations can not be made. The rock is unusual in character, and if the sample examined is fairly characteristic of the entire deposit, the latter should be carefully studied in reference to its origin and its geological relations. 


\section{ON "CALIFORNITE."}

By F. W. Clarke and George Steiger.

In $1901 \mathrm{Mr}$. G. F. Kunz ${ }^{a}$ called attention to a remarkable massive variety of vesuvianite, discovered in California by Mr. A. E. Heighway, and which at first was thought to be jade. A second locality for the mineral, remote from the first, was found some time later, and here the vesuvianite was accompanied by another substance, which proved upon examination to be an unusual modification of garnet. For the vesuvianite Mr. Kunz proposed the varietal name "californite," and at first the garnet was supposed to be the same species, but different in color. Samples of all three minerals were sent to the laboratory of the United States Geological Survey for analysis, and the results obtained are given below. ${ }^{b}$

A. Vesuvianite from the south fork of Indian Creek, 12 miles from Happy Camp, Siskiyou County, Cal.

B. Vesuvianite from Fresno County, Cal., 35 miles east of Selma.

C. White garnet, found with or near vesuvianite B.

\begin{tabular}{|c|c|c|c|}
\hline . & $\begin{array}{l}\text { A. Vesuivi } \\
\text { anite. }\end{array}$ & $\begin{array}{l}\text { B. Vesuvi- } \\
\text { anite. }\end{array}$ & C. Garnet. \\
\hline $\mathrm{SiO}_{2} \ldots$ & 35.86 & 36.55 & 38.59 \\
\hline $\mathrm{Al}_{2} \mathrm{O}_{3} \ldots$ & 18.35 & 18.89 & 22.24 \\
\hline $\mathrm{Fe}_{2} \mathrm{O}_{3} \ldots \ldots \ldots \ldots \ldots \ldots$ & 1.67. & .74 & .45 \\
\hline $\mathrm{FeO} \ldots \ldots \ldots \ldots$ & .39 & .74 & .36 \\
\hline $\mathrm{MnO} \ldots \ldots \ldots \ldots \ldots \ldots \ldots$ & .05 & none & .10 \\
\hline $\mathrm{MgO} \ldots . .$. & 5.43 & 2.33 & .64 \\
\hline $\mathrm{CaO} \ldots \ldots$. & 33.51 & 35.97 & 35.97 \\
\hline $\mathrm{H}_{2} \mathrm{O}$ at $105^{\circ} \ldots$. & .29 & .58 & .31 \\
\hline $\mathrm{H}_{2} \mathrm{O}$ above $105^{\circ}$. & 4. 18 & 3.42 & .80 \\
\hline $\mathrm{TiO}_{2}: \ldots \ldots \ldots \ldots \ldots \ldots \ldots \ldots$ & .10 & none & none \\
\hline $\mathrm{CO}_{2} \ldots \ldots \ldots \ldots \ldots$ & -..... & .91 & .39 \\
\hline $\mathrm{P}_{2} \mathrm{O}_{5} \ldots \ldots \ldots$ & .02 & $\ldots .$. & ….. \\
\hline \multirow[t]{2}{*}{$\mathrm{F} \ldots \ldots \ldots \ldots \ldots \ldots \ldots \ldots$} & none & .13 & .17 \\
\hline & 99.85 & 100.26 & 100.02 \\
\hline \multirow[t]{2}{*}{ Less $\mathrm{O}=\mathrm{F} \ldots \ldots \ldots \ldots \ldots \ldots \ldots \ldots \ldots \ldots \ldots \ldots \ldots \ldots$} & .......... & .05 & .07 \\
\hline & & 100. 21 & 99.95 \\
\hline Specific gravity ... & & 3. 359 & 3.586 \\
\hline
\end{tabular}

a Mineral Resources U. S. for 1901, U. S. Geol. Survey; 1902, p. 747. Also, more fully, Am. Jour. Sci., 1th ser., vol. 16, 1903, p. 397.

$b$ Analyses by George Steiger. 
These analyses may be reduced to uniform type as follows: Throw out hygroscopic water, $\mathrm{P}_{2} \mathrm{O}_{5}$, and $\mathrm{CO}_{2}$, with the equivalent amount of lime representing calcite. Recalculate $\mathrm{TiO}_{2}$ to equivalent $\mathrm{SiO}_{2} ; \mathrm{Fe}_{2} \mathrm{O}_{3}$ to $\mathrm{Al}_{2} \mathrm{O}_{3} ; \mathrm{FeO}, \mathrm{MnO}$, and $\mathrm{MgO}$ to $\mathrm{CaO}$, and $\mathrm{F}$ to $\mathrm{H}_{2} \mathrm{O}$. Then recompute to 100 per cent. The reduced analyses are as follows:

\begin{tabular}{|c|c|c|c|c|c|c|}
\hline & \multicolumn{3}{|c|}{ Analyses. } & \multicolumn{3}{|c|}{ Molecular ratios. } \\
\hline & A. & B. & C. & A. & B. & $\mathrm{C}$. \\
\hline $\mathrm{SiO}_{2}, \ldots \ldots \ldots \ldots \ldots \ldots$ & 35.58 & 37.28 & 39.09 & 0.589 & 0.617 & .0 .647 \\
\hline $\mathrm{Al}_{2} \mathrm{O}_{3} \ldots \ldots \ldots \ldots$ & 19.24 & 19.74 & 22.82 & .188 & .193 & .223 \\
\hline $\mathrm{CaO} \ldots \ldots \ldots$. & 41.03 & 39.42 & 37.22 & .731 & .703 & .664 \\
\hline \multirow{2}{*}{$\mathrm{H}_{2} \mathrm{O}$} & 4.15 & 3.56 & .87 & .231 & .197 & .048 \\
\hline & 100.00 & 100: 00 & 100.00 & & & \\
\hline
\end{tabular}

Analysis C gives the garnet ratios quite sharply, but as the mineral was white and massive, somewhat resembling chalcedony, its nature was at first unsuspected. Its density is that of garnet, however, its fusibility is the same, and in thin section under the microscope it is optically isotropic. It is undoubtedly garnet containing as an impurity about 1 per cent of calcium carbonate.

Analyses $\mathrm{A}$ and $\mathrm{B}$ are less easily interpreted. Bives approximately the empirical formula: $2 \mathrm{H}_{2} \mathrm{O}, 2 \mathrm{Al}_{2} \mathrm{O}_{3}, 7 \mathrm{CaO}, 6 \mathrm{SiO}_{2}$; or, constitutionally,

$$
\mathrm{Al}_{2} \mathrm{Ca}_{7}\left(\mathrm{SiO}_{4}\right)_{6}(\mathrm{AlOH})\left(\mathrm{AlO}_{2} \mathrm{H}_{2}\right) \mathrm{H} \text {. }
$$

If part of the water is extraneous, the following much simpler formula may hold:

$$
\mathrm{Al}_{2} \mathrm{Ca}_{7}\left(\mathrm{SiO}_{4}\right)_{6}(\mathrm{AlOH})_{2} ;
$$

and this fairly represents a good many other analyses of vesurianite, but not all. Vesuvianite varies in composition, and its variations are rather troublesome to interpret, for they may signify either actual differences in the mineral itself, alterations, or impurities. The formula proposed by one of us ${ }^{a}$ some years ago,

$$
\mathrm{Al}_{2} \mathrm{Ca}_{6}\left(\mathrm{SiO}_{4}\right)_{5}(\mathrm{AlOH}) \text {, }
$$

is a good expression for the average composition of the species, but it does not fit the extremes. 
A careful study of over 40 analyses of vesuvianite leads us to suspect that it may be a mixture of several similar molecules, which we can represent by the subjoined expressions:

$$
\begin{aligned}
& \mathrm{Al}_{2} \mathrm{Ca}_{7}\left(\mathrm{SiO}_{4}\right)_{6}(\mathrm{AlOH})_{2}, \\
& \mathrm{Al}_{2} \mathrm{Ca}_{7}\left(\mathrm{SiO}_{4}\right)_{6}\left(\mathrm{AlO}_{2} \mathrm{H}_{2}\right)_{4}, \\
& \mathrm{Al}_{2} \mathrm{Ca}_{7}\left(\mathrm{SiO}_{4}\right)_{6} \mathrm{H}_{4}, \\
& \mathrm{Al}_{2} \mathrm{Ca}_{7}\left(\mathrm{SiO}_{4}\right)_{6} \mathrm{Ca}_{2} ;
\end{aligned}
$$

the first and third compounds usually predominating. Structurally, and with due regard to the analogy between vesuvianite and other species, these formule may be written as follows:
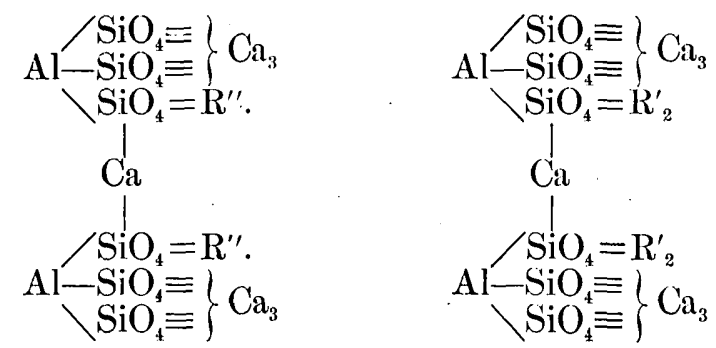

About one-seventh of the calcium is replaced by magnesium, and in the variety wiluite the group $\mathrm{BOH}$, analogous to $\mathrm{AlOH}$; probably occurs.

Vesuvianite, then, is to be regarded as a basic orthosilicate, belonging to a group of compounds of which garnet is the normal salt. Epidote and the scapolites are other members of the same class, and their formulæe are all strikingly similar to one another. As products of contact metamorphism they originate under like conditions, and they all undergo alteration in much the same way, yielding similar or even identical derivatives. Garnet, vesuvianite, epidote, and the scapolites must be considered together if the problem of their constitution is to be properly solved. 


\title{
T'HE ACTION OF SILVEER NIT'RATE AND THALLOUS NITRA'TE UPON CERT'TAIN NA'TURAL SILICATES.
}

\author{
By George Steiger.
}

The following investigation is practically a continuation of the experiments which were described by Clarke and Steiger in a recent bulletin of the United States Geological Survey, ${ }^{a}$ although the new work is along somewhat different lines.

In the former research the alkalies and alkaline earth metals of certain silicates were replaced by ammonium, when the minerals were heated in sealed tubes with ammonium chloride. In the present work, silver nitrate and thallous nitrate have been substituted for ammonium chloride, the temperature employed being somewhat above their fusing points. As was anticipated, the alkalies and alkaline earth metals were replaced by the heavy metal, thus giving additional data relative to the constitution of the minerals.

The experiments were carried out as follows: The very finely ground material was mixed thoroughly with various amounts of nitrate by grinding in an agate mortar, the mixture was placed in a tube of Jena glass, and the tube was sealed. These tubes were then heated in a bomb furnace for the specified time and temperature, then opened and the contents leached with boiling water till the filtrate gave no test for: nitrates. The residue was then dried and analyzed.

In a recent paper, ${ }^{b}$ the writer gave the results of some preliminary work on analcite and chabazite.

Heumann ${ }^{c}$ prepared a silver ultramarine by boiling the native mineral with a solution of silver nitrate, and A. H. Church ${ }^{d}$ made a silver phillipsite by allowing a solution of silver nitrate to act on the natural mineral at ordinary temperatures for almost three years.

For the optical notes in the present paper, the writer is indebted to Messirs. W. T. Schaller and J. S. Diller.

The crystals in all cases were too small to permit a determination of their forms. A few optical observations were made, and with the exception of the isotropic compounds, it can be said that all were entirely crystalline. 


\section{ANAT,CITE.}

The analcite upon which the following experiments were made was well crystallized material from Table Mountain, near Golden, Colo.

Three silver derivatives were prepared as follows:

A. Ammonium analcite was heated in a sealed tube with four times its weight of dry silver nitrate for 4 hours at $250^{\circ}-290^{\circ} \mathrm{C}$, then leached with boiling water and the residue dried on the water bath.

B. The natural analcite was heated in a sealed tube with four times its weight of dry silver nitrate for 4 hours at $250^{\circ}-290^{\circ} \mathrm{C}$., then leached and the residue dried on the water bath.

C. Same as B, but heated 6 instead of 4 hours.

D. Analysis of the analcite upon which the experiments were made. Analysis gave the results shown below:

\begin{tabular}{|c|c|c|c|c|}
\hline & A. & B. & c. & D. \\
\hline $\mathrm{SiO}_{2}$ & 42.69 & $41 . .31$ & 40.08 & .55 .72 \\
\hline $\mathrm{Al}_{2} \mathrm{O}_{3}$. & 18. 22 & 1.6. 44 & 16. 29 & 23.06 \\
\hline $\operatorname{Ag}_{2} \mathrm{O} \ldots$ & 32.01 & 37.45 & 36.91 & ...... \\
\hline $\mathrm{CaO} \ldots \ldots \ldots \ldots \ldots$ & $\cdots \cdots$ & $\cdots \cdots$ & - . . . . & .17 \\
\hline $\mathrm{Na}_{2} \mathrm{O} \quad \ldots \ldots \ldots \ldots \ldots \ldots$ & .68 & .85 & .81 & 12.46 \\
\hline $\mathrm{H}_{2} \mathrm{O}-\ldots \ldots \ldots \ldots \ldots \ldots \ldots \ldots \ldots \ldots \ldots$ & & $\ldots$. & & .13 \\
\hline $\mathrm{H}_{2} \mathrm{O}+\ldots \ldots \ldots \ldots \ldots \ldots \ldots \ldots \ldots$ & 6. 09 & 4. 29 & 5.86 & 8. 26 \\
\hline \multirow[t]{2}{*}{$\mathrm{NH}_{3}, \ldots \ldots \ldots \ldots \ldots \ldots \ldots \ldots$} & .69 & $\ldots \ldots \ldots$ & 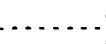 & $\ldots . . . .$. \\
\hline & 100.38 & 100.34 & 99.95 & 99. So \\
\hline \multicolumn{5}{|l|}{ In leach water: } \\
\hline $\mathrm{Na}_{2} \mathrm{O}, \ldots \ldots \ldots \ldots \ldots$ & .60 & 13.13 & 12.57 & $\therefore$ \\
\hline
\end{tabular}

The products were all perfectly white, showing that no free silver oxide contaminated the residue. Under the microscope a small amount of the material showed double refraction, but the larger portion of it was isotropic like the original mineral.

Residue A was hoiled for. 15 minutes with a 5 per cent solution of sodium carbonate, and only a trace of silica passed into solution. With nitric acid the silver analcite gives sandy silica, and does not gelatinize on evaporation.

A portion of residue $B$ was heated on the water bath for $2 \frac{1}{2}$ hours with a 10 per cent solution of sodium hyposulphite and afterwards washed with water. In the residue 9.45 per cent of $\mathrm{Na}_{2} \mathrm{O}$ was found, showing that the silver salt had been converted back into the sodium compound, though not completely, the theoretical amount of $\mathrm{Na}_{2} \mathrm{O}$ required being 14.1 per cent. Whether a hydrated salt bad been formed was not determined. After treatment in a similar manner with potassium cyanide 10.04 per cent of $\mathrm{K}_{2} \mathrm{O}$ was found in the residue. 
Considering the various amounts of alkali contained in the silver residues as unaltered analcite, deducting the equivalent amount and reducing the remainder to 100 , the above analyses give the results shown below: ${ }^{a}$

\begin{tabular}{|c|c|c|c|c|}
\hline 。 & $\Lambda$. & B. & C. & $\begin{array}{l}\text { Theoreticul } \\
\mathrm{Ag} \text { AI } \\
\mathrm{Si}_{2} \mathrm{O}_{6} \cdot \mathrm{H}_{2} \mathrm{O} \text {. }\end{array}$ \\
\hline $\mathrm{SiO}_{2} \ldots \ldots \ldots$ & 40.39 & 40.28 & 39.21 & 39.35 \\
\hline $\mathrm{Al}_{2} \mathrm{O}_{3}, \ldots \ldots \ldots \ldots$ & 17.27 & 15.92 & 15.90 & 16.72 \\
\hline $\operatorname{Ag}_{2} \mathrm{O} \quad \ldots \ldots \ldots \ldots \ldots$ & 36.65 & 39.78 & 39. 16 & 38.03 \\
\hline \multirow[t]{2}{*}{$\mathrm{H}_{2} \mathrm{O} \ldots \ldots \ldots \ldots \ldots$} & 5.69 & 4. 02 & 5.73 & 5.90 \\
\hline & 100.00 & 100.00 & 100.00 & 100.00 \\
\hline
\end{tabular}

For comparison, there is given in the last column the percentage composition of theoretical silver analcite. Residne B shows a deficiency of water, possibly owing to the use of too high a temperature in drying the powder before analysis. Residue $\mathrm{C}$ gives the following molecular ratios:

$$
26 \mathrm{Ag}_{2} \mathrm{O}, 24 \mathrm{Al}_{2} \mathrm{O}_{3}, 100 \mathrm{SiO}_{2}, 49 \mathrm{H}_{2} \mathrm{O} \text {, }
$$

agreeing well with the empirical formula

$$
\operatorname{AgAlSi} \mathrm{O}_{6} \cdot \mathrm{H}_{2} \mathrm{O} \text {. }
$$

Two thallium derivatives were prepared from the sime lot of analcite, as follows:

E. Natural analcite was heated in a sealed tube with four times its weight of thallous nitrate, twenty-four hours at $250^{\circ}-290^{\circ} \mathrm{C}$.

F. Same as E, except that the heating was continued for fortyeight hours. The composition of the two leached residues is given below.

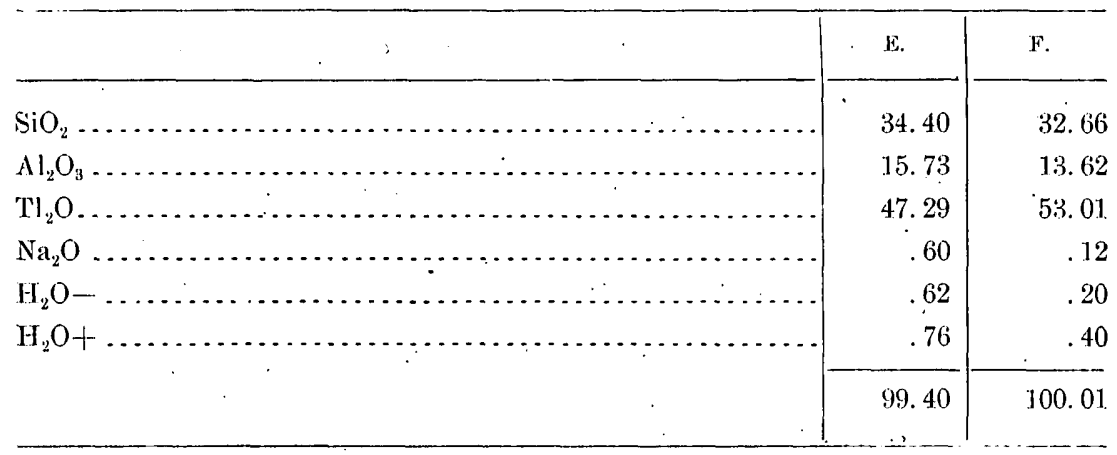

"In these and all other deductions made in this work the theoreticul molecule has been assumed, in this case, $\mathrm{NuAlSi}_{2} \mathrm{O}_{0} \mathrm{H}_{2} \mathrm{O}$. 
Both of the preparations were perfectly white. The microscopic examination showed thallium analcite to be mainly isotropic, with a few crystals having double refraction, as was the case with the silver derivative. The thallium compound is easily decomposed by nitric acid, giving sandy silica.

Deducting from analysis $\mathrm{F}$ analcite equivalent to 0.12 per cent of $\mathrm{Na}_{2} \mathrm{O}$, and reducing to 100 , the analysis becomes:

\begin{tabular}{|c|c|c|}
\hline . & Residue F. & $\begin{array}{l}\text { Theoreticul } \\
\text { TlAlsi } \mathrm{O}_{\mathrm{G}} \text {. }\end{array}$ \\
\hline $\mathrm{SiO}_{2} \ldots \ldots \ldots \ldots \ldots$ & 32.61 & 31.33 \\
\hline 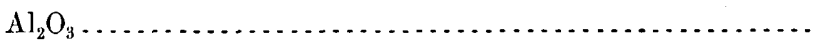 & 13.60 & 13.32 \\
\hline \multirow{2}{*}{ 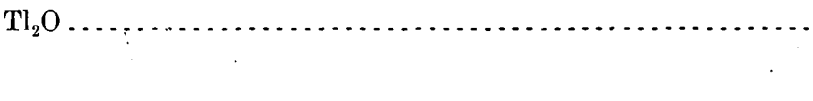 } & $5: 79$ & 55.35 \\
\hline & 100.00 & 100.00 \\
\hline
\end{tabular}

In the second column is given the calculated percentage composition of normal thallium analcite.

The molecular ratios of $\mathrm{F}$ are

$$
24 \mathrm{Tl}_{2} \mathrm{O}, 23 \mathrm{Al}_{2} \mathrm{O}_{3}, 100 \mathrm{SiO}_{2} \text {. }
$$

A closer agreement with theory could hardly be expected.

In the case of the silver compound, the one molecule of water of the original mineral has been retained, and it is essentially analcite with silver replacing sodium. It is not so with the thallium derivative, nor with the ammonium compound of the former investigation. In both of these derivatives the water of the original mineral was lost, the formula being that of leucite with thallium or ammonium replacing potassium, leucite being a mineral closely related to analcite.

One crude experiment was made to show the action of lead nitrate on this mineral. Natural analcite was heated in a sealed tube with a 10 per cent solution of lead nitrate for six hours at about $200^{\circ} \mathrm{C}$. The composition of the washed and dried residue follows:

\begin{tabular}{|c|c|c|}
\hline . & & $\begin{array}{l}\text { Molecular } \\
\text { ratios. }\end{array}$ \\
\hline $\mathrm{SiO}_{2} \ldots \ldots \ldots \ldots$ & 60.34 & 100.0 \\
\hline $\mathrm{Al}_{2} \mathrm{O}_{3}$ & 17.55 & 17.1 \\
\hline 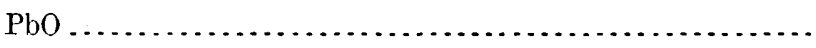 & 14. 75 & 6.1 \\
\hline $\mathrm{Na}_{2} \mathrm{O}$ & 6.03 & 9.7 \\
\hline \multirow[t]{2}{*}{$\mathrm{H}_{2} \mathrm{O}$} & undet. & $\ldots . . . . .$. \\
\hline & 98.67 & \\
\hline
\end{tabular}


Water was not determined, but, as will be seen from the summation, it is an unimportant constituent of the compound. Evidently the anhydrous salt has been formed, but incompletely, for only about half the sodium had been replaced.

The molecular ratios are as follows:

$$
6 \mathrm{PbO}, 10 \mathrm{Na}_{2} \mathrm{O}, 17 \mathrm{Al}_{2} \mathrm{O}_{3}, 100 \mathrm{SiO}_{2},
$$

or, combining the monoxide bases,

$$
16 \mathrm{RO}, 17 \mathrm{Al}_{2} \mathrm{O}_{3}, 100 \mathrm{SiO}_{2} \text {. }
$$

In this a large excess of silica appears.

\section{THUCITE.}

The specimen of leucite at hand was impure, and more careful work was therefore deferred until some future time, when it may be possible to prepare an artificial mineral which will be studied in detail.

One preparation of the impure leucite was made by heating the native mineral in a sealed tube with four times its weight of thallous nitrate for twenty-four hours at a temperature of $250^{\circ}-290^{\circ} \mathrm{C}$. The leached residue was dried on the water bath. The analysis of this

\begin{tabular}{|c|c|c|}
\hline . & Residue. & $\begin{array}{l}\text { Molecular } \\
\text { rutios. }\end{array}$ \\
\hline $\mathrm{SiO}_{2} \ldots \ldots \ldots \ldots \ldots \ldots \ldots \ldots \ldots$ & 36.00 & 100.0 \\
\hline $\mathrm{Al}_{2} \mathrm{O}_{3}, \ldots \ldots \ldots \ldots \ldots \ldots \ldots \ldots \ldots \ldots$ & 16.32 & 26.7 \\
\hline 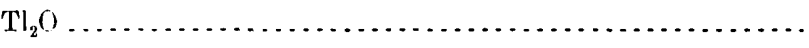 & 42.77 & 16.8 \\
\hline 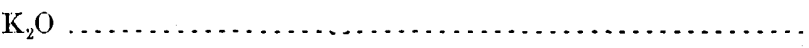 & 4. 26 & 7.5 \\
\hline 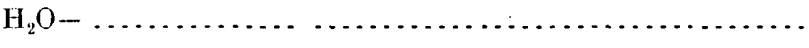 & .10 & \\
\hline \multirow[t]{2}{*}{ 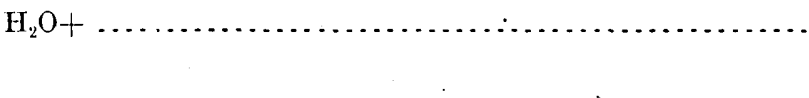 } & .20 & 1.5 \\
\hline & 99.65 & \\
\hline
\end{tabular}
residue follows.

Combining potassium with thallium, the analysis gives the following:

$$
24(\mathrm{TIK})_{2} \mathrm{O}, 27 \mathrm{Al}_{2} \mathrm{O}_{3}, 100 \mathrm{SiO}_{2}, 2 \mathrm{H}_{2} \mathrm{O} \text {. }
$$

This indicates that the same molecule has been formed as in the case of analcite.

\section{THOMSONITE.}

The thomsonite used was well crystallized material from Table Mountain, Colorado. Only one derivative of this mineral was made. The thomsonite was heated in a sealed tube with four times its weight of dry silver nitrate, 20 hours, at $250^{\circ}-290^{\circ} \mathrm{C}$. The residue was dried at about $40^{\circ} \mathrm{C}$. Its composition is given on the page following. 


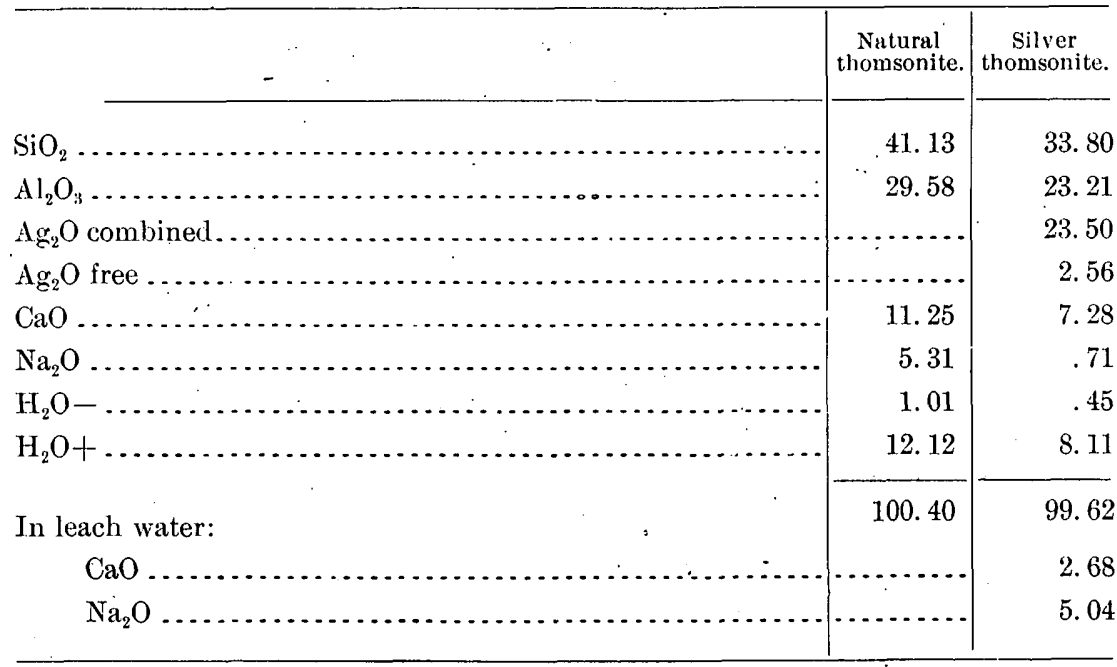

The color of this residue was dark, showing that some silver oxide had been formed, so contaminating the salt. A determination of this free silver oxide was made by the following method, and it appears in the analysis as " $\mathrm{Ag}_{2} \mathrm{O}$ free."

A portion of the silver thomsonite was weighed out in a platinum boat and placed in a glass tube, which was connected with a weighed calcium chloride tube; low red heat was then applied and at the same time a current of dry air was passed over it. At this temperature silver oxide is decomposed, liberating the entire amount of oxygen. The loss of weight in the boat was water plus oxygen, the gain in the tube was water alone; the difference represented the oxygen of the free silver oxide.

The new compound dissolves easily in dilute nitric acid to a clear solution, which forms a perfect jelly on evaporation. Under the microscope the material proved to be entirely crystalline, showing parallel extinction.

Deducting free silver oxide, and also the water lost below $100^{\circ}$, and reducing to 100 per cent, the analysis gives the results tabulated below:

\begin{tabular}{|c|c|c|}
\hline . & $\begin{array}{c}\text { Silver thom- } \\
\text { sonite re- } \\
\text { duced. }\end{array}$ & $\begin{array}{l}\text { Molecular } \\
\text { ratios. }\end{array}$ \\
\hline $\mathrm{SiO}_{2} \ldots \ldots \ldots \ldots \ldots \ldots \ldots$ & 34.99 & 100.0 \\
\hline $\mathrm{Al}_{2} \mathrm{O}_{3} \ldots \ldots \ldots \ldots \ldots$ & 24.02 & 40.3 \\
\hline $\mathrm{Ag}_{2} \mathrm{O} \ldots \ldots \ldots \ldots \ldots \ldots \ldots \ldots \ldots \ldots$ & 24.32 & 18. 0 \\
\hline $\mathrm{CaO} \ldots \ldots \ldots \ldots \ldots \ldots \ldots$ & 7.54 & 23.2 \\
\hline $\mathrm{Na}_{2} \mathrm{O} \quad \ldots \ldots \ldots \ldots \ldots \ldots$ & 0.74 & 2.1 \\
\hline \multirow{2}{*}{ 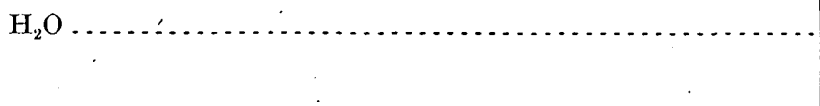 } & 8.39 & 80.0 \\
\hline & 100.00 & $\cdot$ \\
\hline
\end{tabular}


The reaction here is incomplete, but the thomsonite ratios have been fairly well preserved.

As the water of this mineral is ustally considered to form no part of the chemical molecule, in the following formula it has been represented separately.

For this and the two minerals to follow, the formule proposed by F. W. Clarke have been adopted, regarding them as mixtures of salts of orthosilicic and trisilicic acids. The analysis gives the subjoined ratios:

$$
18 \mathrm{Ag}_{2} \mathrm{O}, 23 \mathrm{CaO}, 2 \mathrm{Na}_{2} \mathrm{O}, 40 \mathrm{Al}_{2} \mathrm{O}_{3}, 100 \mathrm{SiO}_{2}, 80 \mathrm{H}_{2} \mathrm{O} \text {. }
$$

Combining monoxide bases, we have

$$
\mathrm{R}^{\prime \prime}{ }_{43} \mathrm{Al}_{80} \mathrm{Si}_{100} \mathrm{O}_{363} .80 \mathrm{H}_{2} \mathrm{O}
$$

which gives a ratio of orthosilicic to trisilicic acids of

$$
73 \mathrm{SiO}_{4}: 9 \mathrm{Si}_{3} \mathrm{O}_{8} \text {. }
$$

Substituting these, we have

$$
\mathrm{R}^{\prime \prime}{ }_{43} \mathrm{Al}_{80}\left(\mathrm{SiO}_{4}\right)_{73}\left(\mathrm{Si}_{3} \mathrm{O}_{8}\right)_{9} \cdot 80 \mathrm{H}_{2} \mathrm{O}
$$

and combining the two acid radicles under the indiscriminate symbol $\mathrm{X}$ we have

$$
\mathrm{R}^{\prime \prime}{ }_{43} \mathrm{Al}_{80} \mathrm{X}_{82} .80 \mathrm{H}_{2} \mathrm{O}=1-2-2,2 \mathrm{H}_{2} \mathrm{O} \text {. }
$$

The analysis of thomsonite reduced in the same way gives the formula

or, condensed,

$$
\mathrm{R}^{\prime \prime}{ }_{42} \mathrm{Al}_{85}\left(\mathrm{SiO}_{4}\right)_{76}\left(\mathrm{Si}_{3} \mathrm{O}_{8}\right)_{8} \cdot 98 \mathrm{H}_{2} \mathrm{O}
$$

$$
\mathrm{R}^{\prime \prime}{ }_{42} \mathrm{Al}_{85} \mathrm{X}_{84} \cdot 98 \mathrm{H}_{2} \mathrm{O}=1-2-2,2 \frac{1}{2} \mathrm{H}_{2} \mathrm{O} \text {. }
$$

\section{CHABAZITE.}

$\diamond$

The chabazite used in the following work was the well crystallized flesh-colored material from Wassons Bluff, Nova Scotia.

Two silver derivatives. were made, as follows:

A. Ammonium chabazite was heated in an open tube with four times its weight of dry silver nitrate for six hours at $300^{\circ} \mathrm{C}$.

B. Natural chabazite was heated in a sealed tube with four times its weight of dry silver nitrate for twenty-four hours at $250^{\circ}-290^{\circ} \mathrm{C}$.

Bull. $262-05-6$ 
C. Analysis of the original chabazite:

\begin{tabular}{|c|c|c|c|}
\hline . & $A^{\prime}$ & B. & C. \\
\hline $\mathrm{SiO}_{2} \ldots \ldots \ldots$ & 38.84 & 34.95 & 50: 78 \\
\hline 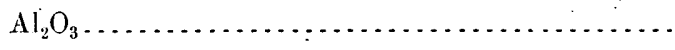 & 11.02 & 11.89 & 17. 18 \\
\hline $\mathrm{Fe}_{2} \mathrm{O}_{3} \ldots \ldots \ldots \ldots \ldots$ & & & .40 \\
\hline $\mathrm{Ag}_{2} \mathrm{O} \ldots \ldots \ldots \ldots \ldots \ldots \ldots$ & 28.95 & 39.63 & …. \\
\hline $\mathrm{CaO} \ldots \ldots . . . .$. & & ....... & 7. 84 \\
\hline $\mathrm{Na}_{2} \mathrm{O} \ldots \ldots \ldots \ldots$ & & .40 & 1.28 \\
\hline $\mathrm{K}_{2} \mathrm{O} \ldots \ldots \ldots \ldots \ldots$ & & ….. & .73 \\
\hline $\mathrm{H}_{2} \mathrm{O}-\ldots \ldots \ldots$ & & 2.38 & 5.22 \\
\hline $\mathrm{H}_{2} \mathrm{O}+\ldots \ldots$ & & 4. 40 & 16. 63 \\
\hline \multirow[t]{2}{*}{ 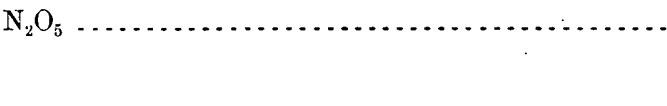 } & & 6.64 & \\
\hline & & 100.29 & 100.06 \\
\hline \multicolumn{4}{|l|}{ In the leach water: } \\
\hline $\mathrm{Al}_{2} \mathrm{O}_{3}, \ldots \ldots \ldots$ & & none & $\therefore$ \\
\hline $\mathrm{CaO}, \ldots \ldots \ldots$ & & 7.75 & \\
\hline $\mathrm{Na}_{2} \mathrm{O} \ldots \ldots$ & & 1.98 & \\
\hline
\end{tabular}

This preparation was light in color, showing that no appreciable amount of free silver oxide could have been present. It was decomposed easily by nitric acid, giving sandy silica.

The microscopic examination showed the material to be entirely crystalline and uniaxial.

In this, and as will be shown later in the thallium derivatives also, important amounts of $\mathrm{N}_{2} \mathrm{O}_{5}$ have been retained. This is not due to incomplete washing, but the nitrate is firmly held within the molecule. This same mineral gave, with ammonium chloride, a compound containing chlorine. What the presence of these small amounts of the acid radicles may mean is not known, but in the following reductions $\mathrm{N}_{2} \mathrm{O}_{5}$ will be considered as combined directly with silver or thallium; the proper amount will be subtracted from the analysis.

Deducting water below $100^{\circ}$ and also silver nitrate, analysis B becomes:

\begin{tabular}{|c|c|c|}
\hline & Residue B. & $\begin{array}{l}\text { Molecular } \\
\text { ratios. }\end{array}$ \\
\hline $\mathrm{SiO}_{2}$. & 45.30 & 100.0 \\
\hline $\mathrm{Al}_{2} \mathrm{O}_{3}$. & 15.41 & 20.0 \\
\hline $\mathrm{Ag}_{2} \mathrm{O}$. & 33.07 & 19.0 \\
\hline $\mathrm{Na}_{2} \mathrm{O}$. & .52 & 1.1 \\
\hline \multirow[t]{2}{*}{$\mathrm{H}_{2} \mathrm{O}$. } & 5.70 & 42.0 \\
\hline & 100.00 & \\
\hline
\end{tabular}


This gives the following molecular ratios:

$$
19 \mathrm{Ag}_{2} \mathrm{O}, 1 \mathrm{Na}_{2} \mathrm{O}, 20 \mathrm{Al}_{2} \mathrm{O}_{3}, 100 \mathrm{SiO}_{2}, 42 \mathrm{H}_{2} \mathrm{O} \text {. }
$$

Combining sodium with silver, we have

$$
\mathrm{R}_{20}^{\prime \prime} \mathrm{Al}_{40} \mathrm{Si}_{100} \mathrm{O}_{280} .42 \mathrm{H}_{2} \mathrm{O} \text {. }
$$

Hence the ratio between orthosilicic and trisilicic acids becomes

$$
10 \mathrm{SiO}_{4} \cdot 30 \mathrm{Si}_{3} \mathrm{O}_{8}
$$

and combining them under the symbol $\mathrm{X}$, the formula is

$$
\mathrm{R}^{\prime \prime}{ }_{20} \mathrm{Al}_{40} \mathrm{X}_{40} \cdot 42 \mathrm{H}_{2} \mathrm{O}=1-2-2,2 \mathrm{H}_{2} \mathrm{O} \text {. }
$$

Reducing the same way the analysis for chabazite, we have

$$
\mathrm{R}^{\prime \prime}{ }_{20} \mathrm{Al}_{40} \mathrm{X}_{40} .109 \mathrm{H}_{2} \mathrm{O}=1-2-2,5 \frac{1}{2} \mathrm{H}_{2} \mathrm{O} \text {. }
$$

The two formulie are

Native chabazite . $\mathrm{R}^{\prime \prime}{ }_{20} \mathrm{Al}_{40}\left(\mathrm{SiO}_{4}\right)_{10}\left(\mathrm{Si}_{3} \mathrm{O}_{8}\right)_{30} \cdot 109 \mathrm{H}_{2} \mathrm{O}$.

Silver chabazite $\mathrm{R}^{\prime \prime}{ }_{20} \mathrm{Al}_{40}\left(\mathrm{SiO}_{4}\right)_{10}\left(\mathrm{Si}_{3} \mathrm{O}_{8}\right)_{30} \cdot 42 \mathrm{H}_{2} \mathrm{O}$

Here calcium has been replaced by silver with a loss of three and one-half molecules of water.

The thallium derivatives were prepared with the same lot of chaba-

\begin{tabular}{|c|c|c|c|c|c|}
\hline \multirow[b]{2}{*}{ - } & \multicolumn{3}{|c|}{ D. } & \multicolumn{2}{|c|}{ E. } \\
\hline & $\begin{array}{l}\text { Residue } \\
\text { found. }\end{array}$ & $\begin{array}{l}\text { Residue } \\
\text { reduced. }\end{array}$ & $\begin{array}{l}\text { Molecu- } \\
\text { lar ratios. }\end{array}$ & $\begin{array}{l}\text { Residue } \\
\text { found. }\end{array}$ & $\begin{array}{l}\text { Ressdue } \\
\text { reduced. }\end{array}$ \\
\hline $\mathrm{SiO}_{2} \ldots \ldots$ & 28.92 & 36.31 & 100.0 & 29.44 & 34.44 \\
\hline $\mathrm{Al}_{2} \mathrm{O}_{3} \ldots \ldots \ldots \ldots \ldots \ldots \ldots \ldots \ldots \ldots \ldots \ldots$ & 10.75 & 13.50 & 21.8 & 11.11 & 13. 00 \\
\hline 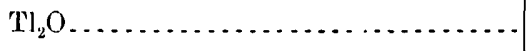 & 51.58 & 47.39 & 18.4 & 52. 11 & 49. 61 . \\
\hline $\mathrm{CaO} \ldots \ldots \ldots \ldots \ldots \ldots \ldots \ldots \ldots \ldots \ldots \ldots \ldots$ & .65 & .81 & 2.3 & .64 & .75 \\
\hline $\mathrm{Na}_{2} \mathrm{O} \ldots \ldots \ldots \ldots$ & $.28 \cdot$ & .35 & 1. 0 & .35 & .41 \\
\hline $\mathrm{H}_{2} \mathrm{O}+\ldots \ldots$. & 1.30 & 1.64 & 14.7 . & 1.53 & 1. 79 \\
\hline $\mathrm{H}_{2} \mathrm{O}-\ldots \ldots \ldots$ & 2.85 & …... & & 2.60 & . . . . . \\
\hline $\mathrm{N}_{2} \mathrm{O}_{5} \ldots \ldots \ldots \ldots \ldots \ldots \ldots \ldots$ & 3.54 & $\cdots$ & & 2.50 & ....... \\
\hline v & 99.87 & 100.00 & & 100.28 & 100.00 \\
\hline In the leach water: & & & & & \\
\hline $\mathrm{Al}_{2} \mathrm{O}_{3} \ldots \ldots$ & & & & None. & \\
\hline$\cdot \mathrm{CaO} \ldots . . . . .$. & ......... & & & 7.09 & \\
\hline $\mathrm{Na}, \mathrm{O} \ldots \ldots \ldots$ & 1. 54 & & & 1.58 & $\ldots$ \\
\hline
\end{tabular}
zite. Two preparations were made, as follows:

D. Chabazite was heated in a sealed tube with four times its weight of thallous nitrate, forty-eight hours at $250^{\circ}-290^{\circ} \mathrm{C}$.

E. Treated the same as D, but heated for sixty-seven hours. 
Both of these residues were perfectly white and entirely crystalline.

Thallium chabazite is easily decomposed with nitric acid, yielding sandy silica.

Derivative $\mathrm{D}$ gives the following ratios:

$$
18 \mathrm{Il}_{2} \mathrm{O}, 2 \mathrm{CaO}, 1 \mathrm{Na}_{2} \mathrm{O}, 22 \mathrm{Al}_{2} \mathrm{O}_{3}, 100 \mathrm{SiO}_{2}, 15 \mathrm{H}_{2} \mathrm{O} \text {; }
$$

or, combining monoxide bases,

$$
\mathrm{R}_{21}^{\prime \prime} \mathrm{Al}_{44} \mathrm{Si}_{100} \mathrm{O}_{287} .15 \mathrm{H}_{2} \mathrm{O} \text {. }
$$

The ratio of the two acid radicles is

$$
16 \mathrm{SiO}_{4}: 28 \mathrm{Si}_{3} \mathrm{O}_{8}
$$

and, inserting these in the formula, we have

or, condensed,

$$
\mathrm{R}^{\prime \prime}{ }_{21} \mathrm{Al}_{44}\left(\mathrm{SiO}_{4}\right)_{16}\left(\mathrm{Si}_{3} \mathrm{O}_{8}\right)_{28} \cdot 15 \mathrm{H}_{2} \mathrm{O}
$$

$$
\mathrm{R}^{\prime \prime}{ }_{21} \mathrm{Al}_{44} \mathrm{X}_{44} \cdot 15 \mathrm{H}_{2} \mathrm{O}=1-2-2+\mathrm{aq} .
$$

A rough experiment was made by heating silver chabazite in a sealed tube with a 10 per cent solution' of lead nitrate. The residue after washing and drying contained 5.59 per cent $\operatorname{Ag}_{2} \mathrm{O}$ and 20.24 per cent $\mathrm{PbO}$.

\section{STILBITE.}

The specimen of stilbite used came from Wassons Bluff, Nova Scotia. The action of silver nitrate upon this mineral was not investigated.

One thallium derivative was made by heating the stilbite in a sealed

\begin{tabular}{|c|c|c|c|}
\hline . & Stilbite. & Residue. & $\begin{array}{l}\text { Molecular } \\
\text { ratios. }\end{array}$ \\
\hline $\mathrm{SiO}_{2} \ldots \ldots \ldots \ldots \ldots$ & 55.41 & 36.75 & 100.0 \\
\hline $\mathrm{Al}_{2} \mathrm{O}_{3} \ldots \ldots \ldots \ldots \ldots \ldots \ldots \ldots$ & 16.85 & 11.74 & 18.8 \\
\hline $\mathrm{Fe}_{2} \mathrm{O}_{3} \ldots \ldots$ & .18 & $\ldots \ldots$ & . \\
\hline $\mathrm{Tl}_{2} \mathrm{O} \ldots \ldots \ldots$ & $\ldots .$. & 42.94 & 16.5 \\
\hline $\mathrm{CaO} \ldots \ldots \ldots \ldots \ldots \ldots \ldots \ldots$ & 7.78 & .68 & 2.0 \\
\hline $\mathrm{Na}_{2} \mathrm{O} \ldots \ldots$ & 1.23 & .15 & .3 \\
\hline 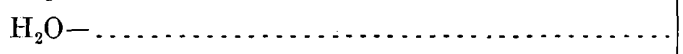 & 3.60 & 5.48 & \\
\hline \multirow[t]{2}{*}{ 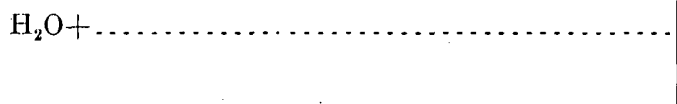 } & 15.41 & 2.29 & 20.8 \\
\hline & 100.46 & 100.03 & \\
\hline
\end{tabular}
tube with four times its weight of thallous nitrate sixty-five hours at $230^{\circ}-280^{\circ} \mathrm{C}$. The residue was perfectly white, entirely crystalline, and biaxial, and it gave sandy silica with nitric acid. The analysis follows: 
Omitting water lost below $100^{\circ}$, we have the following ratios:

$16 \mathrm{Tl}_{2} \mathrm{O}, 2 \mathrm{CaO}, 1 \mathrm{Na}_{2} \mathrm{O}, 19 \mathrm{Al}_{2} \mathrm{O}_{3}, 100 \mathrm{SiO}_{2}, 20 \mathrm{H}_{2} \mathrm{O}$;

and, combining monoxide bases,

$$
\mathrm{R}^{\prime \prime}{ }_{19} \mathrm{Al}_{38} \mathrm{Si}_{100} \mathrm{O}_{276}, 20 \mathrm{H}_{2} \mathrm{O}
$$

which gives a ratio between the two acid radicles of

$$
7 \mathrm{SiO}_{4}: 31 \mathrm{Si}_{3} \mathrm{O}_{8} \text {. }
$$

Inserting these in the formula, it becomes

$$
\mathrm{R}^{\prime \prime}{ }_{19} \mathrm{Al}_{38}\left(\mathrm{SiO}_{4}\right)_{7}\left(\mathrm{Si}_{3} \mathrm{O}_{8}\right)_{31} \cdot 20 \mathrm{H}_{2} \mathrm{O},
$$

which condenses to

$$
\mathrm{R}_{.19}^{\prime \prime} \mathrm{Al}_{38} \mathrm{X}_{38} \cdot 20 \mathrm{H}_{2} \mathrm{O} \text {. }
$$

Reducing the analysis of stilbite in the same way, we get

$$
\mathrm{R}^{\prime \prime}{ }_{17} \mathrm{Al}_{36}\left(\mathrm{SiO}_{4}\right)_{4}\left(\mathrm{Si}_{3} \mathrm{O}_{8}\right)_{32} .93 \mathrm{H}_{2} \mathrm{O}=1-2-2,5 \mathrm{H}_{2} \mathrm{O} \text {. }
$$

From the last three minerals we get the following formulæ:

Native thomsonite.............. $\mathrm{R}_{42}^{\prime \prime} \mathrm{Al}_{85}\left(\mathrm{SiO}_{4}\right)_{76}\left(\mathrm{Si}_{3} \mathrm{O}_{8}\right)_{8} \cdot 98 \mathrm{H}_{2} \mathrm{O}=1-2-2,2 \frac{1}{2} \mathrm{H}_{2} \mathrm{O}$.

Silver thomsonite .............. R $\mathrm{R}_{43}^{\prime \prime} \mathrm{Al}_{80}\left(\mathrm{SiO}_{4}\right)_{73}\left(\mathrm{Si}_{3} \mathrm{O}_{8}\right)_{9} \cdot 80 \mathrm{H}_{2} \mathrm{O}=1-2-2,2 \mathrm{H}_{2} \mathrm{O}$.

Native chabazite ................ $\mathbf{R}^{\prime \prime}{ }_{20} \mathrm{Al}_{40}\left(\mathrm{SiO}_{4}\right)_{10}\left(\mathrm{Si}_{3} \mathrm{O}_{8}\right)_{30} \cdot 109 \mathrm{H}_{2} \mathrm{O}=1-2-2,512 . \mathrm{H}_{2} \mathrm{O}$.

Silver chabazite ................ $\mathrm{R}_{20}^{\prime \prime} \mathrm{Al}_{40}\left(\mathrm{SiO}_{4}\right)_{10}\left(\mathrm{Si}_{3} \mathrm{O}_{8}\right)_{30} \cdot 42 \mathrm{H}_{2} \mathrm{O}=1-2-2,2 \mathrm{H}_{2} \mathrm{O}$.

Thalliun chabazite ............... R" ${ }_{21} \mathrm{Al}_{44}\left(\mathrm{SiO}_{4}\right)_{16}\left(\mathrm{Si}_{3} \mathrm{O}_{8}\right)_{28} .15 \mathrm{H}_{2} \mathrm{O} \doteq 1-2-2, \mathrm{Aq}$.

Native stilbite................. $\mathrm{R}^{\prime \prime}{ }_{17} \mathrm{Al}_{36}\left(\mathrm{SiO}_{4}\right)_{4}\left(\mathrm{Si}_{3} \mathrm{O}_{8}\right)_{92} \cdot 93 \mathrm{H}_{2} \mathrm{O}=1-2-2,5 \mathrm{H}_{2} \mathrm{O}$.

Thallium stilbite .............. R ${ }_{19} \mathrm{Al}_{38}\left(\mathrm{SiO}_{4}\right)_{7}\left(\mathrm{Si}_{3} \mathrm{O}_{8}\right)_{31} \cdot 20 \mathrm{H}_{2} \mathrm{O}=1-2-2, \mathrm{Aq}$.

The similarity of the foregoing formule is plainly evident. Leaving water out of consideration, and except in the single case of silver thomsonite, the ratios agree closely with the ratios of 1-2-2 for the monoxide base, aluminum, and silicic acid. It will be seen that with the two silver derivatives, compounds retaining two molecules' of water were formed, although in the case of thomsonite a mineral hydrated with $2 \frac{1}{2}$ molecules of water was taken, while the chabarite contained $5 \frac{1}{2}$.

\section{NATROIITE.}

The natrolite which was studied came from Bergen Hill, N. J. Two silver derivatives were made, as follows:

A. Natrolite was heated in a sealed tube with a 10 per cent solution of silver nitrate, eighteen hours at $120^{\circ} \mathrm{C}$.

B. Natiolite was heated in a sealed tube with four times its weight of dry silver nitrate, twenty-two hours at $250^{\circ}-290^{\circ} \mathrm{C}$. 


\begin{tabular}{|c|c|c|c|c|}
\hline & A. & B. & B. reduced. & $\begin{array}{l}\text { Molecular } \\
\text { ratios. }\end{array}$ \\
\hline $\mathrm{SiO}_{2} \ldots$ & 40.45 & 34.70 & 36.25 & 100.0 \\
\hline $\mathrm{Al}_{2} \mathrm{O}_{3} \ldots \ldots \ldots$ & 10.24 & 18.54 & 19.36 & 31.4 \\
\hline $\mathrm{Ag}_{2} \mathrm{O}$ combined. & 9048 & 32.30 & 33.73 & 24.0 \\
\hline $\mathrm{Ag}_{2} \mathrm{O}$ free $\ldots . .$. & & 3.91 & & \\
\hline $\mathrm{CaO} \ldots \ldots$. & .98 & 2.50 & 2.61 & 7.6 \\
\hline $\mathrm{Na}_{2} \mathrm{O} \ldots \ldots \ldots \ldots \ldots \ldots \ldots \ldots \ldots \ldots \ldots \ldots \ldots$ & 7.84 & .39 & .41 & 1.0 \\
\hline \multirow[t]{2}{*}{$\mathrm{H}_{2} \mathrm{O} \ldots \ldots \ldots \ldots \ldots \ldots \ldots \ldots$} & & 7.32 & 7.64 & 70.2 \\
\hline & & 99.66 & 100.00 & \\
\hline
\end{tabular}

Both preparations were very dark, showing that a quantity of free silver oxide had been deposited. The compound formed is easily decomposed by warm dilute nitric acid, giving a perfectly clear solution which gelatinizes upon evaporation. Under the microscope, it showed perfect crystallization.

Neglecting free silver oxide, residue $B$ gives the following formula:

$$
24 \mathrm{Ag}_{2} \mathrm{O}, 8 \mathrm{CaO}, 1 \mathrm{Na}_{2} \mathrm{O}, 31 \mathrm{Al}_{2} \mathrm{O}_{3}, 100 \mathrm{SiO}_{2}, 70 \mathrm{H}_{2} \mathrm{O} \text {, }
$$

or, combining monoxide bases,

$$
\mathrm{R}_{60}^{\prime} \mathrm{Al}_{62} \mathrm{Si}_{100} \mathrm{O}_{326}, 70 \mathrm{H}_{2} \mathrm{O} \text {, }
$$

which corresponds roughly to the formula $\mathrm{R}_{2} \mathrm{Al}_{2} \mathrm{Si}_{3} \mathrm{O}_{10} \cdot 2 \mathrm{H}_{2} \mathrm{O}$. The ratios are not so good as could be desired, but are close enough to show that this compound has probably been formed.

One thallium derivative was made by heating natrolite in a sealed tube with six times its weight of thallous nitrate for forty-eight hours,

\begin{tabular}{|c|c|c|}
\hline & Residue. & $\begin{array}{l}\text { Molecular } \\
\text { ritios. }\end{array}$ \\
\hline 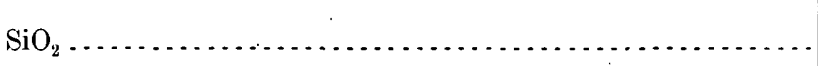 & 26. 10 & 100.0 \\
\hline 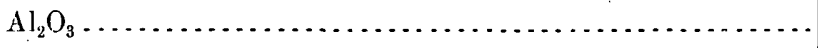 & 15.59 & 35.1 \\
\hline 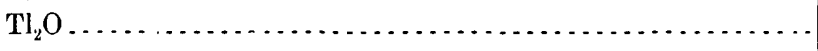 & 55.64 & 30.1 \\
\hline 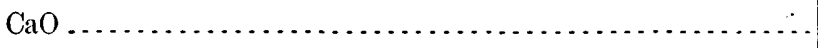 & .67 & 2.8 \\
\hline 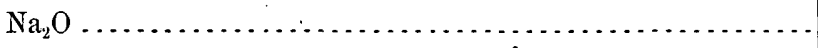 & .34 & 1. 1 \\
\hline 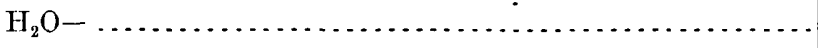 & .51 & \\
\hline \multirow{2}{*}{ 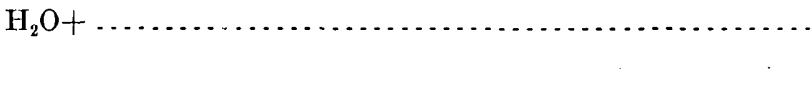 } & .66 & 8.5 \\
\hline & 99.51 & \\
\hline
\end{tabular}
at $250^{\circ}-290^{\circ} \mathrm{C}$. The analysis gave the following results: 
This compound is perfectly white. It is easily dissolved by dilute nitric acid, giving a perfect jelly on evaporation.

The optical observations were: Double refraction low, cleavage vertical, extinction parallel, probably biaxial. It was entirely crystalline. The molecular proportions are as follows:

$$
30 \mathrm{Tl}_{2} \mathrm{O}, 3 \mathrm{CaO}, 1 \mathrm{Na}_{2} \mathrm{O}, 35 \mathrm{Al}_{2} \mathrm{O}_{3}, 100 \mathrm{SiO}_{2}, 9 \mathrm{H}_{2} \mathrm{O}
$$

or, combining monoxide bases,

$$
\mathrm{R}_{68}^{\prime} \mathrm{Al}_{70} \mathrm{Si}_{100} \mathrm{O}_{339} \cdot 9 \mathrm{H}_{2} \mathrm{O} \text {, }
$$

which corresponds closely to the formula $\mathrm{R}_{2} \mathrm{Al}_{2} \mathrm{Si}_{3} \mathrm{O}_{10}$.

\section{SCOLECITE.}

The scolecite used came from Whale Cove, on the island of Grand Manan, New Brunswick.

One derivative was made by heating the scolecite in a sealed tube with four times its weight of silver nitrate six hours at $250^{\circ}-280^{\circ} \mathrm{C}$. The residue was dried at about $35^{\circ} \mathrm{C}$.

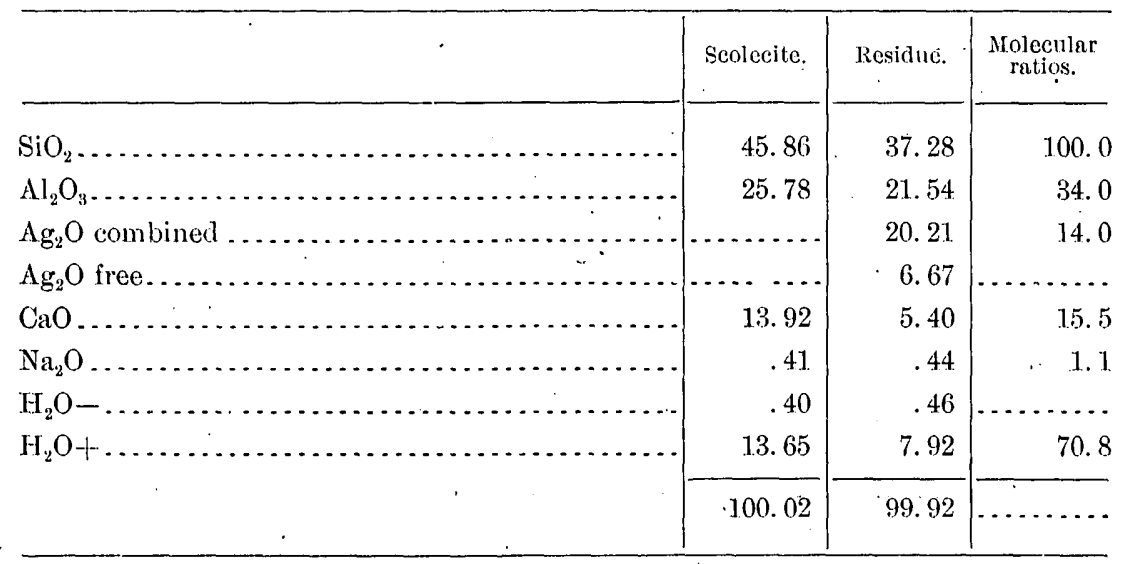

This residue was dark brown, owing to the silver oxide it contained. On heating over the low flime of the Bunsen burner in order to reduce the silver oxide to metallic silver it turned perfectly white.

On attempting to mount this preparation for microscopic examination the balsam became very dark, which prevented any optical observations from being made.

The molecular ratios for this derivative are:

$$
14 \mathrm{Ag}_{2} \mathrm{O}, 16 \mathrm{CaO}, 1 \mathrm{Na}_{2} \mathrm{O}, 34 \mathrm{Al}_{2} \mathrm{O}_{3}, 100 \mathrm{SiO}_{2}, 71 \mathrm{H}_{2} \mathrm{O} \text {, }
$$

or, uniting monoxide bases,

$$
\mathrm{R}_{62}^{\prime} \mathrm{Al}_{68} \mathrm{Si}_{100} \mathrm{O}_{333}, 71 \mathrm{H}_{2} \mathrm{O} \text {. }
$$


These proportions agree fairly well with the formula

$$
\mathrm{R}_{2}^{\prime} \mathrm{Al}_{2} \mathrm{Si}_{3} \mathrm{O}_{10} \text {, +aq. }
$$

The reaction in this case was incomplete, only a little over one-hal $\dot{f}$ the calcium and none of the sodium being replaced, but the experiment shows that the desired molecule was partially formed.

\section{MESOLITE.}

The mesolite studied was a fine specimen of crystalline material from Österö, in the Faroe Islands.

One thallium derivative was prepared by heating the mesolite in a sealed tube with four times its weight of dry thallous nitrate for eighty hours at $240^{\circ}-280^{\circ} \mathrm{C}$.

Its analysis and that of the mesolite follow:

\begin{tabular}{|c|c|c|c|}
\hline & Mesolite. & Residue. & $\begin{array}{l}\text { Molecular } \\
\text { ratios. }\end{array}$ \\
\hline $\mathrm{SiO}_{2} \ldots \ldots \ldots$ & 45.97 & 29.11 & 100.0 \\
\hline $\mathrm{Al}_{2} \mathrm{O}_{3} \ldots \ldots$ & 25.98 & 16.94 & 34.2 \\
\hline $\mathrm{Tl}_{2} \mathrm{O}$ & ........ & 44.75 & 21.7 \\
\hline $\mathrm{CaO} \ldots \ldots$ & 9.69 & 2.90 & 10.8 \\
\hline $\mathrm{Na}_{2} \mathrm{O} \ldots \ldots \ldots \ldots \ldots \ldots \ldots \ldots \ldots \ldots \ldots \ldots$ & 4. 79 & .26 & .8 \\
\hline 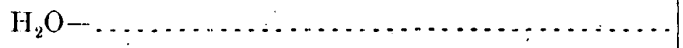 & 1.34 & 3.32 & \\
\hline \multirow[t]{2}{*}{ 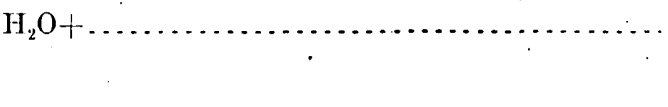 } & 12.04 & 3.06 & 35.0 \\
\hline & 99.81 & 100.34 & \\
\hline \multicolumn{4}{|l|}{ In the leach water: } \\
\hline $\mathrm{Al}_{2} \mathrm{O}_{3} \ldots \ldots \ldots$ & & None. & \\
\hline $\mathrm{CaO} \ldots \ldots \ldots \ldots$ & & 5.50 & \\
\hline $\mathrm{Na}_{2} \mathrm{O} \ldots \ldots \ldots \ldots \ldots$ & & 4.42 & $\ldots \ldots \ldots$, \\
\hline
\end{tabular}

The leached residue was perfectly white and entirely crystalline, with parallel extinction. It gave a perfectly clear solution with acid, which gelatinized on slight evaporation.

The molecular ratios are as follows:

$$
22 \mathrm{Tl}_{2} \mathrm{O}, 11 \mathrm{CaO}, 1 \mathrm{Na}_{2} \mathrm{O}, 34 \mathrm{Al}_{2} \mathrm{O}_{3}, 100 \mathrm{SiO}_{2,}, 35 \mathrm{H}_{2} \mathrm{O} \text {. }
$$

Combining monoxide bases, we have

$$
\cdot \mathrm{R}_{68}^{\prime} \mathrm{Al}_{68} \mathrm{Si}_{100} \mathrm{O}_{336} \cdot 35 \mathrm{H}_{2} \mathrm{O}
$$

agreeing almost perfectly with the formula

$$
\mathrm{R}_{2}^{\prime} \mathrm{Al}_{2} \mathrm{Si}_{3} \mathrm{O}_{10} \cdot \mathrm{H}_{2} \mathrm{O} \text {. }
$$


These three minerals and their derivatives give the following comparison, when all the monad and dyad bases are united under $\mathrm{R}^{\prime \prime}$ :

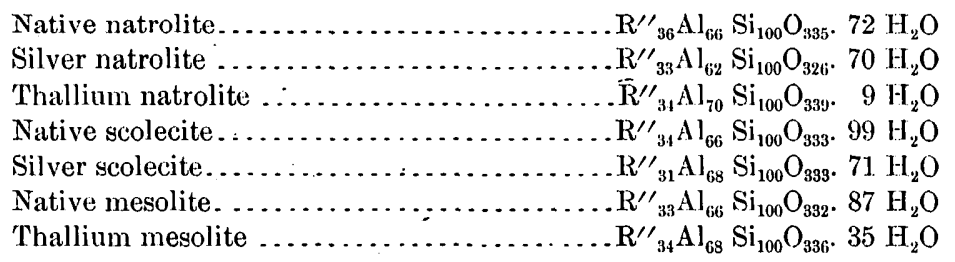

Since, as others have shown, the water in these three minerals plays no part in the chemical molecule, it has been placed as a separate constituent in the formula.

The rations found are not so sharp as could be desired, nor have the reactions been complete, but they indicate that the three minerals are all derived from the trisilicic acid $\mathrm{H}_{8} \mathrm{Si}_{3} \mathrm{O}_{10}$.

Deducting from each of the above formula the water contained in the undecomposed mineral, which latter is represented by the amount of alkali retained by the derivative, we have the water contents:

Silver natrolite ................ $70 \mathrm{H}_{2} \mathrm{O}$ less $18 \mathrm{H}_{2} \mathrm{O}$ equals $52 \mathrm{H}_{2} \mathrm{O}$

Thallium natrolite .............. $9 \mathrm{H}_{2} \mathrm{O}$ less $8 \mathrm{H}_{2} \mathrm{O}$ equals $1 \mathrm{H}_{2} \mathrm{O}$

Silver scolecite .................. $71 \mathrm{H}_{2} \mathrm{O}$ less $50 \mathrm{H}_{2} \mathrm{O}$ equals $21 \mathrm{H}_{2} \mathrm{O}$

Thallium mesolite .................35 $\mathrm{H}_{2} \mathrm{O}$ less $29 \mathrm{H}_{2} \mathrm{O}$ equals $6 \mathrm{H}_{2} \mathrm{O}$

We have here, as was the case with the thomsonite, chabazite, and stilbite derivatives, silver compounds strongly hydrated, while the thallium salts are practically anhydrous.

\section{PECTOLITE.}

The pectolite came from Bergen Hill, N. J. It contained a small amount of calcium carbonate as an impurity.

A single silver derivative was made by heating the pectolite in a sealed tube with four times its weight of dry silver nitrate, for twentytwo hours at $240^{\circ}-280^{\circ} \mathrm{C}$. The residue was dried on the water bath. On analysis the following results, stated below, were obtained.

\begin{tabular}{|c|c|c|c|}
\hline & Pectolite. & Residue. & $\begin{array}{l}\text { Moleculur } \\
\text { ratios. }\end{array}$ \\
\hline $\mathrm{SiO}_{2} \ldots \ldots \ldots \ldots \ldots \ldots \ldots \ldots$ & 53. 34 & 39.05 & 100.0 \\
\hline $\mathrm{Al}_{2} \mathrm{O}_{3} \ldots \ldots \ldots \ldots \ldots \ldots \ldots \ldots \ldots \ldots \ldots$ & .33 & .38 & $\cdots \cdots$ \\
\hline $\mathrm{Ag}_{2} \mathrm{O} \ldots \ldots \ldots \ldots \ldots \ldots \ldots \ldots \ldots \ldots \ldots \ldots$ & …...... & 32.57 & 21.5 \\
\hline $\mathrm{CaO} \ldots \ldots \ldots \ldots \ldots$ & 33.23 & 18. 1.3 & 49.8 \\
\hline $\mathrm{MnO} \ldots \ldots \ldots \ldots$ & .45 & $\ldots \ldots$ & $\ldots .$. \\
\hline $\mathrm{Na}_{2} \mathrm{O} \ldots \ldots \ldots \ldots \ldots \ldots \ldots$ & 9.11 & 5. 99 & 14.9 \\
\hline 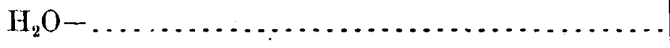 & .27 & & $\ldots \ldots$ \\
\hline $\mathrm{H}_{2} \mathrm{O}+\ldots \ldots \ldots \ldots \ldots \ldots \ldots \ldots \ldots \ldots \ldots \ldots \ldots \ldots \ldots \ldots \ldots \ldots$ & 2.70 & 4. 12 & 35.2 \\
\hline \multirow[t]{2}{*}{$\mathrm{CO}_{2} \ldots \ldots \ldots$} & .67 & & \\
\hline & 100.10 & 100.24 & \\
\hline
\end{tabular}


The derivative was dark, but on heating over the bunsen burner the color. disappeared, and on treating the ignited residue with nitric acid red fumes were given off, showing that a quantity of free silver oxide was present. This was not determined, but is contained in the figures given for $\mathrm{Ag}_{2} \mathrm{O}$. The silver oxide reported is therefore several per cent too high.

The compound is easily decomposed by warm dilute nitric acid, with the separation of sandy silica. A complex breaking up of the molecule has taken place and no simple ratios appear.

\section{ELAEOLITE.}

Elæolite from Litchfield, Me., was heated in the usual way with thallous nitrate. An incomplete analysis of the leached residue gave the following results:

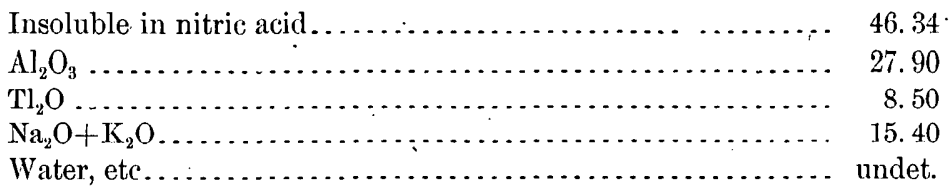

In the leach water was found 2.13 per cent of sodium and potassium oxides. The analysis shows that elæolite is but slightly attacked by treatment with thallous nitrate.

\section{AEGIRITE.}

Egirite from Magnet Cove, Arkansas, 'was heated in a sealed tube with dry silver nitrate. The following results were obtained on analysis of the leached residue:

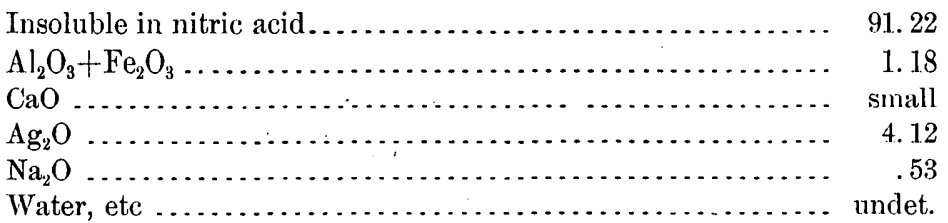

This mineral has evidently been but little altered by the action of silver nitrate. 


\section{DUMOR'IIERITE.}

\section{By Waldemar T. SchatlLer.}

\section{IN'TRODUC'IION.}

Dumortierite was discovered by Gonnard ${ }^{a}$ in November, 1879, at Chaponost, near Lyons, France, and was made the subject of a brief note by E. Bertrand in 1880. The following year, Gonnard named the mineral after Eugene Dumortier, the eminent French paleontologist.

The mineral was known to be new from its optical properties before its chemical composition was determined, its beautiful pleochroism being especially marked. Damour soon after made an analysis of the mineral, from which he obtained the formula $4 \mathrm{Al}_{2} \mathrm{O}_{3}, 3 \mathrm{SiO}_{2}$.

Specimens of this mineral from New York, previously taken for indicolite, were studied by Diller and Kiggs and shown to be different from tourmaline. At about the same time dumortierite from Arizona became known, and analyses of the mineral from both localities were made. These analyses all showed the presence of boric acirl in varying amounts, and also a small quantity of water. An occurrence of dumortierite in Norway was afterward noted, and still later several localities in Germany were mentioned.

In 1902, Ford published three analyses of dumortierite, one on material from New York, a second on material from Arizona, and a third on material from a new locality in San Diego County, Cal. In the same paper he mentions a second new locality, the fourth one in this country, in Skamania County, Wash. He showed by his analyses that dumortierite contains boric acid and water in nearly constant amount.

A careful search for crystals was made in a large quantity of the California mineral, which resulted in the finding of two small, imperfect but measurable examples. On looking over the Arizona material in the National Museum a third crystal was found. Three crystals were also obtained among specimens from New York. These were carefully measured and some crystallographic data were thus obtained.

The mineral is usually sparingly present in small fibrous masses scattered through the rock, making it difficult to obtain any consider- 
able quantitys of it in a pure condition. At the California locality the mineral occurs in large, pure masses, very favorable for chemical investigation. From an analysis made by the writer on the California material, a formula was deduced in which the boric acid and water have a certain fixed value. The other analyses are discussed, and it is shown that they all agree fairly well with the new formula proposed by the writer. An analysis of the Washington dumortierite is also given. Ford tested the French material qualitatively for boric acid and obtained a strong positive reaction.

While a more or less complete study of the mineral has been made, it is fully realized that in no sense can the work be called complete. The material for crystallographic study was poor, and it is very much hoped that better crystals will at some future time be found. The determinations of optical constants are very meager, for the usual condition of occurrence of the mineral is not favorable to such study. Only a few analyses are available for any discussion of the composition. of the mineral, and though dumortierite does not contain a large number of constituents, many more analyses-but only extremely accurate and reliable ones-will be gladly welcomed.

It was found that the California material differed somewhat in its properties from normal dumortierite. The color is lavender instead of blue, the pleochroism is colorless to red purple instead of blue, and the mineral contains $1 \frac{1}{2}$ per cent titanium oxide. It is of especial interest to correlate these differences, as it adds another good example to that class of silicates which contain a small amount of titanium and (seemingly thereby) acquire a purple pleochroism.

\section{OCCURRENCES.}

\section{FOREIGN.}

FRANCE.

Dumortierite ${ }^{a}$ is found at several places in the vicinity of Lyons (Rhone), where it occurs in a pegmatite gneiss. At Beaunan, on the road from Oullins to Chaponost, it is found in a small quarry in gneiss in slender blue fibers in the midst of veinlets or lenses of feldspar and pegmatite. At Brignais it occurs in very small fibers disseminated throughout a white pegmatite, associated with large black tourmalines, garnets, muscovite, and cordierite, the latter being largely altered to mica. In some cases bluish tourmaline and dumortierite have the vertical axis in common. Pseudomorphs of mica after dumortierite are frequent.

The mineral has a good. cleavage parallel to $a\{100\}$ and an imperfect prismatic one. There are also "planes of separation" parallel to the base. Twins, analogous to those of aragonite, are frequent. The 
color is blue, sometimes nearly black. Inclusions are not prominent, though bubbles and rutile have been noticed.

The axial plane is parallel to $b\{010\} . \quad \mathrm{Bx}_{\mathrm{a}}$ (negative) perpendicular to $c\{001\}$. In the twins the axial planes of the two parts make an angle of about $60^{\circ} . \quad \beta$ is about 1.65 , and the birefringence is about .010. The axial angle $\left(2 \mathrm{~V}_{\mathrm{Na}}\right)$ is near $35^{\circ}$ to $40^{\circ}$. The dispersion is energetic $\rho<v$. Pleochroism is very strong; $k=\iota$, colorless or very pale blue; $a$, cobalt blue or violet. Some of the specimens from Brignais are of a rose-salmon color, a little redder than andalusite. The maximum absorption is (contrary to that of tourmaline) in the direction of elongation (parallel to $c$ ). The presence of idiophanous figures is also noted. According to Damour, the blue color of the mineral yay perhaps be due to traces of $\mathrm{Ti}_{2} \mathrm{O}_{3}$, the presence of which in the French mineral has, however, not been demonstrated. It is noticed that the small fibers of dumortierite are often inclosed in a white mica, which is gradually replacing the original mineral.

GERMANY AND AUSTRIA.

The mineral is found near Schmiedeberg, Silesia, ${ }^{a}$ in the pegmatite of the lower Val Donbastone, in long fibers of a green or greenish- blue color. These fibers have a thickness of $1 \mathrm{~mm}$. and reach a maximum length of $50 \mathrm{~mm}$. They are often bent, and inclose pieces of quartz. On one fiber a prism angle of $69^{\circ} 6^{\prime}$ was measured. Prismatic cleavage, imperfect, was noted. The pleochroism is very strong: $\mathfrak{r}=\mathfrak{h}$, colorless; $a$, pistachio-green. Cross sections show the emergence of an acute bisectrix (negative), the axial angle being somewhat smaller than that of muscovite. With a crystal refractometer the following values for the indices of refraction were obtained:

$$
\begin{array}{r}
\alpha=1.678 \\
\beta=1.686 \\
\gamma=1.689 \\
\gamma-\alpha=.011
\end{array}
$$

An analysis of impure material was also made.

In a clayey residue, the mineral has been found at Imligan, near Chodan, and Schobrowitz, near Carlsbad, in Bohemia, and in clayey sandstone at Oberbris, near Pilsen, in Bohemia. These residues are probably formed from decomposing pegmatite, from which the dumortierite originally came. The mineral shows a strong pleochroism; $\dot{x}$, deep carmine to smalt blue and, in places where partly decomposed, dark olive to red brown; $\mathfrak{k}$, light gray olive to colorless. The (negative) acute bisectrix is parallel to the elongation. The obtuse bisectrix is perpendicular to the cleavage plates $(a=\{100\})$. The 
associated minerals are tourmaline, quartz, feldspar, muscovite, biotite, chrysoberyl, apatite, garnet, and chlorite.

\section{NORWAY.}

The mineial is found at Tvedestrand in minute fibers in cordierite gneiss. The pleochroism is as follows:

$$
\begin{aligned}
\mathfrak{r}=\mathfrak{l}, \text { pale yellow, almost colorless. } \\
\\
\mathfrak{x}, \text { intense cobalt blue. }
\end{aligned}
$$

Cross sections show a prismatic angle of about $60^{\circ}$. The birefringence $(.010)$ is feeble. Pleochroic halos (in yellow) are very characteristic. The axial angle $(2 \mathrm{~V})$ is about $35^{\circ}$, and the dispersion strong $\rho>v$. The associated minerals are cordierite and sillimanite.

Romberg has described a mineral from Argentina (2.51 per cent $\mathrm{B}_{2} \mathrm{O}_{3}$ ) which seems to resemble the California dumortierite. The color is lilac and the pleochroism similar to that from California.

\section{UNITED STATES.}

\section{NEW YORK.}

The mineral occurs in that part of New York City known as Harlem. It has been sparingly found as acicular crystals "aggregated in fasces or tufts resembling clippings of hair" in a lode of red granite extending southeastward from Fourth avenue and One hundred and twenty-third street to Madison avenue at One hundred and sixteenth street. At One hundred and seventy-first street and Fort $W$ ashington avenue it was found in several pockets in a vein of coarse pegmatite in mica-schist. The vein is about 3 feet wide and the pockets extended for about 80 feet. The body of the vein is granular gray quartz, orthoclase, and flaky muscovite. The dumortierite occurs chiefly in the orthoclase, though it has also been found as long, filiform inclusions in the muscovite, singly and radiating from centers. It has also been noticed at Kips Bay, near the upper end of Riverside Park, in white oligoclase; and at Tenth avenue and One hundred and thirtieth street.

The associated minerals are orthoclase, quartz, muscovite, xenotime, monazite, tourmaline, zircon, torbernite (?), antunite (?), apatite, garnet, and andalusite.

A brief study of several slides of the New York City dumortierite showed that the mineral occurs almost entirely in the orthoclase. Very rarely is it in the quartz or muscovite. It is usually in fibrous forms, with ragged outlines, and in one particular section an orthoclase crystal was filled with minute threads of dumortierite, arranged more or less parallel. In these slides andalusite also was noticed.

Mr. Frederick Braun, of Brooklyn, N. Y., very kindly lent the writer his private collection of New York dumortierite, which probably contains the finest dumortierite specimens ever found in that 
locality. About 25 specimens are shown, the best one containing a prismatic group of fine blue dumortierite fibers $5 \mathrm{~cm}$. long and from one-half to $1 \mathrm{~cm}$. thick. The rock is a pegmatitic gneiss, and consists chiefly of quartz and feldspar, with smaller quantities of biotite, muscovite, black tourmaline, dumortierite, and garnets. The dumortierite occurs in long prisms, often bent, and again broken, the space between being filled with the gneiss rock. The basal cross fracture is common and the color is often changed to a dull gray. At times the fibers are seemingly intergrown with the tourmaline in parallel position. The three crystals described later were obtained from these specimens.

As additional localities, Mr. Braun gives: One hundred and first street and Lexington avenue, New York; One hundred and eighteenth, One hundred and twentieth, One hundred and twenty-second streets and Madison avenue; One hundred and thirty-eighth, One hundred and thirty-ninth, One hundred and fortieth, One hundred and fortyninth streets and Mott avenue; One hundred and thirty-third, One hundred and thirty-fifth, One hundred and forty-ninth streets and Hudson River Railroad; One hundred and forty-ninth street and Sheerier place; One hundred and seventy-first street and Boulevard.

The mineral possesses a strong pleochroism, ranging from colorless to deep blue, this color being always in the direction of elongation. The extinction is parallel and the mineral orthorhombic. Cleavage parallel to the macropinacoid is perfect, these cleavage plates showing the emergence of an obtuse bisectrix. An imperfect cleavage parallel to the base is also noticed, and basal sections show an imperfect prismatic cleavage. Such sections show the emergence of an acute bisectrix. The mineral is negative. The axial plane is parallel to the brachypinacoid and the orientation is $a=\mathfrak{c}, b=\mathfrak{k}, c=\mathfrak{a}$. The pleochroism is $\mathfrak{r}=\mathfrak{l}$, colorless; $\mathfrak{a}$, deep blue. Absorption, $\mathfrak{a}>\mathfrak{r}=\mathfrak{r}$. Some sections show polysynthetic twinning lamellæ, but their relation could not be made out.

\section{ARIZONA.}

At Clip, Ariz., dumortierite occurs in a quartz rock which has not been found in place (Doctor Hillebrand), but only as loose bowlders. Dumortierite and quartz form the principal mineral constituents, kyanite, magnetite, and muscovite being present in subordinate amounts. The rock is fine grained and has a blue color due to the dumortierite.

Under the microscope, a section of the rock showed numerous small lath-shaped prisms of dumortierite placed in every direction in a mass of allotriomorphic quartz, with several large blades of muscovite and abundant magnetite, and a little apatite and rutile. Feldspar seems to be entirely absent.

The dumortierite has the usual colorless to blue pleochroism and presents normal properties. In the slide studied it is very fresh and shows no signs of alteration, the muscovite present being primary. 
The quartz grains are (relatively) fairly large and are not crushed like those of the California rock. The rock seems to have undergone. no dynamic change after its formation.

The pale-green kyanite has been analyzed by Dr. W. F. Hillebrand with the results given below:

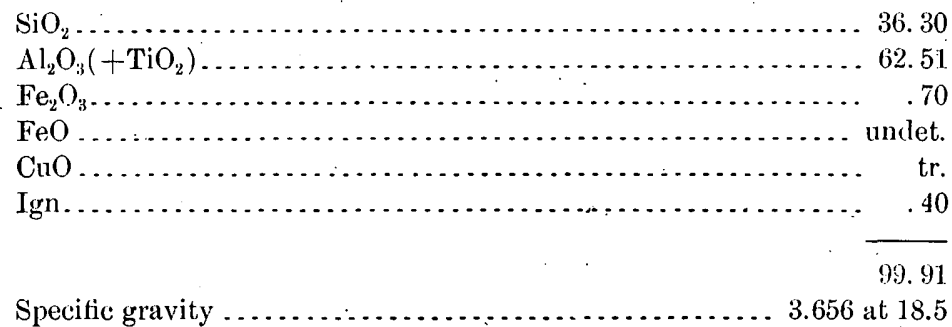

CALIFORNIA.

This occurrence was first mentioned by Ford, and an analysis of the dumortierite was given by him. The writer made a brief visit to the locality in the summer of 1903 and collected a large quantity of material, which permitted a rather complete study of the mineral. The writer's thanks are due to Mr. John A. Thoman, of San Diego, the owner of the property, for permission to visit the interesting locality and for the privilege of collecting specimens.

The mineral occurs in a dike a few miles east of Dehesa, San Diego County, and is not far from the orbicular gabbro described by Professor Lawson. ${ }^{a}$ 'ibe general country rock of the region is granite, in which occur large masses of gabbro, of which the orbicular rock is a peculiar phase. Both the gabbro and the granite contain many dikes, and it is in one of these dikes, in decomposed biotite-granite, that the dumortierite occurs. This dike has a length of about 1,000 feet and a thickness of about 30 or 40 feet, strikes S. $70^{\circ}$ E., and has a dip of about $70^{\circ}$ N. $20^{\circ}$ E.

The rock consists chiefly of quartz and either sillimanite or dumortierite. Feldspar is entirely absent from the dike. The dike may be divided into an upper and lower part, according to the character of the rock. The upper part is fine grained and consists of quartz and sillimanite; the lower part is coarse grained and consists of quartz and dumortierite.

The upper part, forming about one-half the dike, is a fine-grained white saccharoidal rock, sometimes of a grayish color, and never contains any dumortierite. It possesses a more or less schistose structure and cleaves off into blocks parallel to the dip. A little muscovite is sometimes present, small crystals of titanium oxide are abundant, and occasionally a little pyrite is seen. 
Microscopically the rock is composed of allotriomorphic quartz, sillimanite prisms arranged in parallel bands (schistose structure), a little muscovite, probably secondary, and accessory titanite, titanium oxide, rutile (?), pyrite, apatite, zircon, and corundum.

The sillimanite occurs both as short and long prisms. The former are usually grouped together in parallel bands which may run across the entire slide or may pinch out at both ends, forming a very flat lens. The prisms are short and stout, usually more or less ragged in outline, with many transverse fractures. The several parts of a single prism thus broken are at times considerably displaced. Again, an entire row of prisms may be broken and displaced. The displacement is always in the direction of elongation of the prism. The ends are usually more or less rounded, and macropinacoidal cleavage is sometimes well developed. Some nearly square cross sections show diagonal cleavage. Titanium oxide and zircon are at times inclosed in the prisms. These prisms occasionally show slight alterations and at times seem to have been entirely removed, forming either an opaque mass or leaving just the outlines of former prisms behind.

The long, slender prisms are placed at all angles and are not grouped in bands as the others are. The edges are sharp and the ends are often terminated by two faces, forming a spear. These prisms are usually smaller than the others and decrease in thickness until they are so narrow as to become entirely opaque. These straight hairlike inclusions were at first taken for rutile or magnetite, but it is thought they are merely sillimanite prisms of extreme thinness.

Optically the two forms are identical, and are to be classified as sillimanite. The relief is distinct and birefringence is rather strong. The direction of elongation is always an axis of minimum elasticity. The crystals are nonpleochroic and always extinguish parallel. Pleochroic halos were not observed.

The quartz is allotriomorphic and is usually much cracked. In general the principal cracks are parallel to the bands of sillimanite, while cracks perpendicular to these bands are also numerous. Many transverse irregular cracks also occur. Some of the quartz grains seem to have been slightly displaced, and the cracks thus formed been filled with secondary quartz. Sometimes the bands of sillimanite have caused "augen" to form. In places the quartz shows large liquid inclusions, and strings of small inclusions, though not common, sometimes occur. Besides the inclusions mentioned and the accessory minerals, the quartz contains in places a large amount of very fine opaque dust, possibly magnetite. Such sections of the quartz as remain dark under crossed nicols show a uniaxial cross with a positive sign in convergent light.

Of the accessory materials, titanium oxide, probably rutile, occurs in the greatest abundance. A few grains are probably titanite, but Bull. 262-05-7 
the majority of the small sharply defined crystals are probably rutile. They are at times slightly dichroic (yellow to brown), and occur in equidiametral erystals. Some of the crystals in the bands of sillimanite have been crushed and lengthened out. In one case a crystal of corundum was inclosed in rutile. Zircon is also widely distributed in irregular grains, usually of minute size. Occasionally a large piece has roughly the usual crystal outline, but seems to have been more or lesss corroded. 'One large crystal inclosed several small rutiles. The order of crystallization of the minerals seems to have been as follows: Corundum, rutile (and titanite), zircon, sillimanite, and quartz. It may be that there are two generations of sillimanite. Those long, slender sharp crystals in the quartz may have formed afte: the crystals in the bands.

An analysis of the rock was made by the writer, giving the results tabulated below:

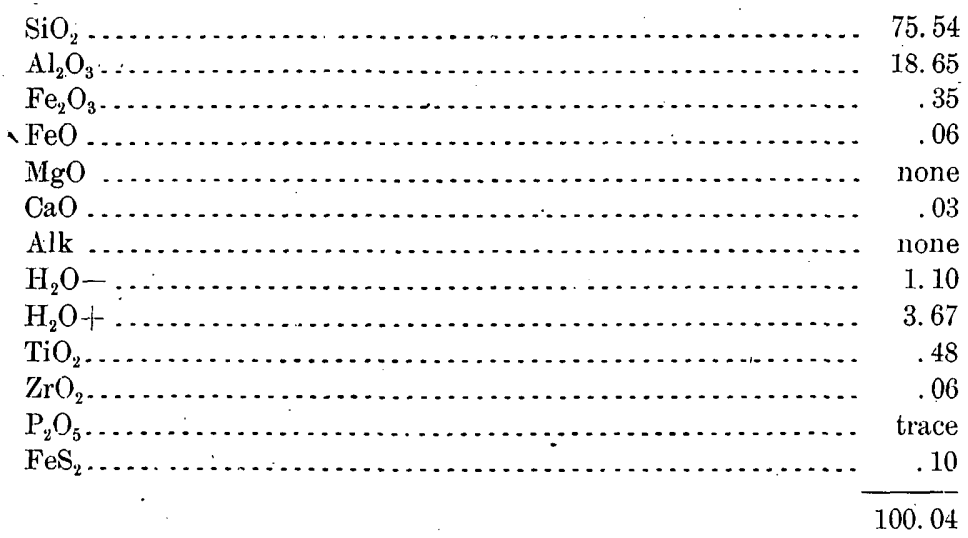

The large amount of water present is difficult to explain. Thè inclusions in the quartz account for some, and assuming the presence of some water due to incipient alteration in the sillimanite, there is still a large amount unaccounted for.

From the analysis, neglecting the water and accessory minerals, the composition of the rock is calculated as consisting of

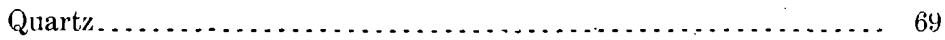

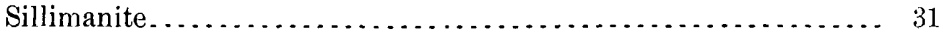

Deducting the water and other accessory minerals of the rock we obtain the following comparison:

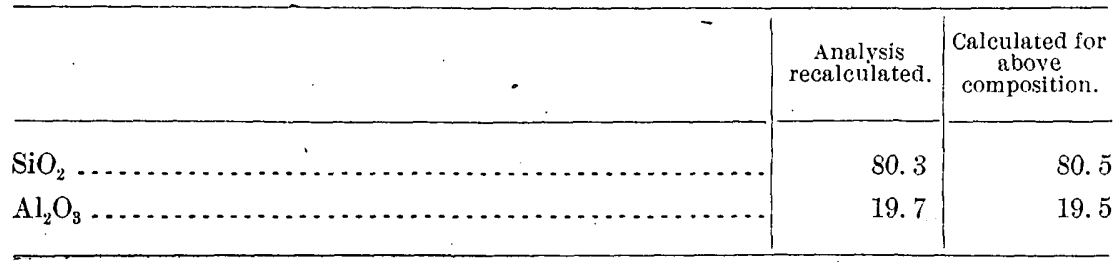


As we approach the middle of the dike the rock loses its schistose structure, becomes coarser, and we find occasional masses of dumortierite, which are more and more abundant, until finally we come to what is called the lower part of the dike, consisting of abundant dumortierite and quartz. Very rarely a small black tourmaline or garnet is seen. Muscovite is more or less abundant throughout the entire lower part, and in places forms an essential part of the rock.

The lower part of the dike differs in many ways from the upper. No schistose structure is apparent; the rock is very course and has a mottled appearance, due to the dark bunches ' of dumortierite on the white quartz background.

Some masses of dumortierite are very large, examples 5 by 3 by 3 $\mathrm{cm}$. being not uncommon. They úsually have a radiated columnar structure and break off nearly parallel to the base in fairly plane surfaces, which on large pieces become somewhat bowl shaped. As the various tibers are not strictly parallel but radiating, the breakage can only be approximately at right angles to the general elongation of the fibers. These masses of dumortierite weather from the rock and stand out very prominently. They usually have numerous cleavage cracks parallel to the base. The color of the mineral is lavender, resembling to some extent compact rubellite. Connected with this unusual color is the unusual pleochroism that the mineral possesses, being from colorless to red purple instead of blue.

The quartz is coarse grained and has a slight greasy appearance. It sometimes occurs in large masses free from dumortierite. Magnetite is present in small grains as well as titanium oxide-rutile (?). An analysis of a sample of pure quartz was made to prove the absence of any feldspar or other silicate. The analysis follows:

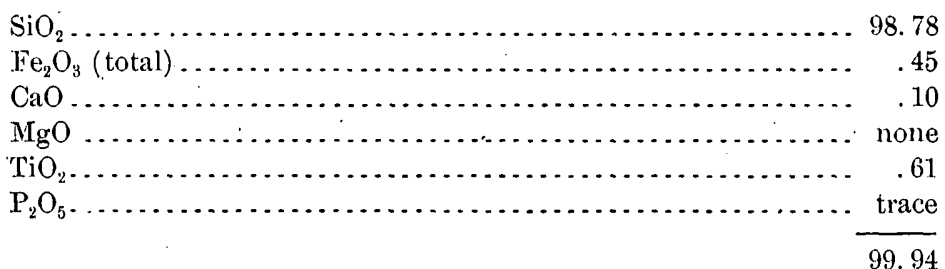

A rarer phase of the rock consists of quartz, muscovite, and dumortierite, which is here present in small pieces but a few millimeters or less thick. The mica is here an essential constituent of the rock and in places becomes abundant.

Microscopically the minerals present in the lower part of the dike are seen to be dumortierite and quartz, with muscovite and sillimanite in small quantities, together with accessory magnetite, titanite, rutile (?), apatite, and zircon, as well as a number of small undetermined inclusions. The dumortierite occurs in irregular masses with ragged outline, often resembling in shape the hornblende of a diorite. 
Again, it forms fan-shaped radiating masses, sometimes of large size. Irregular broken fibrous masses also occur scattered through the slide. The quartz is allotriomorphic and is but slightly cracked. It is rather full of inclusions in places. With the exception of a little muscovite there are no secondary minerals present.

The common form for the dumortierite is shown in radiated fanlike masses that vary considerably in size. When the entire piece is larger than a quadrant, parts of the black cross (seen in spherulites) are seen when the nicols are crossed. These fan-shaped pieces are probably the results of an incomplete spherulitic growth. The most perfect one consists of but halt a circle. On certain parts no radiated fibers are detectable, the (prismatic) cleavage lines being perfectly parallel. Some of the pieces become decidedly fibrous toward the ends, and the various individual fiber's depart somewhat from true parallelism. In between these fibers fine-grained aggregates of muscovite can often be seen.

A number of pieces showed a (secondary?) growth of tibers, which are probably in all cases dumortierite, as with high powers a faint pleochroism can be detected. They were at first thought to be sillimanite, but they agree in all their properties--so far as can be determined-with dumortierite. These fiber's can be classed in two parts.

Those in the first part seem to have been formed as a secondary growth on the main masses of dumortierite. The fibers branch out considerably and often form a radiating fringe around an entire section of the mineral. They penetrate the quartz grains, and interstitial muscovite is absent. 'The line where they join the main mass of the mineral is usually fairly well defined. In general, the fibers are normal to the edge of the main mass, but locally they vary considerably, especially where they form fanlike groups.

The fibers of the second class clearly represent a stage in the alteration of the dumortierite to muscovite. The solid mass of dumortierite becomes fibrous and, at the edges, breaks up into small fibers, which gradually become loose from the parent mass. The space where they formerly joined is now occupied by a granular mass of muscovite, which also fills the spaces between the fibers. Gradually this process goes on until, finally, we have a large mass of granular muscovite in which are embedded a few fibrous prisms of the original mineral. Fig. 6 shows diagrammatically a stage in the process.

Basal sections present an entirely different appearance. The macropinacoidal cleavage, so well developed on the New York mineral, does not show on the sections of the California mineral. The imperfect prismatic cleavage is present and divides the section up into a multitude of irregular bodies. Occasionally there is a short crack parallel to the brachypinacoid, and it may bo that the mineral possesses an imperfect interrupted brachypinacoidal cleavage. 
The prismatic cleavage was found to be parallel to the prism $\{210\}$. A large number of measurements gave as the angle $\{010\} \wedge$ cleavage cracks $62^{\circ}-67^{\circ}$, averaging $64^{\circ}-65^{\circ}$. The angle $\{010\} \wedge\{210\}$ is $66^{\circ} 01^{\prime}$. The cleavage cracks are irregular, and it was difficult to obtain any accurate measurements, but the ones made are sufficient to determine the cleavage. They were measured against the trace of the optic axial plane.

Polysynthetic twinning lamella were observed a number of times, and in one particular section (the same on which the prismatic cleavage was measured) were determinable to a certain extent. The alternate lamellæ extinguished together, the difference in angle of extinction of two adjacent lamella being about $31^{\circ}$. The line joining these lamella is parallel to the cleavage or to the prism $\{210\}$. The trace of the axial plane is parallel (or nearly so) in adjacent lamellae.

The pleochroism of the mineral is beautiful, especially if the section be not too thin. $t=a$ is colorless, $\mathfrak{l}=l$ is colorless to very faint pink, $a=c$ is deep-red purple. None of the sections entirely possess the ordinary blue pleochroism. In some slides, however, there are certain small areas of varied and irregular shape which do show the ordinary pleochroism. These small blue areas in the rich red-

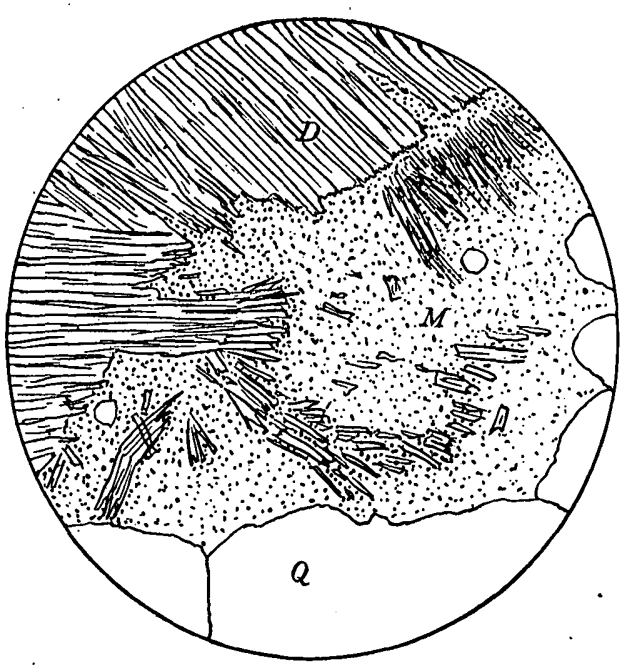

FIG. 6.-Dumortierite altering to muscovite. purple background make a most beautiful combination. On some sections a large area will have a faint bluish-purple color, as if intermediate between the deep-blue and the red purple.

This California dumortierite contains about $1 \frac{1}{2}$ per cent titanium oxide, which is considered as $\mathrm{Ti}_{2} \mathrm{O}_{3}$, replacing part of the alumina. Correlating these facts with the other known instances, it seems as if the presence of the titanium controlled the occurrence of this purple pleochroism. Samples of the Washington and Arizona mineral, free from titanite and rutile, and which possess the ordinary colorless to blue pleochroism, were tested qualitatively for titanium with hydrogen peroxide, with a negative result in each case. One might conclude, therefore, that in those areas of a dumortierite section in which the color is blue there is no titanium; that they are molecular centers, so to speak, which are free from titanium. The absorption of the mineral 
is $\mathfrak{a}>\mathfrak{h}=\mathfrak{c}$. Optically it is negative, the acute bisectrix $\mathfrak{a}$ being normal to the base. The axial plane is parallel to the brachypinacoid. The birefringence is higher than that of quartz, though only by a small amount.

The sections of dumortierite show that inclusions are rare. The masses of mineral are usually pure, muscovite being ábout the only mineral included, and this is not strictly an inclusion, as it is a secondary product, forming along the fibrous cracks of the mineral. In one basal section a number of rutile (?) crystals were observed, but such inclusions are verv rare.

The quartz occurs in large allotriomorphic grains, but little cracked and sometimes almost free from inclusions and again thickly crowded with them. In no way does the quartz show the effect of pressure as the quartz of the upper part of the dike does. Occasionally when the nicols are crossed the color of a quartz grain will be somewhat banded, these bands occurring on several grains, being parallel throughout the entire slide. The inclusions are sillimanite, magnetite, rutile (?), and an undetermined mineral.

The rock composing the dike is doubtless an igneous plutonic rock. There would seem to have been an interruption in the stage of formation of the entire dike. The upper or sillimanite-bearing part was more or less completely formed when a mass was pushed into the place now occupied by the lower part of the dike. This mass exerted a great pressure on the already partly formed upper part, giving it its schistose structure. Boric acid in large amount was in the lower mass. Possibly it was a later intrusion and may have caused the increase in pressure of the lower mass, which gradually cooled and formed a borosilicate (dumortierite) and quartz. The absence of dumortierite in the upper part would seem to indicate that the addition of boric acid to the entire mass was a later incident, and had the original magna cooled without this extra intrusion the rock would have been uniform and would have consisted of an aluminum silicate (sillimanite or andalusite) and quartz. The intrusion of the boric acid could not change the character of the upper part, which had already (at least partially) formed, but it did change the character of the lower part. May it be that the pressure determined the formation of sillimanite instead of andalusite?

\section{WASHINGTON.}

Ford mentions this occurrence of dumortierite and gives as the locality "the headwaters of the North Fork of the Washougal River in Skamania County, Wash." Mr. Brereton, of Woodstock, Oreg., very kindly sent the writer a number of specimens, which form the basis of the following notes.

As Ford states, the dumortierite occurs in a new habit, being present as small spherulites up to $3 \mathrm{~mm}$. in diameter. 
The rock in which they occur is a light-colored, fine-grained rock, containing, besides the blue spherulites, patches of a compact, soft; light-green mineral, shown to be muscovite. While the exposed surface of the rock is dark, the fresh portion light gray, rarely becoming almost white. Sometimes the dumortierite occurs so abundantly as to color the entire rock blue. Pyrite is also present and in places is very abundant.

Under the microscope the rock is seen to be very fine grained and to consist of quartz, muscovite, and andalusite in nearly equal proportions. The porphyritic spberulites of dumortierite form a striking feature in the fine-grained rock. The pale-green patches before mentioned are seen to be muscovite. Pyrite is abundant, and a few grains of magnetite (ilmenite?) surrounded by leucoxene are also present: In places the leucoxene is abundant.

The andalusite occurs as short laths with a square cross section and also as irregular more or less opaque masses without definite shape. They are probably in some stage of alteration, possibly to muscovite. While usually very minute, the laths occasionally become quite large relatively. In general, the andalusite surrounding the larger spherulites is much coarser than the main mass, though there are numerous exceptions. When clear and transparent, the laths exhibit the normal properties of andalusite. The relief is moderate and the birefringence low. Imperfect prismatic cleavage is sometimes seen. The prisms are nonpleochroic and pleochroic halos are absent. Extinction is always parallel. The elongation is always in the direction of maximum elasticity.

Sillimanite seems to be entirely absent. Muscovite occurs in the green masses and also in minute particles distributed throughout the entire rock. Nowhere does it occur in plates, as it normally does in granite, but everywhere it is in minute pieces. A good deal is probably derived from the alterations of the andalusite and dumortierite, and it may be possible that all of it is secondary - that the rock originally consisted essentially of quartz and andalusite. An analysis of the green mineral was made on a small amount of material, containing also some andalusite and quartz. It shows the mineral is muscovite, thus corroborating the microscopic evidence.

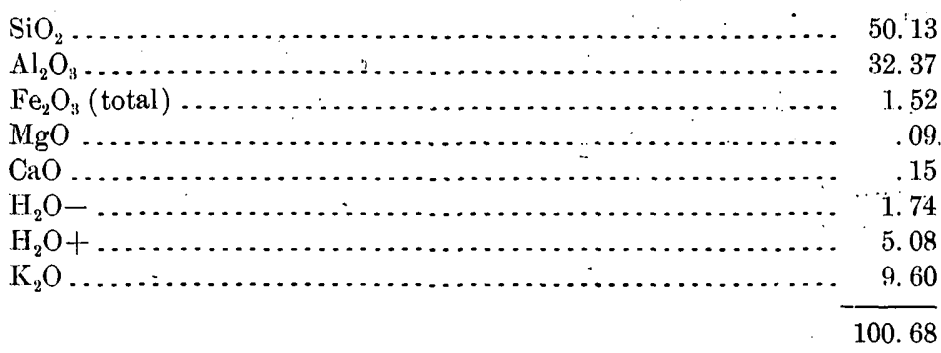

Specific gravity $\ldots \ldots \ldots \ldots \ldots \ldots \ldots \ldots \ldots \ldots \ldots \ldots \ldots \ldots \ldots \ldots \ldots \ldots, 2.80$ 
The quartz occurs in allotriomorphic grains, which are so minute and so mixed with the andalusite and muscovite that recourse was had to chemical analysis to verify their determination as quartz.

The dumortierite occurs in small spherulites scattered throughout the rock and occasionally bunched together to form a large patch of blue. On an average they reach a diameter of from one-half to $1 \mathrm{~mm}$. Their shape, while in general circular, is often ellipitical and may become very irregular in places. They consist of fibers radially arranged and show the optical phenomena of "spherulites." The dumortierite has parallel extinction, and its birefringence is somewhat higher than that of the quartz and also slightly more than that of

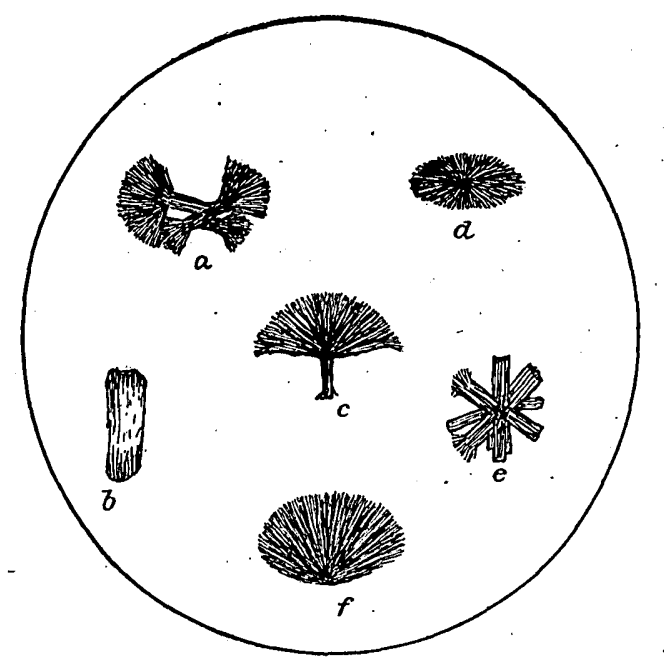

Fic. 7.-Forms of dumortierite. the andalusite, though the difference between that of the latter two minerals is very small.

The intensity of the pleochroism of the dumortierite varies, so that in some spherules there are concentric bands of fibers differing greatly in the depth of their color. Some spherules are almost colorless, and it was at first thought they might be parallel growths of andalusite with the dumortierite, but such a conclusion could not be verified.

The fibers are not always

perfectly radial. They are at times gathered into "brushes," and a number of these put together may form a spherulite. The fiber's are thus more thickly crowded in some places than elsewhere, and this frequently results in intensifying the pleochroism, so that in some spherulites there are numerous blotches of blue of much deeper color than the rest. Muscovite is frequently plentiful in a spherulite, being formed between the fibers, and is probably an alteration product of the dumortierite. Frequently a mass of dumortierite will be almost completely changed to mica, leaving but small fragments of the original mineral behind.

The fibers of dumortierite, while usually arranged radially, sometimes assume different shapes, and some of the masses of dumortierite seen under the microscope are reproduced in fig. 7 .

Fig. 7 shows variations from typical spherulitic form that the fibers of dumortierite assume. $a$ is four prisms irregularly joined at the 
center, the ends spreading out into "brushes" of fine fibers. This form is fairly abundant. $b$ forms a prismatic portion becoming fibrous at both ends, and while common in the New York, Arizona, and California occurrences, is a rare type for Washington dumortierite. $c$ forms a sort of fan and is composed of several "brushes" joined together. It is a common type. $d$ is an elliptical spherulite. $e$ is a mass of prisms such as $b$, but not spreading out as $a$ does. It is of rarer occurrence. $f$ is a bunch of radial fibers with'no prismatic stem as in $c$. It is fairly common.

To confirm the microscopical determination of the minerals of the rock a chemical analysis was made by the writer of a fresh sample of the rock. The results obtained are shown below.

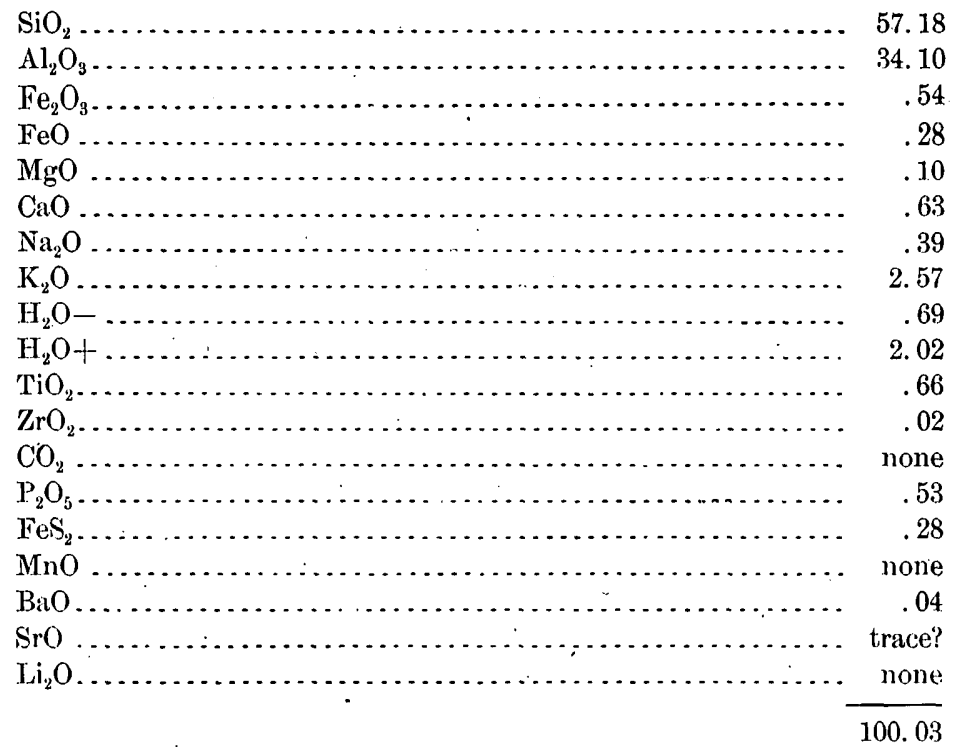

Out of 200 grams of rock, 4.3 grams of dumortierite were obtained. Some was doubtless lost, and the sample still contained some andalusite, but 2 to $2 \frac{1}{2}$ per cent would ipproximately represent the amount of dumortierite present.

The mineralogical composition of the rock is about as follows:

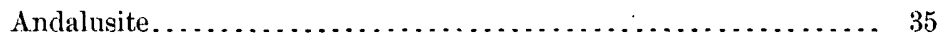

Dumortierite......................................... 2

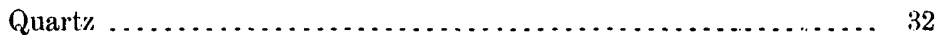

Muscovite ......................................... 27

Accessories $. \ldots \ldots \ldots \ldots \ldots \ldots \ldots \ldots \ldots \ldots \ldots \ldots \ldots, 4$ 
The accessories consist of pyrite, magnetite, possibly ilmenite, leucoxene, and apatite. Considering the dumortierite as andalusite and calculating the soda in the analysis as potash, we get the following comparison:

\begin{tabular}{|c|c|c|}
\hline : & $\begin{array}{l}\text { Calculated } \\
\text { composition. }\end{array}$ & Found. \\
\hline $\mathrm{SiO}_{2} \ldots \ldots \ldots \ldots \ldots \ldots \ldots \ldots \ldots$ & 57.66 & 57.18 \\
\hline $\mathrm{Al}_{2} \mathrm{O}_{3} \ldots \ldots \ldots \ldots \ldots \ldots \ldots \ldots \ldots \ldots$ & 33.81 & 34.10 \\
\hline $\mathrm{K}_{2} \mathrm{O} \ldots \ldots \ldots \ldots \ldots$ & 3.19 & 3.16 \\
\hline 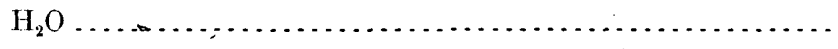 & 1. 22 & 2.02 \\
\hline 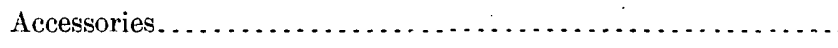 & 4.12 & 3.54 \\
\hline . & 100.00 & 100.00 \\
\hline
\end{tabular}

It is interesting to compare the minerals from the three western occurrences, where feldspar is entirely absent, and the rock in each case is composed (essentially) of the following materials:

Arizona: Dumortierite, quartz, muscovite, kyanite.

California: Dumortierite, quartz, muscovite, sillimanite.

Washington: Dumortierite, quartz, muscovite, andalusite.

As the three minerals, kyanite, sillimanite, and andalusite have the same chemical composition, the composition of the entire rock is ${ }^{\circ}$ probably also similar.

\section{CRYSTATIOGRAPIYY.}

While the writer was at the California locality he made special search for crystals of dumortierite, but is forced to the conclusion that good, perfect crystals of the mineral are yet to be found. A large quantity of seemingly promising material was collected and afterward carefully examined with a lens. One minute crystal was found showing several fairly good faces in the prismatic zone and, when mounted on the goniometer, presenting minute terminal planes giving poor reflections. Further search afforded another crystal showing several prismatic faces but no terminations.

The collection of specimens of dumortierite from Clip, A riz., in the United States National Museum, was examined, and on one specimen was found a small crystal showing two prism faces and a dome. Further, three small crystals were obtained from the New York mineral. On this poor material the following work is based. The results obtained are perhaps not accurate, but are the best that could be obtained. The California and New York crystals are long prismatic, while the Arizona crystal may be termed short prismatic. 
The mineral is orthorhombic, and from the various measurements the following axial elements have been calculated

$$
\begin{aligned}
\grave{a} & =.8897 \\
\grave{c} & =.6871
\end{aligned}
$$

The crystals were measured with the two-circle goniometer, and the values for $p_{0}$ and $q_{0}$, from which the above ratios are obtained, are

$$
\begin{aligned}
p_{0} & =.7723 \\
q_{0} & =.6871
\end{aligned}
$$

The forms observed are as follows:

$$
\begin{aligned}
b & =0 \infty=010 \\
a & =\infty 0=100 \\
l & =\infty 2=120 \\
m & =\infty=110 \\
g & =\frac{3}{2} \infty=320 \\
n & =2 \infty=210 \\
d & =\frac{1}{2} 0=102 \\
v & =\frac{2}{3} 0=203
\end{aligned}
$$

Besides these forms, reflections were obtained from several other minute faces, but they were so minute, and the reflections so poor, that their validity is very questionable and they are omitted from the foregoing list. The averages of the measured angles, compared with the calculated values, are shown in the' following table:

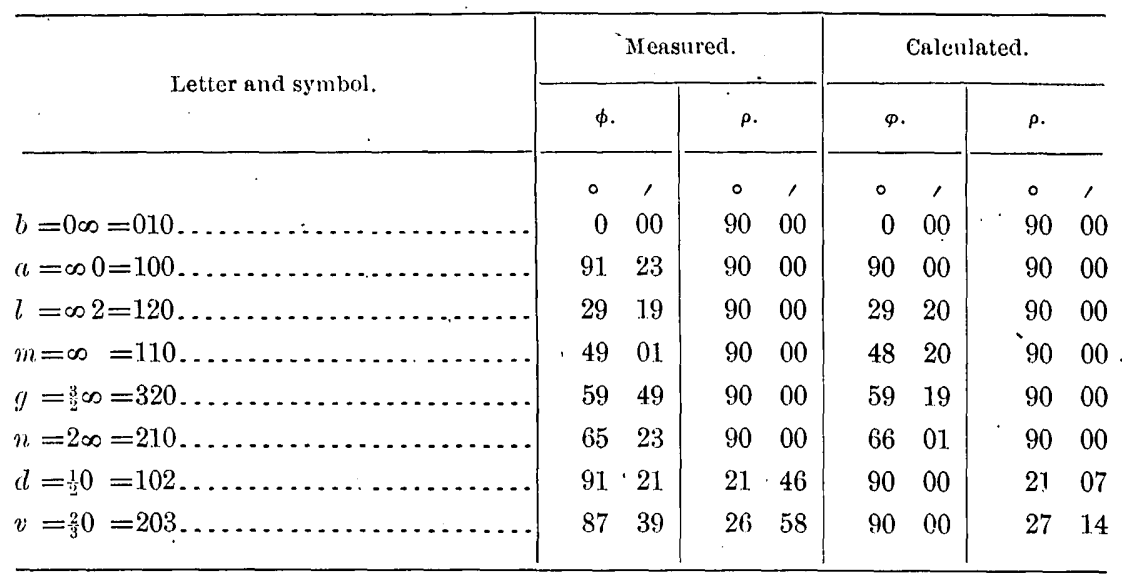


The brachypinacoid is present on four crystals, usually as broad faces. Some give relatively good reflections.

The macropinacoid occurs on all crystals, except the one from Arizona, and always as narrow faces. The reflections were poor, but serve to identify the form. The $\phi$ angles measured are as follows:

\begin{tabular}{|c|c|c|}
\hline & Measured. & Calculated. \\
\hline & & 。 \\
\hline California.. & $90 \quad 02$ & \\
\hline Do $\ldots \ldots, \ldots \ldots \ldots$ & $93 \quad 46$ & \\
\hline Do $\ldots \ldots \ldots \ldots \ldots \ldots$ & $90 \quad 00$ & an \\
\hline 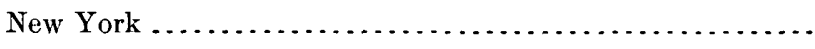 & $92 \quad 57$ & 9000 \\
\hline Do $\therefore \ldots \ldots \ldots \ldots$ & 9115 & \\
\hline Do $\ldots \ldots \ldots \ldots$ & $90 \quad 16$ & \\
\hline
\end{tabular}

The brachy prism $l=\infty 2=120$ occurs on four crystals as narrow faces giving fair reflections.

\begin{tabular}{|c|c|c|}
\hline & Measured. & Calculated. \\
\hline California............... & $\stackrel{\circ}{30} \quad{ }^{\prime}$ & $\circ$ \\
\hline Do $\ldots \ldots \ldots \ldots$ & $28 \quad 00$ & \\
\hline Do $\ldots \ldots \ldots \ldots \ldots$ & $29 \quad 22$ & 29 \\
\hline 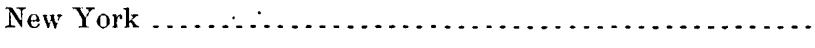 & $29 \quad 34$ & \\
\hline Do $\ldots \ldots \ldots \ldots \ldots \ldots$ & $29 \quad 39$ & \\
\hline
\end{tabular}

The unit prism is poorly developed on the California crystals, being present but once as a narrow face giving a poor reflection. On the Arizona crystal it occurs twice as broad faces.

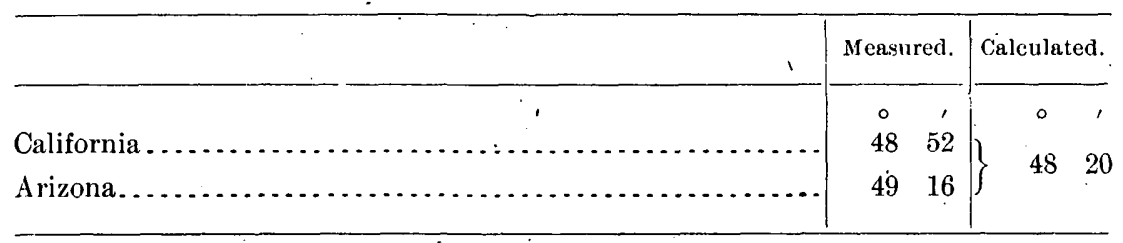


The macro prism $g=\frac{3}{2} \infty=320$ is present several times. The measured angles vary somewhat.

\begin{tabular}{|c|c|c|}
\hline & Measured. & Calculated. \\
\hline California $\ldots \ldots \ldots \ldots \ldots$ & $\begin{array}{cc}\circ & \prime \\
58 & 55\end{array}$ & \\
\hline 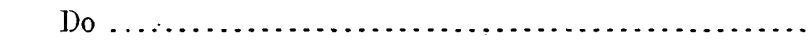 & $59 \quad 42$ & \\
\hline 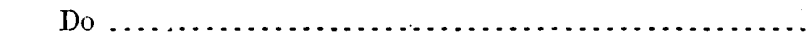 & 60 & \\
\hline 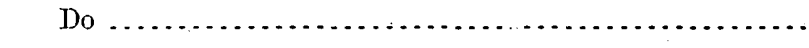 & 59 & \\
\hline 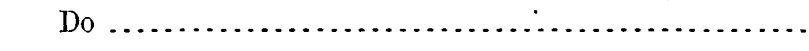 & 59 & \\
\hline 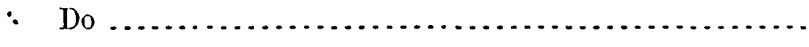 & $60 \cdot 14$ & $59 \quad 19$ \\
\hline New York ................. & 59 & \\
\hline 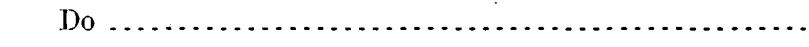 & 60 & \\
\hline 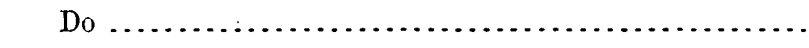 & $59 \quad 25$ & \\
\hline 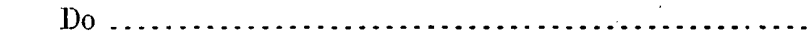 & 60.23 & \\
\hline 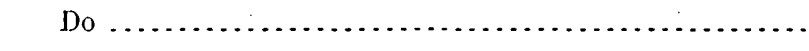 & 6031 & \\
\hline
\end{tabular}

The macro prism $n=2 \infty=210$ is present four times. The reflections were fair.

\begin{tabular}{|c|c|c|}
\hline - & Measured. & Calculated. \\
\hline California......... & $\begin{array}{cc}\circ & 1 \\
65 & 26\end{array}$ & $\circ$ \\
\hline 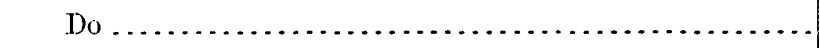 & $65 \quad 35$ & 66 \\
\hline 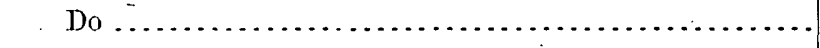 & $65 \quad 19$ & 00 \\
\hline Do & $65 \quad 12$ & \\
\hline
\end{tabular}

The macro dome $d=\frac{1}{2} 0=102$ is present once on the Arizona crystal. The reflections were not very good.

The dome $v=\frac{2}{3} 0=203$ is present on one of the California crystals. The face is exceedingly minute and the reflection was poor.

On crystal No. 4 (New York) were observed two very small faces, giving poor reflections.

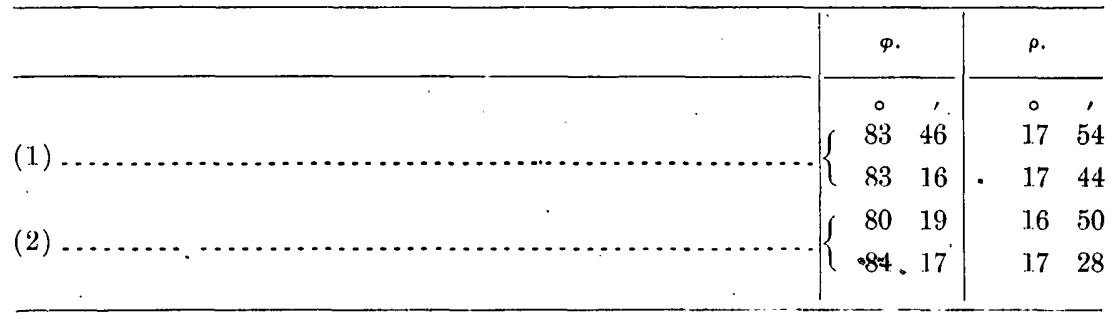

These agree approximately with the symbol $\{8.1 .20\}$, or considering the form vicinal to a dome, to $\{205\}$. 
The combinations seen on the six crystals are as follows:

\begin{tabular}{|c|c|c|}
\hline No. 1 & California & $l, a, \quad l,-, m, \quad g, n,-, \quad v$ \\
\hline No. 2 & California & $b, a, \quad l, h,-, g, n,-,-$ \\
\hline No. 3 & Arizona ... & $-,-,-,-, m,-,-, d,-$. \\
\hline No. 4 & New York. & $b, \quad a,--,-,-, \quad g,--,-,-$ \\
\hline No. 5 & New York .. & $b, \quad a, \quad l,-,-, \quad g,-,-,-$ \\
\hline No. 6 & New York .... & $-, \quad \dot{a}, \quad l,-,-, \quad g,-,-,-$. \\
\hline
\end{tabular}

Fig. $8^{\prime}$ shows three of the crystals. A is from California; size, $1 \mathrm{~mm} . \times \frac{1}{4} \mathrm{~mm}$. B is from New York; size, $1 \mathrm{~mm} . \times \frac{1}{2} \mathrm{~mm}$. C is from Arizona; size, $1 \mathrm{~mm} . \times 1 \mathrm{~mm}$.

The following table gives the calculation of the forms of dumortierite based on the elements given in this paper. The table corresponds to the forms given in Goldschmidt's Winkeltabellen.

\begin{tabular}{|l|r|r|r|r|r|}
\hline $\mathrm{a}=.8897$ & $\lg \mathrm{q}=9.94924$ & $\lg \mathrm{g}_{0}=0.11202$ & $\lg \mathrm{p}_{0}=9.88779$ & $\mathrm{a}_{0}=1.2943$ & $\mathrm{p}_{0}=.7723$ \\
\hline $\mathrm{c}=.6871$ & $\operatorname{lgc}=9.83702$ & $\lg \mathrm{b}_{0}=0.16298$ & $\lg \mathrm{q}_{0}=9.83702$ & $\mathrm{~b}_{0}=1.4554$ & $\mathrm{q}_{0}=.6871$ \\
\hline
\end{tabular}

\begin{tabular}{|c|c|c|c|c|c|c|c|c|c|c|c|c|c|c|c|c|c|c|}
\hline \multirow[b]{2}{*}{ No. } & \multirow{2}{*}{$\begin{array}{l}\text { Let- } \\
\text { ter. }\end{array}$} & \multicolumn{2}{|c|}{ Sym: } & \multirow{2}{*}{\multicolumn{2}{|c|}{$\phi}}$. & \multirow{2}{*}{\multicolumn{2}{|c|}{$\rho$. }} & \multirow{2}{*}{\multicolumn{2}{|c|}{$\xi_{0}$}} & \multirow{2}{*}{\multicolumn{2}{|c|}{$\eta_{0}}}$. & \multirow{2}{*}{\multicolumn{2}{|c|}{$\xi$}} & \multirow{2}{*}{\multicolumn{2}{|c|}{$\eta$}} & \multirow{2}{*}{$\begin{array}{c}x \\
(\text { Prism) } \\
x: y .\end{array}$} & \multirow[b]{2}{*}{$y$} & \multirow[b]{2}{*}{$\mathrm{d}=\operatorname{tg} \rho$} \\
\hline & & $\begin{array}{c}\text { Mil- } \\
\text { ler. }\end{array}$ & gdt. & & & & & & & & & & & & & & & \\
\hline & & & & & & 0 & , & & & $\circ$ & & & & & & & & \\
\hline 1 & $b$ & 010 & $0 \infty$ & 0 & 00 & 90 & 00 & 0 & 00 & 90 & 00 & 0 & 00 & 90 & 00 & 0 & $\infty$ & $\infty$ \\
\hline 2 & $a$ & 100 & $\propto 0$ & 90 & 00 & 90 & 00 & 90 & 00 & 0 & 00 & 90 & 00 & 0 & 00 & $\infty$ & 0 & $\infty$ \\
\hline 3 & $l$ & 120 & $\infty 2$ & 29 & 07 & 90 & 00 & 90 & 00 & 90 & 00 & 29 & 07 & 60 & 53 & .5570 & $\infty$ & $\infty$ \\
\hline 4 & $m$ & 110 & $\infty$ & 49 & 01 & 90 & 00 & 90 & 00 & 90 & 00 & 49 & 01 & 40 & 59 & 1.1510 & $\infty$ & $\infty$ \\
\hline 5 & $g$ & 320 & $\frac{3}{2} \infty$ & 59 & 47 & 90 & 00 & 90 & 00 & 90 & 00 & 59 & 47 & 30 & 13 & 1.7170 & $\infty$ & $\infty$ \\
\hline 6 & $n$ & 210 & $2 \infty$ & 65 & 23 & 90 & 00 & 90 & 00 & 90 & 00 & 65 & 23 & 24 & 37 & 2.1825 & $\infty$ & $\infty$ \\
\hline 7 & $d$ & 102 & $\frac{1}{2} 0$ & 90 & 00 & 21 & 07 & 21 & 07 & 0 & 00 & 21 & 07 & 0 & 00 & .3862 & 0 & 0.3862 \\
\hline 8 & $v$ & 203 & $\frac{2}{3} 0$ & 90 & 00 & 27 & 14 & 27 & 14 & 0 & 00 & 27 & 14 & 0 & 00 & .5147 & 0 & .5147 \\
\hline
\end{tabular}

The minerals andalusite, sillimanite, staurolite, and dumortierite possess certain properties that are very much alike. They are all orthorhombic, their axial ratios are similar, their principal constituents are silica and alumina, and in many ways these minerals can well be grouped together. 'Using the word isomorphous in its general loose sense, these minerals are isomorphous. A comparison of their axial ratios is given below:

\begin{tabular}{|c|c|c|}
\hline$\cdot$ & $\grave{a}$. & $\dot{c}$. \\
\hline Andalusite $\ldots$. & .9861 & .7025 \\
\hline Sillimanite ................ & $.970^{\circ}$ & $(?)$ \\
\hline Staurolite $\ldots \ldots \ldots \ldots \ldots \ldots \ldots \ldots$ & .9795 & .6942 \\
\hline 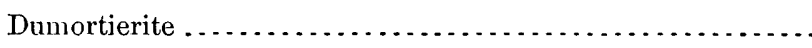 & .8897 & .6871 \\
\hline
\end{tabular}


For staurolite the values are taken from Goldschmidt's Winkeltabellen with the $a$ and $c$ axes interchanged.

There was some question in the writer's mind as to whether the orientation chosen was the best or whether the present prism $\{210\}$ had not better be made the unit prism. The cleavage is parallel to this prism, and the twinning also bears some relation to this form. Moreover, the ratio above given for: staurolite, though adopted by Goldschmidt, is not, in the writer's opinion, the best one for the mineral. The one given by Dana, who makes the $a$ axis just half as long, would be the better one. The common form of staurolite is prismatic, with a prism angle of $50^{\circ} 40^{\prime}$ (Dana).

For andalusite, on the other hand, the prismatic angle is $89^{\circ} 12^{\prime}$ and the $a$ axis should be .9861 , as given. Should dumortierite be classed crystallographically with staurolite or .with andalusite? Unfortunately, the evidence is almost too meager to decide this question. The unit prism is poorly developed on the California crystals and entirely absent from the New York, the strongest form next to the brachypinacoid being the prism $\{320\}$. The prismatic cleavage is parallel to $\{210\}$, and making the cleavage form the unit prism the $a$ axis should be given half its present value. On

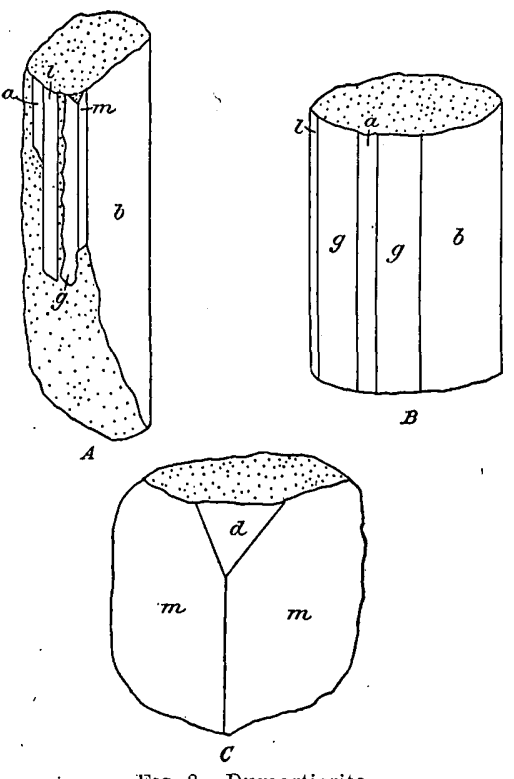

FIG. 8.-Dumortierite. the other hand, the Arizona crystal is of the typical andalusite habit, and, making the prism the unit one, we obtain the axes as here given. Giving staurolite the (approximate) same axes as andalusite and dumortierite, the prismatic cleavage is parallel to the same form as in dumortierite $\{210\}$.

It may be worth noting that as staurolite and dumortierite are related crystallographically more closely than either with andalusite, the chemicil composition of the two former is much more complex than that of the last named species.

\section{PHYSICAL PROPERTIES. \\ GENERAL PROPE'TIES.}

Macroscopic crystals are exceedingly rare, the mineral usually occurring in prismatic fibrous forms showing no crystal faces. The Washington mineral occurs in spherulitic forms which are but a special arrangement of fibers. 
The cleavage is-macropinacoidal good, prismatic $\{210\}$ imperfect, and basal imperfect, and perhaps, also, in traces, brachypinacoidal. The New York mineral shows the macropinacoidal cleavage very well, while the California mineral shows the imperfect basal cleavage. The fracture is rough and the fibrous prisms are somewhat brittle, though a mass of fibers is very tough. The bardness is 7 .

The following values for the specific gravity have been given:

$-3.265$

- 3.22

$3.226-3.43$

$3.211-3.302$

Av. 3.292

The writer obtained 3.306 as the density of a piece weighing about 10 grams. 'A good average value would be 3.30 .

The luster is vitreous, somewhat sutiny on the fibrous California mineral. The color is usually blue, though also lavender and greenish blue to black. The colors noted are:

France: Blue, black.

Germany: Blue, bluish green.

Sweden: Blue.

New York, Arizona, Washington: Blue.

California: Lavender.

The mineral is usually opaque in its massive form, but the small fibers of the California mineral are transparent to translucent.

\section{OPTICAL CHARACTERS.}

All the determinations made on the mineral from different localities have given the same orientation. The axial plane is parallel to the brachypinacoid, the acute bisectrix is normal to the base. The mineral is negative.

The following are the pleochroisms noted on the mineral from different localities: Colorless to cobilt blue, pale yellow or colorless to cobalt blue, colorless to pistachio green, colorless to rose salmon, colorless to deep carmine, colorless to red purple (California).

AXIAL ANGLES:

On the Norway mineral, $2 \mathrm{~V}_{\mathrm{Na}}$ was determined as about $35^{\circ}$. Linck states that the angle is somewhat less than that of muscovite. 
The axial angle on the California dumortierite is small. The following measurements were made with the microscope and micrometer ocular, and represent only approximate values:

$$
\begin{aligned}
& 2 \mathrm{E}_{\mathrm{Ii}}=33^{\circ} \\
& 2 \mathrm{E}_{\mathrm{Na}}=37 \\
& 2 \mathrm{E}_{\mathrm{Cu}}=42
\end{aligned}
$$

The dispersion thus is $\rho<v$.

$$
\text { INDICES OF REFRACTION. }
$$

Linck obtained for the dumortierite from Germany

$$
\begin{aligned}
\alpha & =1.678 \\
\beta & =1.686 \\
\gamma & =1.689 \\
\alpha-\gamma & =.011
\end{aligned}
$$

Michel Levy and Lacroix give $(\gamma-\alpha)=.010$ with the dispersion (strong) $\rho^{\prime}>v$, while Bertrand in his original description gives $\rho<v$ as the dispersion. The value $(\gamma-\alpha)$ for quartz is .009 and for andalusite .011. The birefringence for dumortierite is always a little higher than that of the quartz, and in the Washington mineral very nearly that of the andalusite.

PYROGNOSTICS.

The mineral is infusible before the blowpipe, but loses its color, becoming white. It gives a blue color on heating with cobalt nitrate. If the mineral be very finely powdered and intimately mixed with potassium bisulphate and calcium fluoride and the powder be carefully introduced into the flame, a green color, due to the boric acid, may be momentarily seen, but it is an exceedingly difficult reaction to obtain.

\section{CHEMICAI, COMPOSITION.}

In 1881, after the first announcement of the discovery of the mineral had been made by Gonnard, Damour gave the following analysis of the mineral:

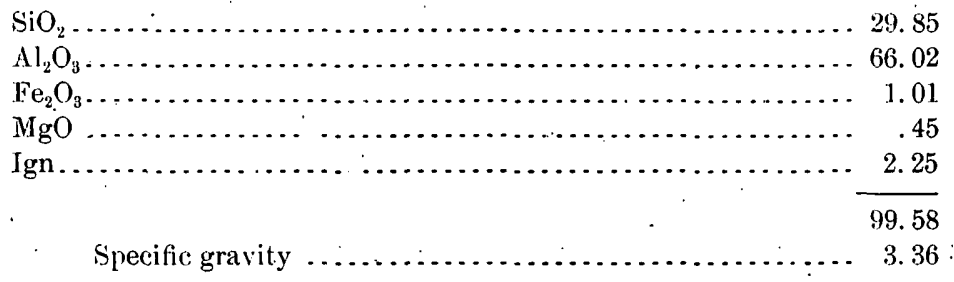

From this analysis the formula $4 \mathrm{Al}_{2} \mathrm{O}_{3}, 3 \mathrm{SiO}_{2}$ was calculated. Damour did not suspect the presence of boric acid in the mineral, and what was weighed as alumina probably contained several per cent

Bull, 262-05-8 
$\mathrm{B}_{2} \mathrm{O}_{3}$. In 1887 Riggs gave an analysis of the New York mineral, in which he found 4 per cent $\mathrm{B}_{2} \mathrm{O}_{3}$. Two years later Whitfield gave several analyses of American dumortierite, all showing the presence of $\mathrm{B}_{2} \mathrm{O}_{3}$. In 1899 Linck gave some observations on the mineral, including an analysis by W. Schimpff, showing a strong test for boric acid. In 1902 Ford gave us three analyses of American dumortierite and also mentioned two new localities. During the winter of 1903-4 the writer made an analysis of the California dumortierite collected by himself during the previous summer. An analysis was also made at the same time of the Washington dumortierite kindly furnished by Mr. Brereton.

Believing that one good analysis is better than several poorer ones for the exact determination of the formula of the mineral, there will be presented an analysis of the California dumortierite made by the writer. From this a formula has been calculated for the mineral, and it will be shown how the other analyses agree with this proposed formula. Before giving the results a few preliminary words will not be out of place.

An analysis of dumortierite is a difficult operation. The small amount of silica makes it difficult to get a good fusion. On preliminary trials on an analysis of the California dumortierite, it was found that what was weighed as silica in the regular course of the analysis contained more or less of the undecomposed mineral. Results of about 30 to 32 per cent were obtained. This is, of course, on the uncorrected silica. It was found that a second fusion of the supposed silica was not only very beneficial, but also necessary. What was then weighed as silica contained but little residue. The handling of so large an amount of alumina is very eumbersome, and an accurate determination of the alumina (plus iron and other oxides here precipitated) is difficult. The boric acid determination is tedious and difficult. The accurate determination of the water, which is given off only at a high temperature, is also not easy. One can thus see that an analysis of such a mineral is a troublesome operation and that a greater allowance must be made than for most silicate analyses.

The specimen analyzed was selected in the field, an exceedingly pure piece weighing about 10 grams being chosen. The specific gravity of this piece was taken by suspension in water, giving 3.306. This was broken into small pieces and carefully examined for muscovite, quartz, or other minerals. Sections of the mineral shiwed that the dumortierite was free from any inclusions. No grains of any titanium mineral abundant in the quartz could be detected. When the mineral was powdered it was treated with heavy solution, of specific gravity 3.10, and a minute amount of mineral (muscovite?) stayed on top and was removed. The separation was repeated several times, and the powder was dried at $100^{\circ}$ and carefully examined under the 
microscope for impurities. None was found. The mineral was unquestionably pure.

The general analytical methods used were those pursued in the Survey laboratory for silicate analyses, with a few modifications. The mineral was fused with sodium carbonate, the silica separated and re-fused with sodium carbonate. The silica was filtered off, weighed, and treated with HF, which left some residue. The alumina (plus iron and titanium) was precipitated three times to be sure of removing all of the sodium salts. It was ignited and weighed with the silica residue, fused with sodium bisulphate, some silica recovered, the iron was reduced and determined by titration and the titanium was determined colorimetrically. The presence of titanium was suspected from the color of the pleochroism of the mineral. The boric acid was determined by the Gooch method, using all of the known precautions. The mineral was twice fused with sodium carbonate and the boric acid was finally weighed as calcium borate. The water was collected in a calcium chloride tube, the mineral being heated in a Gooch tubulated crucible in the usual manner. A blank determination was run before and after each water determination and a small correction applied. All possible precautions were taken throughout the analysis, which was made in duplicate. The results are given below.

\begin{tabular}{|c|c|c|c|}
\hline - & 1. & 2. & Average. \\
\hline $\mathrm{SiO}_{2} \ldots$ & 28.58 & 28.78 & 28.68 \\
\hline $\mathrm{Al}_{2} \mathrm{O}_{3} \ldots \ldots \ldots \ldots \ldots$ & 63.31 & 63.30 & 63.31. \\
\hline 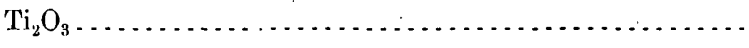 & 1.49 & 1.40 & 1.45 \\
\hline 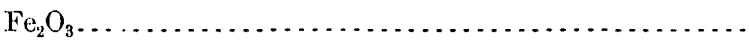 & .21 & .25 & .23 \\
\hline $\mathrm{H}_{2} \mathrm{O} \ldots \ldots \ldots \ldots \ldots \ldots \ldots \ldots$ & 1.53 & 1.51 & 1.52 \\
\hline \multirow[t]{2}{*}{$\mathrm{B}_{2} \mathrm{O}_{3} \ldots \ldots \ldots \ldots \ldots \ldots$} & 5. 21 & 5.53 & 5.37 \\
\hline & 100.33 & 100.77 & 100.56 \\
\hline
\end{tabular}

The titanium is regarded as present as $\mathrm{Ti}_{2} \mathrm{O}_{3}$, replacing the alumina. Combining the alumina, titanium, and iron, the following ratios are obtained:

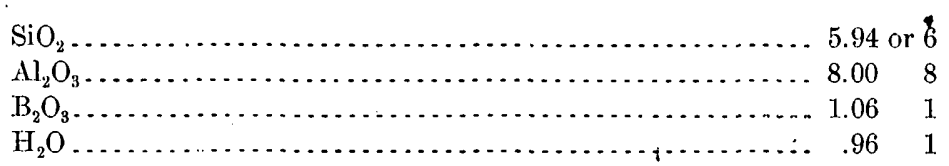

The formula for dumortierite then is

$$
8 \mathrm{Al}_{2} \mathrm{O}_{3}, 1 \mathrm{~B}_{2} \mathrm{O}_{3}, 1 \mathrm{H}_{2} \mathrm{O}, 6 \mathrm{SiO}_{2} \text {. }
$$

It.has not been proved that either boric acid and alumina or boric acid and hydroxyl may mutually replace each other in minerals as fluor- 
ine and hydroxyl are known to do. There is, then, no reason that the writer can see why the alumina, boric acid, and water in dumortierite should not be present in fixed quantities, and that the variations shown in analyses are not due to "isomorphous replacements," but to inaccuracy of analyses or impure material.

Having established the above formula from the analysis, let us see how closely the other analyses conform to it.

The best series of analyses is that made by Ford of mineral from three American localities. His first analyses of the Arizona material are tabulated below.

\begin{tabular}{|c|c|c|c|c|}
\hline & 1. & 2. & 3. & Average. \\
\hline $\mathrm{SiO}_{2}, \ldots \ldots \ldots \ldots \ldots \ldots$ & 30.00 & 29.66 & 29.91 & 29.86 \\
\hline $\mathrm{Al}_{2} \mathrm{O}_{3}$ & 63.20 & 63.74 & 63.76 & 63.56 \\
\hline 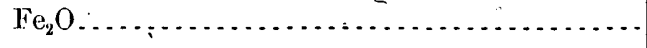 & .23 & .23 & & .23 \\
\hline $\mathrm{B}_{2} \mathrm{O}_{3} \ldots \ldots \ldots \ldots \ldots \ldots$ & 5.47 & 5.06 & & 5. 26 \\
\hline \multirow[t]{2}{*}{$\mathrm{H}_{2} \mathrm{O}$} & 1.45 & 1.38 & & 1. 41 \\
\hline & & & & 100.32 \\
\hline
\end{tabular}

The ratios calculated from the average analysis give

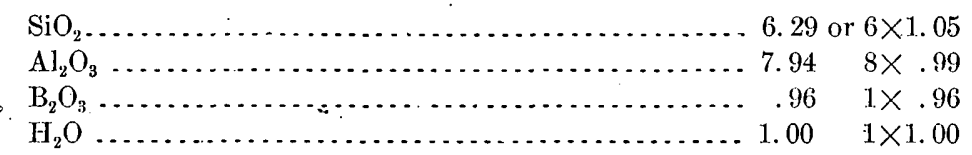

The agreement with the proposed formula is perfect.

His second analysis, that of the California mineral, shows slight variations from the results obtained by the writer. The presence of titanium was not determined. His analysis is:

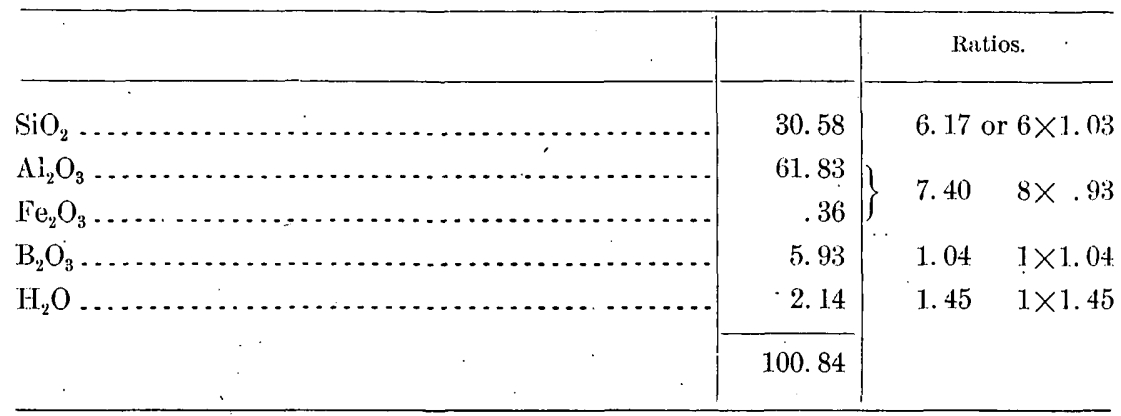

The ratios agree well with the new formula except for the water content. Remembering, however, that the amount of water present is very small and that a difference of 0.10 per cent: would make a large difference in the ratios; that Ford determined his water by igniting the mineral with lime, thus not weighing the water directly; and that the writer obtained only 1.52 per cent on the same mineral from 
the same locality, it seems much preferable to regard the determination of the water in Ford's analysis as too high rather than to attempt an explanation of it by the assumption of "isomorphous replacement, etc."

Of the third analysis by Ford of the New York mineral, he says: "It is fully realized that the results are not to be looked upon as being as exact as those of the other analyses."

His analysis is:

\begin{tabular}{|c|c|c|c|}
\hline . & & \multicolumn{2}{|c|}{ Ratios. } \\
\hline $\mathrm{SiO}_{2} \ldots \ldots \ldots \ldots$ & 31. 24 & \multicolumn{2}{|c|}{6.23 or $6 \times 1.04$} \\
\hline 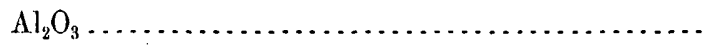 & 61.26 & 7.23 & $8 \times .90$ \\
\hline $\mathrm{Fe}_{2} \mathrm{O}_{3} \ldots \ldots \ldots \ldots \ldots \ldots \ldots$ & .10 & & \\
\hline 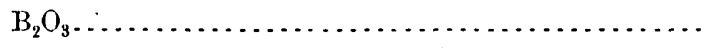 & 6.14 & 1.06 & $1 \times 1.06$ \\
\hline \multirow[t]{2}{*}{ 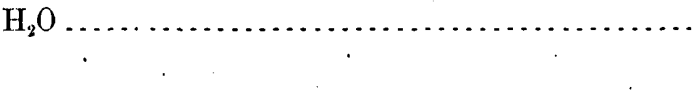 } & 2.09 & 1.40 & $1 \times 1.40$ \\
\hline & 100. 83 & & \\
\hline
\end{tabular}

Assuming that his water content is somewhat high, the ratios agree well with the new formula.

This concludes the list of analyses of dumortierite which were made on pure material and with due knowledge of what was to be determined. A number of other analyses will now be given, which serve in a general way for the determination of the composition of the mineral, but can not be relied on for exact results.

One, which has heretofore not been published, was made by the writer on the Washington dumortierite. About 200 grams of the rock was powdered, and by repeated separation with heavy solutions about 4 grams of dumortierite were obtained. The sample was by no means pure. It was found impossible to remove all the andalusite, an unknown but small amount remaining. It was found during the course of the analysis that the samples also contained some titanite (leucoxene) and a very small amount of pyrite. The analysis was made with all the care possible, and the following results were obtained:

\begin{tabular}{|c|c|c|}
\hline & \multirow[b]{2}{*}{28.51} & $\begin{array}{l}\text { Ratios after deduct- } \\
\text { ing titanite. }\end{array}$ \\
\hline \multirow{2}{*}{ 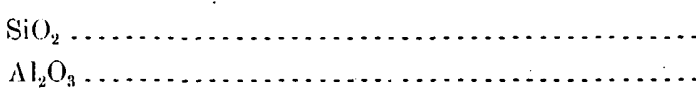 } & & 5.97 or $6 \times 0.99$ \\
\hline & 59.75 & \multirow{2}{*}{$8 \times .97$} \\
\hline 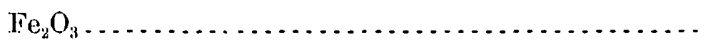 & 2.48 & \\
\hline $\mathrm{TiO}_{2} \ldots \ldots \ldots \ldots \ldots \ldots \ldots$ & .95 & \\
\hline $\mathrm{H}_{2} \mathrm{O} \ldots \ldots \ldots \ldots \ldots \ldots$ & 2.12 & $\begin{array}{l}.1 \times 1.53 \\
1 \times 1.03\end{array}$ \\
\hline 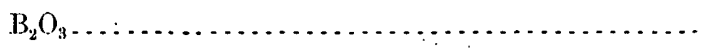 & 5.54 & \multirow{2}{*}{$\begin{array}{l}1.53 \\
1.03\end{array}$} \\
\hline \multirow[t]{2}{*}{ 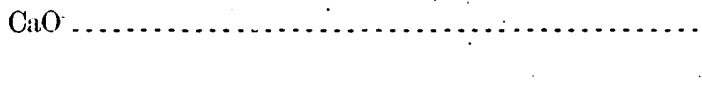 } & .68 & \\
\hline & 100.03 & \\
\hline
\end{tabular}


Excepting for the high-water content the analysis agrees very well with the formula. No allowance was made for the small amount of andalusite present, which would slightly alter the ratios.

The analysis by Schimpff of dumortierite from Germany is given below. Obviously it is worthless for any calculation.

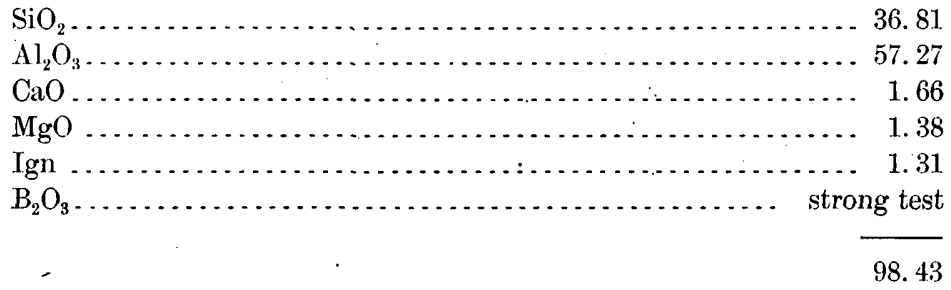

Of similar character is Jannasch's analysis of the Argentine mineral. The sample was probably very impure:

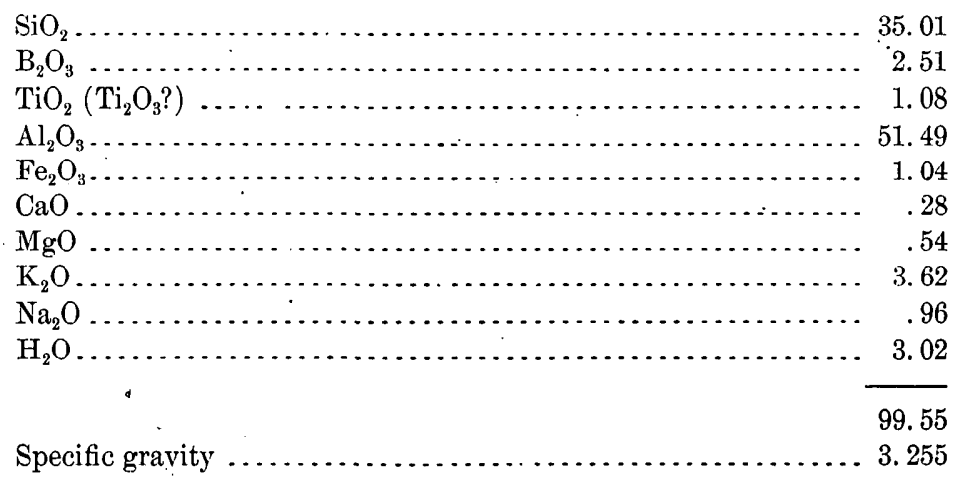

There now remain the analyses of Whitfield and Riggs, of which but one is suitable for any calculation. The analyses are as follows, No. 1 being of the New York mineral, by Riggs; No. 2 of the New York, and Nos. 3 and 4 of the Arizona mineral, by Whitfield.

\begin{tabular}{|c|c|c|c|c|}
\hline . & 1. & 2. & 3. & 4. \\
\hline $\mathrm{SiO}_{2}$. & 34.82 & 31.44 & 31.52 & 27.99 \\
\hline $\mathrm{Al}_{2} \mathrm{O}_{3} \ldots \ldots \ldots \ldots \ldots \ldots \ldots$ & 55.30 & 68.91 & 63.66 & 64.49 \\
\hline MgO $\ldots \ldots \ldots \ldots \ldots \ldots \ldots$ & .57 & 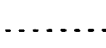 & .52 & trace \\
\hline $\mathrm{K}_{2} \mathrm{O} \ldots \ldots \ldots \ldots \ldots \ldots \ldots \ldots \ldots$ & 1.04 & $\ldots . .$. & .11 & ....... \\
\hline $\mathrm{Na}_{2} \mathrm{O} \ldots \ldots \ldots \ldots \ldots \ldots \ldots$ & 1.76 & & .37 & ….... \\
\hline $\mathrm{P}_{2} \mathrm{O}_{5} \ldots \ldots \ldots \ldots$ & & & & $\cdot .20$ \\
\hline $\mathrm{B}_{2} \mathrm{O}_{3} \ldots \ldots \ldots$ & 4.07 & trace & 2.62 & 4.95 \\
\hline \multirow[t]{2}{*}{ 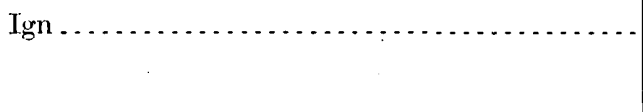 } & 2.96 & . & 1.34 & 1.72 \\
\hline & 100.52 & 100.33 & 100.14 & 99.35 \\
\hline
\end{tabular}


The ratios of the last analyses are

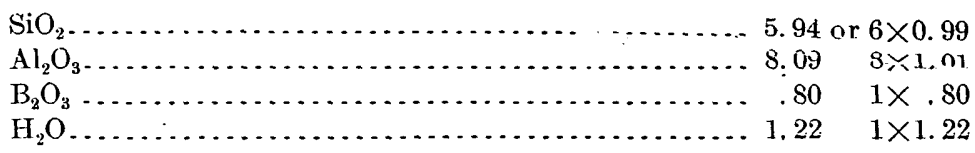

Approximately they agree with the formula.

The only question of which there seems to be any doubt is whether the water should he 1 or $1 \frac{1}{2}$ molecules. As, however, the best analyses show but 1 molecule and their evidence is considered as of much more value than a larger number of inferior analyses, there is no question in the writer's mind but that the formula for dumortierite is

$$
8 \mathrm{Al}_{2} \mathrm{O}_{3}, 1 \mathrm{~B}_{2} \mathrm{O}_{3}, 1 \mathrm{H}_{2} \mathrm{O}, 6 \mathrm{SiO}_{2} \text {. }
$$

This may be written

$$
\left(\mathrm{SiO}_{4}\right)_{3} \mathrm{Al}(\mathrm{AlO})_{7}(\mathrm{BO}) \mathrm{H}
$$

which is the same as the formula given by Groth except that for (BO) he puts $(\mathrm{AlO})$. His formula is $\left(\mathrm{SiO}_{4}\right)_{3} \mathrm{Al}(\mathrm{AlO})_{8} \mathrm{H}$.

This formula may be written in the following form:

$$
\begin{aligned}
\mathrm{SiO}_{4} & \equiv(\mathrm{AlO})_{3} \\
\mathrm{Al}<\mathrm{SiO}_{4} & \equiv(\mathrm{AlO})_{3} \\
\mathrm{SiO}_{4} & =\mathrm{AlO} \\
& \mathrm{BO} \\
& \mathrm{H}
\end{aligned}
$$

This formula is similar to that of andalusite, which is written

$$
\begin{aligned}
& \mathrm{SiO}_{4} \equiv \mathrm{Al} \\
& \mathrm{SiO}_{4} \equiv \mathrm{Al} \\
& \mathrm{SiO}_{4} \equiv(\mathrm{AlO})_{3}
\end{aligned}
$$

Dumortierite alters to muscovite. The change can be very well shown by these formula, and seems to be entirely in accordance with the group of minerals to which it is related.

$$
\begin{aligned}
& \text { Dumortierite. Muscovite. } \\
& \left.\begin{array}{rr}
\mathrm{SlO}_{4} \equiv(\mathrm{AlO})_{3} & \mathrm{SiO}_{4} \equiv \mathrm{Al} \\
-\mathrm{SiO}_{4} \equiv(\mathrm{AlO})_{3}=\mathrm{Al} & <\mathrm{SiO}_{4} \equiv \mathrm{Al} \\
\mathrm{SiO}_{*}-\mathrm{AlO} & \mathrm{SiO}_{4}-\mathrm{K} \\
\searrow \mathrm{HO} & \mathbb{\mathrm { H } _ { 2 }}
\end{array}\right\}+ \text { alumina and boric acid set free. }
\end{aligned}
$$

\section{LITERATURE.}

Bertrand, Émile. Sur un minéral bleu de Chaponost, près Lyon. Büll. Soc. Min., vol. 3,1880 , p. 171.

Gonsard, $\mathrm{F}$. Note sur l'existence d'une espèce minérale nouvelle, la dumortiérite dans le gneiss de Beaunan, audessus des anciens aqueducs galloromains de la vallée de l'Iseron (Rhône). Ibid., vol. 4, 1881, p. 2. 
Damour, A. Analyse de la dumortiérite. Ibid., vol. 4, 1881, p. 6.

Bertrand, Émite. De l'application du microscope à l'étude de la minéralogie. Ibid., vols. 8 and 9,1881 .

RigGs, R. B. Am. Jour. Sci. (3d ser.), vol. 34, 1887, p. 406.

Chamberlain, B. B. Trans. New York Acad. Sciences, vól. 7, 1888, p. 211.

Michel-Lévy, A., and Lacroix, A. Comptes Rendus, pp. 106, 777, and 1546, 1888.

Gonnird, F. Sur un nouveau gisement de dumortiérite ì Brignais (Rhône). Bull. Soc. Min., vol. 11, 1888, p. 64 .

Diller, J. S., and Whitfield, J.. F. Dumortiérite from Harlem, N. Y., and Clip, Ariz. Am. Jour. Sci. (3d ser.), vol. 37, 1889, pp. 216-219. Also Bull. U. S. Geol. Survey, No. 64, 1890, p. 31.

Gonnard, F. Sur un nouveau gisement de dumortiérite dans le Rhône. Bull. Soc. Min., vol. 15, 1892, p. 230.

Romberg, J. Petrographische untersuchungen an argentinischen Graniten. "Neues" Jahrbuch, Beil. Band. 8, 1893, p. 340.

Hovey, E. O. Bull. Am. Mus. Nat. Hist., vol. 7, 1895, pp. 341-342.

Lrnck, G. Die Pegmatite des oberen Veltlin. . Jenaische Zeitschr. f. Naturwiss., vol. 33, 1899, pp. 345-360. Ref.: Zeit. f. Kryst., vol. 35, 1902, p. 319.

RösLer, H. Ueber Hussakit (Xenotim) und andere seltene gesteinbildende Mineralien. Zeit. f. Kryst., vol. 36, 1902, p. 262.

Ford, W. E. On the chemical composition of dumortierite. Am. Jour. Sci. 4th ser., vol. 14, 1902, p. 426. 


\section{MINERALOGICAL NOTES.}

By W. T. Schaller.

\section{HALI,OYSITE.}

The pink clay occurring at Branchville, Conn., has been shown ${ }^{a}$ to be montmorillonite, while that occurring at Norway. Me., has proved ${ }^{b}$ to be cimolite. That from the lepidolite mine near Pala, San Diego County, Cal., differs from both of the New England clays, being comparable with balloysite.

At Pala the halloysite occurs in large seams, often several inches thick, and many feet in length. The clay is somewhat moist, but quickly dries to a crumbling mass when taken out of the mine. In color it is rather deeper pink than the Norway cimolite and occasionally is somewhat translucent. It readily crumbles to a fine powder when placed in water. The material analyzed had been drying in the air for over three months.

The results of analysis are shown below.

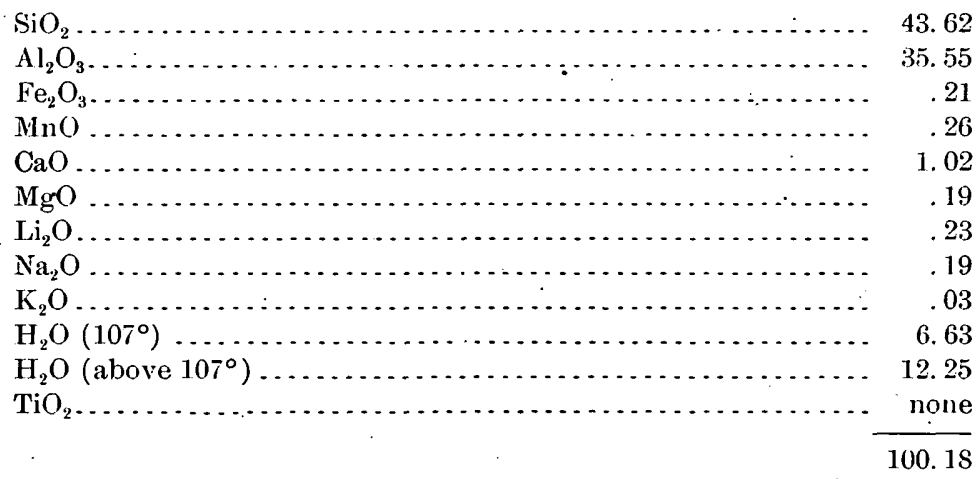

The iron was determined as $\mathrm{Fe}_{2} \mathrm{O}_{3}, \mathrm{FeO}$ not being tested for: The analysis agrees well with the formula

$$
\mathrm{H}_{4} \mathrm{Al}_{2} \mathrm{Si}_{2} \mathrm{O}_{9}+\mathrm{H}_{2} \mathrm{O} \text {. }
$$




\section{AMBLYGONITE.}

The occurrence of amblygonite at the lepidolite mine at Pala, Cal., has already been noticed, and a somewhat fuller description of the mineral is here given. A large deposit has been uncovered, and the indications seem to show that it is merely a small part of an extensive body of massive amblygonite. The mineral usually occurs pure; very rarely small amounts of lepidolite are present with it. Frequently broad cleavage faces with irregular outlines can be seen. The color is white and in thin pieces the mineral is translucent. It fuses easily, coloring the flame red, and in powder is difficultly decomposed by sulphuric acid.

An analysis of a specimen kindly presented by Mr. G. F. Kunz gave the writer the following results:

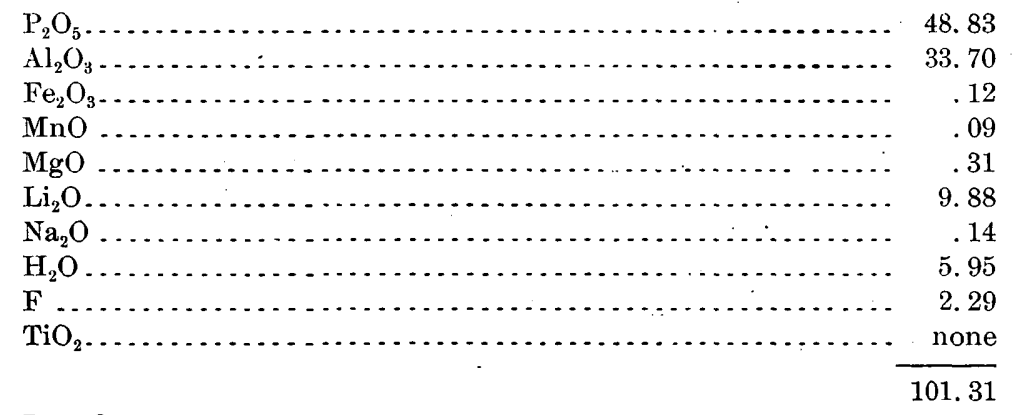

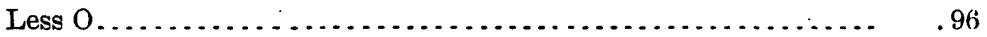

100. 35

Regarding fluorine and hydroxyl as isomorphous, in the specimen analyzed the latter greatly predominates over the fluorine. The water was determined by igniting the mineral with lead oxide, previously heated nearly to fusion. Three determinations gave the loss of weight, due to the escape of water, as $5.89,6.01,5.95$ per cent. The loss of the mineral on ignition was 8.03 per cent, equaling the sum of the water and fluorine content.

\section{BOOTHITE.}

A specimen of a pale-blue copper sulphate was collected at the copper mine near Campo Seco, Calaveras County, Cal., by Mr. James Wise and kindly presented to the writer for investigation. The paleblue color suggested that the mineral might be boothite instead of the more frequently occurring chalcanthite. The results of a chemical analysis have shown that the mineral is boothite, thus affording a second locality for this interesting mineral. Careful quantitative determinations of hydrous copper sulphates will probably show that the heptahydrate is not so rare as may be supposed. 
The mineral from Campo Seco occurs massive, showing no crystalline structure. The average of several determinations afforded the results shown below.

\begin{tabular}{|c|c|c|}
\hline . & & Rutio. \\
\hline $\mathrm{CnO} \ldots \ldots \ldots \ldots$ & 26.13 & 1.00 \\
\hline 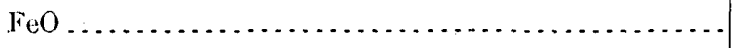 & . 81 & .03 \\
\hline $\mathrm{MgO}, \ldots \ldots \ldots \ldots \ldots \ldots \ldots \ldots \ldots \ldots$ & .64 & $: 05$ \\
\hline 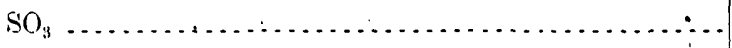 & 27.25 & 1.04 \\
\hline 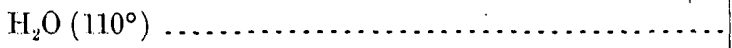 & 36.76 & $6.22) z 06$ \\
\hline 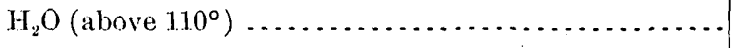 & $4.91\}^{\text {tw. }}$ & $.84\}^{1000}$ \\
\hline \multirow[t]{2}{*}{ 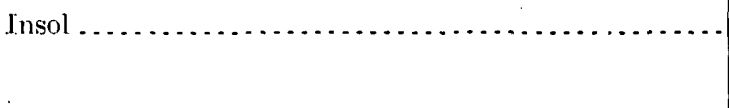 } & 3.96 & (n............ \\
\hline & 100.46 & \\
\hline
\end{tabular}

Formula, $\mathrm{CuSO}_{4} \cdot \mathrm{H}_{2} \mathrm{O}+6 \mathrm{H}_{2} \mathrm{O}$.

A careful determination of the specific gravity of the mineral gave $\left(21^{\circ}\right.$ C.) 1.944 . 'This being much lower than the value obtained (2.1) on the boothite from Leona Heights, a redetermination of the latter was made on purer material collected since the publication of the first results. " This gave as an average value the figure $\left(22^{\circ}\right.$ C.) 1.935. The average of these two determinations, or 1.94 , is probably very near the true value for the specific gravity of boothite.

\section{PISANITE.}

A small specimen of massive pisanite from Gonzales, Monterey County, Cal., was analyzad some time ago and the results are here presented. The quantity of material available for analysis was very small and the determinations do not claim any great accuracy. About 6 per cent of insoluble matter has been deducted and the results recalculated to 100 per cent.

\begin{tabular}{|c|c|c|}
\hline & & Ratio. \\
\hline \multirow{2}{*}{$\mathrm{CnO}$} & 7.56 & 0.27 \\
\hline & 15.85 & $.72\}^{0.89}$ \\
\hline \multirow{3}{*}{ 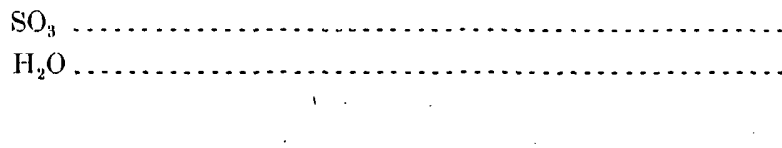 } & 30.74 & 1.08 \\
\hline & .45 .85 & 7. 18 \\
\hline & 100.00 & \\
\hline
\end{tabular}

The analysis approximates to the formula $\mathrm{CuO} .2 \mathrm{FeO}_{\mathrm{e}} 3 \mathrm{SO}_{3} \cdot 21 \mathrm{H}_{2} \mathrm{O}$.

a Schaller, W. T.., Minerals from Leona Heights, Alameda County, Cal.: Bull. Dept. Geol.' Univ. Cal., vol. 3, No. 7. 
In the following table all available analyses of pisanite are tabulated, and one can readily see that there is no definite ratio between the copper andiron. The formula is then written $(\mathrm{Cu}, \mathrm{Fe}) \mathrm{SO}_{4} \cdot 7 \mathrm{H}_{2} \mathrm{O}$, pisanite being an isomorphous mixture of melanterite and boothite. All the analyses are calculated to 100 per cent. ${ }^{a}$

\begin{tabular}{|c|c|c|c|c|c|c|}
\hline & No. 1. & No. 2. & No. 3. & No. 4. & No. 5. & No. 6. \\
\hline $\mathrm{CuO}$ & & 7.56 & 9.17 & 10.07 & 12.61 & 15.52 \\
\hline $\mathrm{FeO} .$. & 25.86 & 15.85 & 16.37 & $(16.15)$ & 1.4. 14 & 12.14 \\
\hline $\mathrm{SO}_{3} \ldots \ldots \ldots \ldots$ & 28.80 & \multirow{2}{*}{$\begin{array}{l}30.74 \\
45.85\end{array}$} & 29.00 & 28.84 & 28.44 & 27.82 \\
\hline \multirow[t]{2}{*}{$\mathrm{H}_{2} \mathrm{O} \ldots \ldots \ldots \ldots \ldots \ldots \ldots$} & 45.34 & & 45.46 & $(44.94)$ & 44.81 & 44.52 \\
\hline & 100.00 & 100.00 . & 100.00 & 100.00 & 100.00 & 100.00 \\
\hline & No. 7. & \multicolumn{2}{|c|}{ No. 8.} & No. 9. & No. 10. & No. 11. \\
\hline $\mathrm{CuO}$. & 15.56 & \multicolumn{2}{|c|}{17.45} & 17.64 & 18. 81 & 27.85 \\
\hline $\mathrm{FeO}$. & 1.0. 98 & \multicolumn{2}{|c|}{10.18} & 9.62 & 8.51 & $\therefore .$. \\
\hline $\mathrm{SO}_{3}$. & 29.90 & \multicolumn{2}{|c|}{28.43} & 28.27 & 27.93 & 28.02 \\
\hline \multirow[t]{2}{*}{$\mathrm{H}_{2} \mathrm{O} \ldots \ldots \ldots \ldots \ldots$} & 43.56 & \multicolumn{2}{|c|}{43.94} & 44.47 & 44.75 & 44.13 \\
\hline & 100.00 & \multicolumn{2}{|c|}{100.00} & 100.00 & 100.00 & 100.00 \\
\hline
\end{tabular}

\section{GYROLITE.}

In the same rock and but about 50 feet distant from the place where the pectolite ${ }^{b}$ and datolite occur, at Fort Point, San Francisco, Cal., were a number of veins of a pearly massive zeolite, which analysis showed to be gyrolite. The veins, ranging from microscopic size to a thickness of nearly a centimeter, occur in a dark' basic igneous rock, probably a basalt. The gyrolite has replaced the rock and grown outward from both sides of the vein, forming a contact line in the middle where the two parts join. The mineral is grouped in spherical and also in massive platy or plumose aggregates. It is at times associated with apophyllite, but usually occur's pure. Its color on the fresh fracture is white, while on the weathered surface it is a brownishyellow. It has a decided pearly luster and possesses a good cleavage.

Under the microscope, a thin section of the rock containing these veins shows that the rock has been replaced by this secondary mineral, always commencing as a minute vein, probảbly originating in a micro-

a Anal. No:1, theoretical comp. of melanterite, $\mathrm{FeSO}_{4} \cdot 7 \mathrm{H}_{2} \mathrm{O}$. No. 2, Schaller, anal. quoted above; No. 3, Schaller, Bull. Dept. Geol. Univ. of Cal., vol. 3, No. 7: No. 4, Hintz, Zeit. Krys., 2, 309; 'No. 5, Hillebrand, Bull. U. S. Geol. Survey No. 220, p. 105; No. 6, see No. 3; No. 7, Pisani, Comptes Rendus, 1859, 48. 807; No. 8, see No. 3; Nos. 9 and 10, Herz, Zeit. Krys., 26, 16; No. 11, theoretical comp. of boothite, $\mathrm{CuSO}_{4} .7 \mathrm{H}_{2} \mathrm{O}$.

$b$ Eakle, A. S., Mineralogical notes: Bull. Dept. Geol. Uviv. Cal., vol. 2, No. 10, 1901. 
scopic fissure of the rock. A multitude of these veins are present, lying in nearly parallel position and varying greatly in size. There is nothing to suggest that the gyrolite may have been derived from apophyllitè. It may have been derived entirely from the igneous rock or: only in part. The mineral was first deposited at the walls of the vein and from thence grew outward into the open fissure from both sides, also probably replacing the rock wall. The thin section, as well as the hand specimen, shows a decided plumose structure of the mineral. These plumose aggregates show, under crossed nicols, the black extinction cross. The interference colors are bright and vivid. Heddle ${ }^{i}$ says of these: "The sections of orbicular gyrolite are among the most splendid of polariscopic objects, resembling a circularly. opened fan, of most brilliant and abruptly contrasted colors."

The properties of the mineral are not very well known. Heddle ${ }^{b}$ mentions some crystals resembling heulandite in form. The mineral is described as unaxial, though as a matter of fact it is biaxial, but like biotite the axial angle becomes $0^{\circ}$ at times. Cleavage plates show the emergence of a bisectrix. The (approximate) measurement of $2 \mathrm{E}_{\mathrm{N} a}$ gave values (on the Fort Point material) of from $0^{\circ}$ to $25^{\circ}$. The sign is always negative. Heddle obtained $2 \mathrm{E}=0^{\circ}-3^{\circ}$. When there was a straight edge suggesting a possible crystal direction, the extinction was not parallel.

Dana $^{c}$ gives as the formula of the mineral $3 \mathrm{H}_{2} \mathrm{O}, 2 \mathrm{CaO}, 3 \mathrm{SiO}_{2}$, while Clarke ${ }^{d}$ gives $5 \mathrm{H}_{2} \mathrm{O}, 4 \mathrm{CaO}, 6 \mathrm{SiO}_{2}$, which is the formula deduced by the writer from the following analysis of the San Francisco mineral:

\begin{tabular}{|c|c|c|}
\hline & & Ratio. \\
\hline 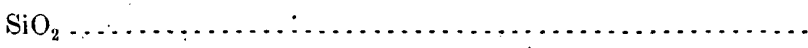 & 53.47 & 6.02 \\
\hline 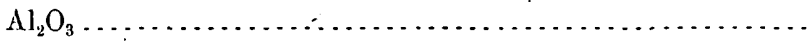 & $\cdot \quad .22$ & \\
\hline 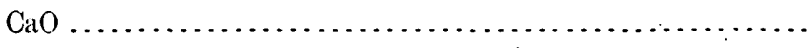 & 32.00 & 409 \\
\hline 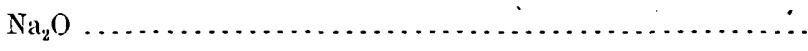 & 1. 25 & 4.02 \\
\hline \multirow[t]{2}{*}{ 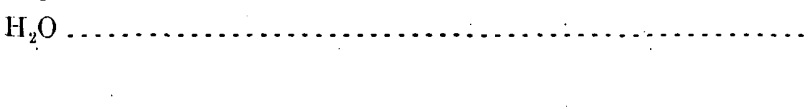 } & 13.21 & 4.99 \\
\hline & 100.15 & \\
\hline
\end{tabular}

The specific gravity is 2.39. Traces of iron, magnesium, and potassium are present, while strontium, chlorine, and fluorine are absent.

" Heddle, M. F., On the optic properties of gyrolite: Min. Mag., vol. 9, 1890-1891, p. 391.

b Heddle, M. F., On the crystalline form of gyrolite: Min. Mag., vol. 8, 1888-1889, p. 272.

c System of Mineralogy, 6th edition, p. 566, 1892.

$a$ Clarke, F. W., The constitution of the silicates: Bul], U. S. Geol. Survey No. 125, 1895, p. 81, 
The mineral is easily decomposed by hydrochloric acid. - Certain analogies can be noted between heulandite and gyrolite, and from this and the properties of the mineral, as far as known, the writer believes gyrolite to be monoclinic. Heddle says in connection with some plane angles he measured on gyrolite from Scotland: "The above, as far as it goes, seems to show gyrolite to be oblique, and near heulandite in form."

The formulæ of the two minerals are also similar.

Gyrolite............................ $6 \mathrm{SiO}_{2} \cdot 4 \mathrm{CaO} . \quad 5 \mathrm{H}_{2} \mathrm{O}$.

Heulandite $\ldots \ldots \ldots \ldots \ldots \ldots \ldots \ldots \mathrm{SiO}_{2} . \mathrm{Al}_{2} \mathrm{O}_{3} . \quad \mathrm{CaO} .5 \mathrm{H}_{2} \mathrm{O}$.

\section{APOPHYLIITE.}

With the gyrolite were found a number of specimens of clear, transparent, but very minute crystals of apopbyllite. These are usually less than $1 \mathrm{~mm}$. thick and show only the base, prism of the second order, and the unit pyramid of the first order. Some years ago a specimen was obtained here on which the apophyllite crystals have been changed to quartz. As they proved to be infusible, a more extended investigation of them was made.

The crystals, from 1 to $3 \mathrm{~mm}$. in diameter, appear cubic, with the corners truncated by small faces. Measurements of the best crystals showed that they are tetragonal and that they agree in angles with those of apophyllite. The prism faces are vertically striated and faces of the other two forms are also rarely somewhat striated.

By trial it was found that hydrochloric acid does not attack the crystals, so that the associated calcite was easily removed and pure material for analysis was obtained. The crystals are opaque, and no optical determinations could be made.

The analysis gave the following figures, showing that the crystals are now, chemically, essentially silica with various impurities:

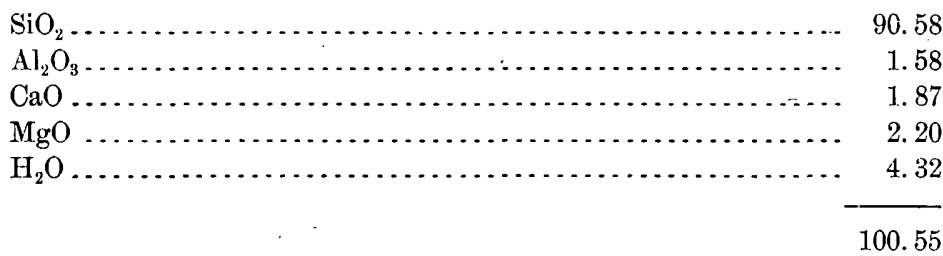

7. TELLURITE.

100.55

Several small crystals of tellurite were referred to the writer by Doctor Hillebrand. Their locality is the W. P. H. mine, Cripple Creek, Colo. The crystals are transparent yellow and reach a length of about $2 \mathrm{~mm}$. They are thin tabular parallel to the brachypinacoid. This form is normal to a bisectrix, and the axial plane is parallel to $a(100)$. 
The crystals show numerous vicinal faces, which are here not given. The forms which were established are ${ }^{b}$

$$
\zeta=\{010\}, r=\{120\}, * h=\{520\}, * l=\{210\}, p=\{111\} .
$$

The angles measured are:

\begin{tabular}{|c|c|c|c|c|c|}
\hline & \multicolumn{2}{|c|}{ Mensured. } & \multicolumn{3}{|c|}{ Calculated. } \\
\hline & $\phi$ & $\rho$. & $\phi$. & $\rho$. & \\
\hline$b=010 \ldots \ldots$ & $\begin{array}{ll}\circ & 1 \\
0 & 00\end{array}$ & $\begin{array}{cc}\circ & \\
90 & 0\end{array}$ & $\begin{array}{ll}\circ & , \\
0 & 0\end{array}$ & $\begin{array}{c}\circ \\
90\end{array}$ & .' \\
\hline$r=120 \ldots \ldots \ldots$ & $47 \quad 34$ & $90 \quad 0 \mathrm{C}$ & $47 \quad 3$ & 90 & 00 \\
\hline$h=520 \ldots \ldots \ldots \ldots$ & $79 \quad 30$ & $90 \quad 0$ & 793 & 90 & 00 \\
\hline$l=210 \ldots \ldots \ldots \ldots$ & $77 \quad 17$ & $90 \quad 0$ & $77 \quad 0$ & 90 & 00 \\
\hline$\eta=111 \ldots \ldots \ldots \ldots \ldots \ldots \ldots$ & $65 \quad 47$ & $48 \quad 1$ & $65 \quad 2$ & 48 & 16 \\
\hline
\end{tabular}

The two new forms, $h$ and $l$, gave the following measurements:

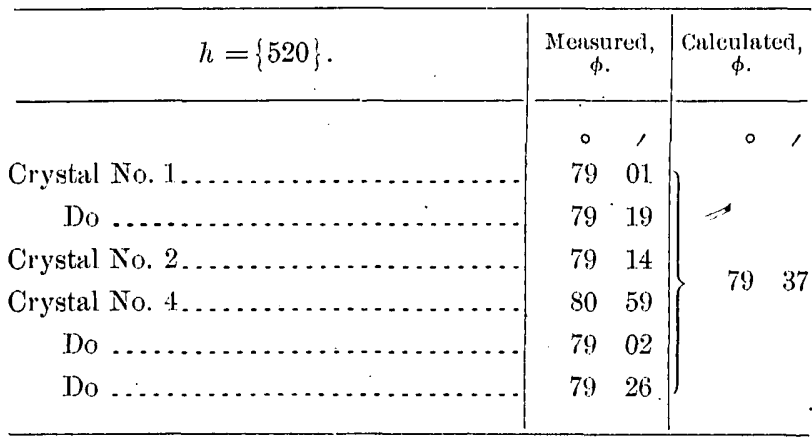

On crystals Nos.1 and 4 the faces are very nar. row, while on crystal No. 2 they are much broader. The reflections were fairly good.

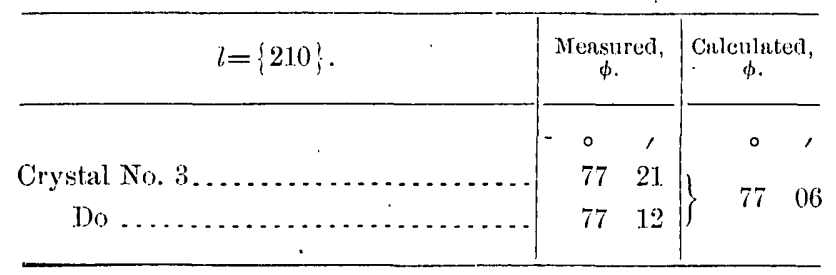

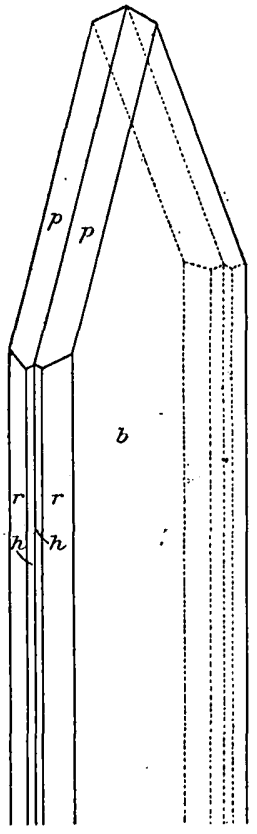

FIG. 9.-Tellurite.

The fices were both narrow and the reflections were rather poor.

It seems to the writer that the axial ratio as given by Dana should be preferred to that of Goldschmidt, who doubles both the $a$ and $c$ axes. This wonld make the (only) terminal form the unit pyramid, 
while the forms in the prism zone have as simple indices in one case as in another, as can be seen from the following table.

\begin{tabular}{|c|c|c|c|c|c|}
\hline & Dana. & $\begin{array}{c}\text { Gold- } \\
\text { schmidt. }\end{array}$ & & Dana. & $\begin{array}{l}\text { Gold- } \\
\text { schmidt. }\end{array}$ \\
\hline$b \ldots \ldots \ldots$ & 010 & 010 & $h \ldots \ldots$ & 520 & 510 \\
\hline$m \ldots . . . .$. & 110 & 210 & $l \ldots$ & 210 & 410 \\
\hline$r \ldots \ldots \ldots \ldots$ & 120 & 110 & $11 \ldots \ldots \ldots$ & 111 & 212 \\
\hline$s \quad \ldots \ldots \ldots \ldots \ldots \ldots$ & 140 & 1.20 & & & \\
\hline
\end{tabular}

\section{S. PREHNITE.}

A mineral from Lower California, sent by G. F. Kunz for determination, proved to be prehnite: The analysis gave the following results:

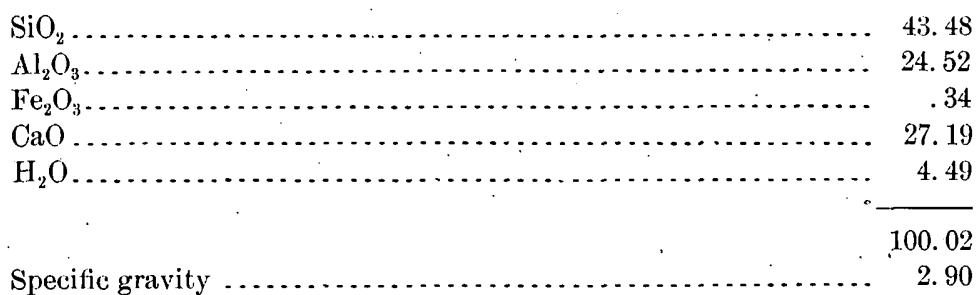

\section{HORNBLENDE.}

Coating the walls and projecting into the amygdaloidal cavities of a lava from Mono County, Cal., were noted small crystals of hornblende, tridymite, and biotite. The locality of the rock, which was kindly furnished by Mr. Maynard Bixby, of Salt Lake City, is given as 8 miles west of Bridgeport, Mono County, Cal. The hornblende and tridymite occur. in sharp crystals, of which a few were measured.

Biotite occurs abundantly as small hexagonal plates, which, under the microscope, show at times a zonal banding in color, the darker being on the outside. The axial angle is very small-at times uniaxial.

The hornblende occur's as long prismatic crystals, becoming extremely acicular and hairlike at times. It is often grouped in radiating bunches and again occurs in single prisms. Their maximum thickness is about one-balf millimeter, and in length they reach not over $5 \mathrm{~mm}$. Under the microscope the pleochroism is in shades of brown. The maximum extinction was $15^{\circ}$. 
Two terminated crystals of measurable size showed the following forms: $\quad c=\{001\}, \quad b=\{010\}, \quad a=\{100\}, m=\{110\}, \quad t=\{\overline{2} 01\}, \quad z=\{021\}$, $i=\{\overline{1} 31\}$.

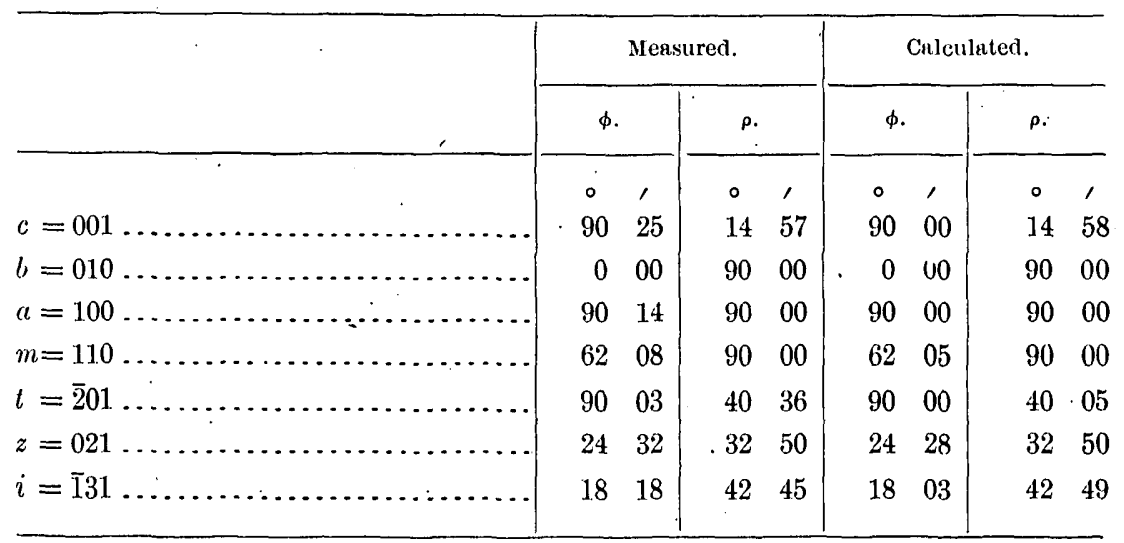

Crystal No. 1 shows: $a, b, c, m, t, z, i$.

Crystal No. 2 shows: $a, b,-, m,-, z-$.

\section{TRIDYMITE.}

Small hexagonal plates of tridymite, $1 \mathrm{~mm}$. in diameter and rarely larger, are rather plentiful in places. The forms present on two crystals which were partially measured are $c=\{0001\}, m=\{10 \overline{1} 0\}$, $i=\{32 \overline{5} 0\}, l=\{54 \overline{9} 0\}, r=\{30 \overline{3} 4\{, f=\{10 \overline{1} 2\}$. The first crystal measured was a twin.

\begin{tabular}{|c|c|c|}
\hline . & Measured. & Calculated. \\
\hline - & & $\circ$ \\
\hline$c \wedge \underline{e} \ldots$ & 35 & $35 \quad 18$ \\
\hline$c_{\wedge} m \ldots \ldots \ldots \ldots \ldots$. & $90 \quad 02$ & 9000 \\
\hline$m_{\wedge} i \ldots \ldots \ldots \ldots \ldots$ & 23 & 2325 \\
\hline$m_{\wedge}, l \ldots \ldots, \ldots \ldots \ldots \ldots \ldots, \ldots$ & $26 \quad 39$ & 2620 \\
\hline 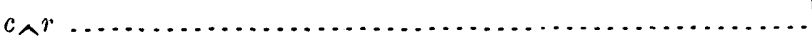 & 54 & $55 \quad 03$ \\
\hline 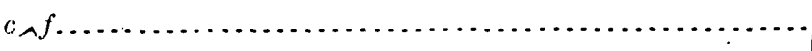 & 43.54 & $43 \quad 39$ \\
\hline
\end{tabular}

\section{ZINNWAIDITE.}

The occurrence of this lithia mica has already been mentioned by Collier, ${ }^{a}$ who has very kindly furnished the writer the numerous samples collected. He gives as the exact locality: On Cassiterite Creek (extension or branch of Lost River), 5 miles from the coast and 8 miles

a Collier, A. J., The tin deposits of the York region, Alaska: Bull. U. S. Geol. Survey No. 229, p. 20. Bull. 262-05-9 
east of Cape York, Alaska. It is stated to occur in a vein cutting through limestone. The bowlders showing the zinnwaldite are float, and in some of these there is a vein, about a centimeter thick, consisting almost entirely of zinnwaldite. Others show the zinnwaldite scattered through massive quartz. Cassiterite is associated with both modes of occurrence. As further associations Collier mentions fluorite, feldspar, calcite, tourmaline, topaz, pyrite, garnet, galena, wolframite, and malachite.

The zinnwaldite has a brown color, and occurs massive without any crystal boundaries. It fuses easily to a black mass, coloring the flame crimson. An incomplete quantitative analysis showed that the mineral is undoubtedly zinnwaldite. The small dikes before mentioned are bordered on one side by a rim of blackish green mica. This rim is about $1 \mathrm{~mm}$. wide and is well developed only on one side of the dike, though it is present on the other side in smaller amount. Under the microscope the rim has a green and brown color and is uniaxial nearest the limestone, but the axial angle increases as the zinnwaldite is approached. In many places the two micas are intergrown. The difference in color from the green to the almost colorless zinnwaldite is very marked. The green mica is probably biotite, possibly somewhat altered to chlorite. Further description of the zinnwaldite is deferred for a later paper. Of the associated minerals, cassiterite and topaz occur in small crystals, a brief description of which follows. The association of cassiterite, topaz, and zinnwaldite is also noteworthy.

\section{CASSITERITE.}

The crystals of cassiterite vary in size, ranging from a thickness of less than $1 \mathrm{~mm}$. to several $\mathrm{cm}$. The large ones are opaque and black; the smaller ones are usually transparent and light brown in color, becoming nearly colorless at times. Twins are very common.

The large crystals usually show the simple combination of $a=\{100\}$, $m=\{110\}, e=\{011\}, s=\{111\}$, while the smaller ones usually are more complex. Two such small ones were measured, the first one a simple crystal, the second a twin. The forms noted are: $a=\{100\}, m=\{110\}$, $k=\{340\}, B=\{550\} ?, r=\{230\}, h=\{120\}, e=\{011\}, s=\{111\}, f=\{231\}$, and the new prism $l=\{140\}$. 
The following are the measured angles:

\begin{tabular}{|c|c|c|c|c|c|c|c|c|}
\hline & \multicolumn{4}{|c|}{ Measured. } & \multicolumn{4}{|c|}{ Calculated. } \\
\hline & $\phi$ & & $\rho$ & & & & р. & \\
\hline & & & & ' & & & & \\
\hline$a=100$ & 0 & 00 & 90 & 00 & 0 & 00 & 90 & 00 \\
\hline$m=110$ & 45 & 00 & 90 & 00 & 45 & 00 & 90 & 00 \\
\hline$k=340$ & 36 & 35 & 90 & 00 & 36 & 52 & 90 & 00 \\
\hline$B=570 \ldots \ldots \ldots \ldots \ldots \ldots \ldots \ldots \ldots \ldots \ldots \ldots \ldots \ldots \ldots \ldots$ & 35 & 48 & 90 & 00 & 35 & 32 & 90 & 00 \\
\hline$r=230 \ldots$ & 33 & 37 & 90 & 00 & 33 & 41 & 90 & 00 \\
\hline$h=120$ & 26 & 30 & 90 & 00 & 26 & 34 & 90 & 00 \\
\hline 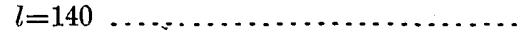 & 13 & 56 & 90 & 00 & 14 & 02 & 90 & 00 \\
\hline$e=011$ & 0 & 03 & 33 & 48 & 0 & 00 & 33 & 54 \\
\hline$s=111 \ldots$ & 45 & 01 & 43 & 35 & 45 & 00 & 43 & 33 \\
\hline$f=231 \quad \ldots$ & 33 & 46 & 67 & 39 & 33 & 41 & 67 & 35 \\
\hline
\end{tabular}

The prism $l=\{140\}$ was noted three times as a narrow face, measurements of which gave the following values for the $\phi$ angle:

$\begin{array}{cc}\circ & \text { ' } \\ 13 & 49 \\ 13 & 19 \\ 14 & 40\end{array}$

The dominant terminal form is $\{111\}$, though $\{011\}$ becomes at times fairly large. $\{231\}$ occurs on crystal No. 1 as minute faces and also as long, narrow line faces.

\section{TOPAZ.}

Two small crystals, about $2 \mathrm{~mm}$. long, which were measured, showed the following forms: ${ }^{a} b=\{010\}, m=\{110\}, l=\{120\}, \pi=\{250\}, g=\{130\}$, $y=\{021\}, f=\{011\}, u=\{112\}, s=\{335\} ; o=\{111\}$. The crystals were rounded and broken and gave, on the whole, rather poor signals. The measurements serve, however, to determine the forms.

\begin{tabular}{|c|c|c|c|c|c|c|c|c|}
\hline , & \multicolumn{4}{|c|}{ Measured. } & \multicolumn{4}{|c|}{ Calculated. } \\
\hline & & & p & & 4 & & $\rho$. & \\
\hline & & & & & & & $\circ$ & \\
\hline$b=010 \quad$. & & & & 00 & 0 & 00 & 90 & 00 \\
\hline$m=110$ & 6. & 59 & 90 & $O C$ & 62 & 08 & 90 & 00 \\
\hline$l=120$ & 4 & 28 & 90 & 00 & 43 & 25 & 90 & 00 \\
\hline$\pi=250$ & 37 & 00 & 90 & 00 & 37 & 07 & 90 & 00 \\
\hline$g=1.30$ & 32 & 26 & 90 & 00 & 32 & 14 & 90 & 00 \\
\hline$y=021$ & c & 38 & 61 & 44 & 0 & 00 & 62 & 20 \\
\hline$f=011$ & ( & 38 & 44 & 24 & 0 & 00 & 43 & 39 \\
\hline$u=1.12$ & 61 & 56 & 45 & 38 & 62 & 08 & 45 & 35 \\
\hline$s=335$ & 6 & 42 & 50 & 31 & 62 & 08 & 50 & 46 \\
\hline$o=111, \ldots \ldots \ldots \ldots \ldots$ & 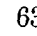 & 10 & 63 & 00 & 62 & 08 & 63 & 54 \\
\hline
\end{tabular}

The only terminal form on crystal No. 1 is $u=\{112\}$. 


\section{BOURNONITE.}

An analysis of massive bournonite from Bogg's mine, Big Bug district, Yavapai County, Ariz:, furnished for analysis by Prof. C. Palache, yielded the figures given below.

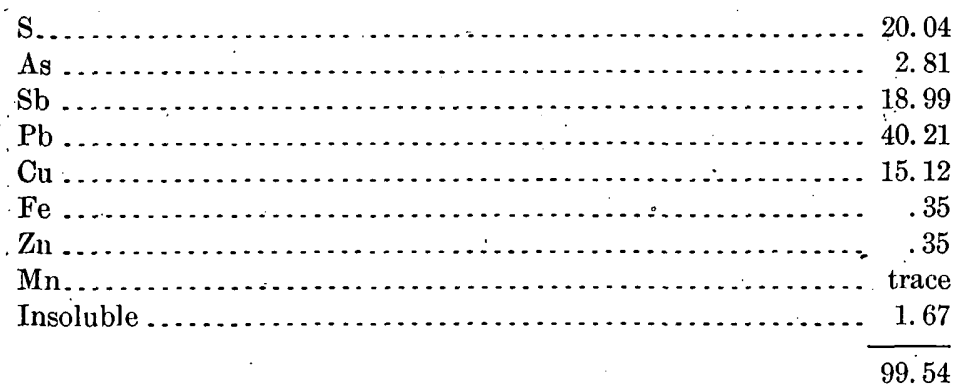

\section{ANHYDRITE.}

A deposit of crystallized anhydrite occurs in Texas, the exact locality of which is not known. The crystals are small, reaching a maximum of $1 \mathrm{~mm}$. in length, and are tabular parallel to the macropinacoid.

The base is present as a long, narrow face.

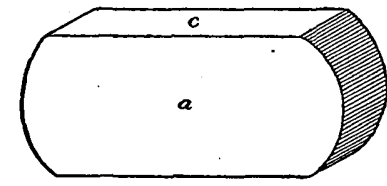

FIg. 10.-Anhydrite.

The clinopinacoid is probably present, but the zone of brachydomes is very rounded. and striated, no sharp faces occurring in this zone. Under the microscope the crystals show that the axial plane is parallel to $b=\{010\}$ and the acute bisectrix is normal to $a=\{100\}$. The interference figure is about as large as that of muscovite and is positive. An analysis was made of the mineral, to leave no doubt as to its identity.

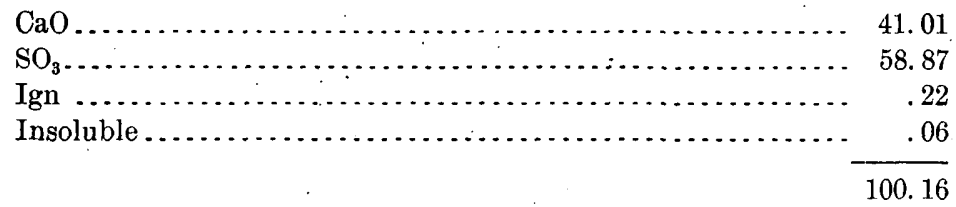

16. GLAUCODOT.

A sample of cobalt ore from the Standard Consolidated gold mine, Sumpter, Oreg., consists of glaucodot, with pyrite and perhaps other sulphides, in a dark silicate rock. Imperfect crystals are abundant, though they usually show but one or two faces. Much of the ore is massive, and it is practically impossible to determine whether it is all glaucodot or in part cobaltite. One crystal was measured. The small crystal (about $1 \mathrm{~mm}$. long) is orthorhombic, and shows the following forms: $m=\{110\}, b=\{010\}, e=\{101\}$, and a very much striated brachydome zone in which the following forms are probably present: $\{014\},\{013\},\{012\}$. 
The following are the angles obtained:

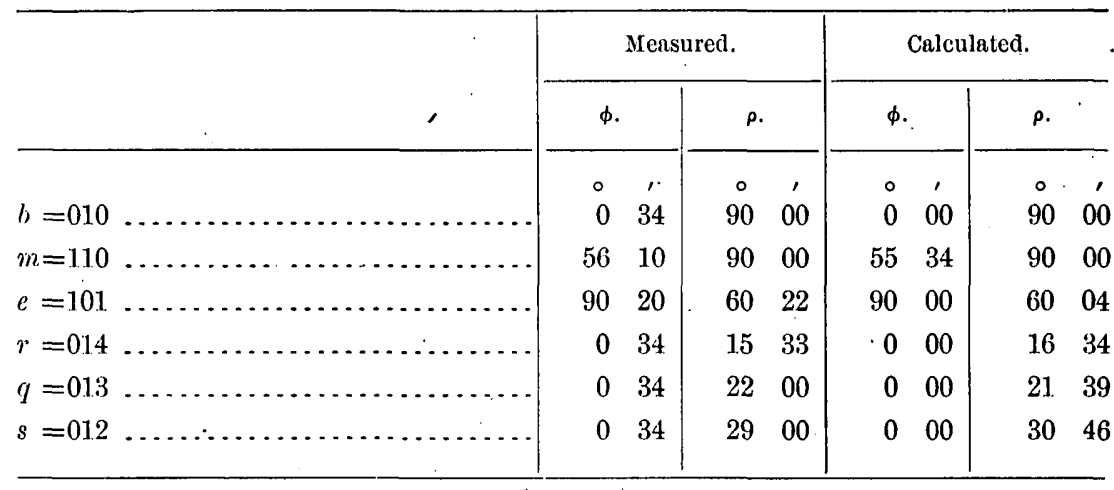

Many other signals between these were seen in the striated brachydome zone, but they probably belong to no definite face.

The analysis gave the following results:

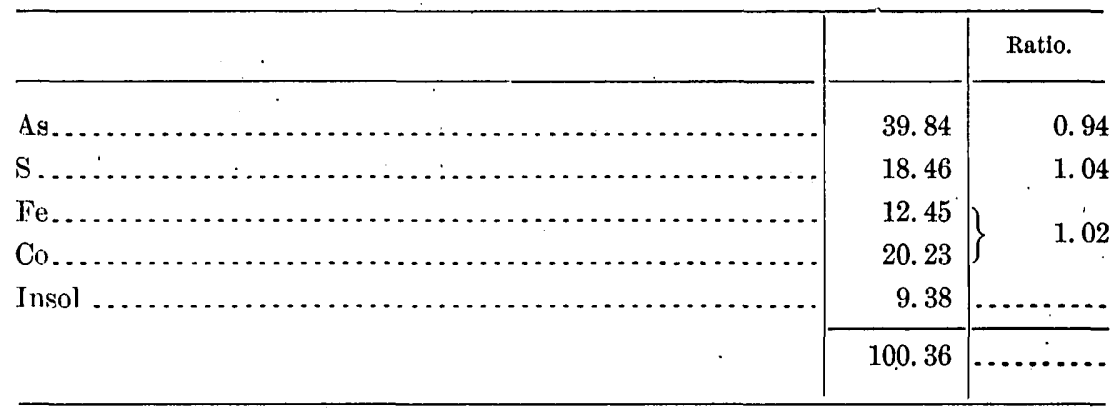

Nickel and antimony were not determined, though they were shown not to be present in any quantity. The ratio of the cobalt to iron is $31: 20$ or $3: 2$, so that the formula may be written

instead of

$$
\mathrm{Co}_{3} \mathrm{Fe}_{2} \mathrm{As}_{5} \mathrm{~S}_{5} \text {, }
$$

$$
\mathrm{R} \text { As } \mathrm{S}, \mathrm{R}=(\mathrm{Co}, \mathrm{Fe}) \text {. }
$$

\section{PYRITE.}

A small group of pyrite crystals from Spanish Peaks, Colo., kindly presented to the writer by Mr. R. Sargent, showed, on examination, a rich combination of forms,

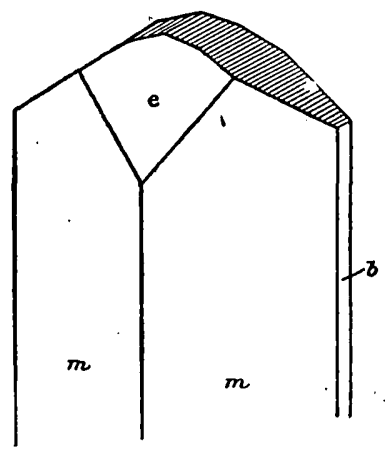

FIG, 11.-Glaucodot. especially in the pyritohedral zone. The faces are for the most part not striated and give excellent reflections. In size the crystals reach a maximum of about one-half centimeter in diameter. They were so closely erowded together that only a small portion of each crystal was developed; consequently, when the group was broken, a few fragments showed only one or two zones of faces. 
Twenty-five forms are present on the twelve crystals measured. They are:

$$
\begin{aligned}
c & =100 \\
A & =1.10 .0 \\
\mathrm{~b} & =180 \\
f & =140 \\
a & =130 \\
e & =120 \\
B & =590
\end{aligned}
$$

$$
\begin{aligned}
& \delta=450 \\
& \xi=560 \\
& \gamma=670 \\
& d=110 \\
& K=114 \\
& m=113
\end{aligned}
$$

\begin{tabular}{|c|c|c|c|c|c|c|c|c|c|c|}
\hline \multirow{2}{*}{ No. } & \multirow{2}{*}{ Letter. } & \multirow{2}{*}{ Symbol. } & \multicolumn{4}{|c|}{ Measured. } & \multicolumn{4}{|c|}{ Calculated. } \\
\hline & & & \multicolumn{2}{|c|}{$\phi$} & \multicolumn{2}{|c|}{ p. } & \multicolumn{2}{|c|}{$\phi$} & \multicolumn{2}{|c|}{$\rho$. } \\
\hline & & & $\circ$ & & 。 & & 。 & & & \\
\hline 1 & $c$ & 100 & 90 & 00 & 90 & 00 & 90 & 00 & 90 & 00 \\
\hline 2 & $A$ & 1.10 .0 & 5 & 49 & 90 & 00 & 5 & 43 & 90 & 00 \\
\hline 3 & b & 180 & 7 & 08 & 90 & 00 & 7 & 08 & 90 & 00 \\
\hline 4 & $f$ & 140 & 14 & 03 & 90 & 00 & 14 & 02 & 90 & 00 \\
\hline 5 & $a$ & 130 & 19 & 06 & 90 & 00 & 18 & 26 & 90 & 00 \\
\hline 6 & $e$ & 120 & 26 & 34 & 90 & 00 & 26 & 34 & 90 & 00 \\
\hline 7 & $B$ & 590 & 28 & 59 & 90 & 00 & 29 & 03 & 90 & 00 \\
\hline 8 & $\alpha$ & 470 & 29 & 30 & 90 & 00 & 29 & 45 & 90 & 00 \\
\hline 9 & $h$ & 350 & 31 & 04 & 90 & 00 & 30 & 58 & 90 & 00 \\
\hline 10 & $C$ & 580 & 31 & 59 & 90 & 00 & 32 & 00 & 90 & 00 \\
\hline 11 & $D$ & 570 & 35 & 17 & 90 & 00 & 35 & 32 & 90 & 00 \\
\hline 12 & $i$ & 340 & 36 & 5 ? & 90 & 00 & 36 & 52 & 90 & 00 \\
\hline 13 & $E$ & 790 & 37 & 47 & 90 & 00 & 37 & 52 & 90 & 00 \\
\hline 14 & $\delta$ & 450 & 38 & 39 & 90 & 00 & 38 & 39 & 90 & 00 \\
\hline 15 & $\xi$ & 560 & 39 & 48 & 90 & 00 & 39 & 48 & 90 & 00 \\
\hline 16 & $\gamma$ & 670 & 40 & 36 & 90 & 00 & 40 & 36 & 90 & 00 \\
\hline 17 & $d$ & 110 & 45 & 00 & 90 & 00 & 45 & 00 & 90 & 00 \\
\hline 18 & $K$ & 114 & 45 & 00 & 19 & 25 & 45 & 00 & 19 & 28 \\
\hline 19 & $m$ & 131. & 18 & 33 & 72 & 45 & 18 & 26 & 72 & 27 \\
\hline \multirow{2}{*}{20} & \multirow[b]{2}{*}{$q$} & 112 & 26 & 34 & 65 & 54 & 26 & 34 & 65 & 54 \\
\hline & & 121 & 44 & 59 & 35 & 15 & 45 & 00 & 35 & 16 \\
\hline 21 & 0 & 111 & 45 & 00 & 54 & 44 & 45 & 00 & 54 & 44 \\
\hline \multirow{3}{*}{22} & \multirow{3}{*}{$u$} & 122 & 45 & 00 & 70 & 31 & 45 & 00 & 70 & 31 \\
\hline & & 221 & 26 & 34 & 48 & 13 & 26 & 34 & 48 & 11. \\
\hline & & 123 & 26 & 35 & 36 & 40 & 。26 & 34 & 36 & 42 \\
\hline \multirow[t]{2}{*}{23} & $x$ & 1.32 & 18 & 31 & 57 & 40 & 18 & 26 & 57 & 41 \\
\hline & & 231 & 33 & 42 & 74 & 30 & 33 & 41 & 74 & 30 \\
\hline 24 & $\psi$ & 124 & 26 & 20 & 28 & 40 & 26 & 34 & 29 & 1.2 \\
\hline 25 & $\omega$ & 134 & 18 & 18 & 39 & 37 & 18 & 26 & 38 & 19 \\
\hline
\end{tabular}

$q=112$

$0=111$

$u=221$

$x=123$

$\psi=1.24$

$\omega=134$

The average of the angles measured with the calculated angles are shown in the following table: 
Of the pyritohedrons $i$ is the dominant form and is always well developed in large broad faces. $e, \delta, \xi, \gamma$ occur quite frequently as smaller faces, while $\mathrm{b}, f, a, \alpha, h$, are rarely present as very narrow faces. $c$ is also harrow but never striated, always giving perfect reflections. The dodecahedron, $d$, is usually somewhat uneven. The octahedron, $o$, and $q, u$, and $x$ occur commonly, while $k, m, \psi, \omega_{0}$ were observed but once each.

\section{VANADINITE.}

A specimen of vanadinite, doubtless from Yuma County, Ariz., shows, a few crystals that possess a large number of forms. The crystals are $3 \mathrm{~mm}$. long and $2 \mathrm{~mm}$. thick, and present the usual appearance and habit of vanadinite. The zone $c \mathrm{~m}$ is, however, very rich in forms. A number of vicinal forms were encountered that seem characteristic of the particular specimen. Sometimes the crystals are broken, or an apparently simple crystal may be composed of several ones not strictly in parallel position. In such cases, each zone $c m$ was carefully adjusted by itself and the angles were measured. A continuous line of signals was practically never encountered, each face being distinct and giving a sharp signal.

The forms observed are quoted below.

\begin{tabular}{|c|c|c|}
\hline Known forms: & Known forms-Continued. & New forms-Continued. \\
\hline$\grave{c}=0001$ & $z=30 \overline{3} 1$ & $K=11.0 . \overline{1} \overline{1} .3$ \\
\hline$a=10 \overline{1} 0$ & $\pi=40 \overline{4} 1$. & $I=10.0 . \overline{1} \overline{0} .1$ \\
\hline$b=11 \overline{2} 0$ & $s=11 \overline{2} 1$ & Vicinal forms: \\
\hline$h=21 \overline{3} 0$ & $v=11 \overline{2} 2$ & $26.0 . \overline{2} \overline{6} .25$ \\
\hline$g=31 \overline{4} 0$ & $i=21 \overline{3} 1$ & $43.0 . \overline{4} \overline{3} .40$ \\
\hline$\sigma=10 \overline{1} 3$ & $\xi=41 \overline{5} 4$ & $19.0 . \overline{1} \overline{9} .10$ \\
\hline$r=10 \overline{1} 2$ & $l=32 \overline{5} 2$ & $15.0 . \overline{1} \overline{5} .7$ \\
\hline$x=10 \overline{1} 1$ & New forms: & Doubtful forms: \\
\hline$\delta=50 \overline{5} 4$ & $d=53 \overline{8} 0$ & $n=11.0 . \overline{1} 1.10$ \\
\hline$y=40 \overline{4} 3$ & $k=30 \overline{3} 4$ & $B=90 \overline{9} 5$ \\
\hline$x=30 \overline{3} 2$ & $o=70 \overline{7} 6$ & $D=90 \overline{9} 4$ \\
\hline$\beta=50 \overline{5} 3$ & $u=70 \overline{7} \overline{5}$ & $\mathrm{E}=80 \overline{8} 3$ \\
\hline$y=20 \overline{2} 1$ & $A=70 \overline{7} 4$ & $\mathrm{G}=10.0 . \overline{10} .3$ \\
\hline$q=50 \overline{5} 2$ & $H=70 \overline{7} 2$ & $\dot{\mathrm{F}}=11.0 . \overline{1} \mathrm{1} .4$ \\
\hline
\end{tabular}


The measured and calculated angles for all these forms are:

\begin{tabular}{|c|c|c|c|c|c|c|c|c|c|c|}
\hline \multirow{2}{*}{ No. } & \multirow{2}{*}{ Letter. } & \multirow{2}{*}{$\frac{\text { Symbol. }}{\text { Miller. }}$} & \multicolumn{4}{|c|}{ Measured. } & \multicolumn{4}{|c|}{ Calculated. } \\
\hline & & & $\phi$. & & $\rho$. & & $\phi$ & & & . \\
\hline & & & $\circ$ & & & & 。 & , & 0 & , \\
\hline 1 & $c$ & 0001 & ... & $\because$ & & 00 & $\ldots$ & $\ldots$ & 0 & 00 \\
\hline 2 & $a$ & $10 \overline{1} 0$ & 0 & 00 & 90 & 00 & 0 & 00 & 90 & 00 \\
\hline 3 & $b$ & $11 \overline{2} 0$ & 30 & 00 & 90 & 00 & 30 & 00 & 90 & 00 \\
\hline 4 & $h$ & $21 \overline{3} 0$ & 19 & 09 & 90 & 00 & 19 & 06 & 90 & 00 \\
\hline 5 & $g$ & $\dot{3} 1 \overline{4} 0$ & 13 & 54 & 90 & 00 & 13 & 54 & 90 & 00 \\
\hline 6 & $d$ & $53 \overline{8} 0$ & 21 & 34 & 90 & 00 & 21 & 47 & 90 & 00 \\
\hline 7 & $\sigma$ & $10 \overline{1} 3$ & .0 & 00 & 15 & 23 & 0 & 00 & 15 & 20 \\
\hline 8 & $r$ & $10 \overline{1} 2$ & 0 & 00 & 22 & 22 & 0 & 00 & 22 & 21 \\
\hline 9 & $k$ & $30 \overline{3} 4$ & 0 & 00 & 31. & 44 & 0 & 00 & 31 & 40 \\
\hline 10 & $x$ & $10 \overline{1} 1$ & 0 & 00 & 39 & 29 & 0 & 00 & 39 & 26 \\
\hline 11 & - & $26.0 . \overline{2} \overline{6} .25$ & 0 & 00 & 40 & 26 & 0 & 00 & 40 & 32 \\
\hline 12 & - & $43.0 . \overline{4} \overline{3} .40$ & 0 . & 00 & 41 & 29 & 0 & 00 & 41 & 29 \\
\hline 13 & $n$ & 11. $0 . \overline{1} \overline{1} .10$ & 0 & 00 & 42 & 16 & 0 & 00 & 42 & 08 \\
\hline 14 & $o$ & $70 \overline{7} 6$ & 0 & 00 & 43 & 54 & 0 & 00 & 43 & 49 \\
\hline 15 & $\delta$ & $50 \overline{5} 4$ & 0 & 00 & .45 & 47 & 0 & 00 & 45 & 47 \\
\hline 16 & $\gamma$ & $40 \overline{4} 3$ & 0 & 00 & 47 & 37 & 0 & 00 & 47 & 38 \\
\hline 17 & $u$ & $70 \overline{7} 5$ & 0 & 00 & 49 & 05 & 0 & 00 & 49 & 01 \\
\hline 18 & $\alpha$ & $30 \overline{3} 2$ & 0 & 00 & 50 & 53 & 0 & 00 & 50 & 58 \\
\hline 19 & $\beta$ & $50 \overline{5} 3$ & 0 & 00 & 54 & 02 & 0 & 00 & 53 & 53 \\
\hline 20 & $A$ & $70 \overline{7} 4$ & 0 & 00 & 55 & 13 & 0 & 00 & 55 & 12 \\
\hline 21 & $B$ & $90 \overline{9} 5$ & 0 & 00 & 56 & 09 & 0 & 00 & 55 & 57 \\
\hline 22 & - & 19. 0. $\overline{1} \overline{9} .10$ & 0 & 00 & 57 & 24 & 0 & 00 & 57 & 23 \\
\hline 23 & $y$ & $20 \overline{2} 1$ & 0 & 00 & 58 & 42 & 0 & 00 & 58 & 42 \\
\hline 24 & - & 15. $0 . \overline{1} \overline{5} .7$ & 0 & 00 & 60 & 25 & 0 & 00 & 60 & 25 \\
\hline 25 & $D$ & $90 \overline{9} 4$ & 0 & 00 & 61 & 42 & 0 & 00 & 61 & 37 \\
\hline 26 & $q$ & $50 \overline{5} 2$ & 0 & 00 & 63 & 43 & 0 & 00 & 64 & 03 \\
\hline 27 & $E$ & $80 \overline{8} 3$ & 0 & 00 & 65 & 30 & 0 & 00 & 65 & 29 \\
\hline 28 & $F$ & 11. $0 . \overline{1} \mathrm{1} .4$ & 0 & 00 & 66 & 10 & 0 & 00 & 66 & 09 \\
\hline 29 & $\zeta$ & $30 \overline{3} 1$ & 0. & 00 & 67 & 52 & 0 & 00 & 67 & 56 \\
\hline 30 & $G$ & $10.0 . \overline{1} \overline{0} .3$ & 0 & 00 & 69 & 53 & 0 & 00 & 69 & 57 \\
\hline 31 & $H$ & $70 \overline{\overline{7}} 2$ & 0 & 00 & 70 & 57 & 0 & 00 & 70 & 50 \\
\hline 32 & $K$ & - 11.0.11. 3 & 0 & 00 & 71 & 38 & 0 & 00 & 71 & 39 \\
\hline 33 & $\pi$ & $40 \overline{4} 1$ & 0 & 00 & 73 & 04 & 0 & 00 & 73 & 05 \\
\hline 34 & $L$ & 10. 0. $\overline{1} \overline{0} .1$ & 0 & 00 & 83 & 09 & 0 & 00 & 83 & 04 \\
\hline 35 & $s$ & $11 \overline{2} 1$ & 30 & 15 & 54 & 40 & 30 & 00 & 54 & 55 \\
\hline 36 & $v$ & $11 \overline{2} 2$ & 29 . & 54 & 35 & 22 & 30 & 00 & 35 & 27 \\
\hline 37 & $i$ & $21 \overline{3} 1$ & 19 & 02 & 65 & 11 & 19 & 06 & 65 & 19 \\
\hline 38 & $\xi$, & $41 \overline{5} 4$ & 10 & 56 & 41 & 49 & 10 & 53 & 43 & 17 \\
\hline 39 & $l$ & $39 \overline{5} 2$ & 20 & 38 & 60 & 03 & 23 & 25 & 60 & 50 \\
\hline
\end{tabular}


Following is a short description of the new forms, the $\rho$ angle only being given for the pyramids, $\phi$ being $0^{\circ} 00^{\prime}$.

$d=\{53 \overline{8} 0\}$ : Four faces of. this new prism were noted, always as line faces.

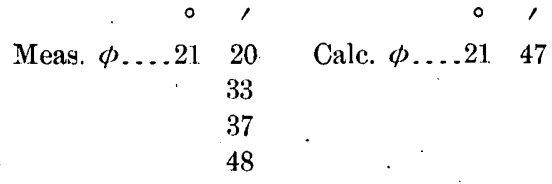

$k=\{30 \overline{3} 4\}:$ Only two faces of this form are present, both on the same crystal. The faces, though narrow, are broader than many of the others, and gave fairly good reflections.

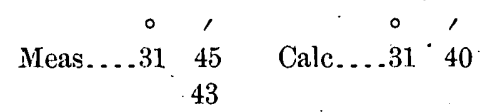

$\{26.0 . \overline{2} \overline{6} .25\}$ : This and the following form are doubtless vicinal to $\{10 \overline{1} 1\}$, though they both occur a number of times. This one is present on four crystals, and the measurements show the following values:

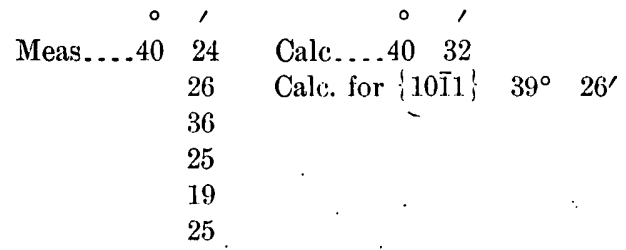

$\{43.0 . \overline{3} 3.40\}$ : This vicinal form is present on three crystals and occurs nine times. The faces are small and the reflections fair.

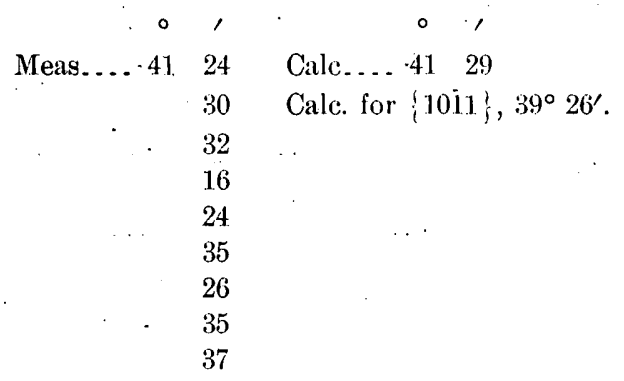

$n=\{11 \cdot 0 . \overline{1} 1 \cdot 10\}:$ This form occurs on two crystals. The faces are narrow and the reflections but fair.

$$
\begin{array}{lrrrr}
\text { Meas.... } & 42 & 24 & \text { Calc.... } 42 & 08 \\
& 20 & & & \\
& 04 & &
\end{array} .
$$

The form can be only classed as doubtful. 
$o=\{70 \overline{7} 6\}$ : Occurring on three crystals, the following angles were measured:

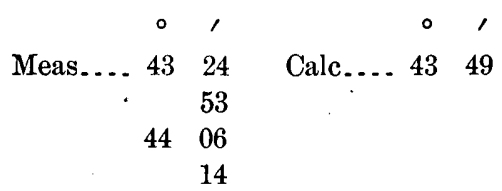

$u=\{70 \overline{7} 5\}:$ The reflections from the very nariow faces of this form were poor.

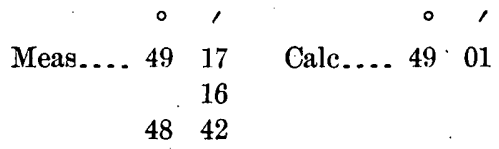

$A=\{7074\}:$ This is the most prominent of the new forms, and occurs ten times as (relatively) broad faces on four crystals. The reflections were usually fairly good.

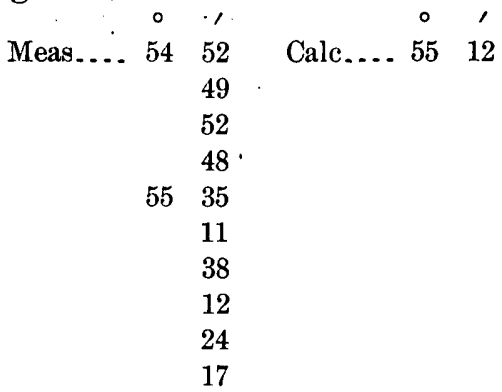

$B=\{90 \overline{9} 5\}:$ A very doubtful form, present as very narrow faces giving poor reflections.

$$
\text { Meas.... } 56 \quad \begin{array}{lllll}
56 & 18 & \text { Calc..... } & 55 & 57
\end{array}
$$

$\{19.0 . \overline{1} \overline{9} .10\}$ : Another vicinal form, doubtless vicinal to $\{20 \overline{2} 1\}$.

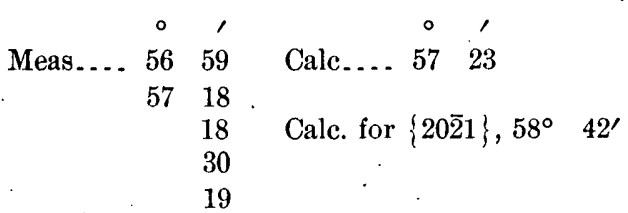

$C=\{15.0 . \overline{15} .7\}:$ Another vicinal form occurring on three crystals.

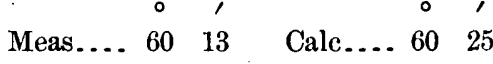

$$
\begin{aligned}
& 38
\end{aligned}
$$

$D=\{90 \bar{\theta} 4\}:$ A doubtful form present on one crystal.

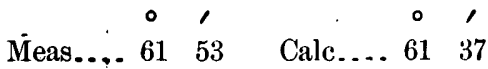

$$
\begin{aligned}
& 30
\end{aligned}
$$


$E=\{80 \overline{8} 3\}:$ A very doubtful form.

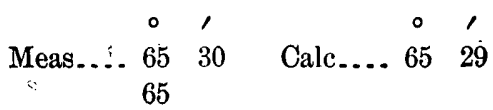

$F=\{11 \cdot 0 . \overline{1} \overline{1}: 4\}:$ A doubtful form.

$$
\text { Meas.... } 66 \quad 01 \quad \text { Calc.... } 66 \quad 06
$$

$G=\{10 \cdot 0 \cdot \overline{1} \overline{0} \cdot 3\}:$ A doubtful form.

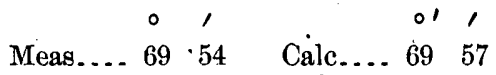

$I=\{70 \overline{7} 2\}$ : Though occurring but once as a small face, it gave a fairly good reflection.

$$
\text { Meas.... } 70 \quad 57 \quad \text { Calc.... } 70 \quad 50
$$

$K=\{11 \cdot 0 . \overline{1} 1.3\}:$ Two faces of this form were noted.

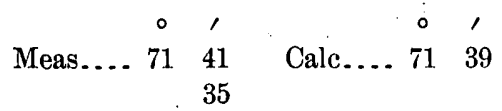

$L=\{10 \cdot 0 \cdot \overline{1} \overline{0} \cdot 1\}:$ Two faces of this form are present on one crystal.

$$
\text { Meas.... } \begin{array}{rrrr}
82 & 56 & \text { Calc....-83 } & 04 \\
83 & 21
\end{array}
$$

The average value obtained for $p_{0}$ is 0.8223 .

\section{GLOBULAR IEPIDOLITE.}

Text-books on mineralogy do not mention the globular form for the lithia-mica lepidolite. Such globular forms have long been known for muscovite, and in fact are by no means uncommon for that speries. While studying the literature of lepidolite in general two occasions were noted in which globular lepidolite was spoken of.

One was by vom Rath ${ }^{a}$ in describing the litbia deposits of the island of Elba. On page 649 he says: "Zuweilen sind die (lepidolite) Blätter zu Kugeln gruppirt"-at times the (lepidolite) plates are grouped in spheres (=globular).

The second mention was found in Hamlin's ${ }^{b}$ book on Mount Mica, Paris, Me., in which he says:

On November 20,1822 , E. L. Hamlin sent to Professor Silliman, at Yale College, a box of minerals from the locality, with letters and catalogue as follows: * * *. In the catalogue Mr. Hamlin mentions lilac-colored mica as found in small globular concretions.

A large specimen of the pegmatite rock in front of Mr. Bowker's barn, at Mount Mica, shows a number of these spheres of lepidolite, 
several centimeters in diameter. At Auburn, Me., several specimens of globular lepidolite were found in the summer of 1904 by Mr. Wade, working on Pulcifer's ledge on Mount Apatite. Some of these were fairly large, one such specimen (by no means the largest) collected by the writer being $6 \mathrm{~cm}$. in diameter and $2 \frac{1}{2} \mathrm{~cm}$. thick. Here, at Mount Apatite, this globular form of lepidolite is abundant and forms one of its characteristic phases. It often has a whitish border (a few millimeters thick) of some undetermined mineral (próbably a mica) surrounding it.

\section{20. LIBETHENITE.}

Some minute crystals of libethenite, about a millimeter in diameter, from Yerington, Lyon County, Nev., proved to be well adapted for measurement. As the symmetry of the mineral has been regarded as orthorhombic by some writers and monoclinic by others, it was hoped that the measurement of these crystals might contribute something to the question. The results have been very satisfactory and show that the crystals measured are orthorhombic and not monoclinic.

The crystals were collected by Mr. D. Smith, to whom the writer is under obligations for the material investigated. Qualitative chemical tests showed the presence of copper, phosphoric acid, and water.

Some time after these measurements were made an article by Melczer $^{a}$ appeared on the symmetry and form of libethenite, in which he came to the same conclusion as the writer in regard to the symmetry of the mineral, his conclusion being based on a large number of measurements of Cornwall crystals. There can therefore hardly be any more question as to the orthorhombic character of libethenite.

The crystals measured are minute, less than a millimeter in diameter, but well formed, and the faces usually give very good and sharp signals. As the unit prism is present on all crystals; they were easily adjusted in true polar position and could be quickly and accurately measured with the two-circle goniometer.

Under the microscope the crystals always extinguish parallel to the crystallographic axes. No phenomena, such as twinning structure or twinning lamellæ, could be observed, either under the microscope or on the goniometer.

Seven of the most perfect crystals were removed from the matrix and measured. The forms observed are: $b=\{010\}, m=\{110\},{ }^{*} h=\{540\}$, $\delta=\{310\},{ }^{*} l=\{410\}, e=\{011\}, d=\{101\},\{s=111\}$. . 
The angles measured and calculated ${ }^{a}$ for the eight forms given are:

\begin{tabular}{|c|c|c|c|c|c|c|c|c|c|c|}
\hline \multirow{2}{*}{ No. } & \multirow{2}{*}{ Letter. } & Symbol. & \multicolumn{4}{|c|}{ Measured. } & \multicolumn{4}{|c|}{ Calculated. } \\
\hline & & Miller. & $\phi$. & & p. & & $\phi$ & & & . \\
\hline & & & & & $\circ$ & ' & 。 & & $\circ$ & ' \\
\hline 1 & $b$ & 010 . & 0 & 01 & 90 & 00 & 0 & 00 & 90 & 00 \\
\hline 2 & $m$ & 110 & 46 & 11 & 90 & 00 & 46 & 10 & 90 & 00 \\
\hline 3 & $h$ & 540 & 52 & 26 & 90 & 00 . & 52 & 28 & 90 & 00 \\
\hline 4 & $\delta$ & 310 & 71 & 46 & 90 & 00 & 72 & 15 & 90 & 00 \\
\hline 5 & $l$ & 410 & 77 & 02 & 90 & 00 & 76 & 30 & 90 & 00 \\
\hline 6 & $e$ & 0.11 & 0 & 00 & 35 & 03 & 0 & 00 & 35 & 04 \\
\hline 7 & $d$ & 101 & 89 & 56 & 36 & 11 & 90 & 00 & 36 & 10 \\
\hline 8 & $s$ & 111 & 46 & 11 & 45 & 22 & 46 & 10 & 45 & 23 \\
\hline
\end{tabular}

Besides these the prism $t=\{210\}$ seems to be present on one crystal, though the reflection was very poor and the measured angle varies several degrees from the calculated value.

Measured $(\phi), 61^{\circ} 55^{\prime}$, calculated $(\phi)$, $64^{\circ} 21^{\prime}$.

The new prism $h=\{540\}$ occurs but once, giving a fair reflection.

The new prism $l=\{410\}$ occurs five times, once as a broad face and the other times as a narrow face.

Goldschmidt does not give the form $d=\{101\}$ in his Winkeltabellen, but Melc-. zer gives the form as present on his

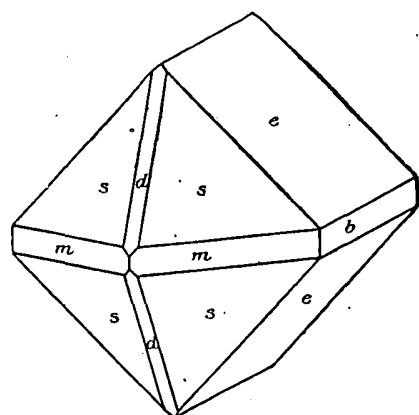

Fig. 12.-Libethenite. crystals, and it also occurs as long, narrow faces on the crystals measured by the writer.

In habit the crystals differ somewhat from that shown in Dana's system, inasmuch as on the Nevada crystals the pyramid $s$ is large, equal in size to the brachydome, thus making the prism faces subordinate in size. The general appearance of these crystals is shown in fig. 12. 
The combinations observed are shown in the following table:

\begin{tabular}{|c|cccccccc|}
\hline $\begin{array}{c}\text { Crysta1 } \\
\text { No. }\end{array}$ & $b$ & $m$ & $h$ & $\delta$ & $l$ & $e$ & $d$ & $s$ \\
\hline 1 & - & $m$ & - & - & - & $e$ & - & $s$ \\
2 & $b$ & $m$ & - & - & - & $e$ & - & $s$ \\
3 & $b$ & $m$ & - & $\delta$ & $l$ & $e$ & $d$ & $s$ \\
4 & $b$ & $m$ & - & - & - & $e$ & $d$ & $s$ \\
5 & $b$ & $m$ & - & - & $l$ & $e$ & $d$ & $s$ \\
6 & $b$ & $m$ & - & - & - & $e$ & - & $s$ \\
7 & $b$ & $m$ & $h$ & - & $l$ & $e$ & - & $s$ \\
\hline
\end{tabular}

From all the good measurements, 27 values for $p_{o}$ and 24 values for $q_{0}$ were calculated, the average values being

$$
\begin{aligned}
& \mathrm{p}_{\mathrm{o}}=.7308 \\
& \mathrm{q}_{\mathrm{o}}=.7014
\end{aligned}
$$

which agree very closely with those given by Goldschmidt, namely:

$$
\begin{aligned}
& \mathrm{p}_{\mathrm{o}}=.7311 \\
& \mathrm{q}_{\mathrm{o}}=.7019 .
\end{aligned}
$$

\begin{tabular}{|c|c|c|c|}
\hline \multicolumn{2}{|c|}{$\mathrm{p}_{0}$} & \multicolumn{2}{|c|}{$q_{0}}$. \\
\hline Values. : & $\begin{array}{c}\text { Measure- } \\
\text { ments. }\end{array}$ & Valueş. & $\begin{array}{c}\text { Mensure } \\
\text { ments. }\end{array}$ \\
\hline .7295 & 2 & .6993 & 2 \\
\hline .7297 & 2 & .7002 & 3 \\
\hline .7301 & 1 & .7004 & 2 \\
\hline .7302 & 1 & .7005 & 1 \\
\hline .7303 & 3 & .7010 & 1 \\
\hline .7304 & 3 & .7011 & 3 \\
\hline .7305 & 1 & .7014 & 1 \\
\hline .7308 & 1 & .7016 & 1 \\
\hline .7309 & 1 & .7018 & 2 \\
\hline .7312 & 3 & .7021 & 1 \\
\hline .7314 & 2 & .7022 & 2 \\
\hline .7316 & 3 & .7026 & 2 \\
\hline .7319 & 2 & .7028 & 2 \\
\hline .7321 & 2 & .7034 & 1 \\
\hline Av., . 7308 & 27 & Av., . 7014 & 24 \\
\hline
\end{tabular}

The values obtained for $p_{o}$ and $q_{o}$ are às follows: 
The difference in the $\phi$ and $\rho$ angles, for the forms, calculated from the two values, differ not more than a minute.

The average value obtained by Melczer is

$$
\begin{aligned}
& \mathrm{p}_{\mathrm{o}}=.7309 \\
& \mathrm{q}_{\mathrm{o}}=.7027 .
\end{aligned}
$$

Taking the average of all three sets of values, we have

\begin{tabular}{|r|r|}
\hline \multicolumn{1}{|c|}{$\mathrm{p}_{\mathrm{o} .}$} & \multicolumn{1}{c|}{$\mathrm{q}_{0 \cdot}$} \\
\hline .7308 & .7014 \\
.7311 & .7019 \\
.7309 & .7027 \\
\hline Av., .7309 & Av., .7020 \\
\hline
\end{tabular}

The axial ratio for libethenite then becomes

$$
\mathrm{a}: \mathrm{b}: \mathrm{c}=.9605: 1: .7020 \text {. }
$$

\section{CRYSTALLOGRAPHY OF LEPIDOLITE.}

A group of lepidolite crystals was collected by the writer in the summer of 1904 at a gem mine about 4 miles east of Ramona, on the stage road from Ramona to Julian, San Diego County, Cal. The mine was opened and worked for its gems, such as topaz, tourmaline, garnet, etc. With these are associated quartz, orthoclase in good crystals at times several feet long, muscovitè, and, rarely, lepidolite. The minerals in question all occur in the loose dirt, filling "pockets" in a pegmatite dike.

The specimen of lepidolite under consideration consists of a group of intergrown crystals which often reach large size. The group itself is about $5 \mathrm{~cm}$. thick and the individual crystals measure about $1 \mathrm{~cm}$. across the base, though crystals with a diameter of $2 \mathrm{~cm}$. are not rare. The crystals are also proportionally thick, the average being from 2 to $4 \mathrm{~mm}$., though a few are somewhat thicker. They are transparent and of a very pale pink color, and, in the direction normal to the vertical axis and parallel to the base, of a slightly deeper tint. , They fuse casily to a white enamel, coloring the flame an intense crimson. The side faces are usually plane, not rounded nor striated, and of a brilliant polish, giving excellent signals. It is, however, extremely difficult to secure a complete crystal from the group owing to the perfect basal cleavage, which will cause a crystal to split into a number of layers. This will also at times cause part of a crystal to become slightly displaced. In consequence of this difficulty most of the crystals measured are only parts of the original crystals, and two such pieces 
measured as separate crystals may, in reality, be parts of one and the same crystal.

As may be expected, the crystals of lepidolite are similar to those of muscovite. They also show; however, some marked differences. The interfacial angles are nearly the same and the crystals are naturally referred to the same axes as muscovite. There are three marked differences between these crystals and those of muscovite: (1) The rarity of twins, only one being found in twenty-one crystals; (2) the absence of the characteristic face of muscovite, $M=\{221\}$; and (3) the presence of the $a$ face $\{100\}$, occurring on 10 out of 21 crystals. The crystals are not so striated as the green North Carolina muscovites, for instance, and in many cases the faces yielded perfect signals.

The common forms are $c=\{001\}, b=\{010\}, a=\{100\}, e=\{023\}$, $o=\{112\}, \mu=\{\overline{1} 11\}$, and $x=\{\overline{1} 31\}$. Besides these the following have been determined: $N=\{261\}, z=\{132\}, l=\{130\}$, and possibly several others, as $\{\overline{2} 23\},\{\overline{2} 21\},\{\overline{1} 12\}$; also a number of forms which occur for the most part as broad faces, giving good reflections, but having anomalous indices, and which need further study.

The most frequent combination is $c b o u x$, after which comes $c b o$ $u x$ e $a$. Whenever the angle (001): (010) could be accurately measured it was found to be exactly $90^{\circ} 00^{\prime}$ in every case, and the distribution of the faces also indicates monoclinic symmetry.

It was noticed that the angle between the same forms varied slightly on different crystals. The faces were smooth and highly polished, and the angles could easily be measured with an error not greater than $\mathbf{1}^{\prime}$. It is suggested that this variation is real, and is due to the fact that lepidolite is an isomorphous mixture of two end products, and as the ratio of these two products varies, the crystallographic and physical properties of the mineral also vary. Further study on the possible correlation of the various properties of the mineral is under way.

This lepidolite belongs to the "second class" of Tschermak or the "brachydiagonal class" of Scharizer-i. e.; the axial plane is parallel to the clinopinacoid and not normal to it. The trace of the axial plane was always parallel to one arm of the percussion figure.

The above is only a brief preliminary statement. . The detailed crystallography of the mineral will soon be published in a paper on the mineralogy of this entire fiekü of lithium minerals in southern California.

The writer's thanks are due Mr. Dan McIntosh, jr., of Ramona, the owner of the mine. 


\section{IN D EX.}

Egirite................................. Page.
Alaska, minerals from $\ldots \ldots \ldots \ldots \ldots \ldots \ldots . .129-131$
Alibegoff, G., cited, on separation of ura-

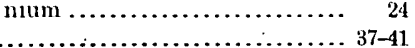

Alunite.......................... 37-41

Alunite-jarosite group $\ldots \ldots \ldots \ldots \ldots \ldots \ldots \ldots . . \ldots \ldots$

Amblygonite ....................... 122

Analeite....................... $76-79$

Andulusitic rock .................. 105, 106

Anhydrite ........................ 132

A pophyllite ........................ 126

Argentina, dumortierite from .........94,118

Arizona Central mine ................. 49-51

Arizona Copper Company ............. 47-53

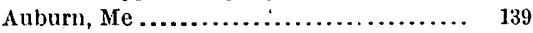

Austria, dumortierite from.............. 93-94

Beaunan, France..................... 92

Becker, G. F., letter of transmittul........ 5

Benedicks, C., on thalénite and yttrialite.. 61-63

Bergen Hill, N. J ............... 85-87, 89-90

Bertrnnd, E., on dumortierite.... 91, 113,119, 120

Big Bug district, Ariz ................. 132

Blue Mountain district, Utah ........... 11

Bogg's mine, A riz ...................... 132

Bohemia, dumortierite from ........... 93

Boleo, Mexico ...................... 48

Bon Ton mines, Ariz ................ 46

Boothite......................... 122-123

Bournonite ....................... 132

Boutwell, J. M., willemite crystals....... 46

Branchville, Conu .................. 121

Braun, F., on dumortierite localities...... 95

Brignuis, France ..................... 92

Brochuntite ..................... 52

Buxton mines, S. Dak .................. 37

Culımine........................ 46

Californite $\ldots \ldots \ldots \ldots \ldots \ldots \ldots \ldots \ldots \ldots \ldots .72-74$

Campo Seco, Cal .................... 123

Carnotite........................ 9-31

Cassiterite .......................... 129-131

Cassiterite Creek, Aluska. . . . . . . . . . . . . . 129-131

Chubuzite ............................ 81-84

Chalcocite..........................45-46;

Chuponost, France ................... 91

Chase Creek, Ariz ................ 46-47,53-54

Chromium........................ 14,21

Chrysocolla......................... 47-48

Church, A. H., cited, on silver phillipsite.. 75

Clarke, F. W., on gyrolite .............. 125

on pseudo-serpentine............. 69-71

on tiromsonite................... 73

on vesuvianite.................. 73

prefatory note.

\begin{tabular}{r|l}
73 & Gounard, F., on dum \\
$7-8$ & Grand Manan, N. B
\end{tabular}
Page.

Clarke, F. W., and Steiger, George, cited... . 75 on californite.................... 72-74

Clifton district, A riz................ 45

Clifton-Morenci district, A riz .......... 42

Clip, Ariz....................... 95, 106

Collier, A. J., on zinnwaldite... . . . . . . . 129-130

Cooks Peak, N. Mex............. 32, 34, 35, 36

Copper Mountain mine, Ariz........... 52

Copper Prince clnim, Colo ............. 24-29

Copper Queen mine, Ariz.............. $\quad{ }_{52}$

Copper-pitch ore ................. 48,49

Cornwall, England, minerals from.... 53, 140, 141

Coronadite ......................... 42-45

Coronado mine, Ariz ............. 42,48,51

Corundum...................... 39

Cripple Creek, Colo.............. 55, 56, 126

Cross, W., on almite ............... 37

Cumenge, E., and Friedel, C., on carnotite. 9,

$22-24,28-29$

Curie, M. and Mme., on earnotite....... 9,26 Cyanite............................ 96

Damour, A. A., on dumortierite... 91, 93, 113, 120 Dana, E. S., cited........... 51, 111, 125, 127, 128 Dehes $n$, C $n$........................ 96

Detroit mine, Ariz................ 48,49

Diller, J. S., on pseudo-serpentine........ 70

Diller, J. S., and Riggs, R. B., on dumortierite $\ldots \ldots \ldots \ldots \ldots \ldots \ldots \ldots \ldots .91,120$

Dioptase. . ................... 46,47

Duling, J. R ...................... 16

Dumortier, $\mathrm{E} \ldots \ldots \ldots \ldots \ldots \ldots \ldots \ldots \ldots \ldots \ldots$

Dumorticrite ....................... 91-120

Eakle, A. S., on pectolite............. 124

Elacolite ......................... 90

Emmonsite ....................... 55-56

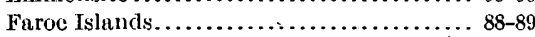

Ferric tellurites .................... 56

Ford, W. E., on dumortierite.......... 91,

$96,102,114,116,117,120$

Fort Point, Cal ................... 125, 126

Foullnn, H. von, cited ............... 24

Frenzel,.. B ........................ 12

Friedel, C., and Cumenge, E., on carnotite. 9 ,

Gerfield Gulch, Ariz....

Garnet......................... 72,73

Gerhardtite..................... 53,51

Germany, dumortierite from. 91, 93, 94, 112, 113,118

Glaucodot ......................... 132-133

Goldschmidt, V., cited ... 110,111, 127, 128, 141, 142

Bull. $262-05-10$ 
Page.

Gyrolite

Halloysite

Hamlin, A. C., cited.................. 139

Harlem, N. Y...................... 94

Headden, W. P., cjted................. 37

Heddle, M. F., cited ................. 125, 126

Heighway, A. E., eited............... 72

Hematite........................ 39

Herz, W., cited . . . ................... 124

Heumann, K., cited................. 75

Hidden, W. E., and Mackintosh, J. B., cited.................6 61, $62,64-68$

Hillebrand, W. F., on carnotite and associated minerals............... 18-31

on chromium stains in sandstone.....

on distribution of vanadium ..........

on dumortierite

on kyanite.

on nutrojarosite ................. 33-34

on pisanite ....................... 124

on plumbojarosite................. 36

on roscoelite..................... 11

on tellurium minerals. . . . . . . . . . . . 55-57

on yttrialite and thalenite..........6 61-68

Hillebrand, W. F., and Lindgren, W., on minerals from Arizona ........ 42-54

Hillebrand, W. F., and Penfield, S. L., on alunite-jarosite group ......... 32-41

Hillebrand, W. F., and Ransome, F. L., on carnotite, etc............... 9-31

Hillebrand, W. F., and Schaller, W. T., on lawsonite................. 58-60

Hills, R. C., cited.................... 46

Hintz, $\longrightarrow$, cited ...................... 124

Hornblende ....................... 128, 129

Hurlbut, E. B., cited ................ 37-38

Imligan, Austria .................... 93

Indian Creek, Cal ................... $\quad 72$

Jannasch, P., cited ..................... 118

Jannetaz, E., cited ................ 48

Jarosite. . . . . . . . . . . . . . . . . . . . . $37-41$

Jarosite-alunite group................ 32-41

Jerome mines, A riz................... 54

Jones, H. C., cited.................... 26

Kips Bay, N. Y ...................... 94

Kirghiz Steppes, Russia ................. ' 46

Knight, W. C., cited ................. 56

Koenig, G. A., cited ................. 49

Kohlschüitter, V., cited............... 63

Kunz, G. F., cited .................. $\quad 72$

Kyanite ....................... 96

Lacroix, A.; and Michel-Levy, A., cited ... 113

La Sal Creek, Colo.............. 14, 16, 25, 27

Lawson, A. C., cited ...................... 96

Lawsonite ........................ 58-60

Leona Heights, Cal.................. 123

Lepidolite..................... 139, 140, 143,144

Leucite....................... 79

Libethenite .................... 51, 140-143

Linck, G., cited . ............. 112,113,114,120

Lindgren, W., and Hillebrand, W. F., on minerals from Arizona ....... 42-54

Litchfield, Ne ....................... 90

Longfellow mine, Ariz................ 48

Lyons, France.................. 91,92
Page.

Mammoth mine, Ariz ............... 47

Mackintosh, J. B., and Hidden, W. E., cited $\ldots \ldots \ldots \ldots 661,62,64,65,66,67,68$

Magnet Cove, Ark.................... 90

Melanochalcite..................... 49

Melczer, G., cited ............... 140, 141, 143

Merrill, G. P., cited ..................... 21

Mesolite ........................... 88-89

Metcalf, Ariz ................47,48,52,53

Michel Lévy, A., and Lacroix, A., cited.... 113

Miers, H. A., cited . . . . . . . . . . . . . . 47, 53

Modoc Mountain, Ariz ............... 46

Montezuma mine, Ariz................

Morenci, Ariz................... 45-48,52

Morencite ......................... 49-51

Mount A patite, Me................. 140

Mount Micu, Me..................... 139

Muscovite ....................... 103, 144

Natroalunite ........................ 38-41

Natrojarosite .................. 32-34, 38,40

Natrolite ...................... 86,89

New York, dumortierite from........... 91, $94,95,106,108-112,114,118$

North Carolina, muscovite from ......... 144

Norway, dumortierite from ........... 94, 112

Norway, Me ....................... 121

Oberis, Austria ...................... 93

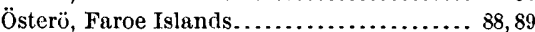

Pala, Cal ....................... 121, 122

Paris, Me ......................... 330

Pectolite......................... 89,90

Penfield, L. S., on dioptase ............ 46,47

on libethenite ................... 51

on spangolite.................. 52

Penfield, S. L., and Hillebrand, W. F., on alunite-jarosite group ....... . . 32-41

Penfield, S. L., and Pirsson, L. V., on willemite .................. 46

Penfield, S. L., and Wells, H. L., on gerhardtite .....................

Pirsson, L. V., and Penfield, S. L., on willemite .................... 46

Pisanite ....................... 123, 124

Placerville, Cal....................... 20

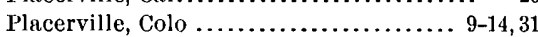

Plumbojarosite.................. 32-41

Porter, J. H., cited ............ 32, 34, 35, 36,41

Poulot, C., cited ................. 9, 10,22

Poulot, .., and Voillequé, cited.......... $\quad 22$

Prehnite........................ 128

Pseudo-serpentine ................. 69-71.

Pyrite ............................... 133-135

Quartz rock..................... 98, 99

Ramona, Cal......................... 143

Ransome, F. L., on lawsonite........... 60

on uranium and vanadium ores....... 10-17

Ransome, F. L., and Hillebrand, W. F., on

carnotite, etc ............. 9-31

Red Mountain, Colo.............. 37-38,40,41

Riggs, R. B., cited............. 91, 114, 118, 120

Riverside Park, N. Y ................... 9

Roc Creek, Colo ........... 9, 16, 24, 25, 27, 28

Romberg, J., cited..................... 94

Roscoelite .................. 11-14, 17, 20

Rosita Hills, Colo .............. $3 i, 3 s, 41$ 
J'age.

Sandstone, green . .................. 18-21

Sundstone, vanadiferous .............. 20

Sin Francisco, Cal ................. 125

San Miguel River, Colo................ 9-14

Schaller, W. T., on dumortierite ........ . . 91-120

on ferric tellurite.................. 55

mineralogical notes ............. 121-144

Schaller, W. T., and Hillebrund, W. F., on lawsonite................. 58-60

Schmiedeberg, Germany ............... 93

Schobrowitz, Austria .................. 93

Scolecite.......................... 87-89

Shannon mine, Ariz.............. 46,52

Shedd, S., on pseudo-serpentine.......... 69

Sierra $A$ bajo district, Utah ............. 11

Silicates, action of silver and thallous nitrutes on .................. 75-90

Sillimanite rocks ................... 97-99

Silver analcite. $\ldots \ldots \ldots \ldots \ldots \ldots \ldots \ldots \ldots \ldots 76,77$

Silver chnbazite $\ldots \ldots \ldots \ldots \ldots \ldots \ldots \ldots .81,82,83,85$

Silver natrolite .................. $85,86,89$

Silver nitrate, action of, on silicutes..... . 75-90

Silver scolecite ................... 87,89

Silver thomsonite $\ldots \ldots \ldots \ldots \ldots \ldots \ldots .79,80,81,85$

Simbad Valley, Colo .................. 14

Smith, W. B., cited.................... 46

Sodu Springs Valley, Nev ............. 32-34

Spangolite...................... 52-53

Spanish Peaks, Colo.................. 133-135

Stundurd Consolidated mine, Oreg....... 132

Stassfurt, Germany.................. $\quad 38$

Steiger, G., analysis of pseudo-serpentine.. $\quad 69$ on sction of silver and thallous nitrates on silicates............ 75-90

Steiger, G., and Clarke, F. W., on "californite" $\ldots \ldots \ldots \ldots \ldots \ldots \ldots \ldots \ldots .72-74$

Stevens mines, $A$ riz $\ldots \ldots \ldots \ldots \ldots \ldots \ldots .46,47$

Stilbite ......................... 84,85

Sumpter, Oreg.................... 132-133

sweden, dumortierite from
Page.

Table Mountain, Colo .............. 76, 79

Tellurite. ........................ 126-128

Tellurium minerals . ......... 55,56,57, 126-128

Terazas mine, Ariz .................. 47

Tetradymite...................... 57

Thalinite......................... 61-68

Thallium andesite.................... 77,78

Thallium chabazite $\ldots \ldots \ldots \ldots \ldots \ldots \ldots .83,84,85$

Thallium leucite ................... $\quad 79$

Thullium mesolite................. 88,89

'.hallium mutrolite .............. 86,87,89

Thallous nitrate, action of, on silientes .... 75-90

Thatcher, R. W., cited............... 69

Thomsonite ...................... 79-81

Topaz ....................... 129-131

Trader, H. B., cited . . . . . ............ 57

Tridymite $\ldots \ldots \ldots \ldots \ldots \ldots \ldots \ldots \ldots \ldots \ldots \ldots, 128, \mathbf{1 2 9}$

Turner, H. W., cited................ 32

Tvedestrand, Norway ................ 94

United States Marble Company, Wash..... 69

Urunium ores...................... 9-31

Vanadiferous minerals.......... 9-31, 135-139

Vanadinite . . . ..................... 135-139

Vanadium ores................. 9-31, 135-139

Vesuvianite $\ldots \ldots \ldots \ldots \ldots \ldots \ldots \ldots \ldots \ldots, 72,73$

Voilleque, —_, and Pculot, C., cited...... 22

Vom Rath, cited.................... 139

Wussons Bluff, N. S................. 81,84

Wells, H. L., and Penfield, S. L., on gerhardtite $\ldots \ldots \ldots \ldots \ldots \ldots \ldots \ldots . \quad 54$

Whale Cove, N. B .................. 87-88

Whitehorn, Colo.................... 57

Whitfield, J. E., cited .............. 114, 118

Willemite $\ldots \ldots \ldots \ldots \ldots \ldots \ldots \ldots \ldots \ldots \ldots \ldots, 46$

W. P. H. mine, Colo ................ 55, 126

Yellow Bird claim, Colo........... 24-29, 30,31

Yellow Boy cluim, Colo ..........24, 25, 27, 28

Yerington, Nev................... 140-143

Yttrialite ....................... $61-68$

Zinmwaldite...................... 129-130 